FERNANDO FERREIRA DE ARAUJO SOUZA

\title{
ANÁLISE DAS INFLUÊNCIAS DAS ESTRATÉGIAS DE DIVERSIFICAÇÃO E DOS MODELOS DE NEGÓCIOS NO DESEMPENHO DAS EMPRESAS DE REAL ESTATE NO PERÍODO 2005 A 2010
}


FERNANDO FERREIRA DE ARAUJO SOUZA

\section{ANÁLISE DAS INFLUÊNCIAS DAS ESTRATÉGIAS DE DIVERSIFICAÇÃO E DOS MODELOS DE NEGÓCIOS NO DESEMPENHO DAS EMPRESAS DE REAL ESTATE NO PERÍODO 2005 A 2010}

Dissertação apresentada à Escola Politécnica da Universidade de São Paulo para obtenção do título de Mestre em Engenharia.

Área de concentração:

Engenharia de construção civil e urbana

Orientador: Prof. Dr. Cláudio Tavares de Alencar 
Este exemplar foi revisado e alterado em relação à versão original, sob responsabilidade única do autor e com a anuência de seu orientador

São Paulo, de dezembro de 2011

Assinatura do autor

Assinatura do orientador

FICHA CATALOGRÁFICA

Souza, Fernando Ferreira de Araújo

Análise das influências das estratégias de diversificação e dos modelos de

negócios no desempenho das empresas de real estate no período 2005 a 2010 / F.F.A. Souza. - ed. rev. -- São Paulo, 2011. $187 \mathrm{p}$.

Dissertação (Mestrado) - Escola Politécnica da Universidade de São Paulo. Departamento de Engenharia de Construção Civil.

1. Construção civil (Desempenho) 2. Empresas I. Universidade de São Paulo. Escola Politécnica. Departamento de Engenharia de Construção Civil II. t. 
À memória do meu pai, Jerônimo José de Araujo Souza 


\section{AGRADECIMENTOS}

Agradeço ao meu orientador, Prof. Dr. Claudio Tavares de Alencar, e aos professores do Núcleo de Real Estate da Escola Politécnica da Universidade de São Paulo, Profa. Dra. Eliane Monetti, Prof. Dr. João da Rocha Lima e Prof. Dr. Sérgio Alfredo Rosa da Silva.

Aos amigos da Escola Politécnica, Rogério Santovito, Elisabete Freitas, Fernanda Ferreira, Renato Mauro, Heliana Artigiane e Edson Kanagusuko.

À minha namorada, Adriana Rodrigo, pela atenção e companheirismo.

Aos meus pais, Neusa e Jerônimo, e às minhas irmãs Fabiana e Luciana. 


\section{RESUMO}

O objetivo da presente dissertação é verificar em que medida o nível de diversificação das empresas de Real Estate e os modelos de negócios empregados em suas estratégias de crescimento no período 2005 a 2010 possam ter influenciado o desempenho econômico das organizações. Para tanto, identificou-se o nível de diversificação geográfica e de produtos das empresas nos anos do período, e os principais modelos de negócios empregados para a entrada em novos mercados e segmentos de renda. Em seguida, as empresas foram estratificadas em grupos, segundo o nível de diversificação e os modelos de negócios predominantes. Para cada grupo, determinou-se a capacidade de geração de renda e valor econômico para o acionista. Os grupos foram comparados entre si e com o desempenho médio das empresas do setor. A pesquisa faz uso das empresas de Real Estate listadas no segmento Novo Mercado da BM\&FBovespa. Os resultados sugerem que para a entrada no segmento econômico e popular, os modelos de aquisição e desenvolvimento próprio se mostraram mais eficientes, respectivamente, do que os modelos de parcerias. A concentração de produtos se mostrou igualmente de desempenho superior. Quanto à diversificação geográfica, não foi possível estratificar as empresas para análise adequada. No entanto, a maioria das empresas de atuação nacional e municipal apresentaram resultados acima do conjunto do mercado, enquanto as empresas com atuação estadual apresentaram resultados próximos ou abaixo da média.

Palavras-chave: Real Estate. Estratégia. Modelos de negócios. Diversificação 


\begin{abstract}
This research explores the diversification, growth strategies and economic performance of the real estate companies listed on the brazilian stock exchange BM\&FBovespa. Between 2006 and 2008 years, more than twenty companies have made its inttial public offering (IPO) of its stocks. As result, and with almost $\mathrm{R} \$ 11$ billion on cash, most companies have acquired large landbanks spread over the main cities of the country, and started to built on new markets, moving away from a specialized portfolio of products to a national level and diversified portfolio companies. In order to understand the relationship between the strategies and economic performance, the research identifies the level of geographical diversification and products of each company, and the main business models used to enter into new markets - partnerships with local developers, mergers and acquisitions, or own development. The companies were stratified into groups according to the level of diversification and their business models, and for each one the profit and the return of equity patterns were analysed. The results suggested that product specialized companies seems to have superior performance than national and diversified companies, and for entry into the low income housing sector, acquisition and own development business models were better than partnerships.
\end{abstract}

keywords: Real Estate. Strategy. Business Model. Diversification 


\section{ÍNDICE DE FIGURAS}

Figura 1 - Decisões objeto de análise da dissertação

Figura 2 - Etapas da dissertação.

Figura 3 - Possibilidades de classificação segundo a diversificação do porttólio, estratégia de crescimento e modelo de negócio

Figura 4 - Matriz de Diversificação do Portfólio de Negócios de empresas de Real Estate

Figura 5 - Definições por tipos de alianças estratégicas.

Figura 6- Modelo de negócio de parcerias usualmente empregado para as estratégias de expansão geográfica.

Figura 7 - Critérios e segmentos de mercados utilizados para classificação dos produtos/empreendimentos.

Figura 8 - Classificação das empresas segundo a diversificação do portfólio, estratégias de crescimento e modelos de negócios

Figura 9 - Critérios para classificação da diversificação geográfica.

Figura 10 - Processo para classificação da diversificação de produtos.

Figura 11 - Processo para cálculo do índice de concentração por modelo de negócio

Figura 12 - Mapa de lançamentos da empresa CCDI ...........................................72

Figura 13 - Mapa de lançamentos da empresa Cyrela...........................................76

Figura 14 - Mapa de lançamentos das empresas Brascan e Company. ................80

Figura 15 - Mapa de lançamentos da Empresa Brookfield.....................................81

Figura 16 - Mapa de lançamentos da empresa Trisul ..........................................85

Figura 17 - Mapa de lançamentos da empresa Gafisa. .........................................89

Figura 18 - Mapa de lançamentos da empresa Tenda ........................................92

Figura 19 - Mapa de lançamentos da empresa CR2 …………............................96

Figura 20 - Mapa de lançamentos da empresa PDG ……..............................100

Figura 21 - Mapa de lançamentos da empresa MRV ..........................................104 
Figura 22 - Mapa de lançamentos da empresa Rodobens ..................................107

Figura 23 - Mapa de lançamentos da empresa Tecnisa .....................................110

Figura 24 - Mapa de lançamentos da empresa Abyara......................................115

Figura 25 - Mapa de lançamentos da empresa JHSF .....................................118

Figura 26 - Mapa de lançamentos da empresa Helbor .......................................122

Figura 27 - Mapa de lançamentos da empresa Eztec .........................................125

Figura 28 - Mapa de lançamentos da empresa Even ........................................128

Figura 29 - Mapa de lançamentos da empresa Rossi .........................................132

Figura 30 - Diversificação do portfólio - Ano 2005..............................................134

Figura 31 - Diversificação do portfólio - Ano 2006 ...............................................135

Figura 32 - Diversificação do portfólio - Ano 2010 ................................................135

Figura 33 - Diversificação do portfólio no período 2005-2010 ……........................136 


\section{ÍNDICE DE GRÁFICOS}

Gráfico 1 - Evolução do patrimônio líquido médio e comportamento dos indicadores de desempenho das empresas de Real Estate listadas no segmento construção civil da BM\&FBovespa

Gráfico 2 - Evolução da participação dos estados de São Paulo e Rio de Janeiro no portfólio de lançamentos

Gráfico 3 - Evolução da participação dos municípios de São Paulo e Rio de Janeiro no portfólio de lançamentos.

Gráfico 4 - Banda de variação do indicador margem líquida do conjunto da amostra de empresas.

Gráfico 5 - Número de alianças estratégicas por tipo firmadas pelas empresas do segmento construção civil da BM\&FBovespa no período de 2006 a 2010.

Gráfico 6 - Lançamentos por segmento de renda - CCDI ......................................71

Gráfico 7 - Lançamentos por segmento de renda - Cyrela .....................................76

Gráfico 8 - Lançamentos por segmento de renda - Company …….........................79

Gráfico 9 - Lançamentos por segmento de renda - Brascan ....................................79

Gráfico 10 - Lançamentos por segmento de renda -Brookfield. ...............................80

Gráfico 11 - Lançamentos por segmento de renda - Trisul. ..................................84

Gráfico 12 - Lançamentos por segmento de renda - Gafisa ....................................89

Gráfico 13 - Lançamentos por segmento de renda - Tenda ....................................92

Gráfico 14 - Lançamentos por segmento de renda - CR2 ….................................96

Gráfico 15 - Lançamentos por segmento de renda - PDG ....................................100

Gráfico 16 - Lançamentos por segmento de renda - MRV..................................103

Gráfico 17 - Lançamentos por segmento de renda - Rodobens ............................107

Gráfico 18 - Lançamentos por segmento de renda - Tecnisa................................110

Gráfico 19 -Lançamentos por segmento de renda - Agra ...................................112

Gráfico 20 - Lançamentos por segmento de renda - KlabinSegall .........................113 
Gráfico 21 - Lançamentos por segmento de renda - Abyara ................................114

Gráfico 22 - Lançamentos por segmento de renda - JHSF .................................117

Gráfico 23 - Lançamentos por segmento de renda - Helbor ...................................122

Gráfico 24 - Lançamentos por segmento de renda - Eztec ..................................125

Gráfico 25 - Lançamentos por segmento de renda - Even ....................................128

Gráfico 26 - Lançamentos por segmento de renda - Rossi ..................................131

Gráfico 27 - Evolução da margem líquida do grupo de empresas da tabela 21 ......141

Gráfico 28 - Evolução do lucro sobre o patrimônio líquido do grupo de empresas da

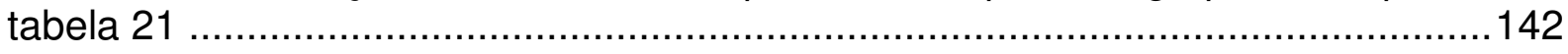

Gráfico 29 - Evolução da margem líquida do grupo de empresas da tabela 22 _.....143

Gráfico 30 - Evolução do lucro sobre o patrimônio líquido do grupo de empresas da tabela 22 ......

Gráfico 31 - Evolução da margem líquida do grupo de empresas da tabela acima 145

Gráfico 32 - Evolução do lucro sobre o patrimônio líquido do grupo de empresas da tabela acima

Gráfico 33 - Evolução da margem líquida em relação ao conjunto do mercado para diferentes estratégias de crescimento e modelos de negócios

Gráfico 34 - Evolução do lucro sobre o patrimônio líquodo em relação ao conjunto do mercado para diferentes estratégias de crescimento e modelos de negócios

Gráfico 35 - Margem Líquida e Lucro sobre o Patrimônio Líquido por empresa em relação ao conjunto do mercado - acumulado para o período 2006-2010 151

Gráfico 36 - Evolução em pontos percentuais sobre o conjunto do mercado dos indicadores de desempenho entre 2006-2010 151 


\section{ÍNDICE DE TABELAS}

Tabela 1 - Tipos de alianças estratégicas horizontais na incorporação imobiliária da

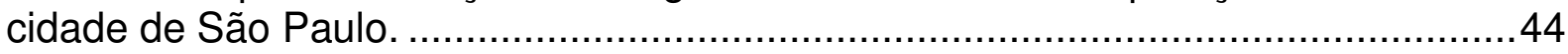

Tabela 2 -Indicadores de diversificação para as empresas protótipo..........................66

Tabela 3 - Painel de Indicadores da empresa CCDI. ..........................................73

Tabela 4 - Painel de Indicadores da empresa Cyrela............................................77

Tabela 5 - Painel de Indicadores da empresa Company......................................82

Tabela 6 - Painel de Indicadores das empresas Brascan e Brookfield. ....................83

Tabela 7 - Painel de Indicadores da empresa Trisul. ..........................................86

Tabela 8 - Painel de Indicadores da empresa Gafisa..........................................90

Tabela 9 - Painel de Indicadores da empresa Tenda.............................................93

Tabela 10 - Painel de Indicadores da empresa CR2 …….................................97

Tabela 11 - Painel de Indicadores da empresa PDG. ..........................................101

Tabela 12 - Painel de indicadores da empresa MRV. ……....................................105

Tabela 13 - - Painel de indicadores da empresa Rodobens................................108

Tabela 14 - Painel de indicadores da empresa Tecnisa.....................................111

Tabela 15 - Painel de indicadores da empresa JHSF ......................................119

Tabela 16 - Painel de indicadores da empresa Helbor.......................................123

Tabela 17 - Painel de indicadores da empresa Eztec. ........................................126

Tabela 18 - Painel de indicadores da Empresa Even.........................................129

Tabela 19- Diversificação e modelos de negócios realizados pelas empresas no

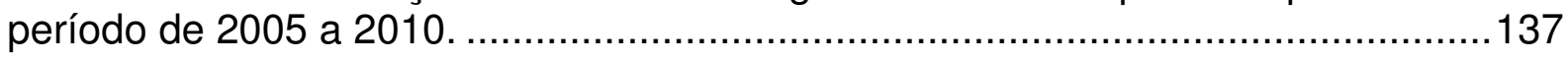

Tabela 20 - Empresas para análise da influência da diversificação geográfica ......141

Tabela 21 - Empresas para análise da influência da diversificação geográfica. .....143

Tabela 22 - Empresas para análise da influência da diversificação de produto......144

Tabela 23 - Indicador Margem Líquida por empresa.........................................146 
Tabela 24 - Indicador Lucro sobre o Patrimônio Líquido por empresa.....................147

Tabela 25 - Resultado por categoria de estrategia..........................................154 


\section{SUMÁRIO}

1. INTRODUÇÃO

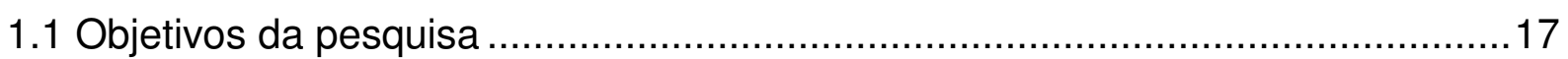

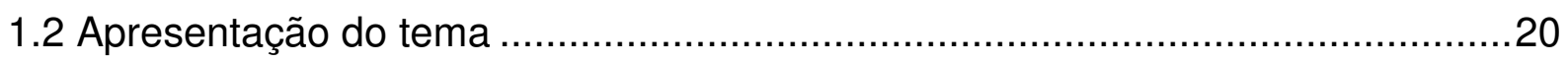

2. METODOLOGIA

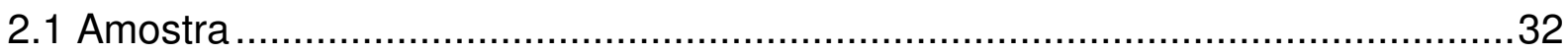

2.2 Base de dados

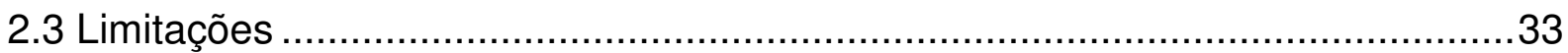

3. DIVERSIFICAÇÃO DO PORTFÓLIO DE EMPREENDIMENTOS E MERCADOS

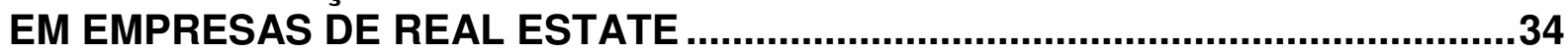

3.1 Concentração e diversificação em empresas de Real Estate ............................34

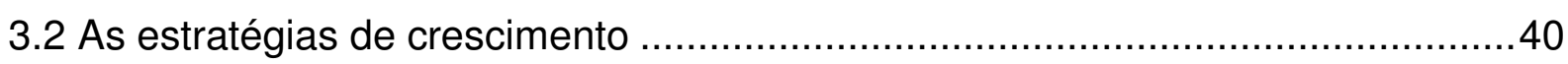

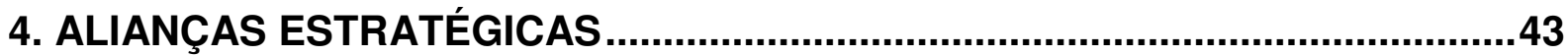

4.1 Alianças estratégicas como meio de crescimento e diversificação ....................50

4.2 Alianças estratégicas como meio de absorção de conhecimento e vantagens

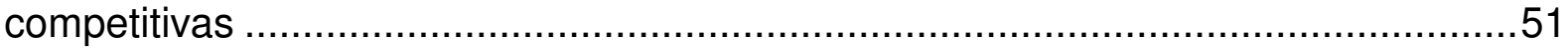

5. ÍNDICES PARA MEDIDAS DE CONCENTRAÇÃO E DIVERSIFICAÇÃO...........53

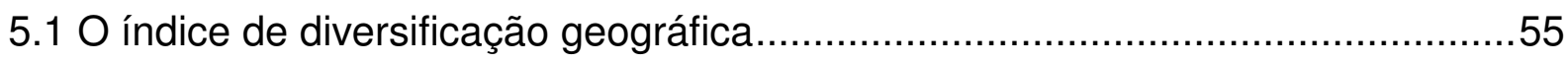

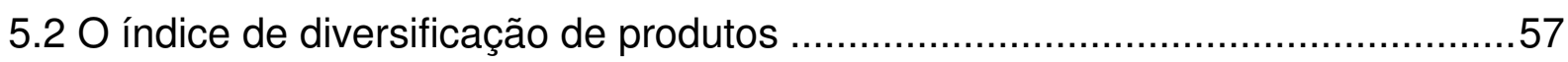

6. CRITÉRIOS PARA CLASSIFICAÇÃO DAS EMPRESAS SEGUNDO A DIVERSIFICAÇÃO DO PORTFÓLIO DE EMPREENDIMENTOS, ESTRATÉGIAS DE CRESCIMESTO E MODELOS DE NEGÓCIOS …........................................60

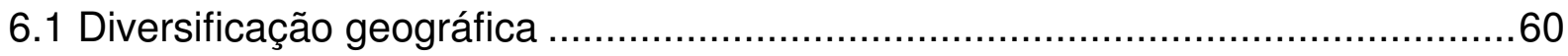

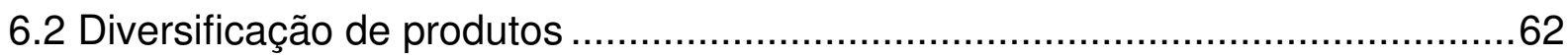

6.3 Estratégias de crescimento e modelos de negócios ......................................63

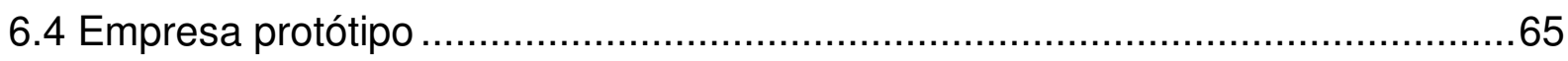

6.5. Critérios e indicadores para a avaliação do desempenho do conjunto do mercado e das empresas de Real Estate .............................................................67

7. RESULTADOS

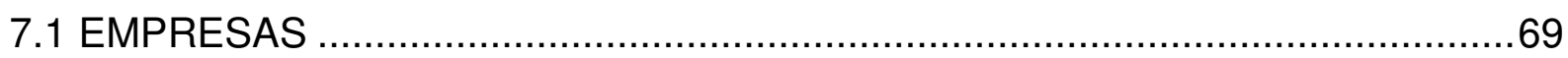

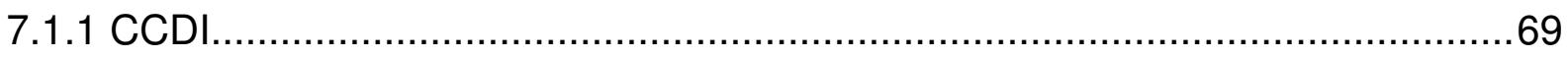

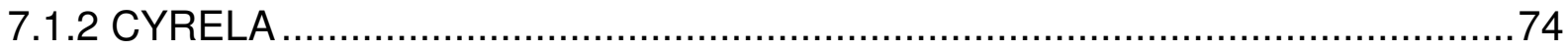




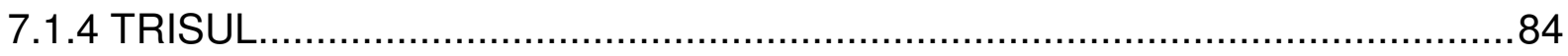

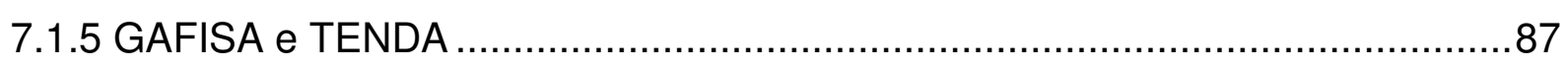

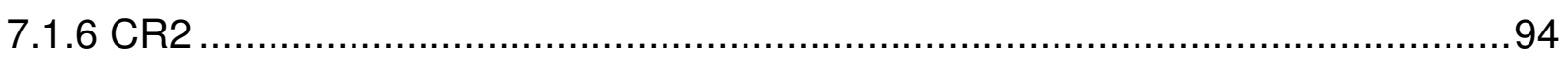

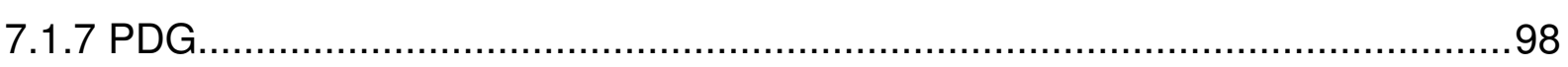

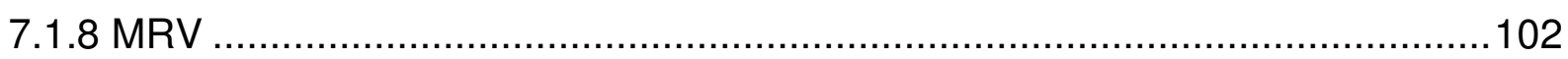

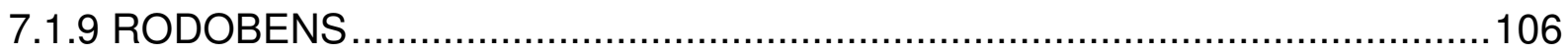

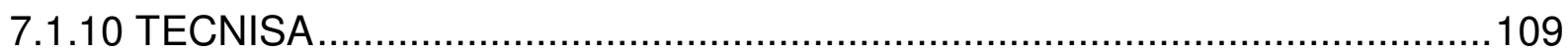

7.1.11 AGRA, KLABIN SEGALL, ABYARA E AGRE...................................112

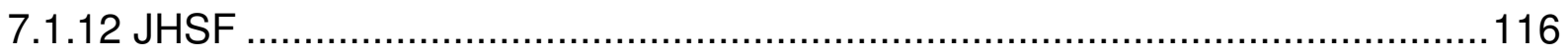

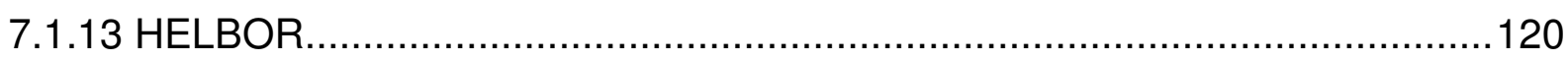

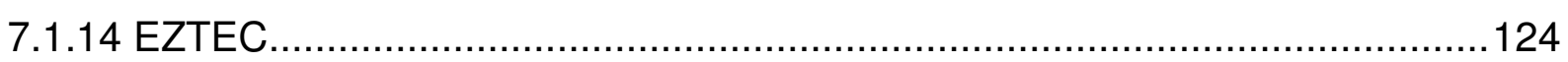

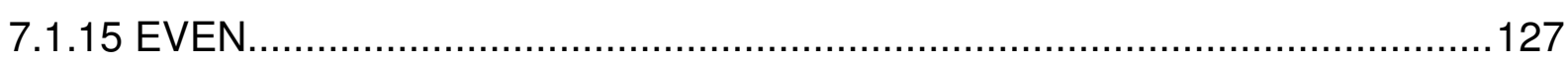

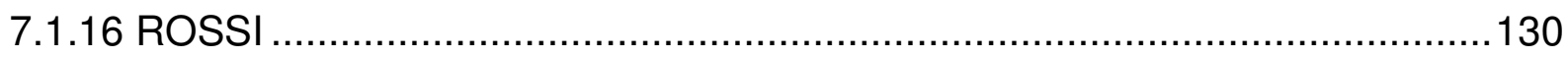

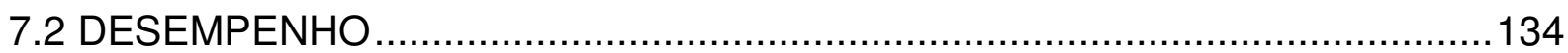

7.2.1 Análise da influência do nível de diversificação do portfólio nos indicadores de

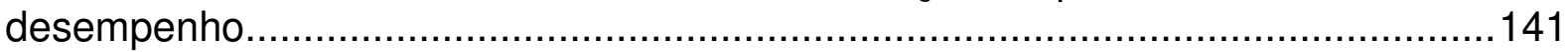

7.2.2 Análise da influência dos modelos de negócios nos indicadores de

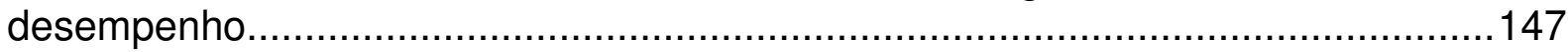

7.2.3 Análise do comportamento dos indicadores de desempenho ......................150

8. DISCUSSÕES E INTERPRETAÇÃO DOS RESULTADOS …...........................152

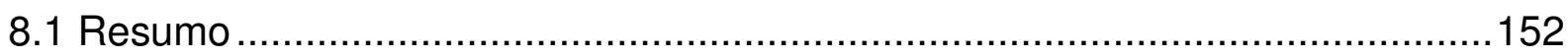

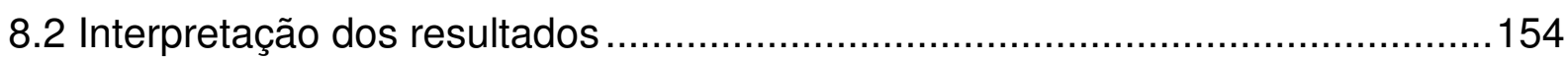

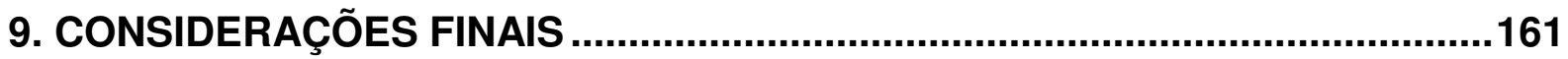

10.REFERÊNCIAS

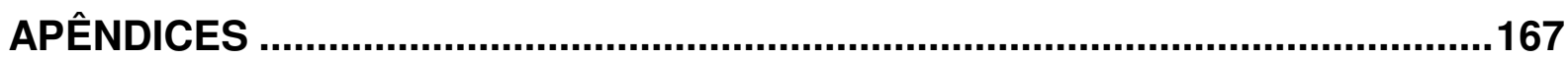

Apêndice A - Lançamentos por Município no período 2006 a 2010 .......................168

Apêndice B - Lançamentos por Mesoregião no período 2006 a 2010 .....................172

Apêndice C - Lançamentos por estados no período 2006 a 2010 .........................173

Apêndice D - Segmentação de produtos por empresas ......................................174

Apêndice F - Alianças Estratégicas identificadas no período 2006-2010 …...........176

Apêndice G - Lançamentos por empresa ....................................................... 182

Apêndice H - Índice de Concentração por Modelo de Negócio .............................. 183

Apêndice I - Dados financeiros ..................................................................... 185 


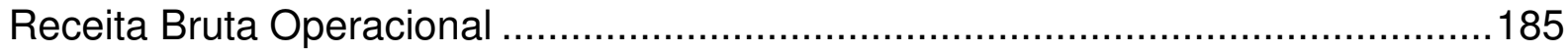

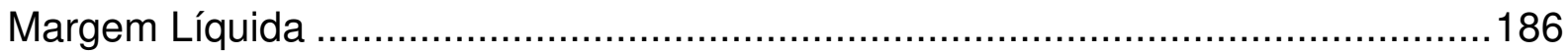

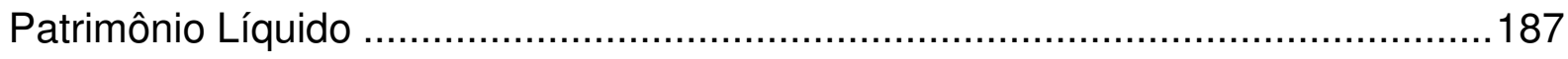




\section{INTRODUÇÃO}

\subsection{Objetivos da pesquisa}

O objetivo da presente dissertação é verificar em que medida o nível de diversificação das empresas de Real Estate e os modelos de negócios empregados em suas estratégias de crescimento no período 2005 a 2010 possam ter influenciado no desempenho destas organizações.

A pesquisa tem como foco de investigação as empresas de Real Estate de produtos residenciais e não residenciais ${ }^{1}$ para venda, listadas no novo mercado do segmento construção civil da BM\&FBovespa.

Considerando o crescimento do volume de empreendimentos e receitas que as empresas realizaram no período, a pesquisa busca investigar as influências de três escolhas em nível estratégico das organizações.

A primeira delas diz respeito à definição do portfólio de produtos e mercados. Dentro do ambiente setorial do Real Estate, a empresa deve posicionar-se e definir o que produzir e para quem produzir. A escolha implica em definir o nível de diversificação almejado pela empresa e as competências que ela terá de perseguir .

A segunda questão refere-se à decisão de crescimento. Para onde a empresa deve orientar o seu crescimento: se para produtos e mercados já conhecidos ou para novos negócios.

A terceira questão refere-se aos modelos de negócios a serem empregados para perseguir os novos produtos ou mercados. Se por desenvolvimento próprio, a partir da capacitação de recursos e meios internos à companhia, ou a partir de parcerias e aquisições e alianças estratégicas com empresas que já possuam acesso ao produto ou mercado almejado pela organização.

\footnotetext{
${ }^{1}$ Não residenciais: escritórios, salas ou conjuntos comerciais para venda. Empresas que desenvolvem empreendimentos para renda não fazem parte do escopo do presente trabalho.
} 
A Figura 01 apresenta a hierarquia das decisões estratégicas objeto de investigação.

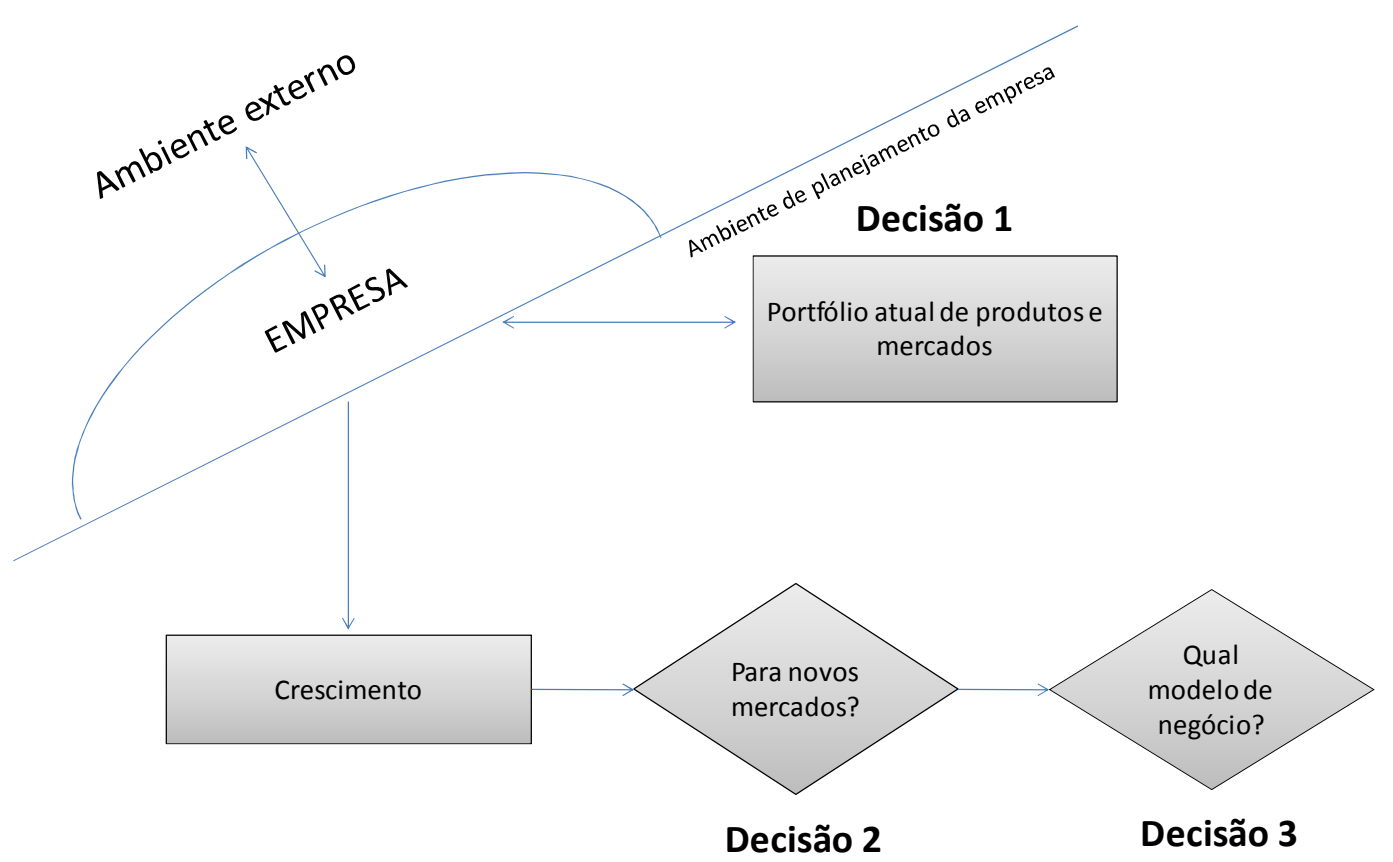

Figura 1 - Decisões objeto de análise da dissertação

Com o objetivo de prover elementos para colaborar com as decisões das questões supracitadas, limitado ao ambiente das empresas de Real Estate, a pesquisa faz uso do comportamento de vinte e uma ${ }^{2}$ empresas listadas no setor Construção Civil do segmento Novo Mercado da BM\&FBovespa. Para tanto, identifica-se o nível de diversificação por produtos e mercados de cada empresa, suas escolhas de crescimento e modelos de negócios empregados durante o período 2005 a 2010. Em seguida, as empresas são estratificadas em grupos, com o objetivo de tentar isolar e analisar as influências de cada decisão no desempenho econômico auferido no período.

Para classificação das empresas quanto sua diversificação, levou-se em conta o

\footnotetext{
${ }^{2}$ Tenda,Abyara,Rodobens,Cyrela,Gafisa,Rossi,PDG,JHSF,Brookfield,MRV,CR2,Agra,Tecnisa,Helbor, KlabinSegall,CCDI,Trisul,Even,Brascan,Company,Eztec. A empresa Direcional Engenharia não consta na análise devido ao curto período de capital aberto, bem como a empresa Inpar(Viver) devido à ausência de informações operacionais em nível de detalhamento suficiente para atendimento dos objetivos da pesquisa.
} 
número de produtos e mercados do portfólio de novos empreendimentos da companhia, e sua representatividade no volume estimado de venda ${ }^{3}$ dos lançamentos. A combinação do nível de diversificação em cada território resultou nas seguintes classificações: empresas de atuação (i) Municipal, (ii) Regional, (iii) Estadual ou (iv) Nacional. Quanto à diversificação de produtos, levou-se em consideração igualmente o número de segmentos de renda e a representatividade de cada um, em volume estimado de venda, resultando em empresas de portfólio (i) concentrado, (ii) dominante e (iii) diversificado. Os índices utilizados, suas limitações, fórmulas e detalhamentos são apresentados no capítulo seis.

Para cada lançamento identificado, a pesquisa o classificou quanto ao seu objetivo dentro da estratégia de crescimento da organização (se para novos produtos ou mercados), e por meio de qual modelo de negócio o empreendimento foi executado desenvolvimento próprio, parcerias, joint ventures ou aquisições. Para tanto, aplicouse critérios que buscaram estimar, por meio das melhores informações disponíveis, os modelos de negócios mais prováveis, cujos detalhes são apresentados no capítulo sete.

Por fim, para verificação das relações entre as escolhas de portfólio de empreendimentos, estratégias de crescimento e modelos de negócios, para com a eficiência da empresa em gerar renda e valor para o acionista, foram empregados os indicadores margem líquida e resultado sobre o patrimônio líquido.

Os indicadores foram calculados para o conjunto das empresas [conjunto do mercado], para cada empresa e para cada grupo, ano a ano e acumulado para o período $2006^{4}$ a 2010.

Em razão do curto período (2005 a 2010), e do número restrito de empresas, a pesquisa não tem como objetivo determinar, e nem seria possível, relações causais ou correlações com significância estatística entre desempenho e estratégia. No entanto, a dissertação explora os dados de estratégias e desempenho a fim de auxiliar o autor no entendimento do impacto que o nível de diversificação e os modelos de negócios

\footnotetext{
${ }^{3}$ Usualmente denominado pelo mercado como valor geral de vendas (VGV)

4 A pesquisa analisa a diversificação do portfólio a partir do ano 2005 , no entanto, para análise das relações com o desempenho econômico das organizações o período é de 2006 a 2010.
} 
tiveram no desempenho das organizações.

\subsection{Apresentação do tema}

Um dos principais objetivos dos estudos de estratégia é buscar o entendimento dos motivos das diferenças de desempenho entre organizações. Diferentes decisões estratégicas resultam em diferentes posicionamentos e competências para as empresas e, eventualmente, em distintos padrões de desempenho.

A cadeia da construção civil, mais especificamente o segmento voltado à construção residencial e comercial, carece de literatura sobre o tema proporcionalmente à sua importância econômica, seja em geração de empregos, geração de riqueza e função social que exerce.

Se considerarmos o período compreendido a partir de 2005, o crescimento econômico do Brasil, a redução da taxa básica de juros e a maior disponibilidade de crédito para o financiamento da aquisição habitacional e construção de moradias, fez as empresas do setor almejarem, e de fato efetivarem, um significativo crescimento em volume de obras. Crescimento este que exigiu um novo porte de empresas de Real Estate, que demandou novos processos de decisão, gestão e níveis de transparência das organizações.

Com o objetivo de financiar o crescimento almejado, e incentivadas pelos bancos e corretoras, entre 2006 e 2007 vinte e duas empresas de Real Estate abriram capital no segmento construção civil da BM\&FBovespa, captando aproximadamente R\$ 11 bilhões (moeda corrente) segundo dados levantados pelo próprio autor. Parte expressiva deste montante foi utilizada para aquisição de extensos bancos de terrenos, em sua maioria localizados em regiões fora dos limites tradicionais de atuação pelas empresas.

Acostumadas a operar em volumes de capital aproximadamente 10 vezes inferior, as empresas se viram obrigadas a remunerar o capital dos novos acionistas a partir do dia seguinte à abertura de capital, em níveis de transparência e governança antes não 
exigidos. O Gráfico 1 ilustra a evolução do patrimônio líquido ${ }^{5}$ das empresas, e o comportamento dos indicadores margem líquida e resultado sobre o patrimônio líquido.

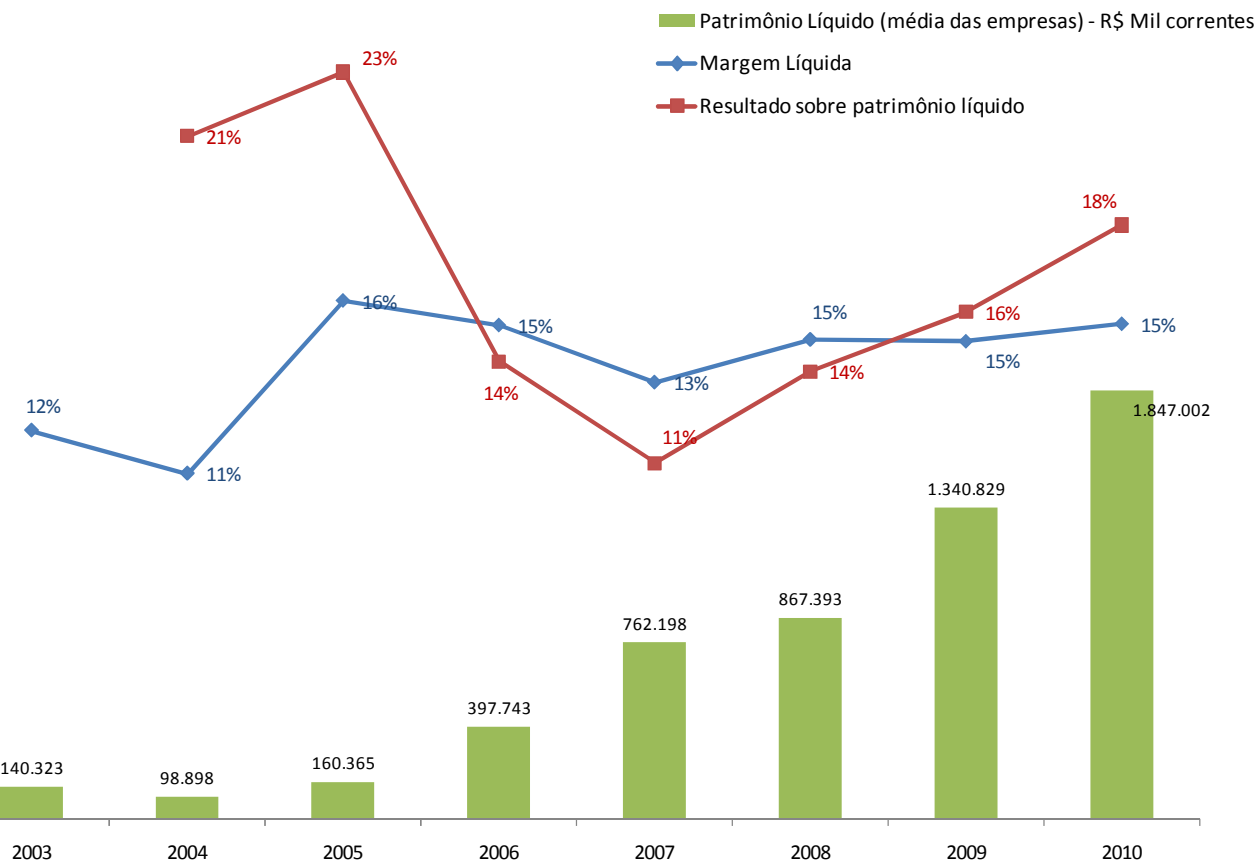

Gráfico 1 - Evolução do patrimônio líquido médio e comportamento dos indicadores de desempenho das empresas de Real Estate listadas no segmento construção civil da BM\&FBovespa.

Fonte: Elaboração do autor

Verifica-se no Gráfico acima que os indicadores oscilaram negativamente nos anos de abertura de capital, e entraram em tendência de crescimento nos anos seguintes. A queda pontual da rentabilidade pode ser interpretada pelo significativo aporte de novos recursos, de montante incompatível com o fluxo de renda proporcionado pelo portfólio de empreendimentos em regime, que passaram a ser remunerados posteriormente, entre dois a três anos, conforme os ciclos normais dos negócios de Real Estate.

O novo volume de recursos, e os empreendimentos necessários para remunerá-los ao mesmo padrão de rentabilidade auferidos antes do $I P O^{6}$, exigiu das empresas escolhas,

\footnotetext{
${ }^{5} \mathrm{O}$ valor expresso no Gráfico é a média simples do patrimônio líquido das empresas hoje listadas no segmento da construção civil da BM\&FBovespa, exceto Inpar(Viver), Direcional engenharia e as empresas que não existiam nos anos anteriores ao IPO.

${ }^{6}$ Sigla para initial public offering, comumente utilizada para se referir à abertura de capital, ou primeira oferta primária de ações em bolsa de valores.
} 
primeiramente $^{7}$ em nível estratégico, dos produtos e mercados que seriam objeto de investimentos, e, na hipótese destes serem novos para as companhias, por meio de quais modelos de negócios as empresas buscariam acessá-los.

Neste contexto, e aliado a um cenário de crescimento econômico, maior disponibilidade de crédito e marcos regulatórios importantes, as empresas deram início a um movimento de expansão para novas geografias e segmentos de renda.

Se analisado o portfólio de lançamento das empresas em 2005, verifica-se que os estados de São Paulo e Rio de Janeiro representavam aproximadamente $100 \%$ do portfólio de novos lançamentos em volume estimado de vendas. Em 2010, a participação de ambos caiu para 58\%. Os estados de Minas Gerais, Bahia, Rio Grande do Sul, Paraná, Goiás e o Distrito Federal foram os principais novos destinos.

A evolução da concentração dos lançamentos dos estados e capitais de São Paulo e Rio de Janeiro é representada pelos Gráficos 02 e 03, respectivamente.

\footnotetext{
${ }^{7}$ Convém citar que a ordem racional da formulação da estratégia empresarial é anterior à decisão da estratégia de financiamento, no entanto, no caso específico do aquecimento vivido pelo setor brasileiro, eventuais inversões de ordem podem ter ocorrido.
} 


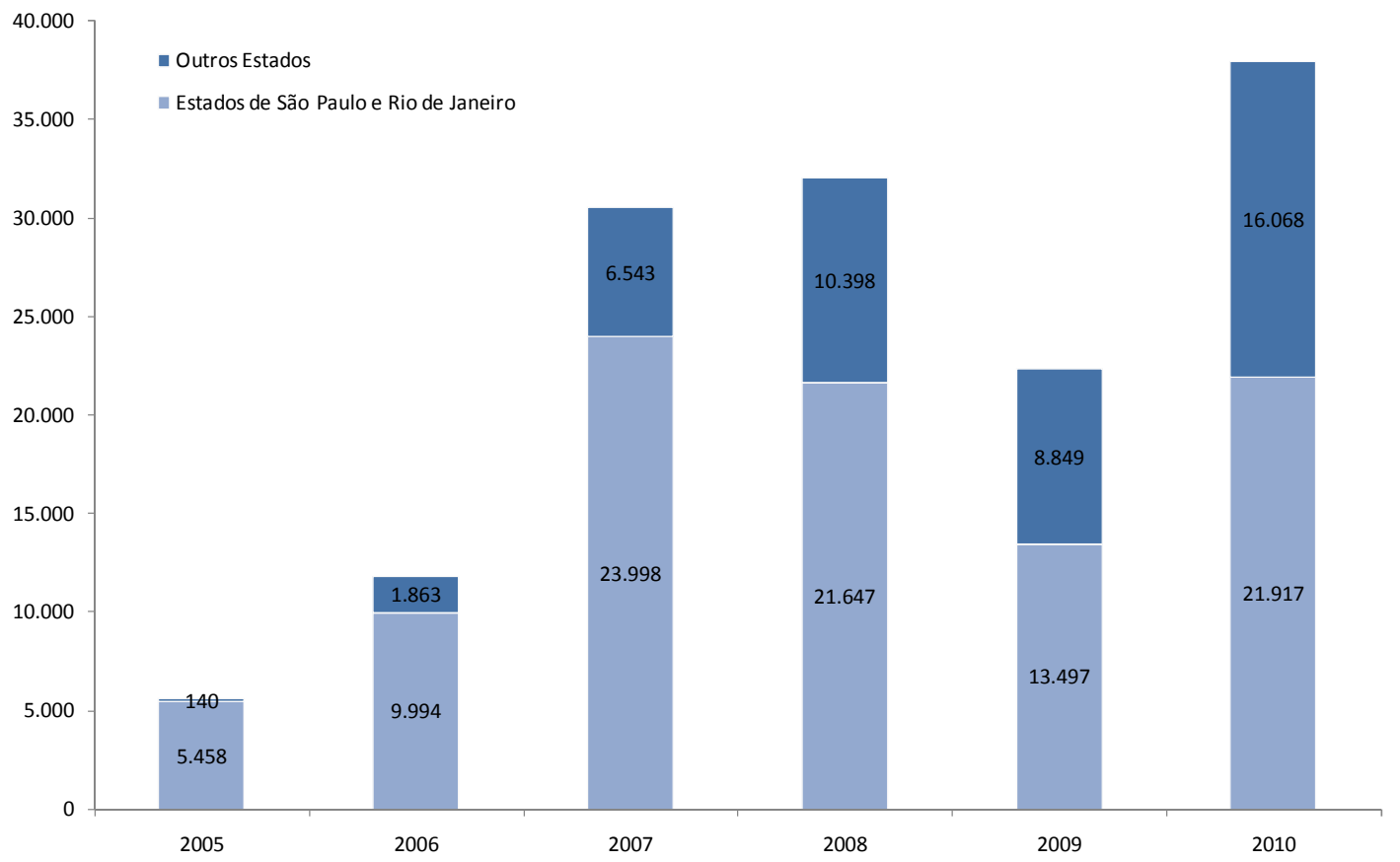

Gráfico 2 - Evolução da participação dos estados de São Paulo e Rio de Janeiro no portfólio de lançamentos. Em volume estimado de venda R $\$$ milhões da base.

Fonte: Elaboração do autor

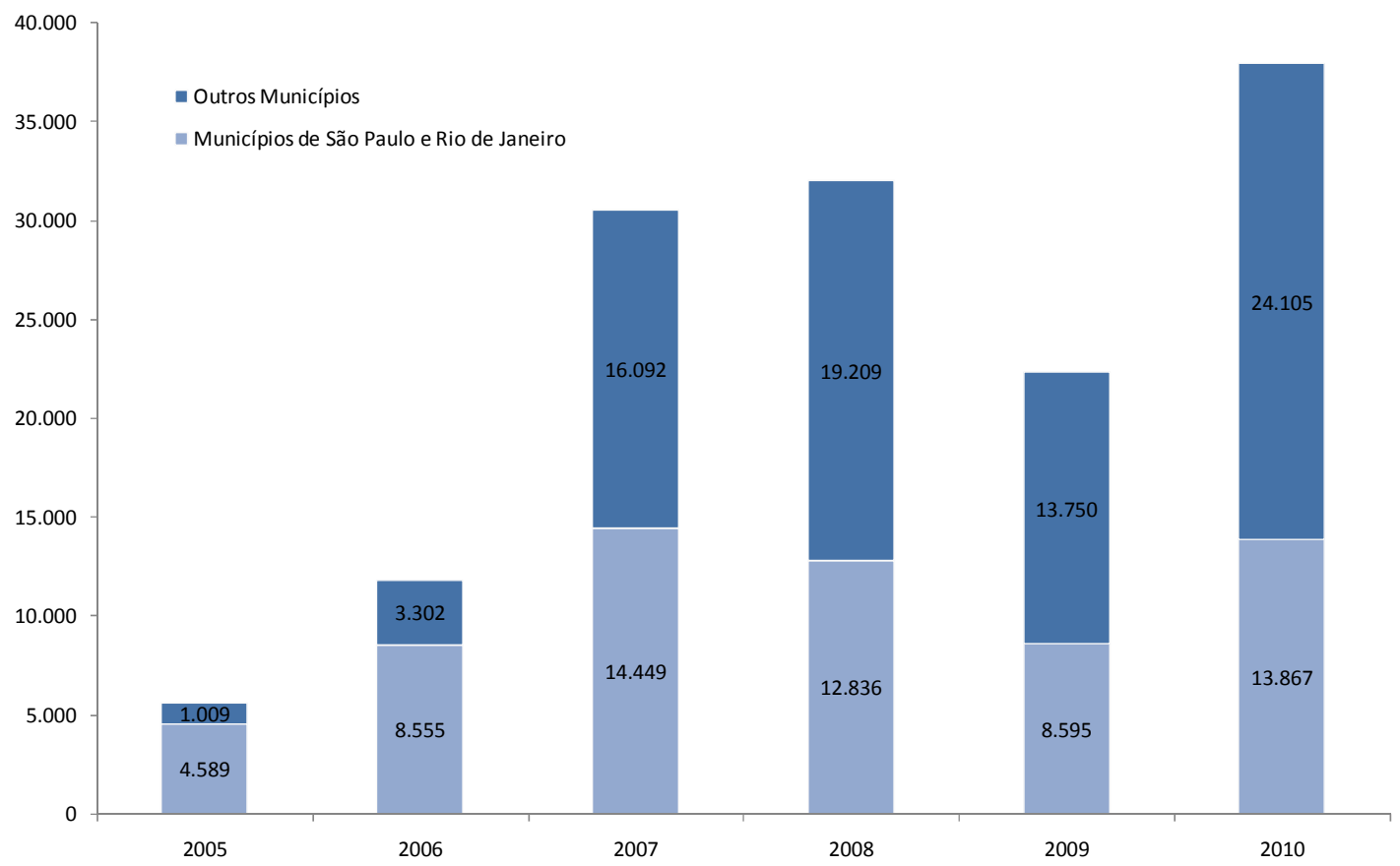

Gráfico 3 - Evolução da participação dos municípios de São Paulo e Rio de Janeiro no portfólio de lançamentos em volume estimado de venda $\mathrm{R} \$$ milhões da base.

Fonte: Elaboração do autor 
A estratégia de expansão também se refletiu nos segmentos de renda acessados pelas empresas. Conforme levantamento realizado pelo autor, no ano de 2005 aproximadamente $15 \%$ do volume estimado de venda dos novos empreendimentos tiveram como destino os segmentos econômico e popular ${ }^{8}$. No ano de 2010, a participação de ambos cresceu para $46 \%$ do portfólio de lançamentos.

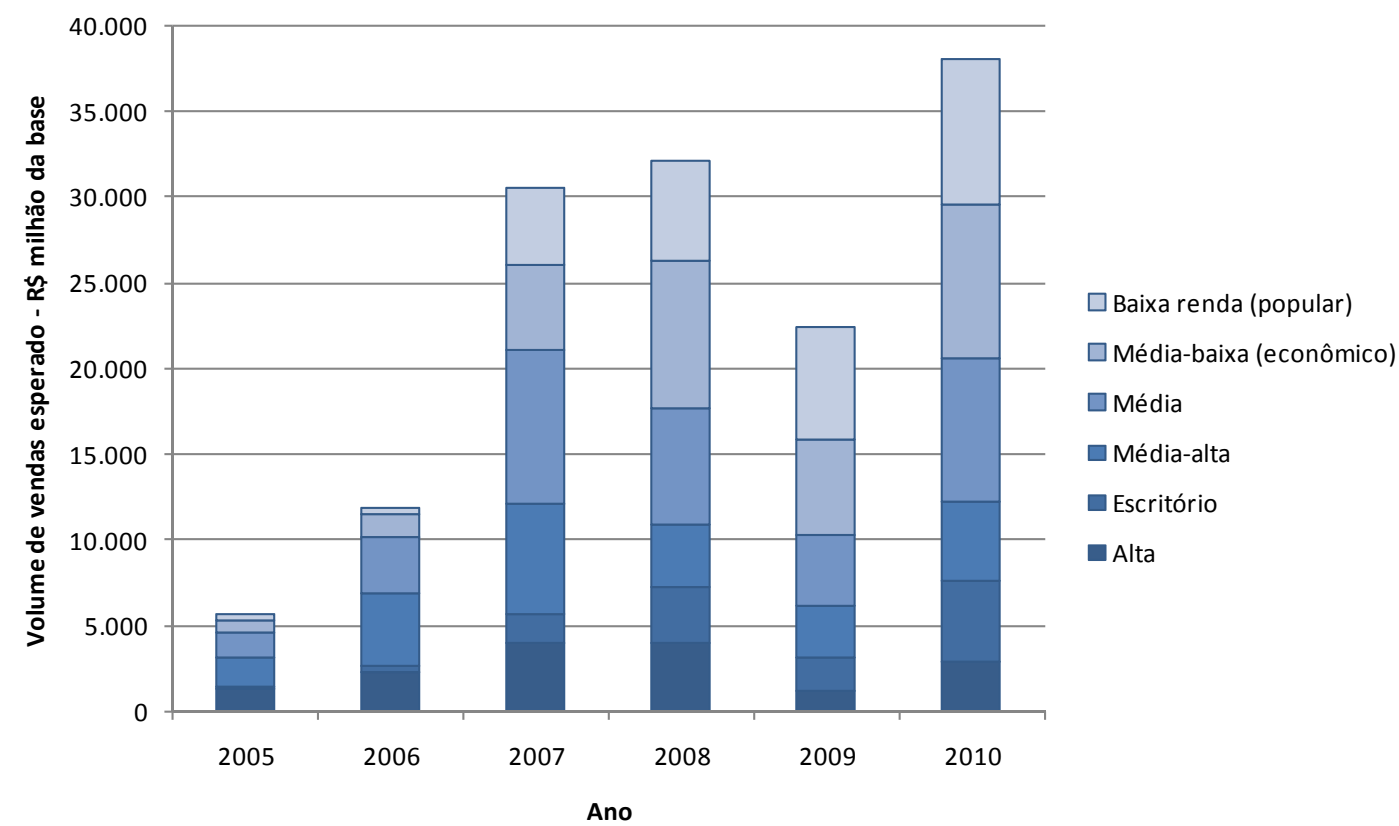

Gráfico 4 - Evolução da participação dos segmentos de renda no portfólio de lançamentos em volume estimado de venda - $\mathrm{R} \$$ milhões da base.

Fonte: elaboração do autor

Da análise do Gráfico, verifica-se que o crescimento do setor se deu nos segmentos popular, econômico e médio, em razão desde a evolução do marco regulatório ${ }^{9}$, ao crescimento econômico do país, do poder de compra da população e do avanço das linhas de créditos, que propiciaram a uma importante fração da população o acesso a habitação de mercado privado.

\footnotetext{
${ }^{8}$ Por segmento econômico entende-se unidade habitacional com preço até $\mathrm{R} \$ 250$ mil em moeda da base. Por segmento popular, preço até R\$ $130 \mathrm{mil}$ da base por unidade habitacional. Os critérios adotados para classificação dos empreendimentos por segmento de renda são apresentados noa metodologia.

${ }^{9}$ Em 2004 foi regulamentada a lei 10.931/04, instituindo o instrumento do patrimônio de afetação
} 
Neste ambiente de crescimento do volume de produção e de um mercado novo para as empresas, as companhias fizeram uso de diferentes estratégias para a entrada nos segmentos econômico e popular.

Segundo dados levantados pelo próprio autor, por meio de base constituída para os fins desta pesquisa, no período 2006-2010 foram identificados oitenta e seis casos de parcerias ${ }^{10}$ horizontais entre as empresas de capital aberto e empresas locais, doze joint ventures, dezesseis aquisições e três casos de fusões.

Das parcerias identificadas, nove tiveram como objetivo declarado a expansão para os segmentos de menor renda, nove foram constituídas com o intuito de ampliar as oportunidades nos mercados tradicionais, sessenta e sete com o objetivo de entrar em novas regiões geográficas e apenas uma dela com o objetivo declarado de acessar novas regiões e segmentos de renda simultaneamente.

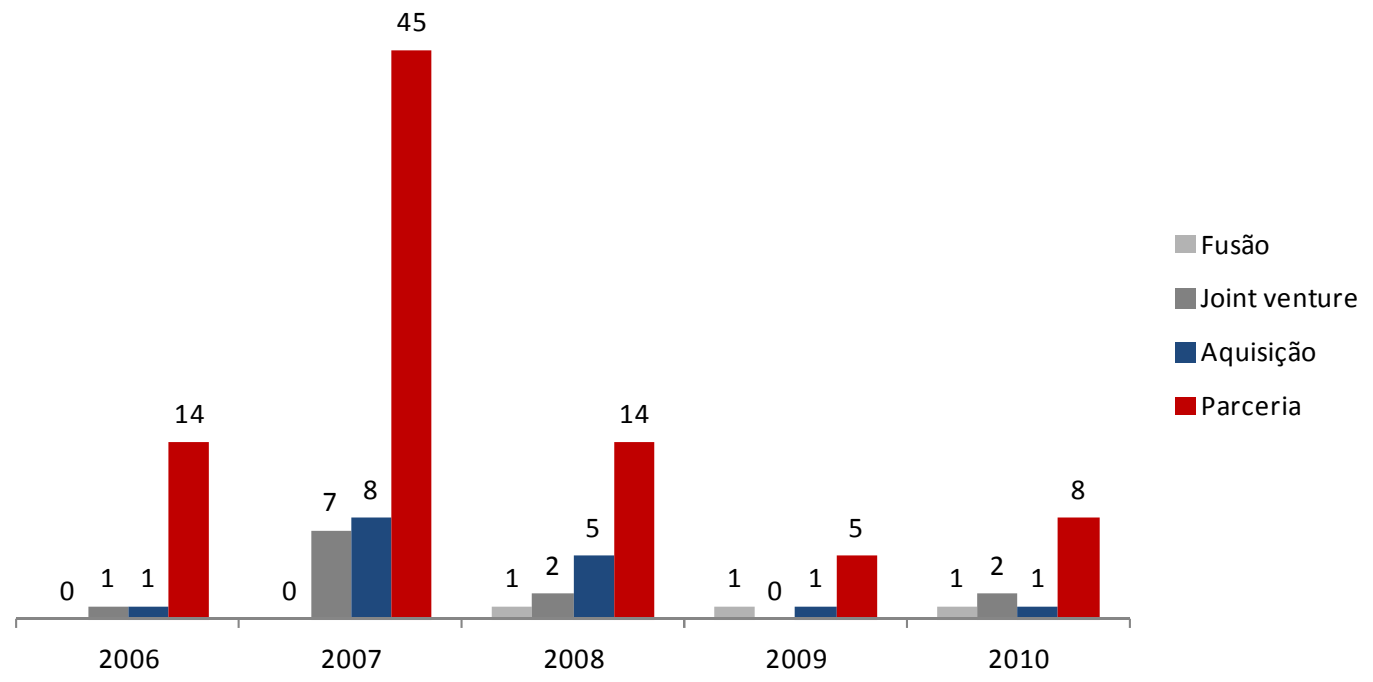

Gráfico 5 - Evolução do número de alianças estratégicas.

Fonte: elaboração do autor

Verifica-se no Gráfico acima que o pico do número de parcerias se dá no ano de 2007, justamente o ano de maior oferta primária de ações na BM\&FBovespa.

\footnotetext{
${ }^{10}$ Parcerias: acordo operacional em nível de empresa, sem aporte de recursos, ou co-incoporação por meio da participação na sociedade de proprósito específico do empreendimento. Joint ventures: criação de uma nova entidade jurídica entre duas organizações, com o objetivo de unir esforços para atendimento de uma missão comum.
} 
A estratégia de expansão geográfica por meio de parcerias foi utilizada como meio rápido de acessar novos mercados, necessários não somente para cumprir com a estratégia de expansão geográfica declarada pelas empresas, mas também como conseqüência, haja vista a incapacidade de absorção dos novos recursos pelos mercados tradicionais em curto período de tempo.

Segundo levantamentos do autor, a serem detalhados em capítulo posterior, algumas empresas não adotaram as parcerias como o modelo principal na estratégia de expansão, mas sim como meio gradual de testar novos mercados, ou ainda conhecer melhor as virtudes e fragilidades do parceiro, antes da realização de investimentos com maior intensidade, que viriam posteriormente sob o modelo de joint ventures ou aquisições.

As diferentes escolhas entre as empresas, tanto em seu nível de diversificação, por meio da escolha da combinação entre os mercados e segmentos de renda a serem acessados, bem como as decisões dos modelos de negócios utilizados para a expansão dos negócios, podem possuir riscos e problemas inerentes a cada alternativa, que por sua vez podem influenciar na eficiência da empresa em gerar renda e valor para os acionistas.

O Gráfico abaixo apresenta a banda de variação do indicador margem líquida para o conjunto de empresas do presente trabalho. Verifica-se que existem diferentes padrões de desempenho, que podem estar relacionados a fatores internos e externos às empresas. 


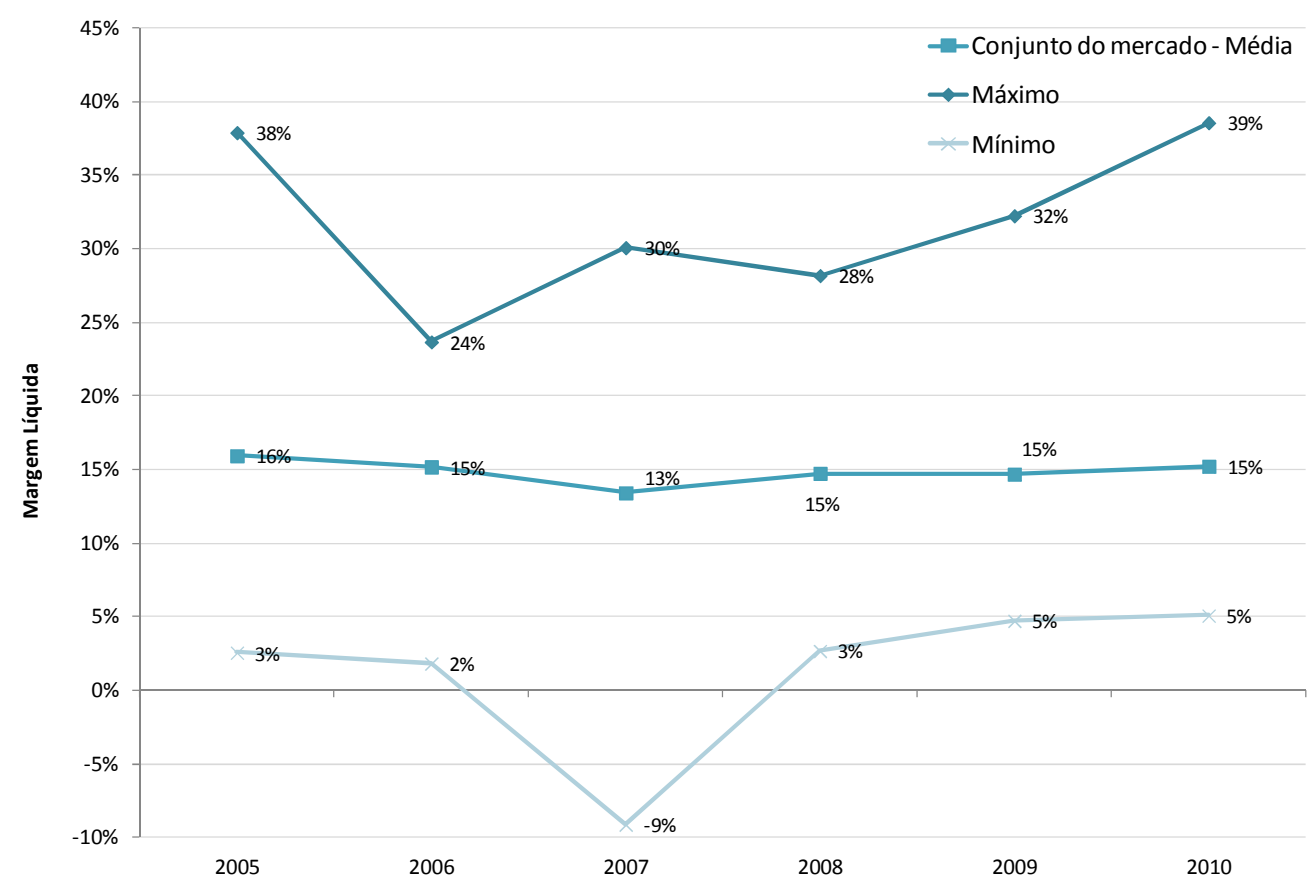

Gráfico 4 - Banda de variação do indicador margem líquida do conjunto da amostra de empresas. Fonte: Elaboração do autor

É neste contexto do setor que a pesquisa se insere, com o objetivo de identificar as estratégias de portfólio das empresas no período, os modelos de negócios utilizados na expansão para novos negócios, e verificar possíveis relações e influências no padrão de desempenho das companhias.

$\mathrm{O}$ autor entende que as decisões e estratégias das empresas devem ser registradas e classificadas formalmente, de maneira a extrair hipóteses e evidências que possam subsidiar as empresas do setor em suas futuras formulações estratégicas, e servir de base para futuros aprofundamentos.

Esta pesquisa é dedicada única e exclusivamente às empresas de Real Estate com foco na incorporação de empreendimentos residenciais e comerciais destinados para venda. Assim, é importante que os conceitos, formulações e resultados obtidos sejam interpretados dentro desta limitação setorial. 


\section{METODOLOGIA}

Para atendimento do objetivo da dissertação, a pesquisa teve de percorrer etapas no sentido de classificar as empresas, segundo critérios quantitativos, quanto aos mercados e produtos operados pelas próprias, as estratégias de crescimento adotadas no período e os modelos de negócios utilizados como meio para atendimento das estratégias de crescimento.

As Etapas percorridas pela dissertação são demonstradas esquematicamente pela Figura 02.

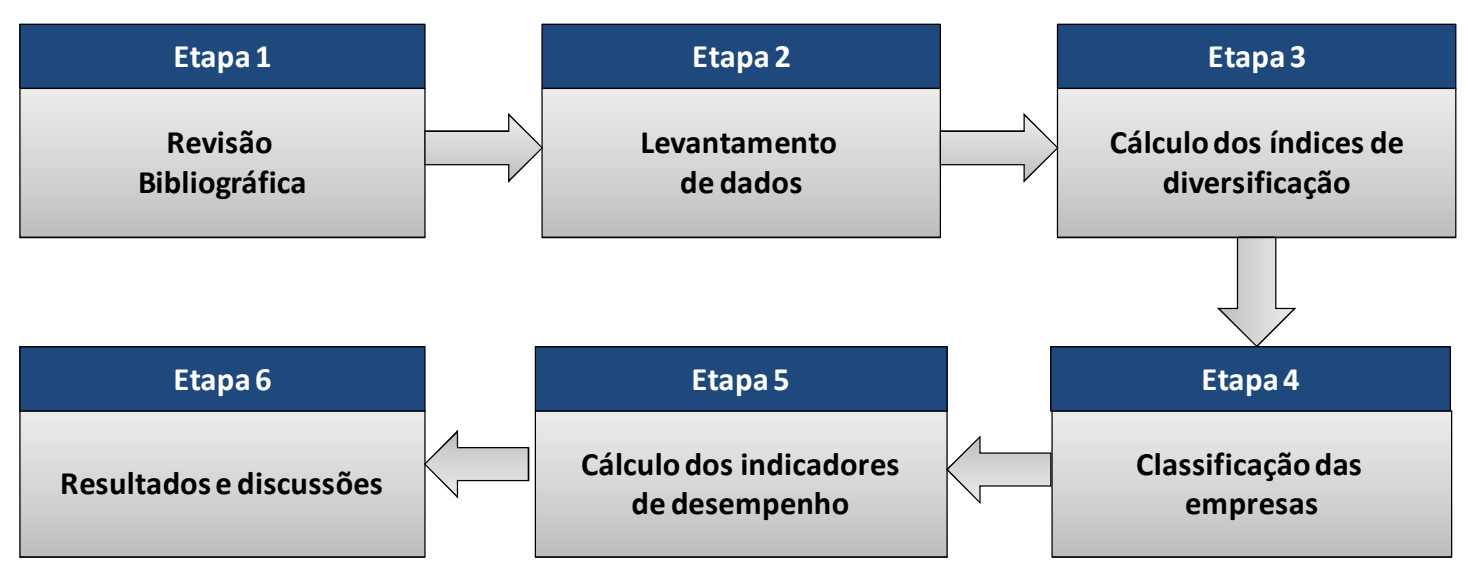

Figura 2 - Etapas da dissertação

A Etapa 1 trata da revisão bibliográfica, cujo objetivo é conhecer o corpo de conhecimento dos temas estratégia empresarial, diversificação de negócios e alianças estratégicas, e suas relações com o ambiente das empresas de Real Estate.

A Etapa 2 trata do levantamento de dados, necessários para o atendimento dos produtos e objetivos das etapas posteriores. A Etapa constitui-se da produção de base de dados, contendo a relação dos empreendimentos lançados pelas empresas entre 2005 e 2010, identificados por região geográfica, por segmento de renda e, para os lançamentos realizados em novos mercados, os modelos de negócios sob os quais foram realizados.

As informações dos empreendimentos foram obtidas por meio de pesquisa em 
documentos das empresas, tais como releases operacionais, relatórios anuais e demais documentos disponíveis nos sítios de relação com investidores das empresas. Quando necessário, houve contato formal por meio de correio eletrônico para obtenção de dados complementares.

A Etapa 3 trata do cálculo dos índices de diversificação de mercados e produtos das organizações, das estratégias de crescimento e modelos de negócios praticados no período, cujos métodos de cálculo são detalhados no capítulo 7.

A diversificação geográfica de cada empresa foi avaliada segundo três definições de territórios: municipal, mesoregional e estadual. A informação do município foi obtida por meio de fonte primária utilizada para identificação dos empreendimentos lançados no período. As demais regiões foram obtidas por meio de base oficial do IBGE Instituto Brasileiro de Geografia e Estatística.

Com o objetivo de traduzir os índices em categorias de diversificação, as empresas foram classificadas, com base na combinação dos índices por território, nas seguintes categorias: (1) concentração Municipal, (2) concentração Regional, (3) concentração Estadual e (4) Nacional. Os critérios utilizados são explicados no capítulo sete.

Para a determinação da diversificação por produtos, cada empreendimento identificado foi classificado quanto ao segmento de renda a que foi destinado, tendo como referência o preço médio de suas unidades habitacionais, caso residencial. Os empreendimentos de escritórios foram atribuídos como "comercial", independente do preço das unidades de salas ou conjuntos.

O nível de diversificação de cada empresa por produto foi traduzido nas categorias de (1) portfólio concentrado, (2) dominante e, (3) diversificado. Os métodos e critérios adotados são explicados no capítulo sete.

Para análise da estratégia de crescimento realizada pelas empresas, se penetração de mercado, expansão de mercado, produtos, ou diversificação, determinou-se a participação de cada estratégia no portfólio dos empreendimentos desenvolvidos a partir de 2006, em volume estimado de vendas. Para tanto, cada empreendimento foi 
classificado quanto ao seu objetivo no atendimento da estratégia de crescimento.

Para a determinação da participação de cada modelo de negócio nas estratégias de expansão ou diversificação dos negócios, determinou-se a participação relativa de cada modelo no portfólio dos lançamentos realizados apenas nos novos mercados ou produtos, em volume estimado de venda e para o período 2006-2010. Para a identificação do modelo, o autor fez uso das melhores informações disponíveis por empreendimento, cujo processo e detalhamento é descrito no capítulo sete. Por fim, cada empresa foi classificada conforme o modelo de negócio de maior participação no portfólio dos lançamentos realizados para os novos mercados e/ou produtos. Convém ressaltar que para o modelo de parcerias, foram consideradas apenas as mais relevantes, cuja parceria foi divulgada pela empresa como estratégica para o atendimento da expansão geográfica e/ou de produtos.
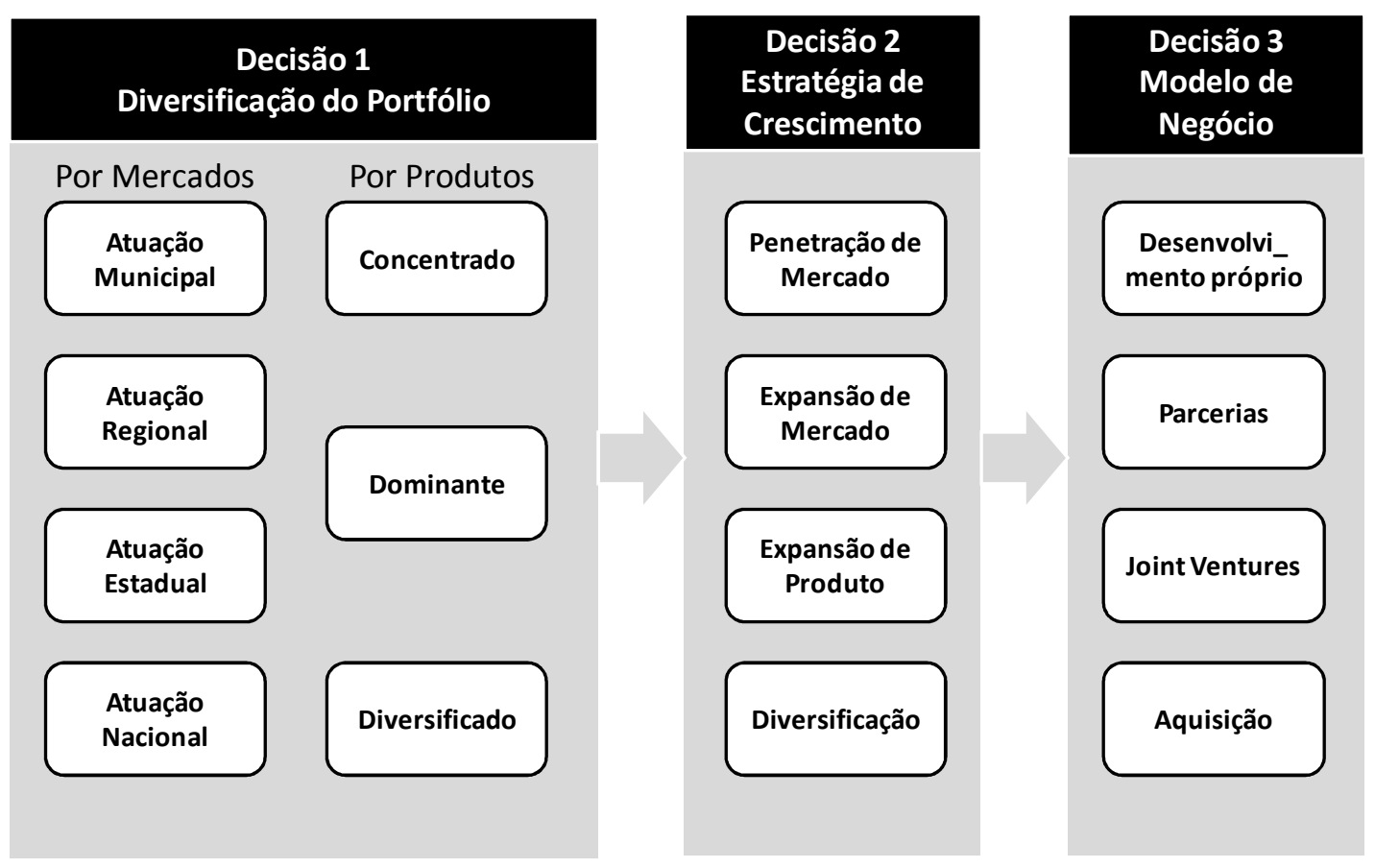

Figura 3 - Possibilidades de classificação segundo a diversificação do portfólio, estratégia de crescimento e modelo de negócio

A Etapa cinco 5 trata de consolidar as empresas em grupos, capazes de representar empresas que exerceram escolhas de portfólio e de crescimento equivalentes, e 
confrontar o desempenho de cada amostra com a média do conjunto das empresas e com outras amostras, representantes de outras escolhas e estratégias. Para tanto, foram empregados os indicadores de Margem Líquida e lucro sobre o Patrimônio Líquido, com o objetivo de determinar a capacidade de geração de renda e valor para o capital dos acionistas.

Por fim, a Etapa 6 trata da apresentação dos resultados, dicussões e considerações finais. 


\subsection{Amostra}

A pesquisa tem como amostra as companhias listadas no segmento Construção Civil do Novo Mercado da BM\&FBovespa.

De todas as empresas, foram excetuadas da pesquisa as companhias Inpar(Viver) e Direcional Engenharia. A primeira por não possuir as informações de empreendimentos em nível de detalhamento exigido para os cálculos dos índices de diversificação, e a segunda por ser a empresa mais recente, cujo histórico de informações é igualmente insuficiente.

As empresas Brascan, Company, Agra, Klabinsegall, Abyara e Tenda tiveram suas estratégias analisadas e indicadores de diversificação determinados, porém não Figuraram nos cálculos de desempenho devido ao curto histórico e à descontinuidade das informações financeiras, haja vista os processos de fusão ocorridos no período.

A empresa JHSF, por possuir empreendimentos destinados para renda em seu portfólio, teve sua diversificação e modelos de negócios analisados, porém não foi objeto de análise de desempenho.

Assim, para fins de comparação entre os indicadores de desempenho e os atributos destacados, foram utilizadas as seguintes empresas: Rodobens, Cyrela, Gafisa ,Rossi, PDG, Brookfield, MRV, CR2, Tecnisa, Helbor, CCDI, Trisul, Even e Eztec.

\subsection{Base de dados}

Foram identificados 2.890 registros, correspondente a empreendimentos lançados entre o período 2005 a 2010.

Para todas as empresas, com exceção da PDG, ROSSI e MRV, foram obtidos e identificados todos os empreendimentos por meio de informações disponíveis nos documentos oficiais das companhias. 
Para as empresas supracitadas, devido à ausência de informações em nível de empreendimento, para a PDG e ROSSI no ano de 2010 e para a MRV a partir de 2008, e com o objetivo de determinar a diversificação municipal, foram realizadas estimativas com base nas melhores informações disponíveis. Para tanto, havendo a relação dos municípios objeto de lançamento, o autor rateou o volume estimado de venda de cada estado pelo número de habitantes de cada município objeto de lançamento.

As empresas Brascan, Company, Abyara, Agre e Agra, devido ao curto histórico de informações, igualmente foram descartadas da análise de desempenho.

\subsection{Limitações}

Os resultados desta pesquisa devem ser interpretados com as seguintes ressalvas:

- a amostra utilizada é pequena frente ao universo das empresas de Real Estate, pois representa apenas as empresas de capital aberto listadas na BM\&FBovespa;

- o desempenho econômico empresarial está sujeito a diversas outras variáveis que não foram consideradas no estudo, tais como estratégias de marketing, vendas, relacionamento com clientes, entre outras;

- considerando que parcela expressiva dos empreendimentos destinados para baixa renda foi lançada no ano 2010, os resultados destes empreendimentos ainda não foram reconhecidos pelos balanços atualmente disponíveis;

- estratos de mercado não se classificam somente nas delimitações municipal, mesoregional e estadual; classificam-se também por bairros. Assim, as empresas podem ser diversificadas para mais ou para menos do que o nível identificado;

- a estratificação dos produtos teve como critério o preço médio das unidades do empreendimento, tratando-se, portanto, de aproximação; 


\section{DIVERSIFICAÇÃO DO PORTFÓLIO DE EMPREENDIMENTOS E MERCADOS EM EMPRESAS DE REAL ESTATE}

O presente capítulo tem como objetivo posicionar o leitor ao tema de fundo da dissertação. Serão apresentados os principais conceitos relacionados ao tema estratégia empresarial, diversificação de produtos, mercados e estratégias de crescimento, sempre no âmbito das empresas de Real Estate.

\subsection{Concentração e diversificação em empresas de Real Estate}

Do ponto de vista econômico, o objetivo estratégico de qualquer organização empresarial é remunerar o capital dos acionistas. No ambiente das empresas de Real Estate, este objetivo é buscado por meio do investimento em produtos com lastro imobiliário.

Investir em empreendimentos de Real Estate, especificamente para as empresas com foco nos segmentos residencial e comercial para venda, significa imobilizar recursos por um longo período, com o objetivo de gerar riqueza por meio das atividades de construção e venda de unidades imobiliárias.

A capacidade de geração de riqueza do empreendimento é determinada pela velocidade de inserção do produto no estrato de mercado alvo, ao patamar de preço e meio de pagamento suficiente para remunerar o investimento em nível almejado.

De maneira análoga, a capacidade de geração de riqueza de uma empresa de Real Estate é determinada, excetuando fatores macroeconômicos e setoriais, por sua competência em formular, fazer e "girar" um portfólio de empreendimentos competitivos, cujas relações de qualidade do produto e preço provoquem a sua inserção de mercado a preços e a fluxo de recebimentos suficientes para remunerar o capital investido no patamar desejado. 
Neste sentido, o desafio da empresa de Real Estate deve ser formular e executar empreendimentos com margens adequadas para o padrão de rentabilidade desejado, e encaixar novos empreendimentos em seu portfólio, em velocidade cujos recursos livres provenientes dos empreendimentos finalizados sejam eficientemente reinvestidos em outros.

Formular empreendimentos requer conhecimentos de mercado, dos hábitos e anseios do público-alvo, com o objetivo de formatar e inserir no mercado alvo empreendimentos com patamar de preço-qualidade que atendam a remuneração almejada.

Executar empreendimentos requer competências de produto, engenharia, processos e gestão, com o objetivo de controlar custos e manter o orçamento nos limites previstos. Igualmente à formulação, requer também conhecimentos locais, principalmente de âmbito da aprovação nas esferas públicas competentes e acesso a serviços especializados que possam agregar valor ao produto.

$\mathrm{Na}$ realidade cotidiana, as empresas e empreendimentos estão imersos dentro do ambiente setorial e competitivo, sujeitos a perturbações de ordem externas e internas à empresa, cujos impactos podem provocar revisões das estratégias das companhias, resultando na busca por novos produtos ou mercados.

Ansoff (1977) denomina como componentes da estratégia o conjunto de decisões formadas pela definição dos produtos e mercados, crescimento e vantagem competitiva da empresa. A partir do momento que uma empresa vislumbra oportunidades de rentabilidade em produtos e mercados distintos aos do seu campo de atuação, e decide por entrar, a empresa formula estratégias para persegui-los, de modo a proporcionar aos acionistas a remuneração vislumbrada, a riqueza intrínseca do novo produto ou mercado. No entanto, não havendo vantagem competitiva da empresa no novo mercado ou produto, em relação às empresas concorrentes, a riqueza efetiva, real, da companhia será menor do que a riqueza intrínseca ao negócio. À capacidade da empresa em aproximar a riqueza intrínseca em riqueza real, ou em gerar vantagem competitiva, Ansoff (1977) denomina "sinergia". 
Em termos das escolhas de produtos, as empresas de Real Estate podem optar por empreendimentos destinados para geração de renda ou venda. $\mathrm{O}$ primeiro foge do escopo da presente dissertação, e tem como objetivo a geração de renda ancorada na operação de produtos imobiliários. A segunda, foco das empresas objeto de estudo da dissertação, tem como objetivo a geração de riqueza durante o ciclo de implantação do empreendimento, e se destina, em geral, para os segmentos residencial e comercial.

Dentro dos segmentos comercial e residencial, há ainda estratificações baseadas em hábitos e anseios comuns a grupos de indivíduos, cujas características, demandas e anseios do público alvo são diferentes a ponto de demandar diferentes produtos e competências para a formulação e execução dos empreendimentos.

No vetor mercado, encontram-se as estratificações de públicos alvo baseadas em suas proximidades geográficas, e quanto menor a delimitação territorial que a empresa busca atuar, presume-se mais fácil a identificação dos estereótipos, hábitos e anseios do público alvo.

A escolha estratégica dos produtos e mercados implica no desenvolvimento de competências para a formulação de empreendimentos destinados para estes fins. Quanto menor a competência da empresa no atendimento dos objetivos formulados na estratégia, menor será sua capacidade de transformar riqueza intrínseca em riqueza real.

Assim, quanto maior o portfólio de produtos e mercados da empresa, maior deverá ser o seu portfólio de competências.

Tem-se, neste caso, fatores de ordem negativa para as companhias que optam por portfólios diversificados de produtos e mercados.

O primeiro, intrínseco a todas as empresas, trata do problema de adquirir os melhores recursos com as competências necessárias para o desenvolvimento de portfólio de empreendimentos destinados a um produto-mercado específico. Trata-se do problema de "saber fazer" e "fazer melhor", e está relacionada à vantagem competitiva da organização frente às empresas concorrentes. 
O segundo trata da dificuldade em comunicar adequadamente uma estratégia clara da empresa, para os próprios gestores, organização e mercado, o que pode implicar em profissionais menos eficientes e, inclusive, no valor de mercado da própria.

Uma companhia que decide por um portfólio diversificado de produtos pode optar por possuir uma tipologia de recursos de competência genérica, ou $n$ recursos de competências especializadas.

A primeira alternativa implica em reduzir a capacidade da empresa em "saber fazer" e "fazer melhor" empreendimentos, que poderá levar a produtos menos competitivos e, consequentemente, menor capacidade da empresa em transformar a riqueza intrínseca ao empreendimento em riqueza real.

A segunda alternativa implica em aumentar a capacidade da empresa em "saber fazer" e "fazer melhor" o empreendimento, no entanto, pode resultar em ineficiências em nível de empresa, tendo em vista a complexidade do gerenciamento de negócios distintos e a sobreposição de atividades.

Uma empresa que opta pela diversificação de mercados incorre em desafios semelhantes. Competência de mercado demanda em conhecer o local, a cultura, os hábitos e anseios dos públicos alvo, as partes interessadas, os fornecedores e os prestadores de serviços; sobretudo, demanda também ser conhecido. Neste caso, segundo levantamento do autor, quatorze empresas ${ }^{11}$ do setor declararam, no momento de suas aberturas de capital na BM\&FBovespa, possuírem como vantagem competitiva o valor de suas marcas corporativas.

Estar presente em diversos produtos e/ou mercados implica em menor exposição a riscos em nível local, relacionados à super oferta de produtos em estratos específicos, ou de ordem conjunturais, tais como acesso ao crédito para aquisição, que poderá afetar a capacidade de pagamento pelo produto e, consequentemente, sua demanda.

\footnotetext{
${ }^{11}$ Helbor, Eztec, Inpar(Viver), JHSF, Tecnisa, CCDI, Rodobens, Brascan, KlabinSegall, Abyara, Company, Cyrela, Gafisa e Rossi.
} 
As empresas brasileiras atualmente especializadas nos segmentos de baixa renda, especificamente aos produtos financiados pelo programa Minha Casa Minha Vida, certamente sabem inserir empreendimentos competitivos para baixa renda com maior competência do que as empresas diversificadas. No entanto, eventuais descontinuidades do programa poderão impactar igualmente sua demanda.

Empresas diversificadas podem possuir maior capacidade de reinvenção, acesso a oportunidades e flexibilidade, ainda que esta última dependa também do modelo de negócio empregado pela organização, a ser discutido no capítulo cinco.

Escolher portfólios de produtos e mercados implica também em decidir na estratégia organizacional da empresa em como realizar o portfólio. Decidir em entrar em novos produtos ou mercados significa agregar novas competências para a companhia.

Empreender nos segmentos de baixa e alta renda demanda competências mais contundentes do que empreender para a média renda.

Segundo Rocha Lima Jr (2009), em análise da qualidade do investimento em empreendimento protótipo destinado ao segmento de renda de quatro salários mínimos, empreendimentos destinados para a baixa renda possuem capacidade de produzir resultados dentro dos padrões desejados para o empreendedor. No entanto, demandam planejamento do produto e gestão intensiva de custos. A compra de terreno adequado e a gestão de produtos em escala são fatores determinantes no desempenho do empreendimento.

A limitação da capacidade de pagamento do público de baixa renda implica em limitações de preço e condições de pagamento, e a inflexibilidade do produto e os custos da construção civil conferem ao empreendimento de baixa renda menores margens de erro para o empreendedor, uma vez que o repasse da ineficiência do empreendimento para o preço torna-se limitado.

A menor margem para erro implica no empreendedor buscar competências de produtos, de processos de engenharia e de gestão de projetos, com o objetivo de manter os custos sob os níveis planejados. 
O custo da terra também é determinante. Adquirir terrenos a preços adequados, localização e característica são atributos fundamentais para produzir margem de resultado no empreendimento. Localização e características de dimensão e topográfica adequadas permitem, respectivamente, agregar valor, permitir a produção de empreendimentos em escala e reduzir os custos com a adaptação do terreno.

Apesar de vender para a baixa renda significar, em alguns casos, demanda garantida por meio de cadastros de programas habitacionais, implica em ter canal e bom relacionamento com o agente financiador, que, por sua vez, pode dar preferência para empresas com grandes volumes de contratações financeiras. Assim, empreender para baixa renda, do ponto de vista de venda, implica em ter volume de produção e bom relacionamento com o agente financeiro.

No outro extremo, empreendimentos destinados para alta renda possuem maior capacidade de repasse de custos para os preços e, portanto, maiores margens de erro por parte do empreendedor. Demandam, no entanto, conhecimento específico dos elementos que agregam valor ao empreendimento, relacionados aos hábitos $\mathrm{e}$ exigências do público alvo.

Empreendimentos para alta renda demandam estratégias de venda diferenciadas e personalizadas, serviços de acabamento e diferenciais 


\subsection{As estratégias de crescimento}

As decisões de produtos e mercados, quando dispostas na matriz (Figura 4), conFiguram tipos de estratégias de crescimento, com características e riscos diferentes.

Segundo Ansoff (1977), na estratégia de penetração de mercado, a empresa orienta o seu crescimento para os produtos e mercados já conhecidos. Não há, neste caso, afastamento de suas competências. O vetor expansão caracteriza-se pelas estratégias de desenvolvimento de mercados e desenvolvimento de produtos. Na primeira, a empresa busca novos mercados para os produtos existentes. Na segunda, a empresa cria novos produtos, em substituição ou complementação, para os mercados existentes. Por fim, a diversificação caracteriza-se pela criação de novos produtos em novos mercados

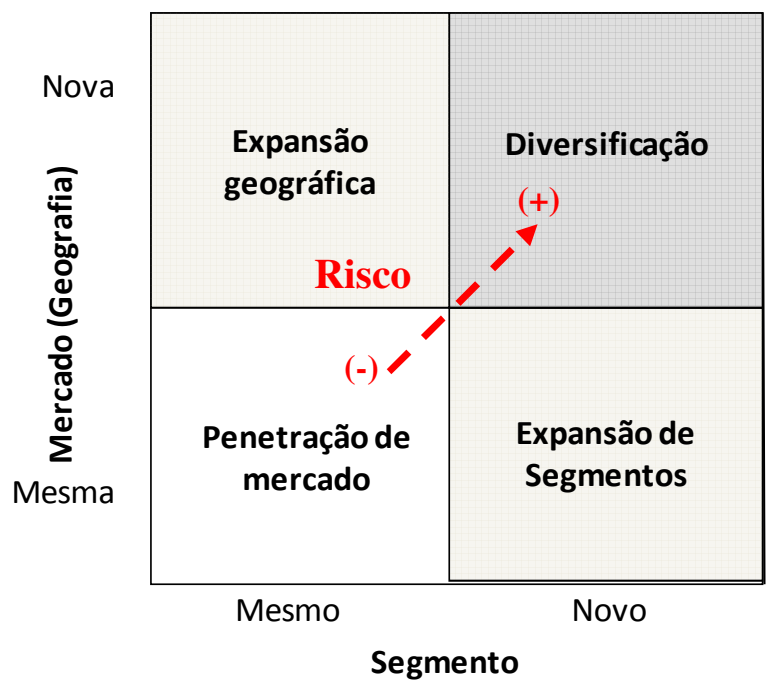

Figura 4 - Matriz de Diversificação do Portfólio de Negócios de empresas de Real Estate Fonte: ANSOFF (1977), HEWLETT \& KAUFMANN (2008). Adaptado. Tradução própria

De acordo com o autor, a "sinergia", ou a riqueza efetivada pela companhia, deverá ser superior quando a empresa expande suas atividades, ao invés de diversificar. Assim, segundo o mesmo autor, significa dizer que se uma empresa puder atingir todos os seus objetivos sem a diversificação, melhor. Uma vez esgotada todas as possibilidades dentro dos limites internos à empresa ou dos mesmos produtos e mercados, a empresa deverá pensar em diversificar-se. 
A expansão de produtos e mercados foi tendência nos últimos cinco anos do setor de Real Estate brasileiro, especificamente para as empresas que abriram capital na BM\&FBovespa. Segundo levantamento realizado pelo autor nos prospectos de abertura de capital das companhias, os principais motivos declarado pelas empresas para a diversificação geográfica (de mercados) e segmentos de renda (de produtos) foram a busca por novas oportunidades de negócios rentáveis e canais de crescimento, em mercados e produtos que apresentassem sinais de forte demanda.

Destaca-se também a busca da flexibilidade pelas empresas. As companhias, sabendo que as perturbações e os desvios de estratégias são inerentes a qualquer empresa, buscam mecanismos que possibilitem à empresa adaptar-se rapidamente às novas condições do ambiente competitivo.

Os objetivos de rentabilidade, crescimento e flexibilidade são vetores, no âmbito das empresas de Real Estate, formulados por Rocha Lima Jr (1994). Segundo o autor, as empresas do setor, no sistema de planejamento estratégico, devem buscar a manutenção de um estado de equilíbrio sustentável na relação empresa para com o seu ambiente. Assim, deverão ser formuladas diretrizes que busquem (1) a manutenção de certo padrão de rentabilidade para a ação da empresa, (2) o reconhecimento de um canal de crescimento no mercado em que está inserida e, (3) permitir que a empresa possa agir com o melhor nível de flexibilidade na sua inserção de mercado.

Do ponto de vista das escolhas de portfólio versus o vetor de rentabilidade, quanto maior o número de mercados e produtos atuados, maior deverá ser a probabilidade de a empresa acessar oportunidades de negócios "rentáveis". No entanto, maior a dificuldade em maximizar a "sinergia", ou seja, transformar a riqueza intrínseca ao negócio em riqueza para a companhia, dada a complexidade do gerenciamento do portfólio de competências.

Do ponto de vista do canal de crescimento, quanto maior o número de produtos e mercados operados pela companhia, igualmente maior deverá ser a probabilidade de identificar mercados com alta demanda. 
A diversificação da empresa pode ser benéfica para o atendimento da flexibilidade, ao permitir que a empresa possua experiência em diversos mercados e produtos. No entanto, possui mais relação com o modelo de negócio da empresa do que com a diversificação do portfólio propriamente dita.

Se a empresa opta por acessar diversos produtos e mercados por meio de competências de terceiros, via alianças estratégias, o menor custo de saída de produtos e mercados agrega maior flexibilidade para a empresa. No entanto, se a empresa opta por formar recursos internos dedicados, dois são os fatores negativos: o primeiro diz respeito ao recurso genérico, com pouca especialização, cuja competência será provavelmente insuficiente para o atendimento da "sinergia". O segundo, caso a empresa opte por ter um portfólio especializado de competências, diz respeito à empresa possuir maiores custos de saída no caso da descontinuidade de negócios e, portanto, menor flexibilidade.

Caso as empresas não possuam as competências para atuação nos novos mercados e/ou produtos, e necessitam acessá-los em tempo hábil, é comum no setor e na economia como um todo as organizações firmarem alianças estratégicas com empresas concorrentes, conforme será abordado com maiores detalhes no capítulo cinco. 


\section{ALIANÇAS ESTRATÉGICAS}

O presente capítulo tem como objetivo discorrer sobre os principais modelos de parcerias entre organizações empresariais, suas motivações, e contextualizá-las no setor de Real Estate brasileiro no período 2006-2010.

Alianças estratégicas podem ser definidas como qualquer acordo entre firmas, por meio dos quais as partes visam atingir objetivos estratégicos previamente estabelecidos (DAS e TENG, 1996). As parcerias, joint ventures, e fusões e aquisições são todos conceitos de alianças estratégias, e diferem entre si no grau de integração e interdependência entre as empresas (LORANGE \& ROOS, 1993).

As alianças estratégicas entre empresas são comuns, e podem se dar entre organizações que estejam no mesmo nível da cadeia de suprimentos, as chamadas alianças horizontais, ou em níveis distintos, as alianças verticais.

Durante o levantamento das alianças estratégicas firmadas pelas empresas do setor, conforme pesquisa realizada pelo autor, foram identificados casos de alianças estratégicas entre empresas incorporadoras com corretoras e bancos, com vistas ao financiamento das unidades imobiliárias quando prontas. O principal, no entanto, foram as alianças horizontais, firmadas com o objetivo de entrar em novas regiões geográficas ou segmentos de renda.

Em estudo de caso realizado no mercado imobiliário da cidade de São Paulo, BatalhaVasconcelos (2008) identificou diversas alianças estratégicas horizontais firmadas entre as empresas do setor, em diversos níveis contratuais e formais, sendo mais comuns aquelas firmadas no ambiente do empreendimento. Os tipos identificados são apresentados na tabela abaixo. 
Tabela 1 - Tipos de alianças estratégicas horizontais na incorporação imobiliária da cidade de São Paulo

\begin{tabular}{|l|l|}
\hline \multirow{5}{*}{$\begin{array}{l}\text { Alianças horizontais - Gestão } \\
\text { compartilhada }\end{array}$} & Acordo informal \\
\cline { 2 - 2 } & Acordo formal \\
\cline { 2 - 2 } & Contrato de parceria \\
\cline { 2 - 2 } & Consórcios \\
\cline { 2 - 2 } & Co-incorporação \\
\cline { 2 - 2 } & $\begin{array}{l}\text { Sociedade de Propósito Específico (joint } \\
\text { venture })^{12}\end{array}$ \\
\hline
\end{tabular}

Fonte: Batalha-Vasconcelos, 2008. Adaptado

Em estudo de caso realizado no mercado imobiliário da cidade de Salvador-BA, Avelar e Monteiro (2007) identificaram diversas formatações de alianças realizadas por empresas concorrentes. Entre as alianças, destacam-se as alianças que se dão no ambiente do empreendimento, por meio da divisão ou partilha de responsabilidades entre as atividades de aquisição de terreno, construção e gerenciamento da incorporação, ou parcerias de maior prazo em nível da empresa, formalizadas contratualmente em nível de empreendimento para cada nova incorporação.

Nota-se, em ambas as pesquisas o predomínio de alianças formais realizadas no ambiente dos empreendimentos, estando estas respaldadas ou não por acordos bilaterais em nível das empresas.

Segundo informações levantadas pelo próprio autor, foram firmadas oitenta e quatro parcerias entre as empresas de capital aberto na BM\&FBovespa e empresas menores, com o objetivo de expandir para novos produtos ou mercados. O número de alianças por tipo encontra-se no Gráfico abaixo, e a relação de todas elas no Apêndice E.

\footnotetext{
${ }^{12}$ A autora classifica joint ventures como associações realizadas no ambiente do empreendimento. O presente trabalho, como se verá adiante, adotou o termo parcerias para as associações firmadas no ambiente da SPE e joint ventures as firmadas no ambiente das empresas.
} 


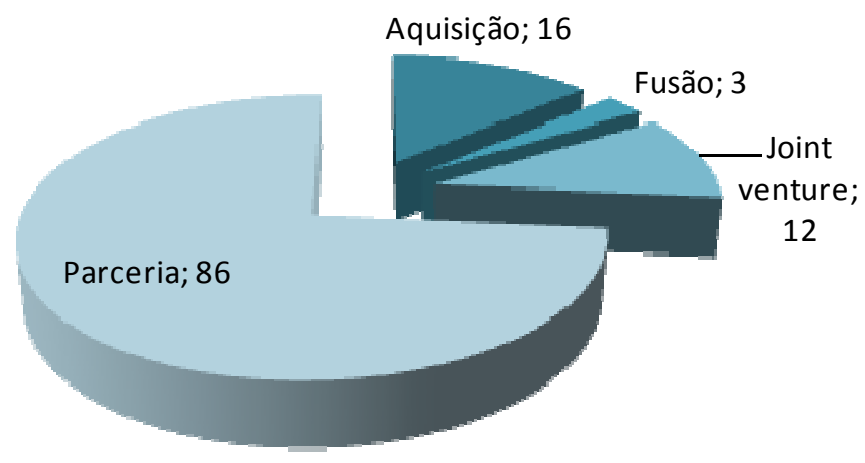

Gráfico 5 - Número de alianças estratégicas por tipo firmadas pelas empresas do segmento construção civil da BM\&FBovespa no período de 2006 a 2010.

Fonte: Elaboração do autor

Dentre as aquisições, destacam-se as realizadas pela PDG para entrada em novos produtos e mercados, através da aquisição das empresas CHL, Goldfarb, Cipasa e, ao final de 2010, a aquisição da AGRE.

Para entrada no segmento econômico e acesso a terrenos no interior do estado de São Paulo, a CCDI adquiriu o grupo HM engenharia e construções.

A Gafisa adquiriu a Tenda, incorporadora de capital aberto com foco no segmento popular.

Como estratégia de expansão de mercados, a fusão entre as empresas Company e Brascan e, posteriormente, a aquisição da empresa MB engenharia, permitiu ao grupo acessar número expressivo de mercados em curto intervalo de tempo.

As organizações formulam alianças estratégicas segundo diversos motivos, com destaque para o objetivo de absorver competências e recursos que a empresa não possui, com vistas a desenvolver novos produtos; ou quando a empresa almeja entrar em novos mercados, incertos, procurando se proteger por meio do compartilhamento de riscos. (KOGUT, 1989 apud KUMAR, 2005)

No primeiro caso, a alternativa à aliança estratégia é o desenvolvimento interno de competências, ou crescimento orgânico, conforme denominação de algumas empresas 
do setor. Nestes casos, ao invés de a empresa buscar competências em terceiros, seja por via de parceria, joint venture ou aquisição, ela empresa opta pela alocação de equipe dedicada, com programas de qualificação e contratação de profissionais específicos.

A segunda tem como objetivo a entrada gradual em novos mercados vistos ainda como incertos, por meio do compartilhamento de riscos com o parceiro. A aliança é um meio para melhor conhecer e entender o novo mercado, bem como o próprio parceiro, que poderá ser objeto ou não de aquisição no futuro.

Tendo em vista as diversas definições de alianças estratégicas identificadas, a presente dissertação fez uso das definições relacionadas na Tabela abaixo, adaptadas, com o objetivo de delimitar os conceitos a serem utilizados ao longo do trabalho. 
Aliança

Acordo formal ou Termo de compromisso

Parceria

Parceria

Joint venture

Aquisição

Fusão
Definição

Quando duas ou mais empresas formalizam um protocolo de intenções, com vistas à realização conjunta de empreendimentos imobiliários.

Quando duas ou mais empresas atuam em sociedade na incorporação de um determinado empreendimento, sem que haja a constituição de joint venture entre as mesmas, independente se houve ou não prévia assinatura de termo de compromisso entre as partes. A sociedade é constituída no ambiente da sociedade de propósito específico do empreendimento, e não no nível da empresa.

Quando duas ou mais empresas constituem uma nova figura jurídica com um objetivo em comum.

Quando uma empresa adquire posição majoritária no capital de outra empresa.

Quando duas ou mais empresas decidem fundir suas estruturas de capital, formando uma única entidade jurídica.

Figura 5 - Definições por tipos de alianças estratégicas.

Fonte: elaboração do autor. Adaptado de PALMA (2006), LORANGE \& ROOS (1993)

Acordos informais, dado o baixo grau de comprometimento entre as partes e a difícil identificação, não foram considerados casos de aliança estratégica e, portanto, suprimidos do presente trabalho.

Por fim, as parcerias podem possuir diversas formatações, níveis de responsabilidade e integração entre as empresas. 
No âmbito das companhias de Real Estate, as parcerias horizontais em nível empresa, ou acordos formais, ou ainda termo de compromisso, são geralmente firmadas com o objetivo de prospecção e direito de preferência na co-incorporação de futuros empreendimentos imobiliários, por parte da empresa de maior porte ${ }^{13}$, em empreendimentos prospectados pela empresa local. Nestes casos, a empresa local se compromete a oferecer para a outra parte determinado volume de empreendimentos pré-estabelecido.

Os acordos operacionais não envolvem aporte de capital, e em geral, mas não necessariamente, precedem as parcerias em nível de empreendimento.

São exemplos de acordos operacionais as parcerias firmadas pela CCDI (Camargo Corrêa Desenvolvimento Imobiliário) com as empresas Lix da Cunha, da região da Campinas-SP, e com a empresa Kallas Incorporações e Construções.

Em nível de maior intensidade estão as alianças que envolvem aporte de capital. Nestes casos, Figuram as parcerias em nível de empreendimento, cuja sociedade se dá pela participação das empresas na sociedade de propósito específico dos empreendimentos.

Segundo pesquisa realizada pelo próprio autor, as parcerias realizadas pelas empresas maiores tiveram como objetivo, na maioria dos casos, a expansão geográfica.

A configuração da parceria pode ser diversa, cabendo entre as partes a definição de suas responsabilidades no empreendimento. É comum, no entanto, que a empresa local possua terreno e conhecimento do mercado, faltando, porém, capital para construção e porte para aquisição de linhas de financiamento, competências presentes nas empresas maior que, por sua vez, não possuem o terreno e o conhecimento do mercado local.

Figura-se, portanto, formatação da parceria conforme Figura abaixo.

\footnotetext{
${ }^{13}$ MAIOR faz referência às grandes incorporadoras que abriram capital na BM\&FBovespa. [LOCAL] faz referência as empresas de menor porte, de atuação geográfica localizada, procuradas pelas empresas MAIOR para alianças estratégicas, com o objetivo de expandir mercados.
} 
Cria-se uma entidade para o empreendimento, a partir de uma sociedade de propósito específico, onde a empresa local aporta terreno, construção e gerenciamento da obra. Por outro lado, a empresa maior aporta investimento e gestão.

Um contrato de consórcio entre as partes pode ser constituído, com o objetivo de gerir o empreendimento e as sociedades de propósito específico, cabendo em geral à liderança por parte da empresa maior.

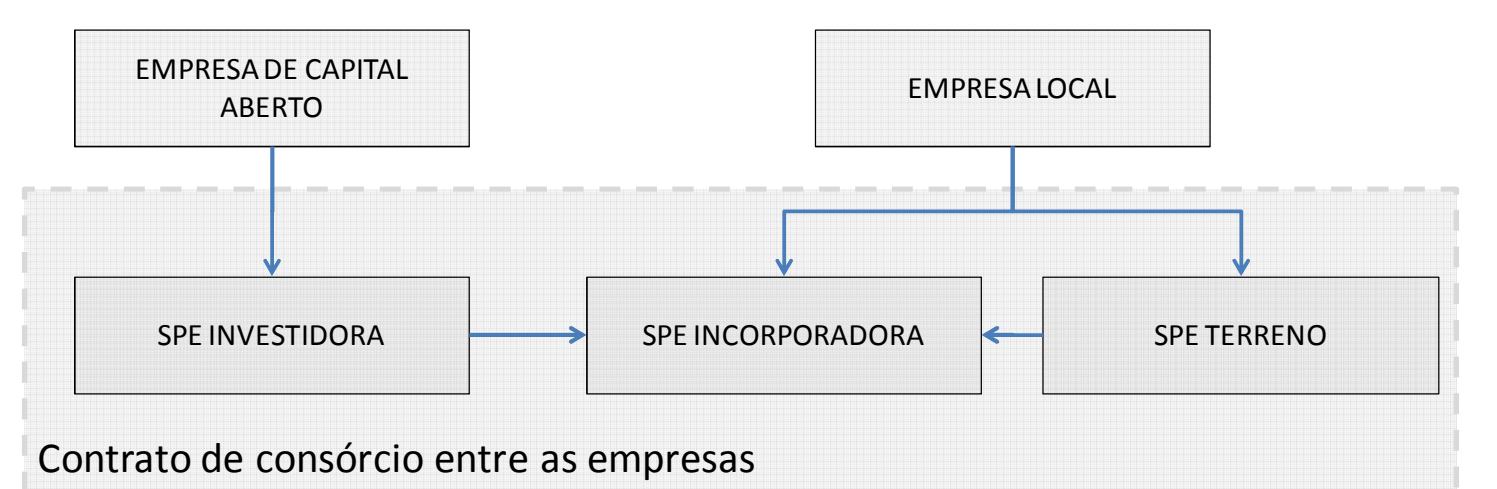

Figura 6- Modelo de negócio de parcerias usualmente empregado para as estratégias de expansão geográfica.

Fonte: elaboração do autor 


\subsection{Alianças estratégicas como meio de crescimento e diversificação}

As organizações, ao vislumbrarem oportunidades de crescimento, podem interessar-se por novos produtos e/ou mercados, cujo desconhecimento associa-se a incertezas perante o seu desenvolvimento. Neste contexto, segundo Kogut (1998) apud Kumar (2005), as alianças estratégicas podem ser um meio de diluir riscos e permitir a aquisição de conhecimentos e competências de maneira gradual, até que a empresa tenha melhores condições de decidir por ampliar sua participação no negócio, ou mesmo sair.

A mesma estratégia é citada por Williamson (1996), ao afirmar que as alianças podem atuar como estrutura de transição em processos de crescimento das organizações. Antes de aplicar quantidades significativas de capital em novos mercados, as empresas podem, por meio das associações, adquirir maiores informações e criar, de maneira gradual, os recursos e competências necessárias para o desenvolvimento do negócio.

Segundo o mesmo autor, se o objetivo final é a aquisição do parceiro, a aliança pode ser um importante mecanismo de valuation, ao expor durante as atividades operacionais suas forças, fraquezas, recursos e competências.

Para Lynch (1990), a realização de parcerias ${ }^{14}$ e/ou fusões e aquisições são estratégias de crescimento e diversificação de empresas. Segundo o autor, a formação de parcerias requer que a empresa mobilize recursos importantes, que sejam capazes de gerenciar as alianças e absorver as habilidades e competências do parceiro.

Destaca-se aqui o conceito de portfólio de alianças, que, conforme Wassmer \& Dussage (2011), muitas empresas da atualidade não possuem uma ou poucas alianças, mas sim múltiplas com diferentes parceiros com o objetivo de acessar um espectro variado de recursos.

Segundo Vassolo et al. (2004) apud Wassmer \& Dussage (2011), um ponto chave de um portfólio de alianças está na sua criação de valor para a empresa, cujo montante

\footnotetext{
${ }^{14} \mathrm{O}$ autor utilizou o termo aliança estratégica
} 
deve ser superior à soma dos valores individuais de cada aliança. Em estudo realizado pelos autores, concluíram que a relação entre os recursos das diversas alianças estratégicas é um fator fundamental para a criação de valor do portfólio.

Ao contrário das fusões e aquisições, as parcerias exigem pouco capital, além de serem mais flexíveis. Neste sentido, o autor exerce a mesma opinião dos outros citados na presente dissertação, ao afirmar que as parcerias podem ser utilizadas como um movimento de pré-aquisição, com o objetivo de melhor conhecer o futuro adquirido e o novo mercado.

\subsection{Alianças estratégicas como meio de absorção de conhecimento e vantagens competitivas}

Segundo Barney (1991) uma empresa possui vantagem competitiva sustentável quando esta adquire um estoque de recursos valiosos, raros, não imitáveis e não substituíveis. Tais recursos, por sua vez, podem ser adquiridos por meios internos, ou acessados por meio de alianças estratégicas com outras organizações.

Uma empresa não deve possuir um portfólio de produtos, mas sim um portfólio de competências, determinado pela capacidade de seus recursos, cuja relação com a criação de valor para a empresa é direta. Quanto maior o alinhamento dos objetivos da organização com seus recursos, maior sua capacidade, e maior seu potencial de geração de valor. (BARNEY, 1991)

Segundo Prahalad \& Hamel (1990), as competências são determinantes na liderança mercadológica da organização, sendo o desenvolvimento destes fatores essenciais para as empresas, obtidos por meio da retenção e acumulação de conhecimentos e habilidades ao longo de sua operação. Segundo o mesmo autor, a busca pela aquisição de novos conhecimentos é um dos fatores que motivam a realização de alianças entre empresas. 
Segundo Hamel (1991), a intenção, a transparência e a receptividade são importantes parâmetros que determinam a capacidade das empresas em reterem conhecimentos em alianças estratégicas.

A intenção diz respeito ao real objetivo da aliança, e maior será a capacidade da empresa em reter novos conhecimentos quanto maior tenha sido a intenção da retenção do conhecimento na formação da aliança.

A transparência refere-se à habilidade das partes no repasse e troca de informações. Segundo o autor, as alianças que carecem de processo de transparência entre as partes inviabilizam o fluxo de conhecimento entre as empresas.

Por fim, a receptividade é a própria capacidade de aprendizagem da empresa, sua cultura e ambiente organizacional. 


\section{5. ÍNDICES PARA MEDIDAS DE CONCENTRAÇÃO E DIVERSIFICAÇÃO}

O presente capítulo tem como objetivo apresentar índices usualmente empregados como medida de concentração de empresas ou setores produtivos, com vistas a prover elementos teóricos para o cálculo da diversificação das empresas.

Ao final do capítulo, todos os índices são aplicados em cinco empresas protótipo, com o objetivo de exemplificá-los.

Índices de diversificação são usualmente utilizados nas ciências biológicas e sociais, com o objetivo de calcular medidas de diversificação de espécies e populações. No âmbito das ciências humanas e econômicas, os índices são utilizados para cálculo de medidas de diversificação de empresas e setores econômicos. Entre as métricas identificadas, destacam-se as medidas de contabilização de negócios, o índice de entropia, o índice de especialização e os índices de concentração de mercados.

As medidas de contabilização são as mais simples, e mensuram a diversificação pela simplória contagem do número de produtos/negócios que a empresa possui atividade. Geralmente são baseadas em classificações estabelecidas por órgãos nacionais, ligados a agências e instituições governamentais (Pitts e Hopkins, 1982). No Brasil, sua equivalência seria o código da Classificação Nacional de Atividades Econômicas (CNAE) do IBGE. O índice possui diversas limitações; além de não permitir mensurar a diversificação de mercados (regiões geográficas), não considera a importância econômica relativa de cada negócio na empresa.

O índice de especialização (tradução livre de specialization ratio) foi proposto por Wrigley (1970) apud Rumelt (1974), e é calculado pela razão da receita do negócio predominante da empresa em relação à sua receita total - Equação 01. O índice tem como vantagem a possibilidade de considerar a contribuição de cada negócio na receita da companhia, porém limita-se ao não considerar o número de negócios existentes no portfólio da empresa. Assim, hipoteticamente, empresas que possuírem diferentes números de negócios e coincidentemente apresentarem igualdade na 
participação relativa do negócio predominante da organização, apresentarão o mesmo índice de especialização.

Rumelt (1974), a partir da lógica do índice de especialização, estruturou categorias de diversificação empresarial, hierarquizadas, com o objetivo posterior de estudar a influência de cada uma delas no desempenho econômico da organização. Para tanto, criou índices equivalentes, denominados quociente de relacionamento e quociente vertical, cujo objetivo, respectivamente, é determinar o grau de diversificação em negócios relacionais e verticais na cadeia de produção da indústria.

O índice de entropia (IE) foi desenvolvido por Palepu (1985) - Equação 02, e possui avanços em relação aos índices anteriores. O índice faz uma analogia ao conceito de entropia (grau de desordem de um sistema termodinâmico), e mensura a diversificação pela média ponderada da participação de cada negócio na empresa, onde o peso é o logaritmo neperiano do inverso da participação de cada negócio na organização.

Palepu (1985) deu continuidade à estruturação de Rumelt (1974), e criou, assim, índices de entropia para os negócios relacionados e não relacionados, sendo a soma de ambos o índice total de diversificação.

Por fim, os índices de concentração de mercados são utilizados para análise do grau de competitividade e monopólio de setores econômicos. Destaca-se o índice de Herfildahl, calculado por meio da raiz quadrada do somatório dos quadrados da participação de mercado de cada empresa em relação ao setor - Equação 03. Se aplicado à unidade da empresa, pode ser utilizado como métrica de diversificação empresarial. Além de o índice possuir as mesmas vantagens do índice de entropia, a métrica de Herfindahl é mais amplamente utilizada por agências e comissões federais em pareceres de fusões e aquisições que possam prejudicar a competitividade de seus setores econômicos, entre eles os Estados Unidos da América, Nova Zelândia, Austrália, União Européia e outros (Hausman e Sidak, 2007). 
$S R=$ máximo $\left[\frac{x_{i}}{X}\right]$, para $i=1$ a $n$

$I E=\sum_{i}^{n}\left[\frac{x_{i}}{X} \ln \frac{1}{\left(\frac{x_{i}}{X}\right)}\right]$

$H=\sum_{i}^{n}\left(\frac{x_{i}}{X}\right)^{2}$

, sendo $i$ o tipo de negócio (variando em número de 1 a $n$ negócios), $x$ a receita relativa a cada negócio $i$ e $X$ o somatório da receita de todos os negócios de uma organização.

Entre todos os índices supracitados, a presente dissertação optou por utilizar o índice de Herfindahl, por possibilitar, no cálculo do índice, tanto o número de mercados como a participação relativa de cada um no portfólio da empresa e ser amplamente utilizado por intuições antitruste, havendo, inclusive, referências de valores de índices para classificação dos mercados em concentrados, medianamente concentrados e não concentrados.

\subsection{0 índice de diversificação geográfica}

A presente seção tem como objetivo apresentar o método e critérios utilizados no cálculo da diversificação geográfica das empresas objeto de estudo da presente dissertação.

Para cálculo do índice de diversificação geográfica (IDG), empregou-se uma adaptação do índice de Herfindahl, conforme equação 4.

Tendo em vista que o índice de Herfindahl mensura o grau de concentração de uma unidade de observação $x$, geralmente empregada como sendo empresas pertencentes a um determinado setor econômico, e considerando o objetivo do índice aqui desenvolvido de calcular o grau de diversificação em nível empresarial, são feitas as seguintes considerações para cálculo do IDG: 
(1) As unidades de observação são regiões geográficas (mercados), e não empresas, conforme o índice é comumente utilizado;

(2) A importância de cada mercado é determinada pela soma do valor geral de venda de todos os empreendimentos contidos em seus limites, em relação ao valor geral de venda de todos os novos empreendimentos da empresa;

$I D G_{j, t}=1-H=1-\sum_{i}^{n}\left(\frac{V G V_{i, j}}{V G V_{j}}\right)^{2}$

, para o mercado (região geográfica) $i$, da empresa $j$, no período $t$.

O índice possui escala de 0 (zero) a $1-\frac{1}{n}$, e quanto maior o índice maior o grau de diversificação.

Para a delimitação das regiões geográficas, foram utilizadas as divisões territoriais de Municípios, Mesoregiões e Estados. Optou-se por três divisões territoriais, hierarquizadas, com o objetivo de propiciar a análise da diversificação geográfica em diferentes níveis territoriais.

Com o objetivo de caracterizar as empresas no início, ao longo e ao final do período de análise, os índices foram determinados considerando o portfólio de lançamentos ano a ano, entre 2005 a 2010, e consolidado para o período. 


\subsection{0 índice de diversificação de produtos}

A presente seção tem como objetivo apresentar o método e critérios utilizados no cálculo da diversificação de produtos das empresas objeto de estudo da dissertação.

Para cálculo do índice de diversificação de produtos (IDP), empregou-se uma adaptação do índice do Herfindahl, conforme equação já demonstrada, com as seguintes adaptações:

(1) as unidades de observação são produtos, e não empresas, conforme o índice é comumente utilizado;

(2) a importância de cada produto é determinada pela soma do valor geral de venda de todos os empreendimentos atribuídos ao seu tipo, em relação ao valor geral de venda de todos os novos empreendimentos da empresa;

Entende-se por produto um conjunto de empreendimentos com características de formatação e qualidade equivalentes, desenvolvido para um determinado público-alvo com anseios e capacidade de pagamento equivalentes entre si. Desta maneira, os produtos foram classificados segundo os segmentos de renda do público alvo, determinados pelo preço médio das unidades habitacionais, corrigidos para a moeda da base dezembro de 2010, utilizando como índice de correção o Índice Nacional de Preços ao Consumidor Amplo publicado pelo Instituto Brasileiro de Geografia e Estatística - IPCA-IBGE.

O índice de diversificação de produtos é representado pela equação abaixo.

$I D P_{j, t}=1-\sum_{s}^{n}\left(\frac{V G V_{s, j}}{V G V_{j}}\right)^{2}$

, para o segmento de renda $s$, da empresa $j$ no período $t$. 
Assim, as categorias de produtos foram definidas conforme Figura abaixo.

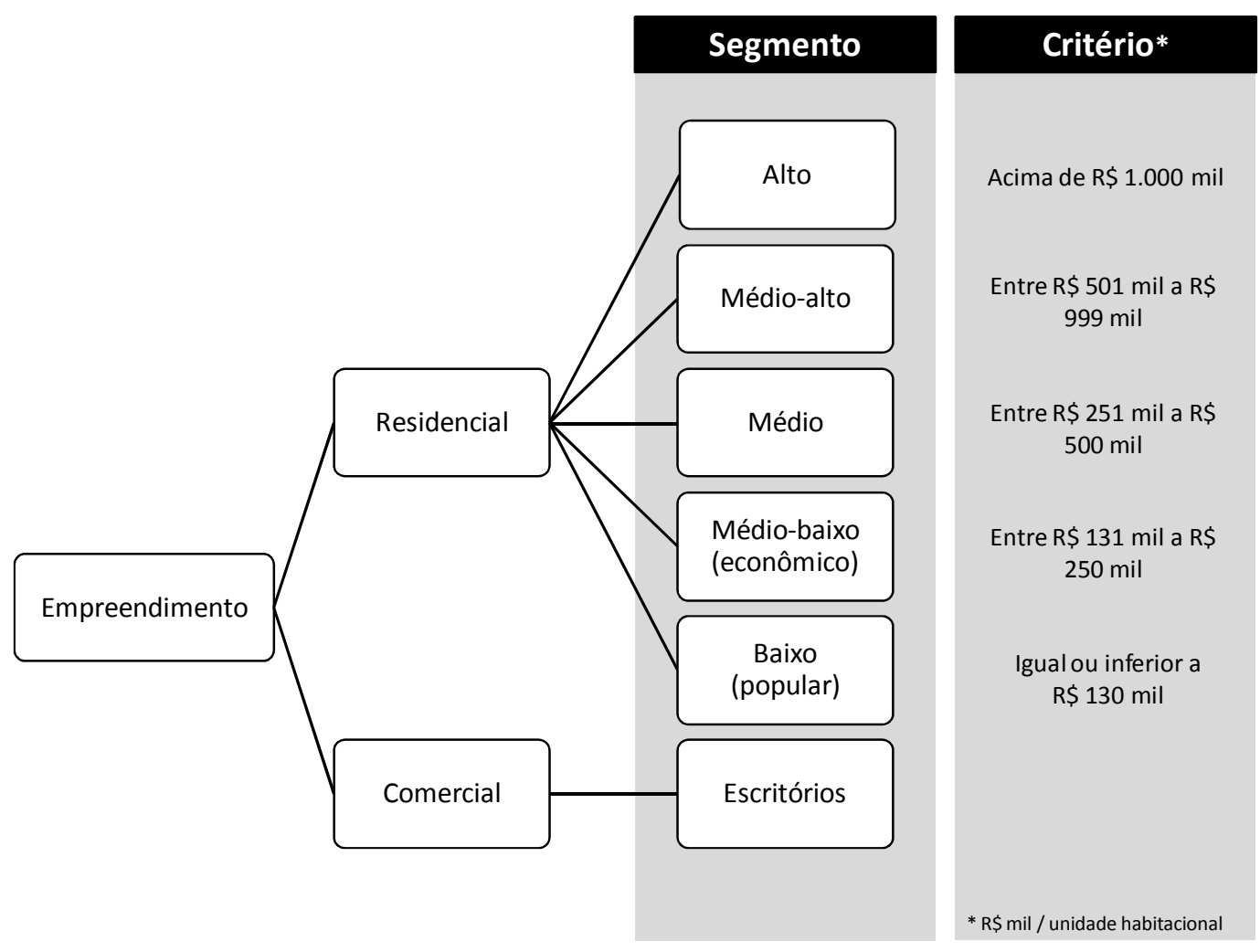

Figura 7 - Critérios e segmentos de mercados utilizados para classificação dos produtos/empreendimentos

Tendo em vista que as empresas atribuem nomenclaturas e critérios próprios para classificação de seus empreendimentos, a presente dissertação teve de padronizar os empreendimentos residenciais conforme critério único.

Desta maneira, foram determinadas faixas de preços por unidade habitacional, usando como referência a moeda da base (dezembro de 2010).

Para o segmento de baixa renda (popular), adotou-se o limite de até R\$ 130 mil por unidade habitacional, devido a este ser o limite do preço final para adesão ao programa federal Minha Casa, Minha Vida (MCMV), sendo critério para as empresas MRV, Tenda(Gafisa), Tecnisa, Brookfield e CR2, conforme apêndice D. 
Para a média renda, adotou-se o intervalo compreendido entre \$ 250 a R \$ 500 mil por unidade habitacional, conforme classificações das empresas Helbor, Brookfield, Tecnisa e Gafisa. O intervalo compreendido entre $\mathrm{R} \$ 130$ a $\mathrm{R} \$ 250$ foi denominado como segmento de média-baixa renda (econômico).

Os empreendimento acima de $\mathrm{R} \$ 1.000$ mil foram classificados como de alta renda, tendo uma vez que foi referência para as empresas Gafisa, CCDI, Brookfield e Helbor.

Os empreendimentos residenciais tipo loteamentos e não residenciais destinados para renda (shopping centers, lajes corporativas e outros), por possuírem estruturas de negócios diferentes e participação inexpressiva no portfólio de lançamentos das empresas objeto deste estudo, quando identificados, foram excluídos da base de dados. 


\section{CRITÉRIOS PARA CLASSIFICAÇÃO DAS EMPRESAS SEGUNDO A DIVERSIFICAÇÃO DO PORTFÓLIO DE EMPREENDIMENTOS, ESTRATÉGIAS DE CRESCIMENTO E MODELOS DE NEGÓCIOS}

Uma vez determinados os índices de diversificação geográfica por tipo de território, foram atribuídas às empresas as seguintes classificações demonstradas na Figura abaixo.
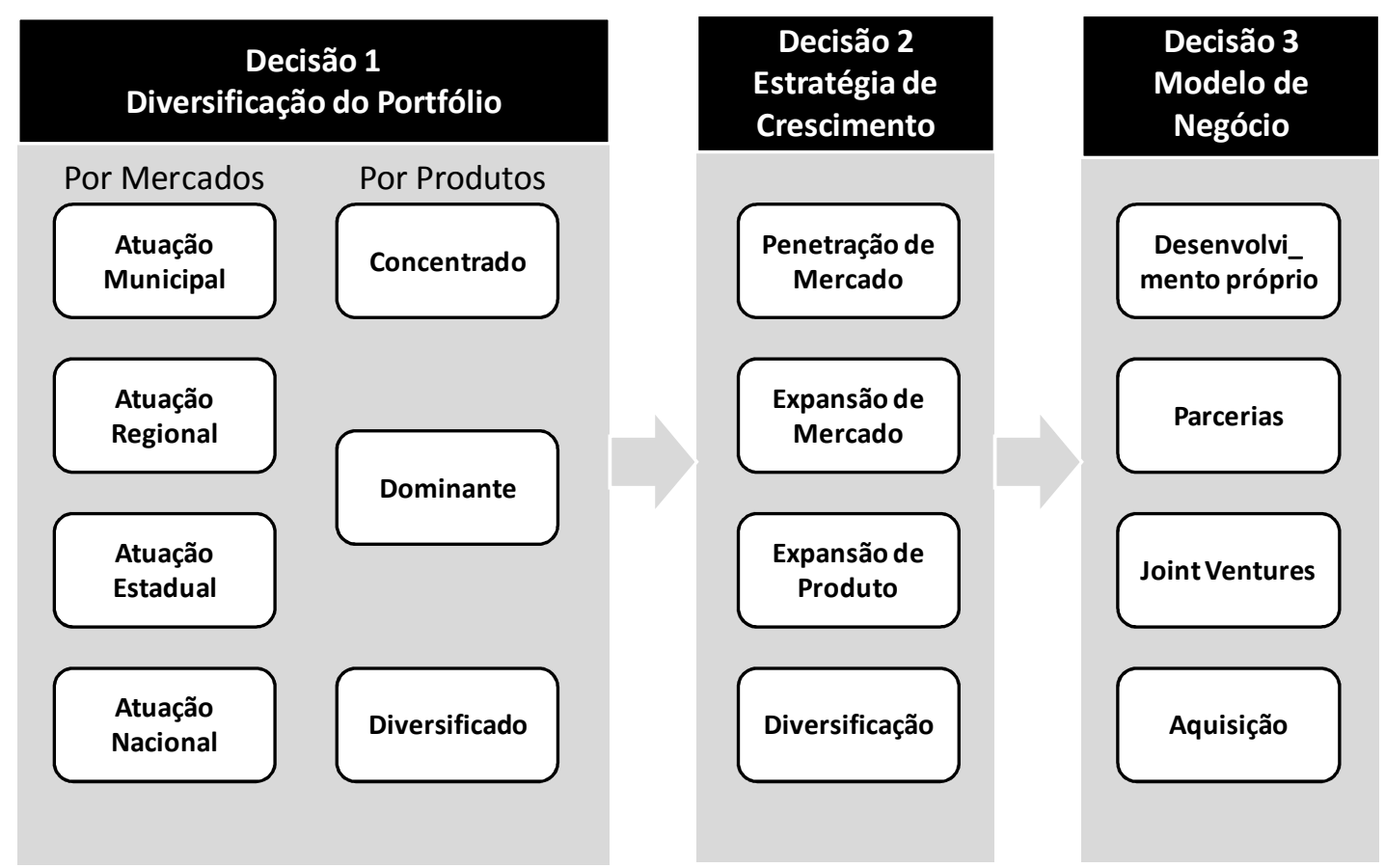

Figura 8 - Classificação das empresas segundo a diversificação do portfólio, estratégias de crescimento e modelos de negócios

Fonte: elaboração do autor

\subsection{Diversificação geográfica}

Para a classificação das empresas quanto à diversificação geográfica do portfólio de novos empreendimentos, foram empregados os seguintes critérios:

(1) os índices de diversificação municipal e mesoregional, atribuiu-se a classificação de concentrado para os índices que apresentaram valor igual ou inferior a 0,75 pontos; e diversificado para valores superiores. A fronteira de 0,75 pontos é referência utilizada pelo Departamento de Justiça e Comissão Federal do Comércio dos Estados Unidos (EUA, 2010) à escala 
do índice de Herfindahl. A comissão julga os pareceres de fusões e aquisições, com vistas a proteger mercados de monopólios. Será visto no item 7.4 que o índice de 0,71 utilizado significa atribuir como diversificada uma empresa que empreende para cinco ou mais territórios, uniformemente distribuídos em termos de volume estimado de venda.

(2) aos índices de diversificação estadual, devido à maior delimitação territorial e as diferenças sociais e culturais serem mais contundentes em relação às demilitações municipais e mesoregionais, atribuiu-se a classificação de concentrado para índices igual ou inferior a 0,5 pontos.

(3) às empresas que apresentaram concentração em todos os níveis territoriais, atribuiu-se a classificação de empresa de atuação municipal;

(4) às empresas que apresentaram diversificação municipal, e concentração nos demais níveis territoriais, atribuiu-se a classificação de empresa de atuação regional;

(5) às empresas que apresentaram diversificação mesoregional, e concentração no nível territorial, atribuiu-se a classificação de empresa de atuação estadual;

(6) às empresas que apresentaram diversificação em todos os níveis territoriais, atribuiu-se a classificação de empresa de atuação nacional.

\begin{tabular}{|c|c|c|c|}
\hline \multirow{2}{*}{ CLASSIFICAÇÃo } & \multicolumn{3}{|c|}{ CRITÉRIOS } \\
\cline { 2 - 5 } & $\begin{array}{c}\text { CONCENTRAÇÃO } \\
\text { MUNICIPAL }\end{array}$ & $\begin{array}{c}\text { CONCENTRAÇÃO } \\
\text { MESOREGIONAL }\end{array}$ & $\begin{array}{c}\text { CONCENTRAÇÃO } \\
\text { ESTADUAL }\end{array}$ \\
\hline Atuação Municipal & Concentrada & Concentrada & Concentrada \\
\hline Atuação Regional & Diversificada & Concentrada & Concentrada \\
\hline Atuação Estadual & Diversificada & Diversificada & Concentrada \\
\hline Atuação Nacional & Diversificada & Diversificada & Diversificada \\
\hline
\end{tabular}

Figura 9 - Critérios para classificação da diversificação geográfica.

Fonte: Elaboração do autor 


\subsection{Diversificação de produtos}

Para a classificação das empresas quanto à diversificação de produtos, atribuiu-se a categoria de portfólio especializado para empresas que apresentaram IDP menor que 0,56 ; portfólio dominante para empresas que apresentaram índices entre 0,56 e 0,71, e portfólio diversificado caso contrário, conforme fluxograma apresentado na Figura abaixo.

Os critérios foram arbitrados usando novamente o referencial do Departamento de Justiça e Comissão Federal do Comércio dos Estados Unidos (EUA, 2010). No entanto, foram reduzidos em $83 \%$ da escala da diversificação geográfica, tendo em vista que a escala máxima do IDP corresponde a $83 \%$ da escala do índice de Herfindahl, em razão de serem apenas seis mercados. A escala do índice de Herfindahl varia entre 0 (zero) a (1-1/n), conforme já exposto em capítulo anterior, sendo $n$ o número de mercados.

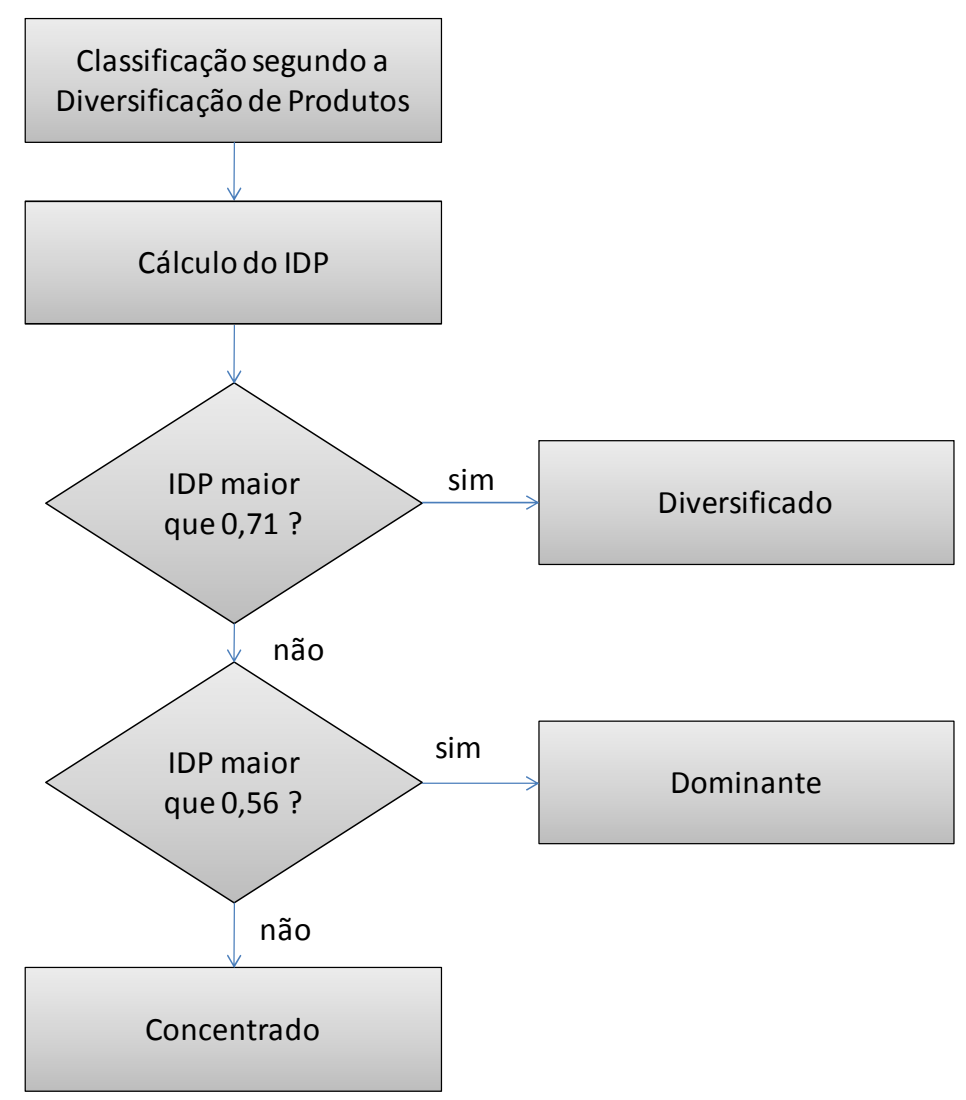

Figura 10 - Processo para classificação da diversificação de produtos. Fonte: elaboração do autor 


\subsection{Estratégias de crescimento e modelos de negócios}

Uma vez determinados os índices de diversificação geográfica e por produtos, e classificadas as empresas quanto à diversificação do portfólio de novos empreendimentos, foram identificadas as estratégias de crescimento adotadas por cada empresa, e os seus modelos de negócios predominantes.

Para a classificação das estratégias de crescimento, comparou-se a classificação e os índices de diversificação geográfica e de produtos das empresas nos anos 2006 e 2010.

Para as empresas que aumentaram a sua diversificação geográfica e de produtos, atribuiu-se a estratégia de crescimento Diversificação.

Para as empresas que aumentaram a sua diversificação geográfica somente, atribuiu-se a estratégia de crescimento Expansão Geográfica.

Para as empresas que aumentaram a sua diversificação de produtos somente, atribuiuse a estratégia de crescimento Expansão de Produtos.

Para as empresas que não sofreram alterações significativas nos índices de diversificação (menos de 5\%), atribuiu-se a estratégia de crescimento Penetração de Mercado.

Em seguida, as empresas foram classificadas segundo o modelo de negócio predominante utilizado para atendimento das estratégias de crescimento. Para tanto, determinou-se o modelo de negócio que agregou maior participação em VGV relativamente ao portfólio de empreendimentos destinados aos novos segmentos e mercados (regiões geográficas), determinado pelo Índice de concentração por Modelo (ICM), representado pela equação 6. O fluxograma da figura abaixo apresenta o processo. 
Os modelos de negócios foram identificados por meio de pesquisa documental nos sítios de relacionamento com investidores. Foram identificadas as parcerias, joint ventures e aquisições publicadas nos fatos relevantes e comunicados ao mercado.

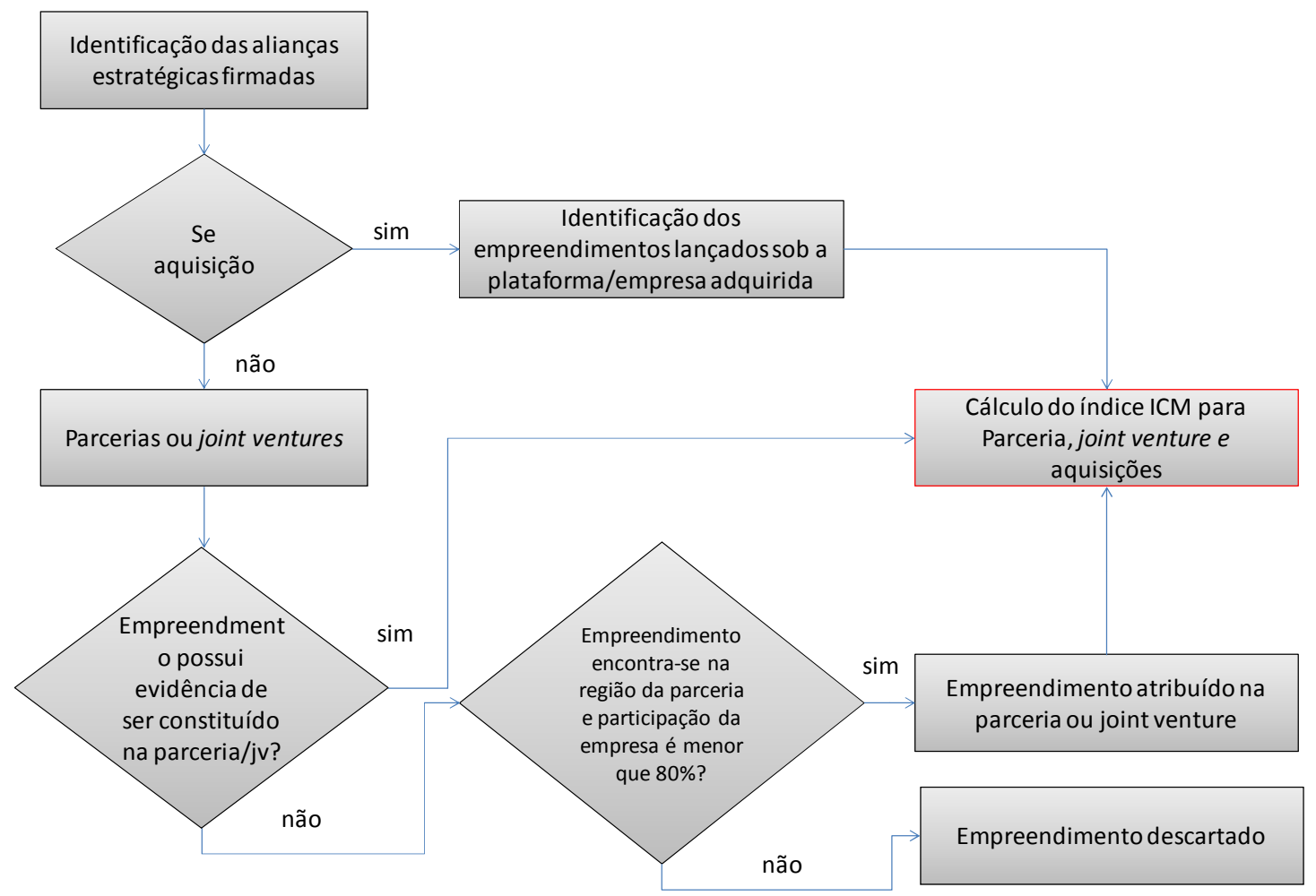

Figura 11 - Processo para cálculo do índice de concentração por modelo de negócio Fonte: Elaboração do autor

São consideradas evidências de participação dos empreendimentos nas parcerias ou joint ventures qualquer informação presente em notícia, comunicado, fato relevante, ficha técnica ou propaganda do empreendimento que indique a co-incorporação.

$I C M_{j, a}=\frac{\sum_{a=1}^{n} V G V_{a}}{V G V}$

, para a empresa $j$ e modelo de negócio tipo $a$ [parceria, joint venture, aquisição ou incorporação própria].

É importante destacar que as alianças estratégicas identificadas referem-se apenas àquelas cujo objetivo é a incorporação de empreendimentos. Alianças comerciais voltadas para a venda e financiamento de produtos e/ou da produção, ou outros tipos, 
não fazem parte do escopo do presente trabalho. Também não foram registradas as coincorporações em empreendimentos que não tiveram um prévio acordo, termo de compromisso, ou intenção de parceria registrados e comunicados entre as partes.

\subsection{Empresa protótipo}

Com o objetivo de exemplificar o uso dos indicadores de diversificação, são apresentadas abaixo empresas protótipo, $[\mathrm{A}],[\mathrm{B}]$... [E], de portfólios arbitrados em posições extremas e intermediárias de diversificação, tanto geográfica como por produtos.

A empresa [A] é protótipo de uma empresa de concentração de produtos e de território. É composta por empreendimentos imobiliários residenciais, todos destinados a um único segmento de renda localizados em um único território.

A empresa [B] é exemplo de concentração de produtos e diversificação territorial, enquanto a [C] apresenta concentração territorial e dominância de produto, e a empresa [D] diversificação de produtos.

A Tabela abaixo apresenta os índices de diversificação geográfica e de produtos para cada empresa protótipo.

Verifica-se que, dado os critérios para classificação de concentração e diversificação geográfica (item 6.1), uma empresa pode ser considerada diversificada territorialmente a partir do momento que empreende, aproximadamente, para cinco ou mais territórios igualmente distribuídos em termos de volume estimado de venda dos empreendimentos. Assim, a atribuição da empresa ser de concentração municipal, regional, estadual ou nacional, cabe às classificações de cada índice por unidade territorial, conforme explicado no item anterior.

Quanto à diversificação por produtos, uma empresa é considerada diversificada quando o índice de diversificação de produtos for superior a 0,71 , aproximadamente cinco sextos da escala, o que corresponde a aproximadamente possuir quatro ou mais segmentos de renda igualmente distribuídos no portfólio de empreendimentos. A de 
dominância de produtos é definida aproximadamente a empreender até três segmentos de renda, igualmente distribuídos em termos de volume estimado de vendas. Do contrário, a empresa é considerada de concentração de produtos.

Tabela 2 -Indicadores de diversificação para as empresas protótipo.

\begin{tabular}{|l|c|c|c|c|}
\hline \multicolumn{1}{|c|}{ Empresa } & [A] & [B] & [C] & [D] \\
\hline \multicolumn{1}{|c|}{ Classificação } & $\begin{array}{c}\text { Concentração de } \\
\text { Produtos e } \\
\text { concentração de } \\
\text { território }\end{array}$ & $\begin{array}{c}\text { Concentração de } \\
\text { produtos } \\
\text { diversificação de } \\
\text { territórios }\end{array}$ & $\begin{array}{c}\text { Dominância de } \\
\text { produtos e } \\
\text { concentração } \\
\text { de território }\end{array}$ & $\begin{array}{c}\text { Diversificação } \\
\text { de produtos e } \\
\text { concentração } \\
\text { de território }\end{array}$ \\
\hline Número de mercados & 1 & 5 & 1 & 1 \\
\hline Índice de diversificação geográfica [território] & 0,00 & 0,80 & 0,00 & 0,00 \\
\hline Número de produtos & 1 & 1 & 3 & 4 \\
\hline Índice de diversificação de produtos & 0,0 & 0,0 & 0,67 & 0,75 \\
\hline
\end{tabular}

Fonte: elaboração do autor

Conforme explicado no início do capítulo, a rotina apresentada será aplicada para as vinte e uma empresas objeto de investigação pelo autor, e seus resultados apresentados no capítulo oito. 


\subsection{Critérios e indicadores para a avaliação do desempenho do conjunto do mercado e das empresas de Real Estate}

Para análise do desempenho das empresas, a presente pesquisa buscou indicadores com o objetivo de analisar a capacidade da organização em gerar resultados e a eficácia na remuneração do capital do acionista. Para tanto, fez uso das demonstrações de resultados e balanços contábeis disponíveis para consulta na BM\&FBovespa.

É importante destacar que o trabalho analisa os indicadores com base em números contábeis, provenientes de balanços financeiros, e não de mercado de ações. O motivo é propiciar o entendimento apenas da capacidade da empresa em gerar resultado e remunerar o capital do acionista para um período pretérito. Se fossem empregados números de mercado, os resultados estariam sob o viés da percepção do valor da organização pelos investidores, o que foge do escopo do presente trabalho.

Assim, com o objetivo de analisar a eficácia da empresa na gestão de seus recursos, empregou-se o indicador lucro sobre o patrimônio líquido (LSPL) conforme equação 7. (MATARAZZO, 2010).

$$
L S P L_{i, t}=\left[\frac{\text { Lucro Líquido }_{i, t}}{\left(\frac{\left(P L_{i, t}+P L_{i, t-1}\right)}{2}\right)}\right]
$$

, para a empresa $i$ no período $t$, onde:

$P L=$ Patrimônio Líquido do último dia do exercício.

A capacidade da empresa em gerar resultado para o acionista, seja este distribuído ou não, foi avaliada por meio do indicador Margem Liquida (ML), conforme equação 08.

$$
M L_{i, t}=\frac{L L_{i, t}}{R V_{i, t}}
$$

, onde; 


$$
\begin{aligned}
& \mathrm{LL}=\text { Lucro líquido } \\
& \mathrm{RV}=\text { Receita de vendas }
\end{aligned}
$$

Em seguida, o indicador de ML de cada companhia, ou das amostras produzidas, foram comparados com a média do conjunto de empresas no período 2006 a 2010.

$u(M L)_{2006-2010}=\left[\frac{\sum_{i}^{n} \text { Lucro Líquido }_{i, 2006-2010}}{\sum_{i}^{n} \text { Receita de Vend } a_{i, 2006-2010}}\right]$

O próximo capítulo trata de aplicar a rotina explicado nos capítulos seis e sete nas empresas selecionadas. 


\section{RESULTADOS}

O presente capítulo tem como objetivo apresentar os resultados das classificações atribuídas às empresas, e compará-las com os indicadores de desempenho. Para tanto, foram constituídos mapas e gráficos com o objetivo de apresentar visualmente a importância de cada região geográfica e de segmento de renda no portfólio de lançamento de cada empresa, em valor estimado de venda, bem como um painel com um resumo de todas a evolução dos indicadores de desempenho e índices de diversificação durante o período de análise.

A relação das alianças estratégicas identificadas, a exposição do portfólio por modelo de negócio, o volume de lançamentos, bem como outras informações relacionadas às empresas que o autor julgou importantes, podem ser consultadas nos apêndices da presente dissertação.

\subsection{EMPRESAS}

\subsubsection{CCDI}

A Camargo Corrêa Desenvolvimento Imobiliário S.A (CCDI) foi fundada em 1996 com o objetivo de gerir os ativos imobiliários do grupo Camargo Corrêa. A partir do início da década de 2000, o grupo passou a utilizá-la como plataforma de investimento em empreendimentos imobiliários residenciais e comerciais na cidade de São Paulo, estruturando-a para as atividades de desenvolvimento, incorporação, construção e comercialização de empreendimentos. (CCDI, 2007)

Conforme índices e informações apresentadas na Tabela 3, no período 2005 a 2010 a CCDI saiu de uma posição de elevada exposição ao mercado da cidade de São Paulo e ao segmento de alta renda, para uma empresa com um portfólio de produtos diversificado, com maior exposição ao segmento econômico e atuação concentrada no estado de São Paulo.

Para a entrada no segmento econômico e expansão geográfica para os municípios do interior do estado de São Paulo, a empresa optou pelo modelo de negócio de aquisição, ao adquirir gradativamente participação na empresa HM Engenharia e Participações. 
Para a entrada em novos estados, a empresa optou pela realização de parcerias com empresas de conhecimento local.

Entre 2002 a 2005 a empresa focou suas atividades no município de São Paulo e nos segmento residencial de alto padrão.

Em 2006 a empresa iniciou seu processo de diversificação ao desenvolver empreendimento comercial no mercado da cidade do Rio de Janeiro, em sociedade com a Tishman Speyer, parceiro com tradição no segmento de lajes corporativas.

No ano de 2007, a empresa intensificou sua estratégia de expansão geográfica e de produtos. Para atendimento da primeira, firmou parceria com a empresa Lix da Cunha, com o objetivo de promover empreendimentos no município de Campinas e região lindeira. Como estratégia de entrada no segmento econômico e popular, adquiriu o controle da empresa HM Engenharia e Participações, cuja presença de escritórios nas regiões de Barretos e Campinas também facilitou o processo de expansão geográfica. Como resultado, em 2007 a empresa lançou no mercado produtos para diferentes segmentos de renda, no entanto, sua exposição permaneceu majoritariamente no segmento de média-alta renda. Quanto à sua atuação geográfica, apesar dos lançamentos realizados no estado do Rio de Janeiro, a empresa ainda possuía elevada concentração no estado de São Paulo.

O ano de 2008 consolidou a estratégia da empresa no segmento econômico, passando a representar $73 \%$ do portfólio de lançamentos da empresa, em volume esperado de vendas. A empresa passou a deter $100 \%$ do capital social da HM, e elevou a participação dos segmentos de menor poder aquisitivo em relação aos segmentos de média-alta e alta renda.

No ano de 2009 a empresa ampliou sua expansão geográfica ao realizar lançamento no mercado da cidade de Curitiba. A empresa fez uso de competências e recursos próprios para a formatação e desenvolvimento do projeto, no entanto, firmou parceria com empresa local para a atividade de construção. 
No ano de 2010, com o objetivo de dar continuidade ao crescimento almejado, a empresa firmou acordos operacionais com três empresas: com a incorporadora Kallas, o objetivo de agregar maior volume de empreendimentos na cidade de São Paulo e litoral do estado; com a JL construções o desenvolvimento de empreendimentos na cidade de Curitiba; e com a InterRio a entrada no estado do Rio de Janeiro, ocorrida por meio de empreendimento na cidade de Macaé.

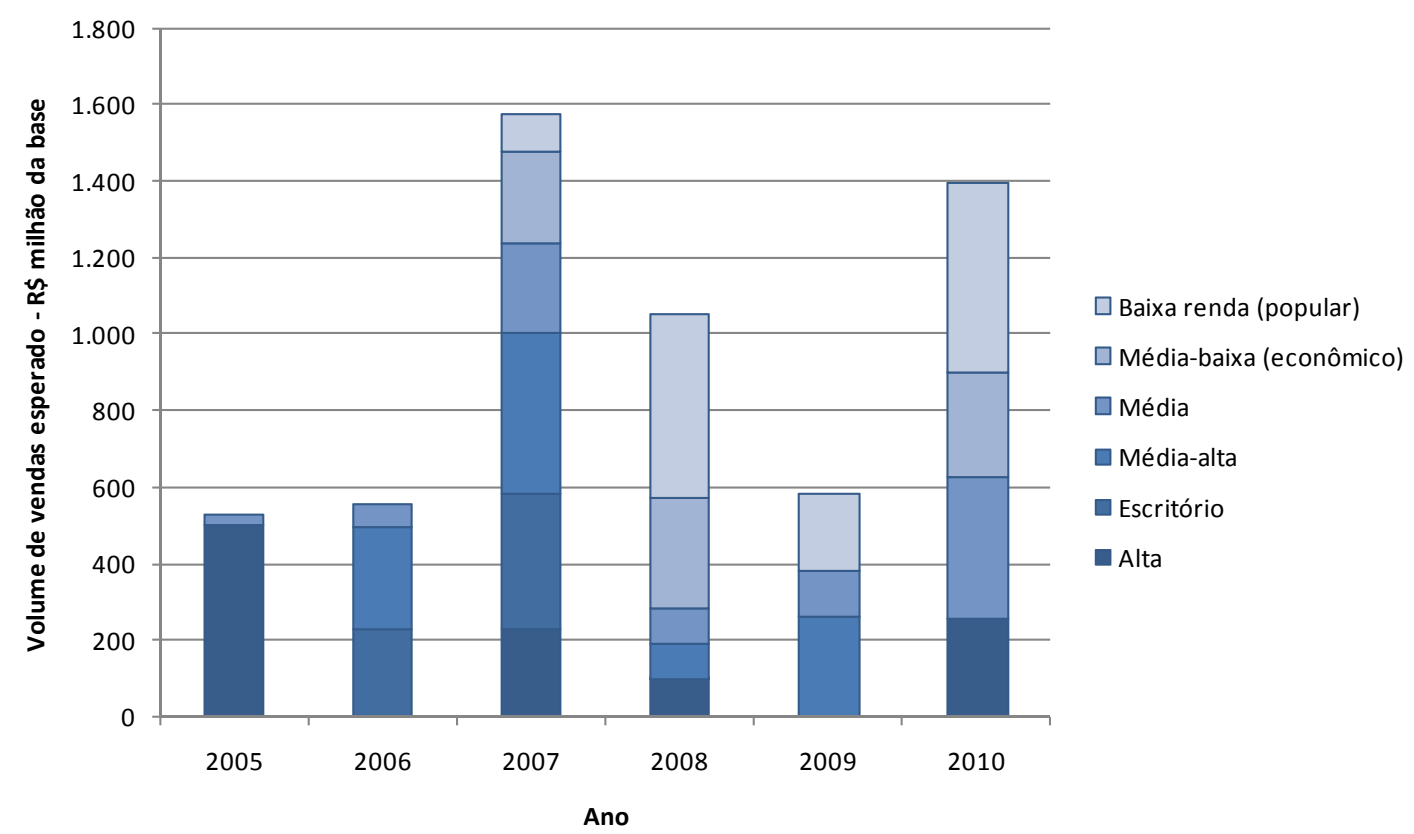

Gráfico 6 - Lançamentos por segmento de renda - CCDI- em volume estimado de venda em R\$ milhão da base

Fonte: Elaboração do autor 
Volume estimado de venda - $\mathrm{R} \$$ milhão da base

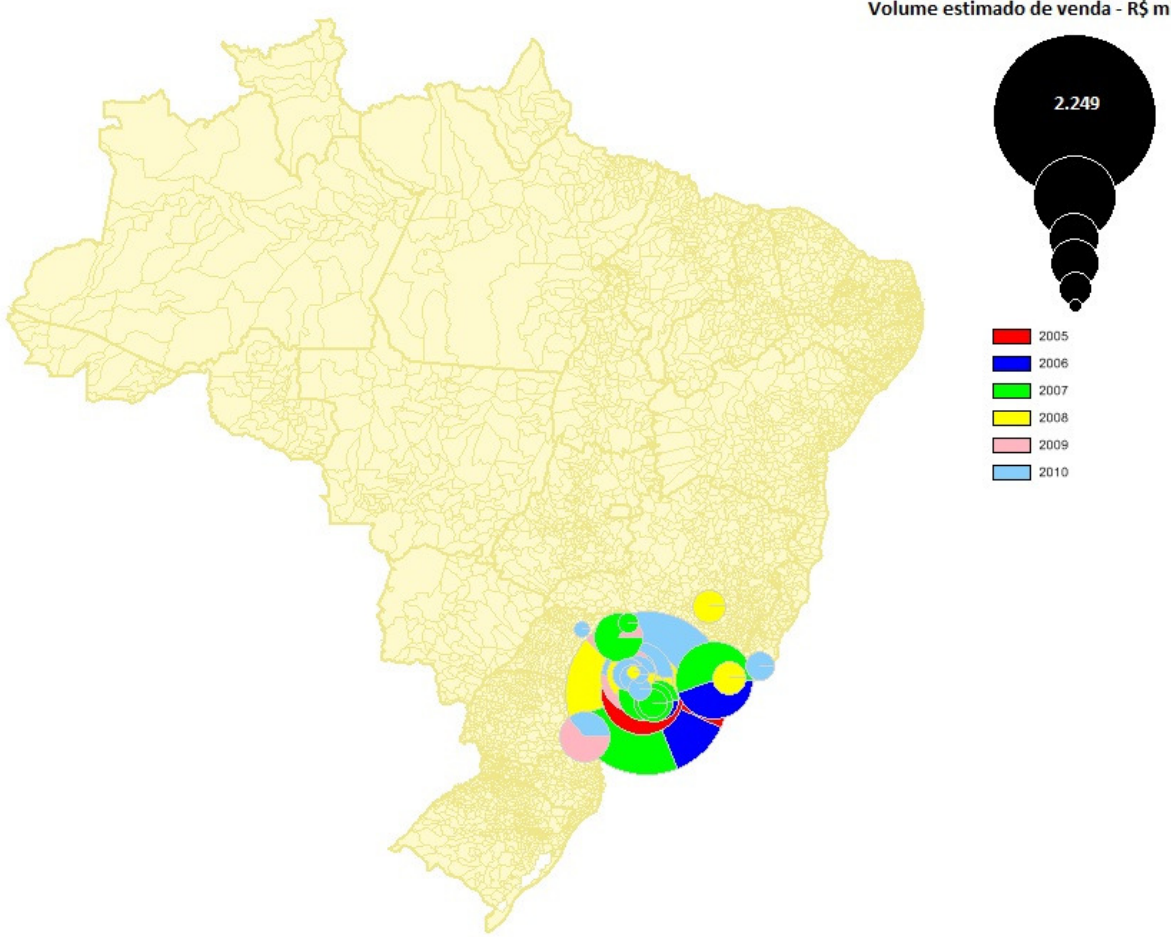

Figura 12 - Mapa de lançamentos da empresa CCDI

Fonte: Elaboração do autor 
Tabela 3 - Painel de Indicadores da Empresa CCDI

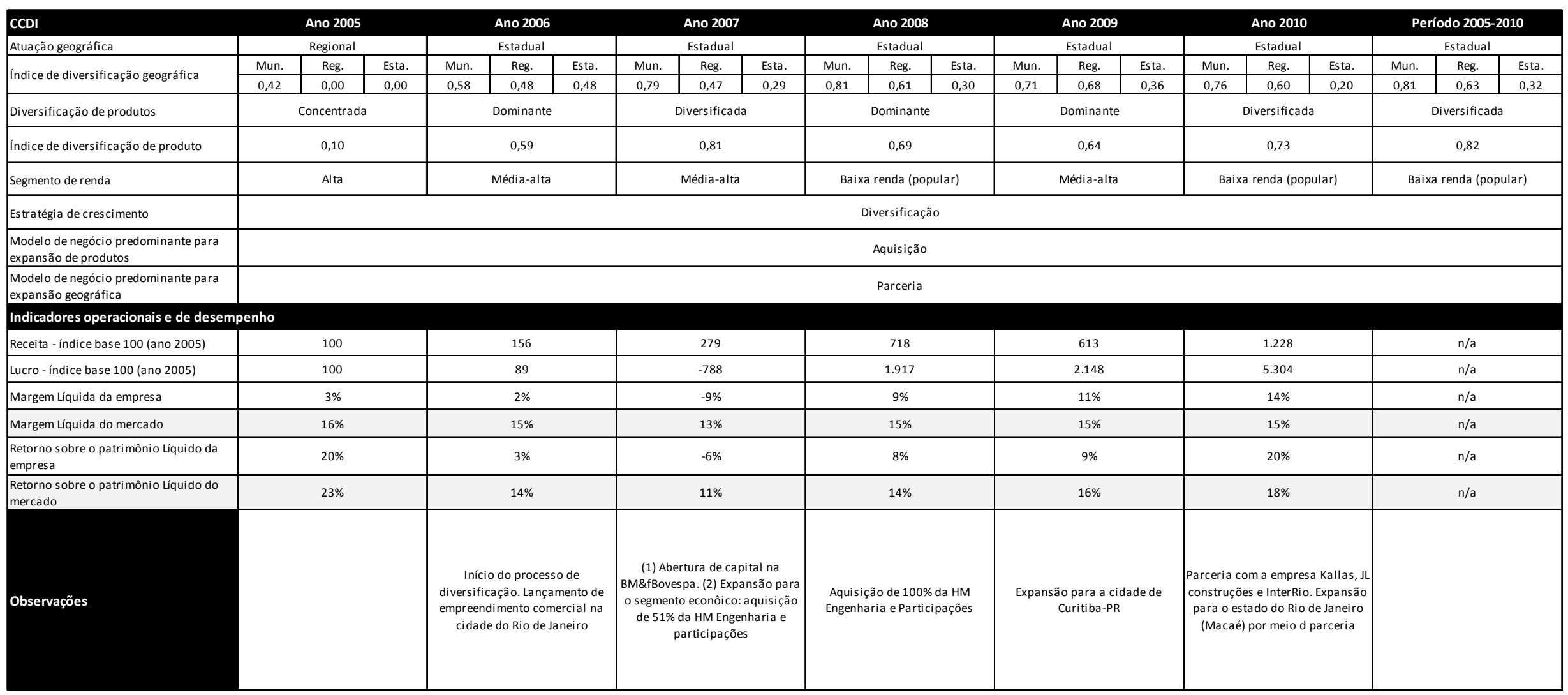

Fonte: Elaboração do autor 


\subsubsection{CYRELA}

A Cyrela Brazil Realty é uma das maiores e mais tradicionais empresas do setor da construção civil brasileira, sendo a empresa com maior volume de lançamentos no período 2005-2010 em valor geral de venda dos empreendimentos, segundo dados levantados pelo próprio autor.

Conforme índices e informações apresentadas no Tabela 4, no período 2005 a 2010 a Cyrela saiu de uma empresa de concentração estadual e diversificação dominante de produtos, com maior exposição no segmento de média-alta renda, para uma empresa de atuação nacional e portfólio diversificado de produtos.

Como estratégia de expansão de produtos, a empresa fez uso gradual de parcerias e joint ventures, de maneira a propiciar o desenvolvimento da plataforma Living, construtora própria especializada na produção de unidades destinadas aos segmentos econômico e popular. As parcerias tiveram como objetivo realizar os primeiros projetos destinados ao publico de menor poder aquisitivo, através da co-incorporação pontual em nível das sociedades de propósito específico dos empreendimentos. Entre as parcerias realizadas, destacam-se as iniciadas em 2006 com as empresas Plano e Plano, Goldfarb e Concima.

Posteriormente, a parceria realizada com a Plano e Plano foi transformada numa joint venture de participação igualitária entre as organizações, cujo modelo permanece até a data da presente dissertação.

A empresa Goldfarb, atualmente pertencente à empresa concorrente PDG, conforme será detalhado em capítulo posterior, permanece como uma empresa parceira com a realização pontual de empreendimentos.

A empresa Concima foi adquirida pela Cyrela no ano de 2008, e seus recursos absorvidos pela construtora Living. 
Em 2007 foram realizadas joint ventures com as empresas Cury e Tecnum, cuja aliança permanece até a data da presente dissertação e fazem parte do modelo de desenvolvimento de produtos para os segmentos popular e econômico.

Como estratégia de expansão geográfica, a Cyrela fez uso de diversos modelos de negócios. Para os estados de Santa Catarina e região Centro-Oeste, Norte e Nordeste do país, a Cyrela firmou parcerias com as empresas Cota empreendimentos imobiliários, Santa Izabel, MAC, Marquise, Incortel, Agra, EBM construtora, Doria construtora e outras. Por meio das joint ventures com as construtoras Lider e Andrade Mendonça, a Cyrela entrou nos mercados, respectivamente, de Minas Gerais, Distrito Federal e Bahia.

Como estratégia de entrada no mercado da região Sul e expansão para o segmento econômico, a empresa adquiriu o controle da empresa Goldsztein, antes uma joint venture entre as companhias.

Segundo informações disponíveis no prospecto de emissão primária de ações (CYRELA, 2006), a empresa considera as parcerias um meio de fazer uso das competências de mercado, de produtos e da marca do parceiro, que, aliado à escala e ao conhecimento financeiro da Cyrela, permite a entrada em novos segmentos e mercados de maneira eficiente. 


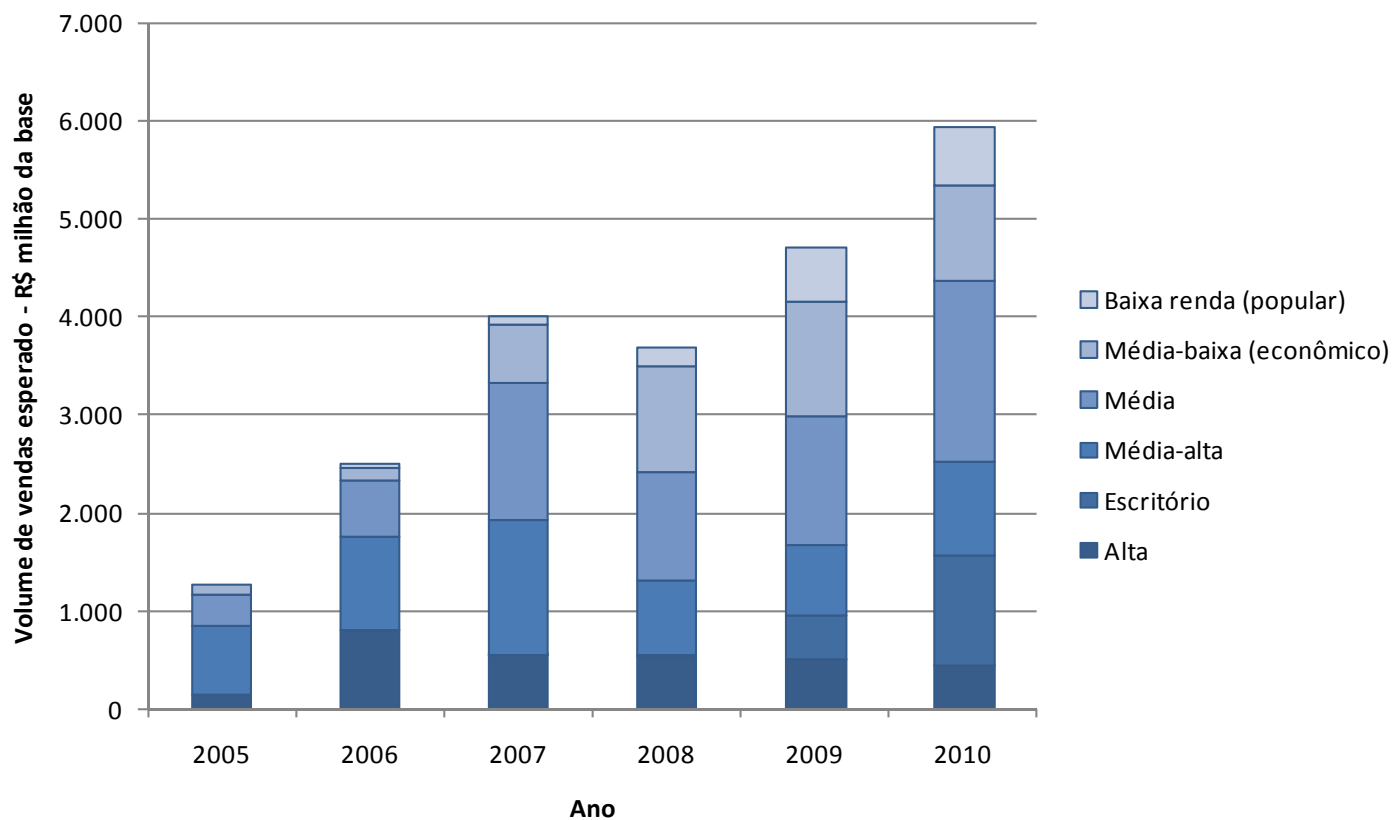

Gráfico 7 - Lançamentos por segmento de renda - Cyrela- em volume estimado de venda em R\$ milhão da base.

Fonte: elaboração do autor

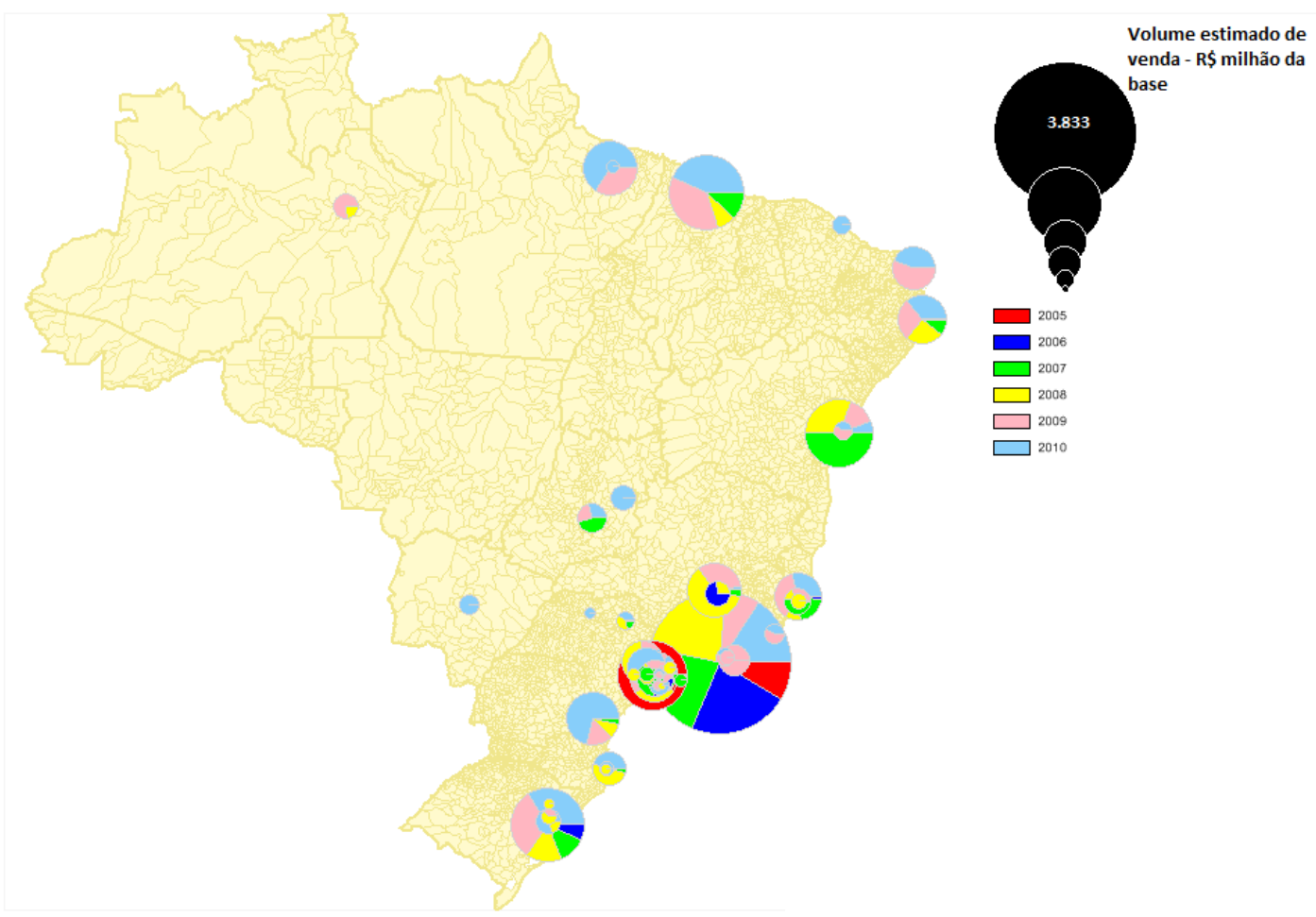

Figura 13 - Mapa de lançamentos da empresa Cyrela.

Fonte: Elaboração do autor 
Tabela 4 - Painel de Indicadores da empresa Cyrela

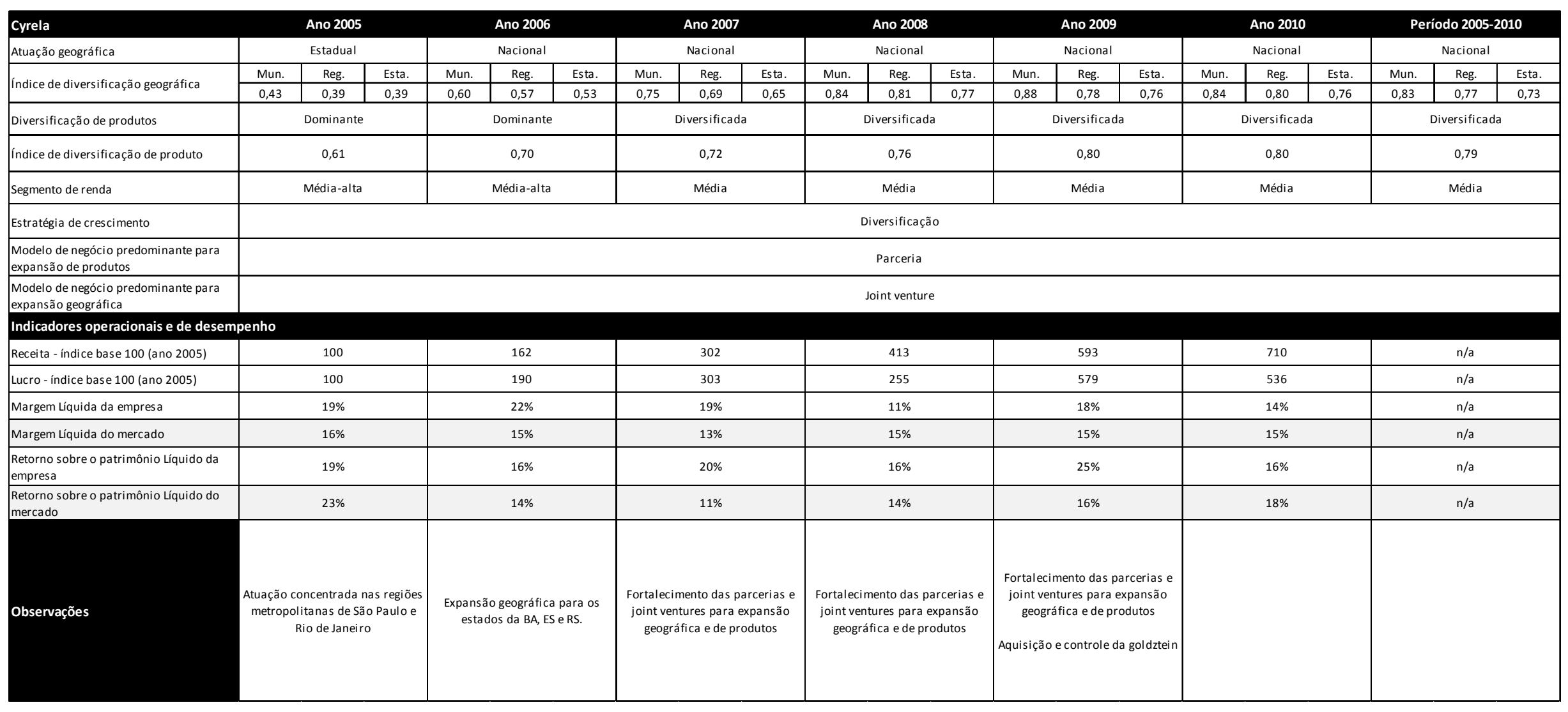

Fonte: Elaboração do autor 


\subsubsection{COMPANY, BRASCAN E BROOKFIELD}

A empresa Brookfield é resultado da fusão entre as empresas Brascan e Company e, posteriormente, da aquisição da empresa MB Engenharia. O grupo fez uso de aquisições para crescer e expandir seus negócios para outros mercados.

Entre 2005 e 2007, as empresas Company e Brascan eram relativamente equivalentes em termos de geração de receita, volume de empreendimentos e concentrações de mercados e produtos. Enquanto a primeira possuía elevada exposição na cidade de São Paulo e nos segmentos de média e alta renda, a Brascan, além da exposição ao mercado de alta renda, possuía significativa concentração nos mercados das cidades do Rio de Janeiro e São Paulo.

Ambas as empresas abriram capital na BM\&Fbovespa em 2006, e possuíam como estratégia declarada a diversificação de produtos e mercados.

Em 2007, a Company iniciou sua estratégia de expansão geográfica ao realizar poucos lançamentos em cidades do interior do estado de São Paulo e da região metropolitana da capital, passando de uma atuação municipal para regional. Simultaneamente, ampliou o seu portfólio de produtos ao realizar lançamentos para os segmentos econômico e escritórios, ambos por meio de incorporação própria.

Em 2008, as empresas Brascan e Company fundiram suas operações. Meses depois, com o objetivo de expandir a atuação da organização para outros mercados do país, o grupo adquiriu o controle da $\mathrm{MB}$ engenharia, empresa com atuação na região do centro-oeste brasileiro.

Em 2009, o grupo optou por reunir na marca Brookfield Incorporações todas as suas marcas existentes, com o objetivo de reforçar a operação sob uma plataforma única e integrada.

Para a entrada nos segmentos popular e econômico, a Brookfield optou pelo modelo de incorporação própria, ao desenvolver competências de engenharia e produtos por meio de recursos internos a companhia. 


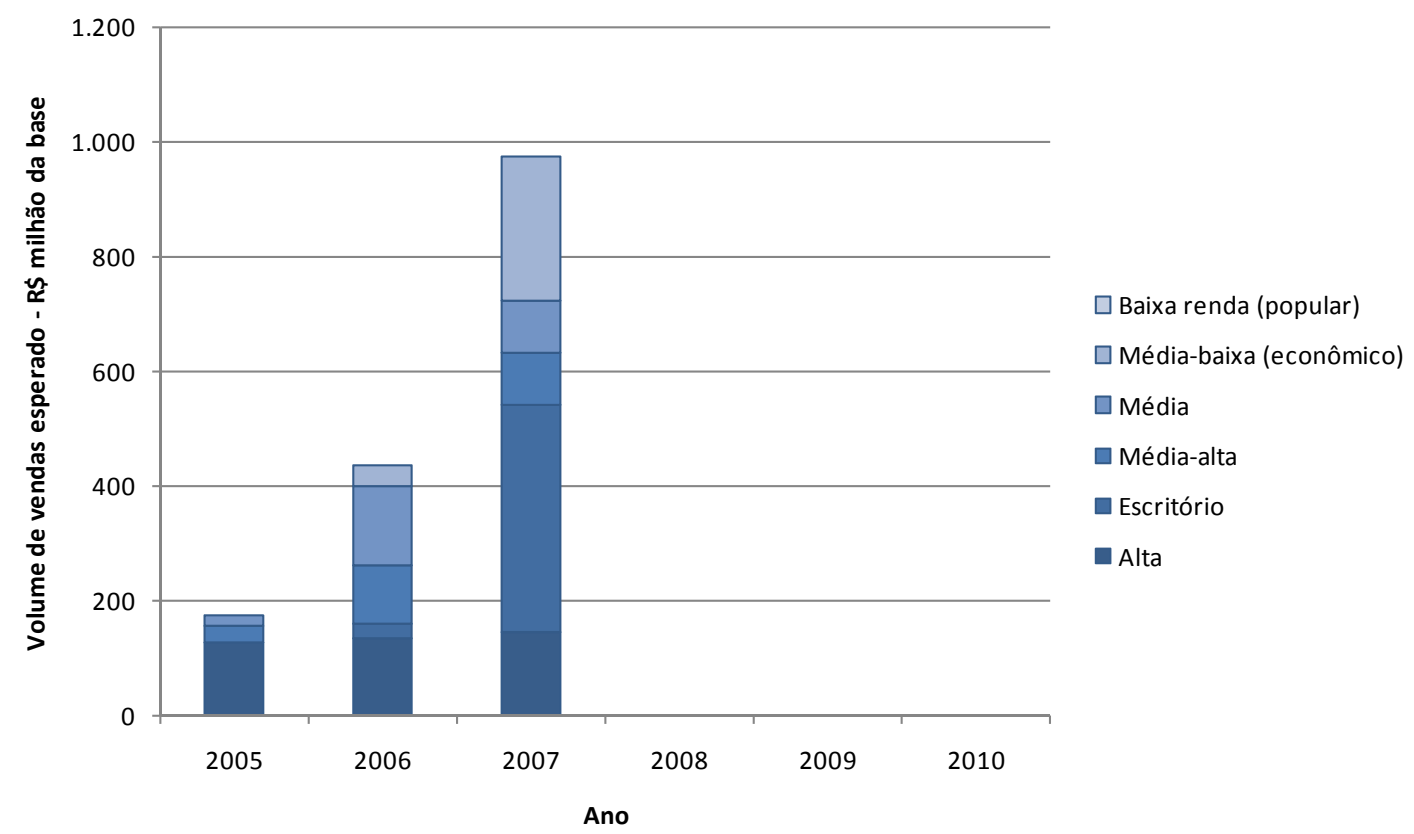

Gráfico 8 - Lançamentos por segmento de renda - Company - em volume estimado de venda em R \$ milhão da base.

Fonte: Elaboração do autor

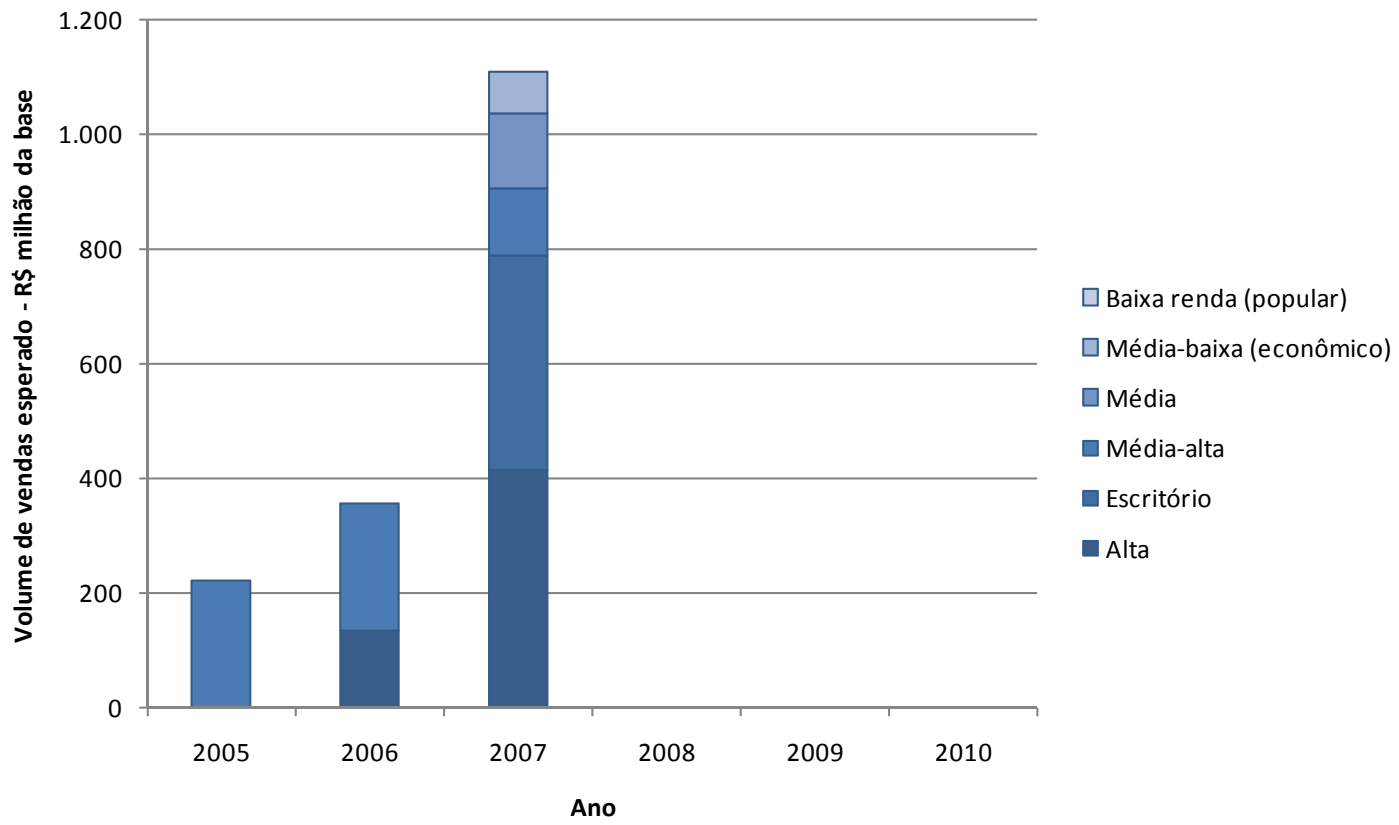

Gráfico 9 - Lançamentos por segmento de renda - Brascan - em volume estimado de venda em R \$ milhão da base.

Fonte: Elaboração do autor 


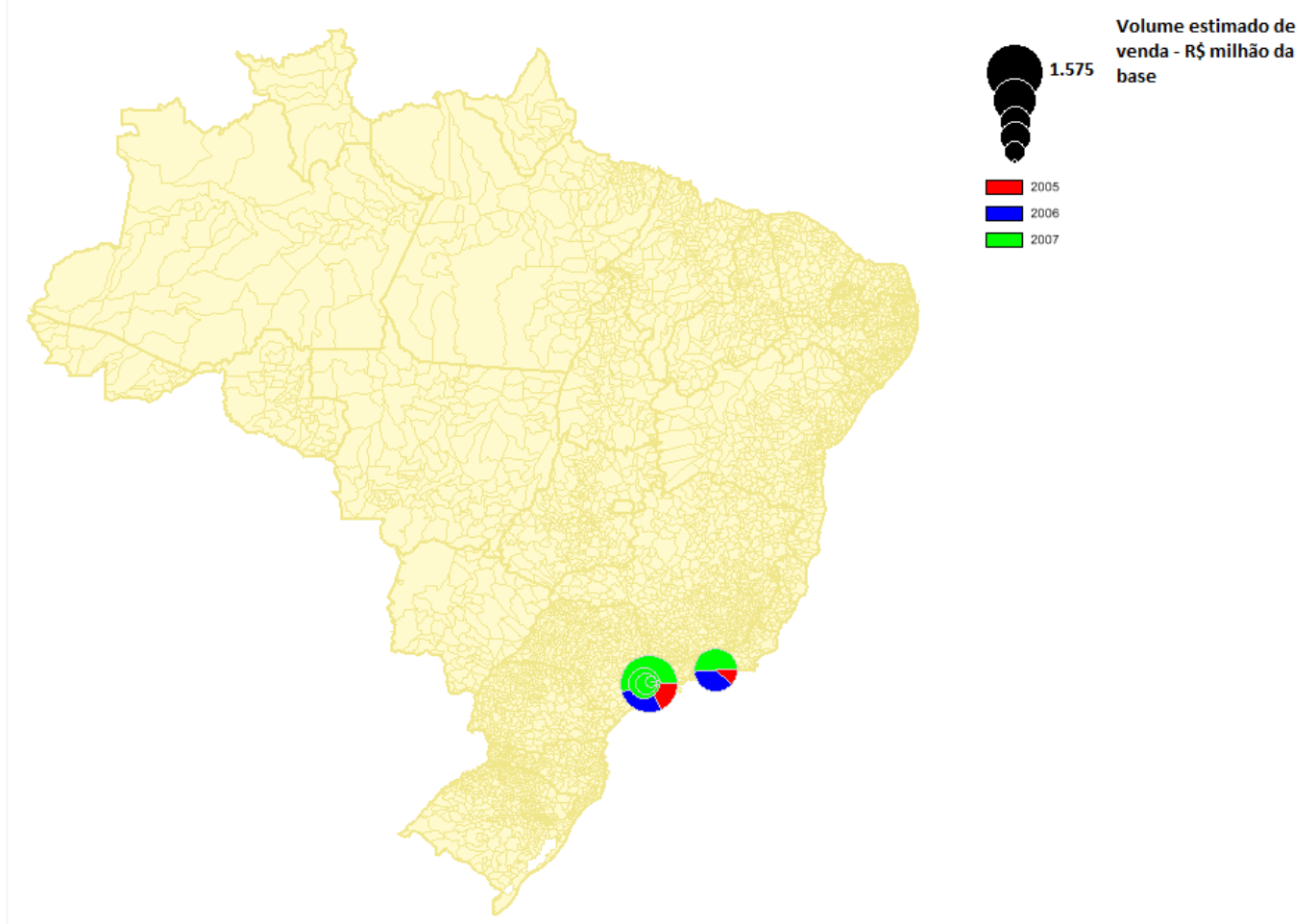

Figura 14 - Mapa de lançamentos das empresas Brascan e Company. Fonte: Elaboração do autor

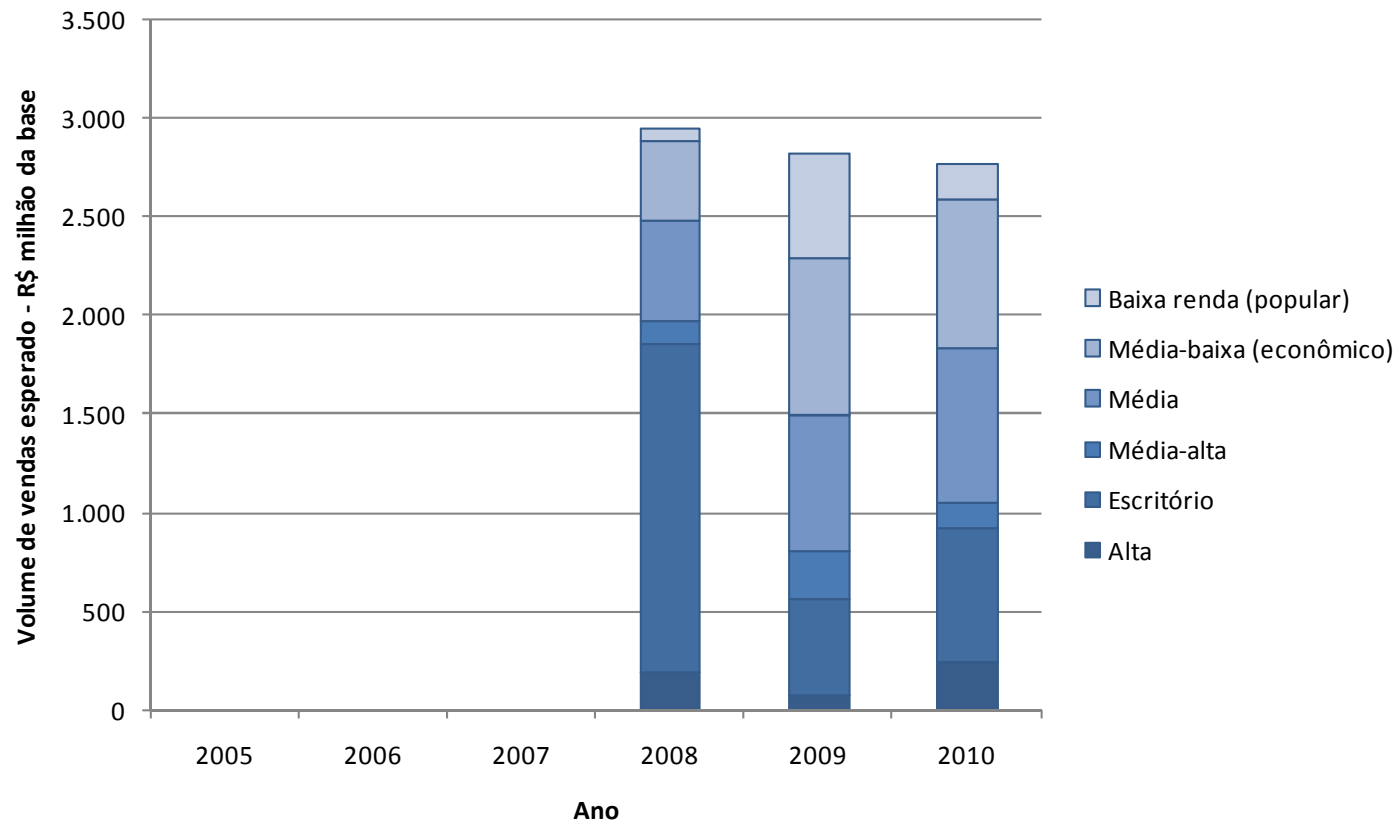

Gráfico 10 - Lançamentos por segmento de renda-Brookfield- em volume estimado de venda em R\$ milhão da base.

Fonte: Elaboração do autor 


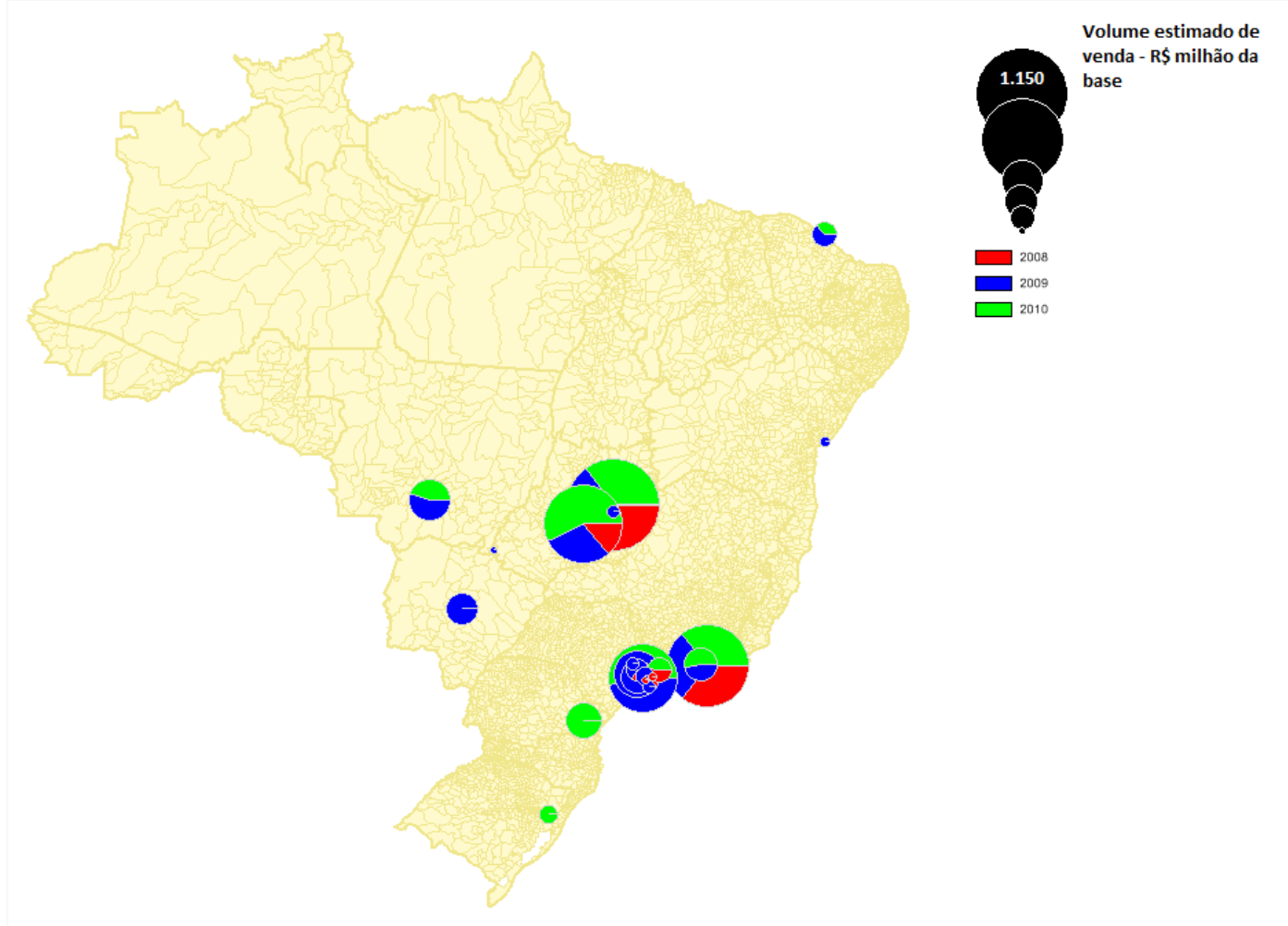

Figura 15 - Mapa de lançamentos da Empresa Brookfield.

Fonte: Elaboração do autor 
Tabela 5 - Painel de Indicadores da Empresa Company

\begin{tabular}{|c|c|c|c|c|c|c|c|c|c|c|c|c|c|c|c|c|c|c|c|c|c|}
\hline \multirow{4}{*}{\begin{tabular}{|l|} 
Company \\
Atuação geográfica \\
Índice de diversificação geográfica \\
\end{tabular}} & \multicolumn{3}{|c|}{ Ano 2005} & \multicolumn{3}{|c|}{ Ano 2006} & \multicolumn{3}{|c|}{ Ano 2007} & \multicolumn{3}{|c|}{ Ano 2008} & \multicolumn{3}{|c|}{ Ano 2009} & \multicolumn{3}{|c|}{ Ano 2010} & \multicolumn{3}{|c|}{ Período 2005-2007 } \\
\hline & \multicolumn{3}{|c|}{ Municipal } & \multicolumn{3}{|c|}{ Municipal } & \multirow{2}{*}{\multicolumn{3}{|c|}{$\frac{\text { Regional }}{\text { Reg }}$}} & \multirow{2}{*}{\multicolumn{3}{|c|}{$\mathrm{n} / \mathrm{a}$}} & \multirow{2}{*}{\multicolumn{3}{|c|}{$\begin{array}{l}\mathrm{n} / \mathrm{a} \\
\mathrm{Reg} .\end{array}$}} & \multirow{2}{*}{\multicolumn{3}{|c|}{$\mathrm{n} / \mathrm{a}$}} & \multicolumn{3}{|c|}{ Regional } \\
\hline & Mun. & Reg. & Esta. & Mun. & Reg. & Esta. & Mun. & & Esta. & & & Esta. & & & & & & Esta. & Mun. & Reg. & Esta. \\
\hline & 0,00 & 0,00 & 0,00 & 0,00 & 0,00 & 0,00 & 0,55 & 0,00 & 0,00 & $\mathrm{n} / \mathrm{a}$ & $\mathrm{n} / \mathrm{a}$ & $\mathrm{n} / \mathrm{a}$ & $\mathrm{n} / \mathrm{a}$ & $\mathrm{n} / \mathrm{a}$ & $\mathrm{n} / \mathrm{a}$ & $\mathrm{n} / \mathrm{a}$ & $\mathrm{n} / \mathrm{a}$ & $\mathrm{n} / \mathrm{a}$ & 0,42 & 0,00 & 0,00 \\
\hline Diversificação de produtos & \multicolumn{3}{|c|}{ Concentrada } & \multicolumn{3}{|c|}{ Diversificada } & \multicolumn{3}{|c|}{ Diversificada } & \multicolumn{3}{|c|}{$\mathrm{n} / \mathrm{a}$} & \multicolumn{3}{|c|}{$n / a$} & \multicolumn{3}{|c|}{$n / a$} & \multicolumn{3}{|c|}{ Diversificada } \\
\hline Índice de diversificação de produto & \multicolumn{3}{|c|}{0,43} & \multicolumn{3}{|c|}{0,74} & \multicolumn{3}{|c|}{0,73} & \multicolumn{3}{|c|}{$\mathrm{n} / \mathrm{a}$} & \multicolumn{3}{|c|}{$n / a$} & \multicolumn{3}{|c|}{ n/a } & \multicolumn{3}{|c|}{0,78} \\
\hline Segmento de renda & & Alta & & & Média & & & Escritór & & & $\mathrm{n} / \mathrm{a}$ & & & $\mathrm{n} / \mathrm{a}$ & & & $n / a$ & & & Escritóri & \\
\hline Estratégia de crescimento & & & & & & & & & & & ersific & & & & & & & & & & \\
\hline $\begin{array}{l}\text { Modelo de negócio predominante para } \\
\text { expansão de produtos }\end{array}$ & & & & & & & & & & Dese & Ivimen & ́prio & & & & & & & & & \\
\hline $\begin{array}{l}\text { Modelo de negócio predominante para } \\
\text { expansão geográfica }\end{array}$ & & & & & & & & & & & $\mathrm{n} / \mathrm{a}$ & & & & & & & & & & \\
\hline Indicadores operacionais e de dese & enho & & & & & & & & & & & & & & & & & & & & \\
\hline Receita - índice base 100 (ano 2005) & & 100 & & & 185 & & & 285 & & & 0 & & & 0 & & & 0 & & & n/a & \\
\hline Lucro - índice base 100 (ano 2005) & & 100 & & & 436 & & & 529 & & & 0 & & & 0 & & & 0 & & & n/a & \\
\hline Margem Líquida da empresa & & $7 \%$ & & & $16 \%$ & & & $12 \%$ & & & $\mathrm{n} / \mathrm{a}$ & & & $\mathrm{n} / \mathrm{a}$ & & & $\mathrm{n} / \mathrm{a}$ & & & $n / a$ & \\
\hline Margem Líquida do mercado & & $16 \%$ & & & $15 \%$ & & & $13 \%$ & & & $15 \%$ & & & $15 \%$ & & & $15 \%$ & & & n/a & \\
\hline $\begin{array}{l}\text { Retorno sobre o patrimônio Líquido da } \\
\text { empresa }\end{array}$ & & $23 \%$ & & & $27 \%$ & & & $18 \%$ & & & $n / a$ & & & $\mathrm{n} / \mathrm{a}$ & & & $n / a$ & & & $n / a$ & \\
\hline $\begin{array}{l}\text { Retorno sobre o patrimônio Líquido do } \\
\text { mercado }\end{array}$ & & $23 \%$ & & & $14 \%$ & & & $11 \%$ & & & $14 \%$ & & & $16 \%$ & & & $18 \%$ & & & $n / a$ & \\
\hline Observações & $\begin{array}{r}\text { Atuação } \\
\text { metropoli } \\
\text { segm }\end{array}$ & $\begin{array}{l}\text { oncentr } \\
\text { ana de } \\
\text { nto de a }\end{array}$ & $\begin{array}{l}\text { na região } \\
\text { aulo e no } \\
\text { enda }\end{array}$ & $\begin{array}{l}\text { Lançamen } \\
\text { de escritó }\end{array}$ & $\begin{array}{l}\text { de emp } \\
\text { os e pa } \\
\text { econôm }\end{array}$ & $\begin{array}{l}\text { dimentos } \\
\text { egmento }\end{array}$ & $\begin{array}{l}\text { Lançamer } \\
\text { de escrit }\end{array}$ & $\begin{array}{l}\text { to de emp } \\
\text { rios e pa } \\
\text { econôm }\end{array}$ & $\begin{array}{l}\text { dimentos } \\
\text { egmento }\end{array}$ & & coma & & & & & & & & & & \\
\hline
\end{tabular}

Fonte: elaboração do autor 
Tabela 6 - Painel de Indicadores das empresas Brascan e Brookfield.

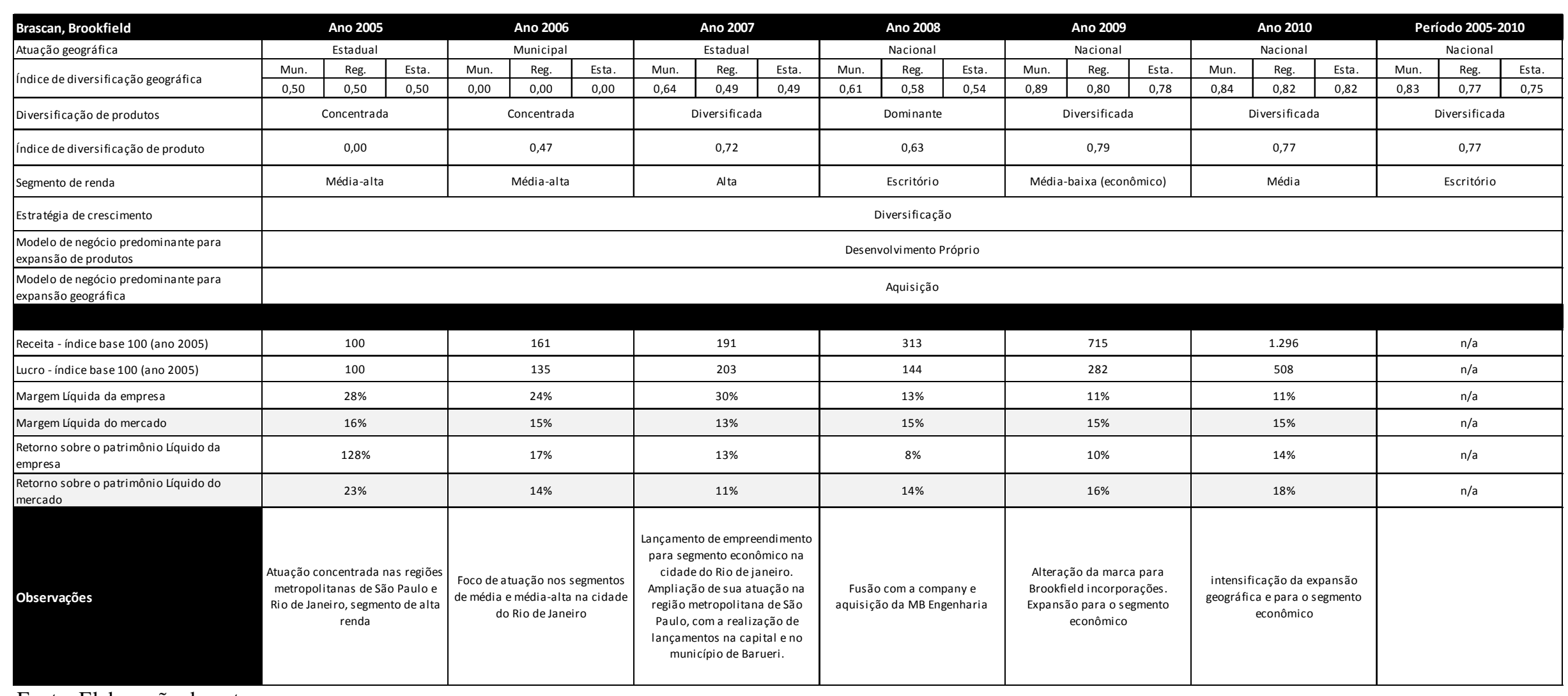

Fonte: Elaboração do autor 


\subsubsection{TRISUL}

A empresa Trisul abriu capital da BM\&FBovespa em 2007, e é o resultado na união entre as empresas Tricory e Incosul, duas tradicionais empresas da Região Metropolitana de são Paulo.

Conforme demonstrado pelos índices e informações presentes no quadro abaixo, a empresa apresentou em 2007 atuação concentrada na região metropolitana de São Paulo e no segmento de média-alta renda.

Ao longo do período 2007-2010, a empresa expandiu sua atuação para outros municípios do estado de São Paulo e realizou lançamentos destinados ao segmento econômico, sendo classificada, segundo os critérios adotados na presente dissertação, como uma empresa de estadual e portfólio diversificado de produtos.

Não foram identificados casos de alianças estratégicas com objetivo de expansão para novos mercados ou produtos. Neste caso, a empresa fez uso de desenvolvimento interno de competências.

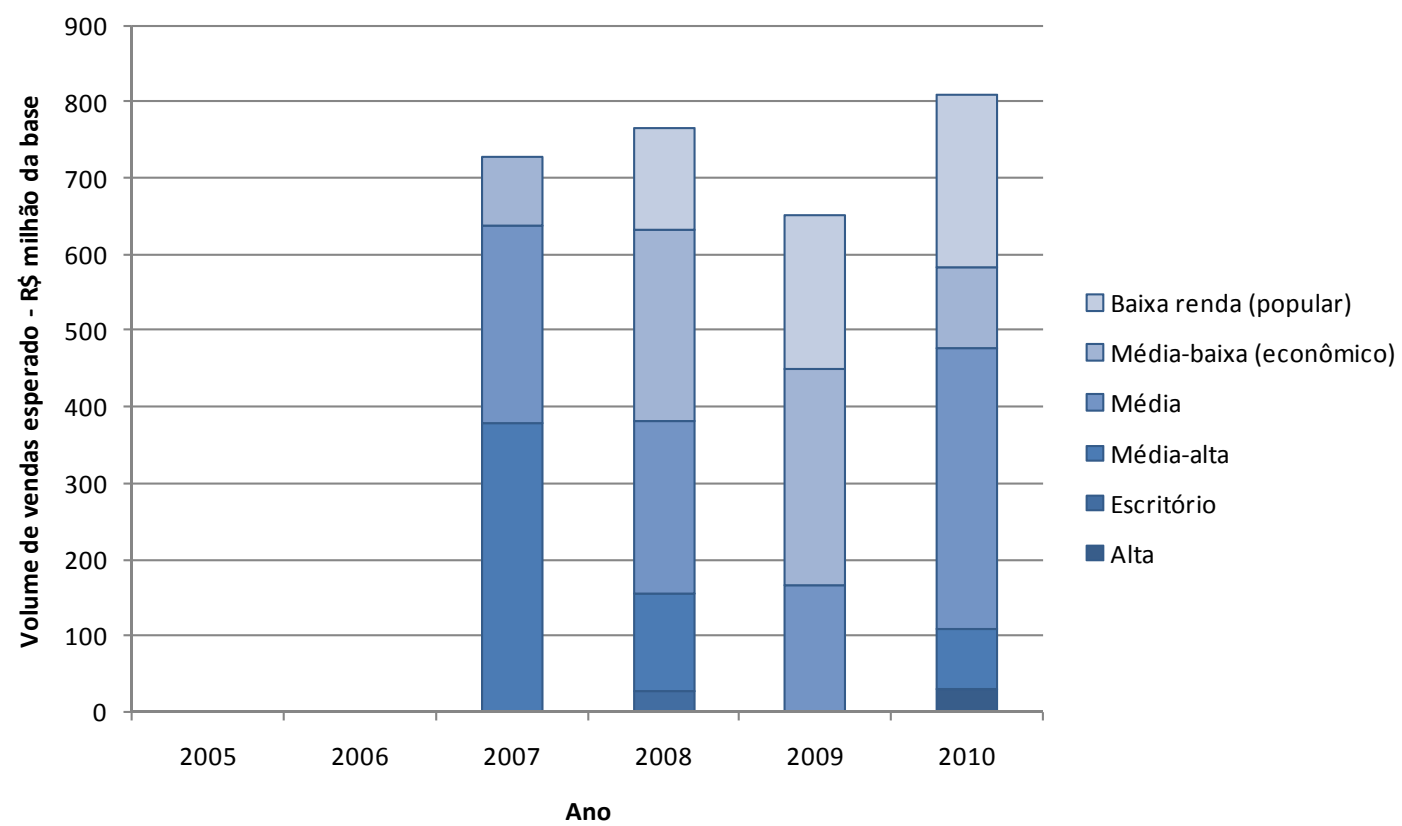

Gráfico 11 - Lançamentos por segmento de renda - Trisul - em volume estimado de venda em R \$ milhão da base.

Fonte: elaboração do autor 


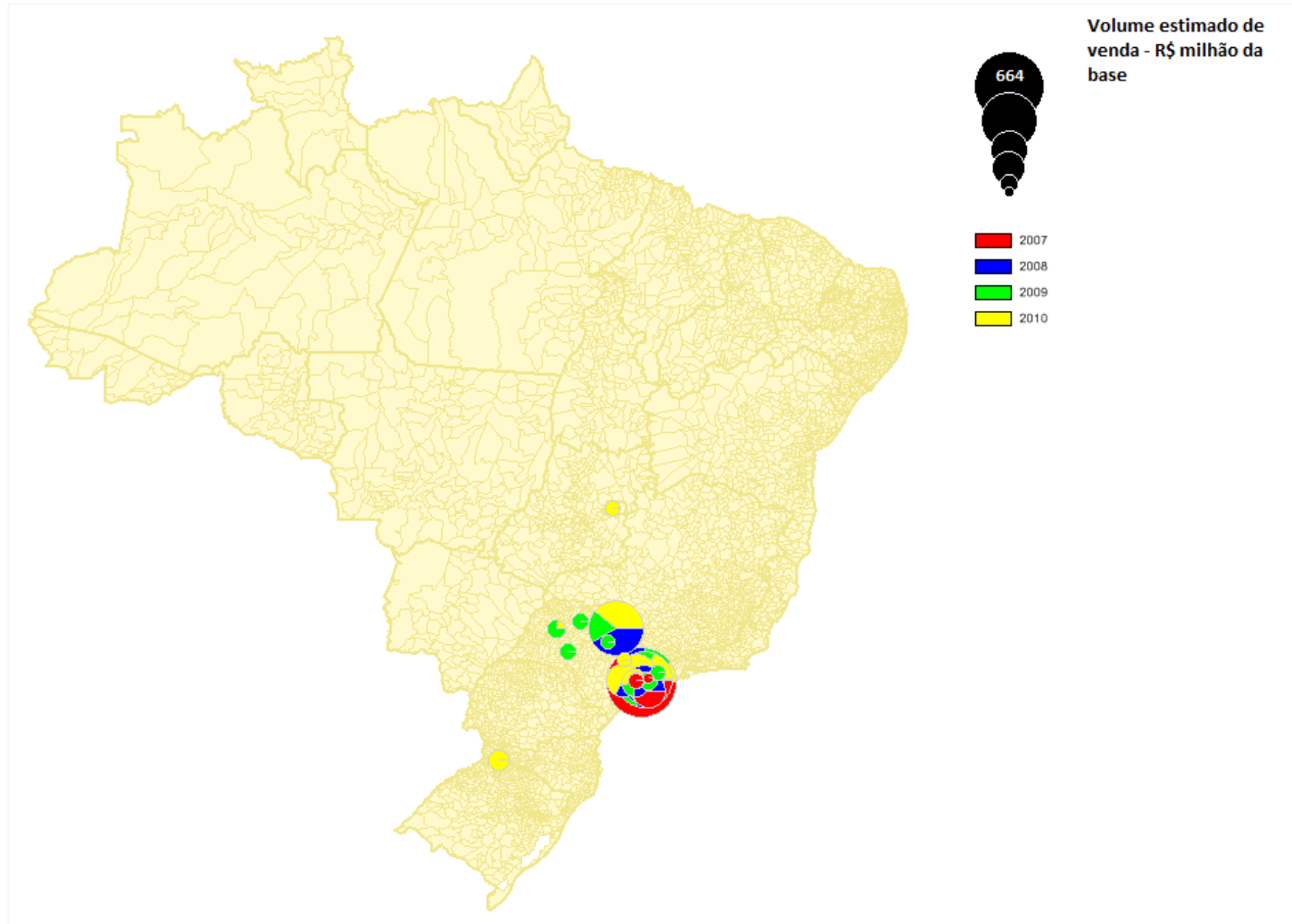

Figura 16 - Mapa de lançamentos da Empresa Trisul. Fonte: elaboração do autor 
Tabela 7 - Painel de Indicadores da empresa Trisul

\begin{tabular}{|c|c|c|c|c|c|c|c|c|c|c|c|c|c|c|c|c|c|c|c|c|c|}
\hline \multirow{4}{*}{\begin{tabular}{|l|} 
Trisul \\
Atuação geográfica \\
Índice de diversificação geográfica \\
\end{tabular}} & \multirow{2}{*}{\multicolumn{3}{|c|}{$\begin{array}{c}\text { Ano } 2005 \\
\text { n/a }\end{array}$}} & \multirow{2}{*}{\multicolumn{3}{|c|}{$\begin{array}{c}\text { Ano } 2006 \\
\text { Regional }\end{array}$}} & \multirow{2}{*}{\multicolumn{3}{|c|}{$\begin{array}{l}\text { Ano } 2007 \\
\text { Regional }\end{array}$}} & \multicolumn{3}{|c|}{ Ano 2008} & \multicolumn{3}{|c|}{ Ano 2009} & \multicolumn{3}{|c|}{ Ano 2010} & \multicolumn{3}{|c|}{ Período 2005-2010 } \\
\hline & & & & & & & & & & \multirow{2}{*}{\multicolumn{3}{|c|}{$\begin{array}{c}\frac{\text { Estadual }}{\text { Reg. }} \\
\text {. }\end{array}$}} & \multicolumn{3}{|c|}{ Estadual } & \multicolumn{3}{|c|}{ Estadual } & \multicolumn{3}{|c|}{ Estadual } \\
\hline & Mun. & Reg. & Esta. & Mun. & Reg. & Esta. & Mun. & Reg. & Esta. & & & & Mun. & Reg. & Esta. & Mun. & Reg. & Esta. & Mun. & Reg. & Esta. \\
\hline & $\mathrm{n} / \mathrm{a}$ & $\mathrm{n} / \mathrm{a}$ & $\mathrm{n} / \mathrm{a}$ & $\mathrm{n} / \mathrm{a}$ & $\mathrm{n} / \mathrm{a}$ & $\mathrm{n} / \mathrm{a}$ & 0,64 & 0,00 & 0,00 & 0,86 & 0,60 & 0,00 & 0,82 & 0,58 & 0,00 & 0,89 & 0,72 & 0,20 & 0,88 & 0,55 & 0,06 \\
\hline Diversificação de produtos & \multicolumn{3}{|c|}{ n/a } & \multicolumn{3}{|c|}{$n / a$} & \multicolumn{3}{|c|}{ Dominante } & \multicolumn{3}{|c|}{ Diversificada } & \multicolumn{3}{|c|}{ Dominante } & \multicolumn{3}{|c|}{ Dominante } & \multicolumn{3}{|c|}{ Diversificada } \\
\hline Índice de diversificação de produto & \multicolumn{3}{|c|}{$\mathrm{n} / \mathrm{a}$} & \multicolumn{3}{|c|}{$\mathrm{n} / \mathrm{a}$} & \multicolumn{3}{|c|}{0,59} & \multicolumn{3}{|c|}{0,75} & \multicolumn{3}{|c|}{0,65} & \multicolumn{3}{|c|}{0,69} & \multicolumn{3}{|c|}{0,74} \\
\hline Segmento de renda & \multicolumn{3}{|c|}{$n / a$} & \multicolumn{3}{|c|}{$n / a$} & \multicolumn{3}{|c|}{ Média-alta } & Médi & baixa (ec & ômico) & Média & aixa (ec & & & Média & & & Média & \\
\hline Estratégia de crescimento & & & & & & & & & & & iversifica & & & & & & & & & & \\
\hline \begin{tabular}{|l|}
$\begin{array}{l}\text { Modelo de negócio predominante para } \\
\text { expansão de produtos }\end{array}$ \\
\end{tabular} & & & & & & & & & & Deser & olviment & róprio & & & & & & & & & \\
\hline $\begin{array}{l}\text { Modelo de negócio predominante para } \\
\text { expansão geográfica }\end{array}$ & & & & & & & & & & Deser & olviment & róprio & & & & & & & & & \\
\hline Indicadores operacionais e de desen & nho & & & & & & & & & & & & & & & & & & & & \\
\hline Receita - índice base 100 (ano 2007) & & $n / a$ & & & $\mathrm{n} / \mathrm{a}$ & & & 100 & & & 174 & & & 174 & & & 174 & & & n/a & \\
\hline Lucro - índice base 100 (ano 2007) & & $\mathrm{n} / \mathrm{a}$ & & & $\mathrm{n} / \mathrm{a}$ & & & 100 & & & 40 & & & 233 & & & 182 & & & n/a & \\
\hline Margem Liquida da empresa & & $n / a$ & & & $\mathrm{n} / \mathrm{a}$ & & & $12 \%$ & & & $3 \%$ & & & $9 \%$ & & & $5 \%$ & & & $\mathrm{n} / \mathrm{a}$ & \\
\hline Margem Líquida do mercado & & $16 \%$ & & & $15 \%$ & & & $13 \%$ & & & $15 \%$ & & & $15 \%$ & & & $15 \%$ & & & n/a & \\
\hline $\begin{array}{l}\text { Retorno sobre o patrimônio Líquido da } \\
\text { empresa }\end{array}$ & & $\mathrm{n} / \mathrm{a}$ & & & $\mathrm{n} / \mathrm{a}$ & & & $10 \%$ & & & $2 \%$ & & & $12 \%$ & & & $8 \%$ & & & n/a & \\
\hline $\begin{array}{l}\text { Retorno sobre o patrimônio Liquido do } \\
\text { mercado }\end{array}$ & & $23 \%$ & & & $14 \%$ & & & $11 \%$ & & & $14 \%$ & & & $16 \%$ & & & $18 \%$ & & & $n / a$ & \\
\hline Observações & & & & & & & \begin{tabular}{|} 
Aber \\
\\
Lançame \\
Região \\
Paulo \\
segmentos
\end{tabular} & $\begin{array}{l}\text { ura de ca } \\
\text { M\&fBibove } \\
\text { tos conc } \\
\text { tertopoli } \\
\text { elitoral c } \\
\text { de média } \\
\text { renda. }\end{array}$ & $\begin{array}{l}\text { Ina } \\
\text { ados na } \\
\text { de são } \\
\text { tado, } \\
\text { édia-alta }\end{array}$ & $\begin{array}{r}\text { Expan } \\
\text { Ri } \\
\text { Lançamer } \\
\text { para os }\end{array}$ & $\begin{array}{l}\text { ano para za } \\
\text { eirão Pr. } \\
\text { o de emp } \\
\text { gmentos } \\
\text { popula }\end{array}$ & $\begin{array}{l}\text { lade de } \\
\text { SP. } \\
\text { ndimentos } \\
\text { nômico e }\end{array}$ & $\begin{array}{r}\text { Expansã } \\
\text { do } \\
\text { Lançamen } \\
\text { para os s }\end{array}$ & $\begin{array}{l}\text { oara a r } \\
\text { iraiba p } \\
\text { de emp } \\
\text { denentos } \\
\text { popula }\end{array}$ & $\begin{array}{l}\text { o do Vale } \\
\text { sta. } \\
\text { dimentos } \\
\text { nômico e }\end{array}$ & $\begin{array}{r}\text { Expansão } \\
\text { Manute } \\
\text { Iançame } \\
\text { popul } \\
\text { mun } \\
\text { Metropo } \\
\text { in }\end{array}$ & $\begin{array}{l}\text { ara o Dis } \\
\text { ão da es } \\
\text { o para o } \\
\text { e econn } \\
\text { ípios da } \\
\text { tana de } \\
\text { ior do }\end{array}$ & $\begin{array}{l}\text { o Federal. } \\
\text { tégia de } \\
\text { gmentos } \\
\text { co em } \\
\text { iazo } \\
\text { Paulo e } \\
\text { do }\end{array}$ & & & \\
\hline
\end{tabular}

Fonte: Elaboração do autor 


\subsubsection{GAFISA e TENDA}

A Gafisa no ano de 2006 já possuía um portfólio de produtos e mercados diversificado, quando comparada com as outras empresas do setor, resultado do início de uma estratégia de diversificação iniciada em 2004 e ancorada no desenvolvimento de parcerias locais.

Em 2006, a empresa realizou lançamentos em 10 cidades, com destaque para São Paulo e Rio de Janeiro que, juntas, representaram $73 \%$ do portfólio de lançamentos em volume estimado de venda. A maioria dos lançamentos foram destinados ao público de média-baixa a média-alta renda.

Apesar de já possuir um portfólio relativamente diversificado, a empresa mostrava intenção de ampliar sua diversificação por meio de parcerias com empresas locais, conforme carta de Wilson Amaral, CEO da Gafisa.

\footnotetext{
"Nós estamos particularmente satisfeitos com as perspectivas de diversificação geográfica em virtude dos vários drivers de crescimento. A Gafisa tem utilizado a estratégia de buscar parcerias com incorporadoras locais, estabelecidas e bem-sucedidas. Ao agregar conhecimento local com a força da marca Gafisa, a companhia pode entrar em novos mercados e aproveitar a demanda e oferta local. Desde 2004, a empresa firmou novas parcerias, o que facilita o acesso da companhia a mercados estratégicos fora do Rio de Janeiro e São Paulo" (GAFISA, 2006. Pág. 5)
}

Neste mesmo ano a empresa concluiu a aquisição da Alphaville Urbanismo S.A, com o objetivo de diversificar-se em termos de mercados e segmentos de atuação.

O ano de 2007 foi significativamente importante para a empresa no que diz respeito à sua estratégia de crescimento e diversificação. Neste período a Gafisa expandiu sua atuação para o segmento de baixa renda, por meio da criação da subsidiária Fit Residencial, construtora com foco nos segmentos econômico e popular, e da constituição de joint-venture "Bairro Novo" com a construtora Odebrecht, em sociedade de $50 \%$ de participação entre as partes, com o objetivo de incorporar, 
construir e administrar projetos em larga escala para o segmento popular, em tipologia de bairros dotados de infraestrutura própria.

A tendência de crescimento e expansão de produtos continuou no ano de 2008, por meio da aquisição da empresa Tenda, especializada no segmento de baixa renda. A Tenda passou a ser a plataforma de baixa renda da empresa, incorporando a empresa Fit Residencial. Neste período, a joint venture "Bairro Novo" foi descontinuada, e parte dos empreendimentos incorporados à Tenda.

Ainda em 2007, a Gafisa adquiriu 70\% da empresa Cipesa Empreendimentos Imobiliários, com o objetivo de ampliar sua participação na região Nordeste do país, após período de parceria com a empresa.

Entre 2007 e 2008, para a entrada em outras regiões geográficas, em especial os estados da região Norte e Nordeste do Brasil, a empresa celebrou parcerias com empreendedores locais.

Nos anos seguintes não houve alteração significativas na diversificação do portfólio de produtos. A empresa se concentrou em administrar as aquisições e consolidar o crescimento nos novos mercados. 


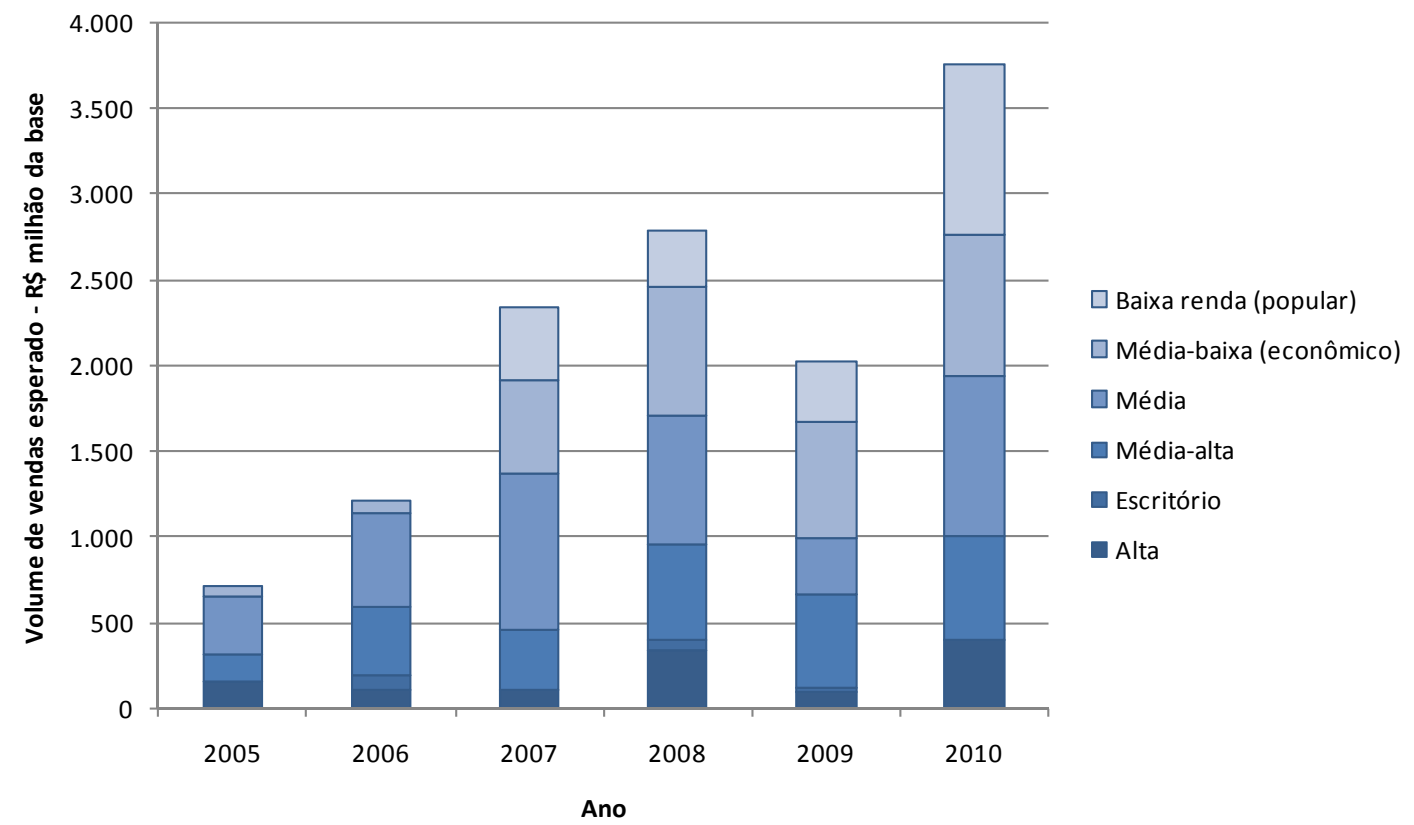

Gráfico 12 - Lançamentos por segmento de renda - Gafisa- em volume estimado de venda em R\$ milhão da base.

Fonte: elaboração do autor

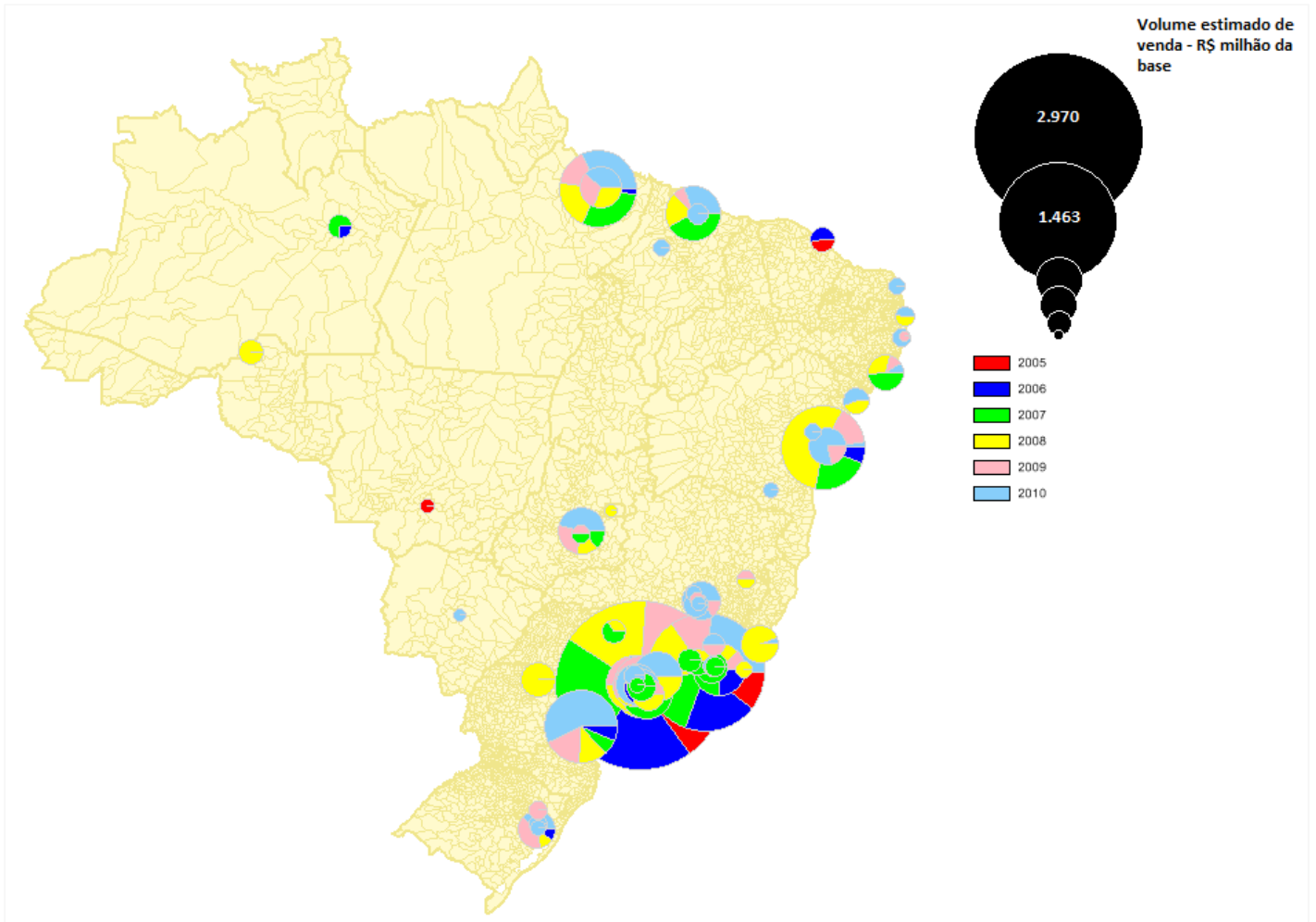

Figura 17 - Mapa de lançamentos da Empresa Gafisa.

Fonte: elaboração do autor 
Tabela 8 - Painel de Indicadores da empresa Gafisa

\begin{tabular}{|c|c|c|c|c|c|c|c|c|c|c|c|c|c|c|c|c|c|c|c|c|c|}
\hline Gafisa & \multicolumn{3}{|c|}{ Ano 2005} & \multicolumn{3}{|c|}{ Ano 2006} & \multicolumn{3}{|c|}{ Ano 2007} & \multicolumn{3}{|c|}{ Ano 2008} & \multicolumn{3}{|c|}{ Ano 2009} & \multicolumn{3}{|c|}{ Ano 2010} & \multicolumn{3}{|c|}{ Período 2005-2010 } \\
\hline Atuação geográfica & \multicolumn{3}{|c|}{ Estadual } & \multicolumn{3}{|c|}{ Nacional } & \multirow{2}{*}{\multicolumn{3}{|c|}{ Nacional }} & \multirow{2}{*}{\multicolumn{3}{|c|}{$\begin{array}{c}\text { Nacional } \\
\text { Reg. }\end{array}$}} & \multicolumn{3}{|c|}{ Nacional } & \multicolumn{3}{|c|}{ Nacional } & \multicolumn{3}{|c|}{ Nacional } \\
\hline \multirow{2}{*}{ Índice de diversificação geográfica } & Mun. & Reg. & Esta. & Mun. & Reg. & Esta. & & & & & & Esta. & Mun. & Reg. & Esta. & Mun. & Reg. & Esta. & Mun. & Reg. & Esta. \\
\hline & 0,55 & 0,44 & 0,44 & 0,68 & 0,59 & 0,59 & 0,87 & 0,74 & 0,71 & 0,91 & 0,80 & 0,76 & 0,85 & 0,69 & 0,67 & 0,89 & 0,78 & 0,73 & 0,89 & 0,76 & 0,72 \\
\hline Diversificação de produtos & \multicolumn{3}{|c|}{ Dominante } & \multicolumn{3}{|c|}{ Dominante } & \multicolumn{3}{|c|}{ Diversificada } & \multicolumn{3}{|c|}{ Diversificada } & \multicolumn{3}{|c|}{ Diversificada } & \multicolumn{3}{|c|}{ Diversificada } & \multicolumn{3}{|c|}{ Diversificada } \\
\hline Índice de diversificação de produto & \multicolumn{3}{|c|}{0,67} & \multicolumn{3}{|c|}{0,67} & \multicolumn{3}{|c|}{0,74} & \multicolumn{3}{|c|}{0,78} & \multicolumn{3}{|c|}{0,76} & \multicolumn{3}{|c|}{0,78} & \multicolumn{3}{|c|}{0,78} \\
\hline Segmento de renda & & Média & & & Média & & & Média & & & Média & & & Média-alt & & Baix & renda $(\mathrm{p}$ & & & Média & \\
\hline Estratégia de crescimento & & & & & & & & & & & versifica & & & & & & & & & & \\
\hline $\begin{array}{l}\text { Modelo de negócio predominante para } \\
\text { expansão de produtos }\end{array}$ & & & & & & & & & & & Aquisiç̧ã & & & & & & & & & & \\
\hline $\begin{array}{l}\text { Modelo de negócio predominante para } \\
\text { expansão geográfica }\end{array}$ & & & & & & & & & & & Parceri & & & & & & & & & & \\
\hline Indicadores operacionais e de dese & enho & & & & & & & & & & & & & & & & & & & & \\
\hline Receita - índice base 100 (ano 2005) & & 100 & & & 141 & & & 242 & & & 336 & & & 584 & & & 719 & & & n/a & \\
\hline Lucro - índice base 100 (ano 2005) & & 100 & & & 160 & & & 334 & & & 891 & & & 521 & & & 1.603 & & & n/a & \\
\hline Margem Líquida da empresa & & $5 \%$ & & & $6 \%$ & & & $7 \%$ & & & $14 \%$ & & & $5 \%$ & & & $12 \%$ & & & n/a & \\
\hline Margem Líquida do mercado & & $16 \%$ & & & $15 \%$ & & & $13 \%$ & & & $15 \%$ & & & $15 \%$ & & & $15 \%$ & & & n/a & \\
\hline $\begin{array}{l}\text { Retorno sobre o patrimônio Líquido da } \\
\text { empresa }\end{array}$ & & $11 \%$ & & & $8 \%$ & & & $8 \%$ & & & $16 \%$ & & & $7 \%$ & & & $14 \%$ & & & n/a & \\
\hline $\begin{array}{l}\text { Retorno sobre o patrimônio Liquido do } \\
\text { mercado }\end{array}$ & & $23 \%$ & & & $14 \%$ & & & $11 \%$ & & & $14 \%$ & & & $16 \%$ & & & $18 \%$ & & & $n / a$ & \\
\hline Observações & $\begin{array}{c}\text { Maior co } \\
\text { metrop } \\
\text { Rio } \\
\text { lançam }\end{array}$ & $\begin{array}{l}\text { entraçã } \\
\text { anas de } \\
\text { aneiro. } \\
\text { os em C } \\
\text { rtaleza. }\end{array}$ & $\begin{array}{l}\text { s regiões } \\
\text { Paulo e } \\
\text { izou } \\
\text { ź-MT e }\end{array}$ & & $\begin{array}{l}\text { Ira de cz } \\
\text { M\&FBov }\end{array}$ & & $\begin{array}{r}\text { Expan } \\
\text { diversos } \\
\text { país por } \\
\text { empres } \\
\text { produ } \\
\text { ventur } \\
\text { atuaçãa }\end{array}$ & $\begin{array}{l}\text { ão geográ } \\
\text { stados do } \\
\text { neio de pa } \\
\text { locais. E } \\
\text { s por mei } \\
\text { com Odet } \\
\text { no segmer } \\
\text { Bairro No }\end{array}$ & $\begin{array}{l}\text { para } \\
\text { e NO do } \\
\text { ias com } \\
\text { nsão de } \\
\text { ejoint } \\
\text { h para } \\
\text { oopular }\end{array}$ & $\begin{array}{r}\text { Intensi } \\
\text { geográfic } \\
\text { RS e o } \\
\text { Brasileiro } \\
\text { aquisiç } \\
\text { especi }\end{array}$ & $\begin{array}{l}\text { cação da } \\
\text { entrada } \\
\text { eros estata } \\
\text { Expansão } \\
\text { oda emp } \\
\text { izada no } \\
\text { popula }\end{array}$ & $\begin{array}{l}\text { lansão } \\
\text { estado de } \\
\text { do NE } \\
\text { produtos: } \\
\text { Tenda, } \\
\text { mento }\end{array}$ & 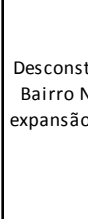 & $\begin{array}{l}\text { uçãa da ja } \\
\text { o. Intensi } \\
\text { egaráfica } \\
\text { parcerias }\end{array}$ & $\begin{array}{l}\text { nt venture } \\
\text { accăo da } \\
\text { rr meio de }\end{array}$ & $\begin{array}{c}\text { Intensi } \\
\text { geográfica } \\
\text { Intensifi } \\
\text { produtos }\end{array}$ & $\begin{array}{l}\text { :ação da } \\
\text { or meio } \\
\text { ção da } \\
\text { ry meio d } \\
\text { Fit-Tend }\end{array}$ & $\begin{array}{l}\text { vansão } \\
\text { parcerias. } \\
\text { insão de } \\
\text { ataforma }\end{array}$ & & & \\
\hline
\end{tabular}

Fonte: Elaboração do autor 


\section{Tenda}

A construtora Tenda iniciou suas atividades em 1994, concentrada inicialmente no estado de Minas Gerais, tendo expandido suas operações para São Paulo no ano de 1999.

A empresa abriu capital na BM\&FBovespa no ano de 2007. Neste mesmo ano, a empresa possuía concentração de produtos nos segmentos popular e econômico.

Neste mesmo documento, a empresa firmou sua estratégia de crescimento baseado na expansão geográfica para aglomerações urbanas que concentrem mais de 500 mil habitantes, e na especialização no segmento de baixa renda. Neste último, a empresa visava ao atendimento da significativa demanda do segmento popular por habitações, além do ganho operacional, cuja tipologia dos empreendimentos permite a industrialização e escala de construção.

No ano de 2006, a empresa realizou lançamentos nos estados de São Paulo e Minas Gerais. Em 2007, a empresa expandiu seu portfólio de lançamentos para os estados do Rio de Janeiro, Goiás e Bahia, além de expandir de sobremaneira o volume de lançamentos (variação de 1.359\% entre 2007 e 2006, em VGV). Em 2008, e empresa incorporou a Fit Residencial, após ser adquirida pela empresa Gafisa. Neste ano, a empresa agregou ao seu portfólio de lançamentos todos os empreendimentos da Fit, empresa voltada ao segmento de média-baixa renda (econômico), o que propiciou à Tenda um incremento na diversificação do seu portfólio segundo o vetor segmento de renda. Em 2009, não houve alterações significativas na diversificação do portfólio de lançamentos da empresa. 


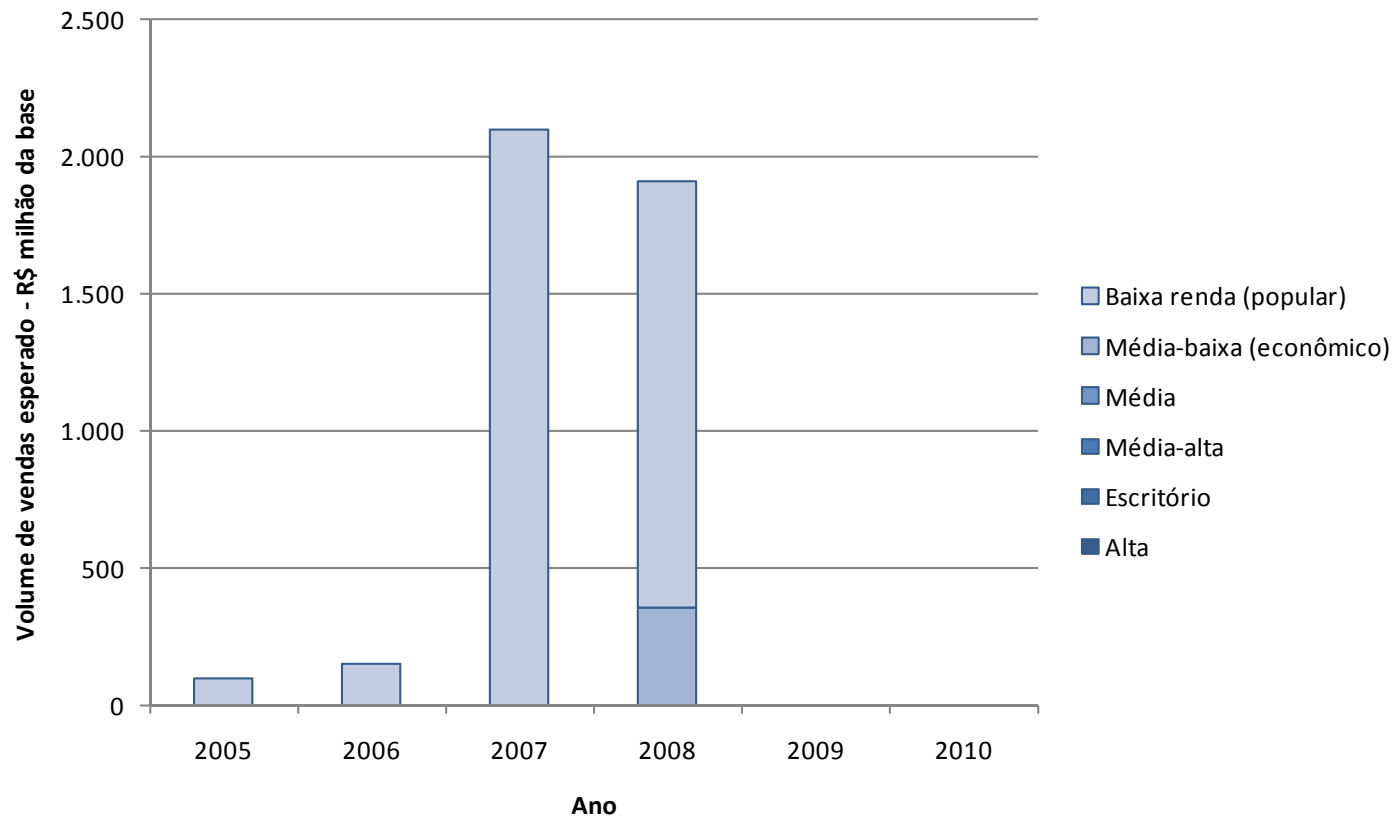

Gráfico 13 - Lançamentos por segmento de renda - Tenda - em volume estimado de venda em R \$ milhão da base.

Fonte: elaboração do autor

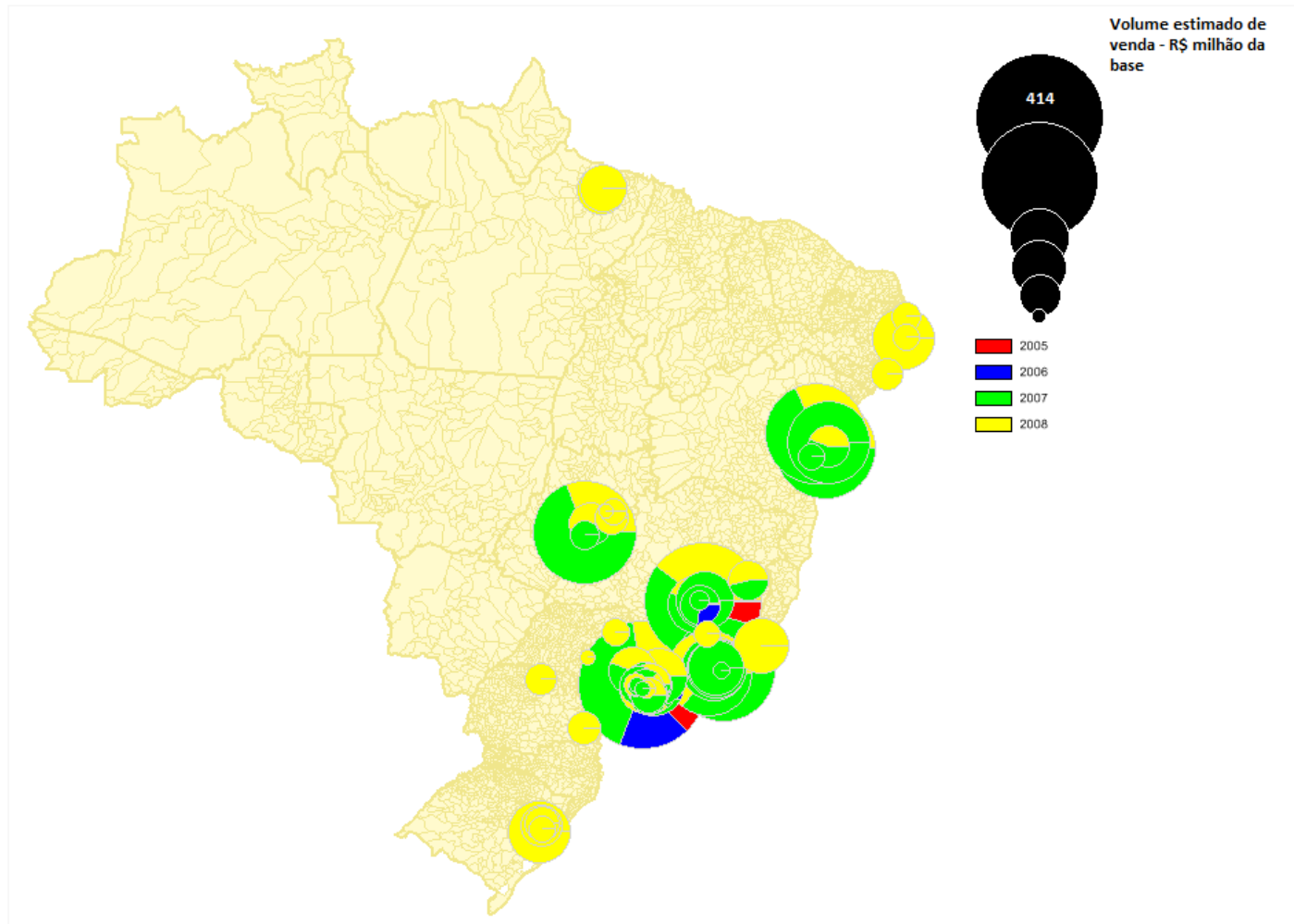

Figura 18 - Mapa de lançamentos da Empresa Tenda

Fonte: elaboração do autor 
Tabela 9 - Painel de Indicadores da empresa Tenda

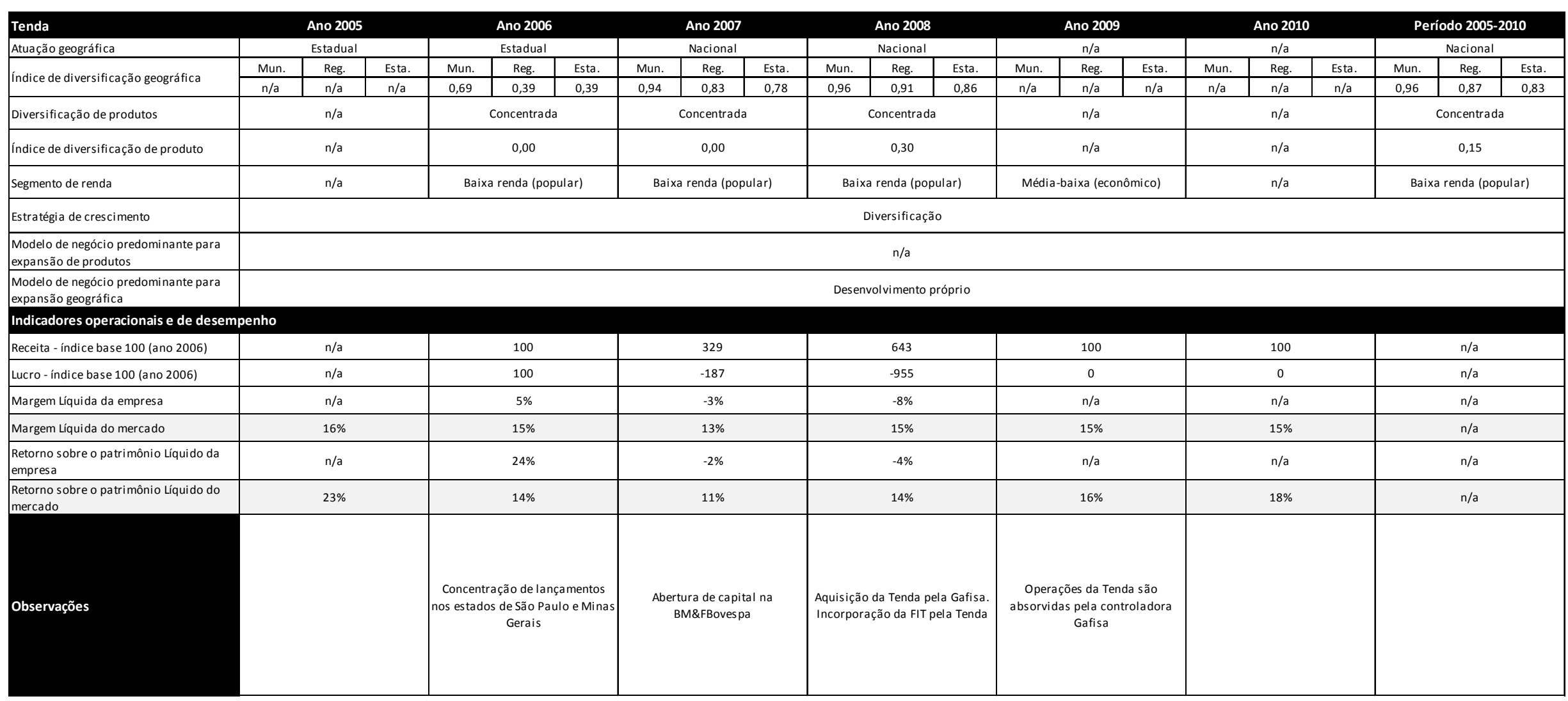

Fonte: Elaboração do autor 


\subsubsection{CR2}

A empresa CR2 Empreendimentos Imobiliários S.A foi constituída no ano de 2006, e sua abertura de capital na BM\&FBovespa ocorrida em 2007.

Nos dois primeiros anos de sua constituição, a empresa apresentou portfólio de empreendimentos concentrado na Região Metropolitana do Rio de Janeiro e no segmento de renda econômico.

Em 2008 e 2009, a empresa expandiu sua atuação para o estado de São Paulo, particularmente para a região metropolitana da capital, mantendo sua estratégia de atuação no segmento econômico.

A CR2, ao contrário da maioria de suas concorrentes listadas na BM\&FBovespa, não possui construtora própria; assim, terceiriza todas as atividades de construção e corretagem.

A empresa tem como modelo de negócio estabelecer parcerias com empresas de nichos, com competência de mercado quando o objetivo é a entrada numa nova região geográfica, ou de produtos, quando o desenvolvimento do empreendimento é destinado a um segmento de requer conhecimentos específicos.

Segundo informações disponíveis no prospecto de abertura de capital da empresa, e divulgação dos resultados do exercício de 2006 e 2007 (CR2, 2007 ; CR2, 2006 ; CR2 2007b), o modelo de incorporação pura e parcerias permite à empresa as seguintes vantagens

- Diluição de riscos: possibilidade de ofertar diferentes produtos em diferentes mercados, simultaneamente e com maior agilidade, reduzindo a concentração do portfólio a segmentos e mercados específicos;

- Maior flexibilidade: a ausência de estrutura fixa de engenharia, arquitetura e vendas permite maior agilidade e eficiência tanto na entrada em mercados promissores como na saída de mercados em recessão; 
- Maior conhecimento e oportunidades: as parcerias permitem acesso rápido e eficiente a profissionais altamente qualificados, além do contato com outras partes abrir novas oportunidades de negócios;

- Menor custo fixo: quadro reduzido de funcionários resulta em estrutura operacional de baixo custo fixo.

Em 2007, a empresa realizou empreendimentos para os segmentos de renda média e econômico na região metropolitana do Rio de Janeiro. Em 2008, a empresa entrou no mercado da região metropolitana de São Paulo, nas cidades de Guarulhos e Santo André. Para tanto, estabeleceu parceria com a empresa YPS, construtora com atuação local e com portfólio especializado na construção de habitação de baixa renda.

No ano de 2008, 2009 e 2010 manteve sua concentração no segmento econômico e nas regiões metropolitanas de São Paulo e Rio de Janeiro, sempre atuando com parceiros para a co-incorporação e empresas terceirizadas para as atividades de projeto, construção e vendas.

Apesar de a empresa ter apresentado o modelo de incorporação pura e de parcerias como mais flexível e eficiente em relação aos modelos praticados pelas empresas concorrentes, a CR2 adotou uma estratégia de concentração de produtos e mercados, ao ampliar o número de lançamentos para o segmento econômico, limitado, em sua maioria, aos municípios de Guarulhos-SP, Santo André-SP, Rio de Janeiro-RJ e Nova Iguaçu-RJ. 


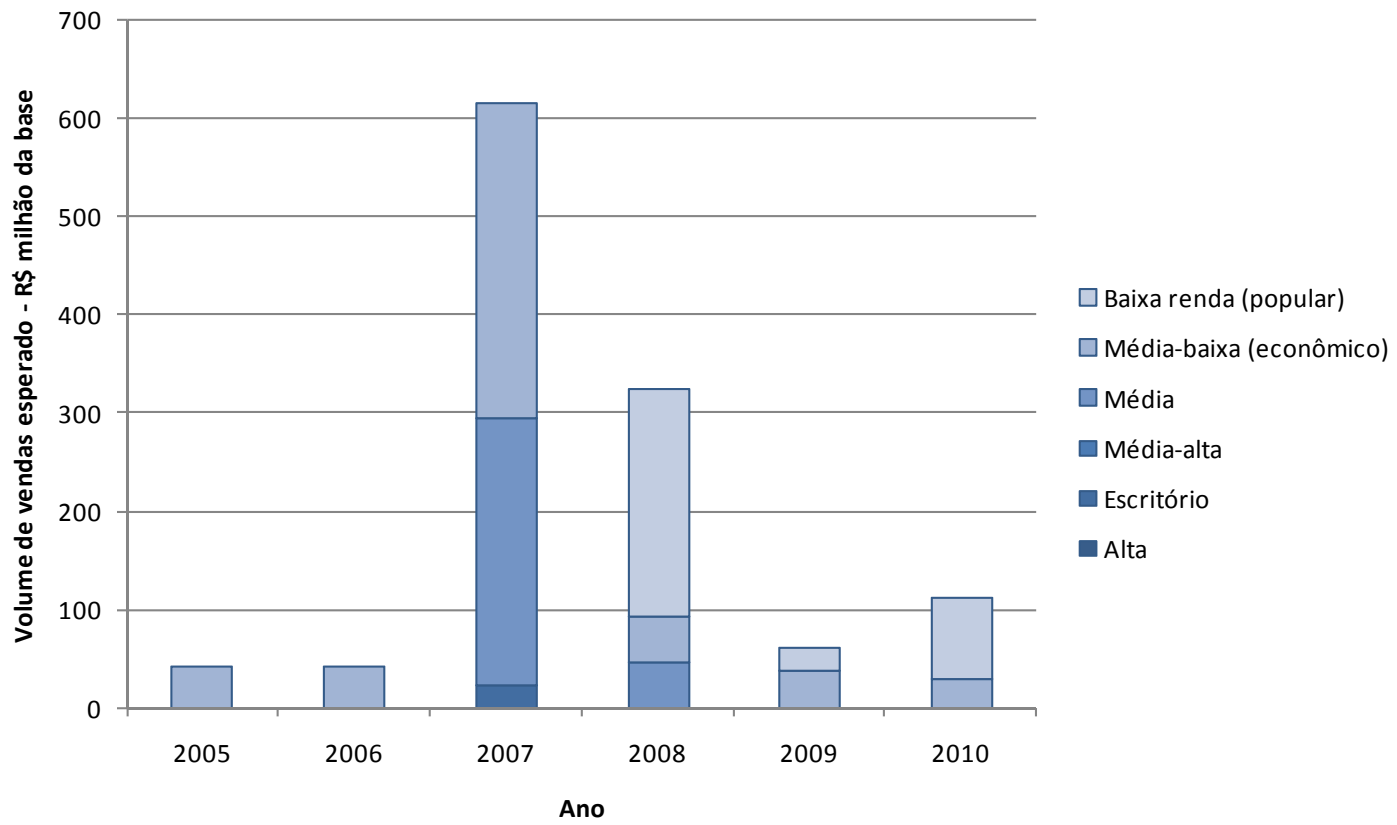

Gráfico 14 - Lançamentos por segmento de renda - CR2 - em volume estimado de venda em R \$ milhão da base

Fonte: elaboração do autor

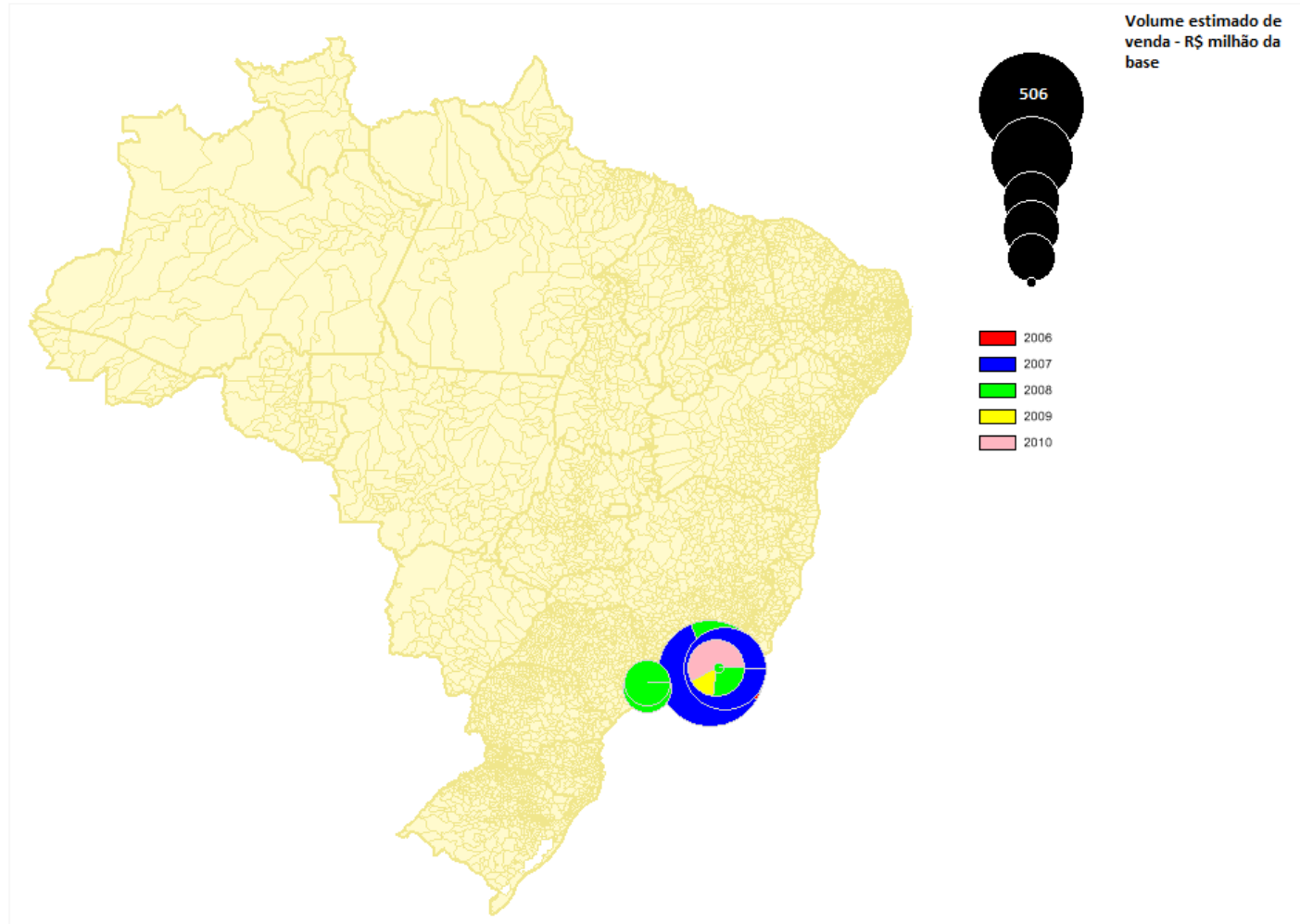

Figura 19 - Mapa de lançamentos da empresa CR2

Fonte: elaboração do autor 
Tabela 10 - Painel de Indicadores da empresa CR2

\begin{tabular}{|c|c|c|c|c|c|c|c|c|c|c|c|c|c|c|c|c|c|c|c|c|c|}
\hline CR2 & & no 200 & & & Ano 20 & & & Ano 200 & & & Ano 20 & & & Ano 20 & & & Ano 201 & & & do 2005 & \\
\hline Atuação geográfica & & $\mathrm{n} / \mathrm{a}$ & & & Municip & & & Regional & & & Estadua & & & Estadua & & & Regiona & & & Estadual & \\
\hline |índice de diversificacãão geográfica & Mun. & Reg. & Esta. & Mun. & Reg. & Esta. & Mun. & Reg. & Esta. & Mun. & Reg. & Esta. & Mun. & Reg. & Esta. & Mun. & Reg. & Esta. & Mun. & Reg. & Esta. \\
\hline 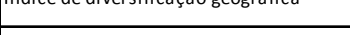 & n/a & $\mathrm{n} / \mathrm{a}$ & $\mathrm{n} / \mathrm{a}$ & 0,00 & 0,00 & 0,00 & 0,50 & 0,00 & 0,00 & 0,71 & 0,50 & 0,50 & 0,46 & 0,46 & 0,46 & 0,39 & 0,00 & 0,00 & 0,71 & 0,28 & 0,28 \\
\hline Diversificação de produtos & & $n / a$ & & & oncentra & & & oncentra & & & incentra & & & oncentr. & & & oncentra & & & Dominant & \\
\hline Índice de diversificação de produto & & $n / a$ & & & 0,00 & & & 0,53 & & & 0,45 & & & 0,46 & & & 0,39 & & & 0,67 & \\
\hline Segmento de renda & & n/a & & Média & aixa (ec & mico) & Média & aixa (ec & & & renda $(\mathrm{p}$ & & Média & paixa (ec & nico) & & renda $(\mathrm{f}$ & & Médi & paixa (ecc & mico) \\
\hline Estratégia de crescimento & & & & & & & & & & & iversifica & & & & & & & & & & \\
\hline $\begin{array}{l}\text { Modelo de negócio predominante para } \\
\text { expansão de produtos }\end{array}$ & & & & & & & & & & & Parcerie & & & & & & & & & & \\
\hline $\begin{array}{l}\text { Modelo de negócio predominante para } \\
\text { expansão geográfica }\end{array}$ & & & & & & & & & & & Parceri & & & & & & & & & & \\
\hline Indicadores operacionais e de desen & & & & & & & & & & & & & & & & & & & & & \\
\hline Receita - índice base 100 (ano 2007) & & $\mathrm{n} / \mathrm{a}$ & & & $\mathrm{n} / \mathrm{a}$ & & & 100 & & & 480 & & & 600 & & & 868 & & & n/a & \\
\hline Lucro - índice base 100 (ano 2007) & & n/a & & & $\mathrm{n} / \mathrm{a}$ & & & 100 & & & 39 & & & 39 & & & 120 & & & $\mathrm{n} / \mathrm{a}$ & \\
\hline Margem Líquida da empresa & & n/a & & & $\mathrm{n} / \mathrm{a}$ & & & $11 \%$ & & & $16 \%$ & & & $5 \%$ & & & $10 \%$ & & & $\mathrm{n} / \mathrm{a}$ & \\
\hline Margem Líquida do mercado & & $16 \%$ & & & $15 \%$ & & & $13 \%$ & & & $15 \%$ & & & $15 \%$ & & & $15 \%$ & & & $\mathrm{n} / \mathrm{a}$ & \\
\hline $\begin{array}{l}\text { Retorno sobre o patrimônio Líquido da } \\
\text { empresa }\end{array}$ & & $\mathrm{n} / \mathrm{a}$ & & & $\mathrm{n} / \mathrm{a}$ & & & $3 \%$ & & & $10 \%$ & & & $4 \%$ & & & $11 \%$ & & & n/a & \\
\hline $\begin{array}{l}\text { Retorno sobre o patrimônio Líquido do } \\
\text { mercado }\end{array}$ & & $23 \%$ & & & $14 \%$ & & & $11 \%$ & & & $14 \%$ & & & $16 \%$ & & & $18 \%$ & & & $\mathrm{n} / \mathrm{a}$ & \\
\hline Observações & & & & $\begin{array}{l}\text { Atuação ó } \\
\text { no munici }\end{array}$ & $\begin{array}{l}\text { segmen } \\
\text { o do Rio }\end{array}$ & $\begin{array}{l}\text { conômico } \\
\text { aneiro-RJ. }\end{array}$ & $\begin{array}{r}\text { Aber } \\
\text { Concentr } \\
\text { médiar } \\
\text { Regiảo N }\end{array}$ & $\begin{array}{l}\text { ra de ca } \\
\text { \&\&Fbove } \\
\text { ão nos s } \\
\text { ida e eco } \\
\text { ropolita } \\
\text { Janeiro }\end{array}$ & $\begin{array}{l}\text { na } \\
\text { entos de } \\
\text { ico na } \\
\text { o Rio de }\end{array}$ & $\begin{array}{l}\text { Entrada } \\
\text { Metrop } \\
\text { Parceri }\end{array}$ & $\begin{array}{l}\text { o mercad } \\
\text { litana de } \\
\text { com a er } \\
\text { construtc }\end{array}$ & $\begin{array}{l}\text { Região } \\
\text { Paulo. } \\
\text { sa YPS }\end{array}$ & $\begin{array}{r}\text { Lançame } \\
\text { econ } \\
\text { metropoli }\end{array}$ & $\begin{array}{l}\text { tos para } \\
\text { mico nas } \\
\text { na desâ } \\
\text { de Janei }\end{array}$ & $\begin{array}{l}\text { gmento } \\
\text { óes } \\
\text { ulo e Rio }\end{array}$ & $\begin{array}{r}\text { Lançam } \\
\text { econ } \\
\text { metropoli }\end{array}$ & $\begin{array}{l}\text { os para } \\
\text { nnico nas } \\
\text { na de Sã } \\
\text { de Janei }\end{array}$ & $\begin{array}{l}\text { egmento } \\
\text { iâes } \\
\text { ullo e Rio }\end{array}$ & & & \\
\hline
\end{tabular}

Fonte: Elaboração do autor 


\subsubsection{PDG}

A PDG Realty foi a empresa a realizar o maior volume de empreendimentos no ano de 2010, em volume esperado de vendas, segundo dados levantadas na presente dissertação.

Desde 2005, a empresa cresceu 45 vezes em receita bruta, saindo de um portfólio concentrado no segmento econômico e nas cidades de São Paulo e Rio de Janeiro para uma companhia nacional e diversificada.

Como estratégia de crescimento e diversificação do portfólio, a empresa fez uso predominante dos modelos de parcerias, aquisições e joint ventures. No primeiro, a empresa realizou co-incorporação direta com parceiros em nível das sociedades de propósito específico dos empreendimentos. Nas aquisições e joint ventures, ou investimentos de portfólio como denominado pela própria empresa, a companhia empreendeu através da operação e gestão direta de outras empresas. Ambos os modelos ainda estão presentes e fazem parte da estratégia declarada da empresa.

Segundo informações disponíveis no prospecto de emissão primária de ações (PDG, 2007), a empresa adota o modelo de parcerias como uma estratégia de relacionamento gradual com a empresa parceira. Assim, na fase inicial, desenvolve-se a coincorporação de empreendimentos com o parceiro por meio da participação direta na sociedade de propósito específico. Havendo interesse e condições favoráveis entre as partes, num segundo momento pode ser celebrado contrato com o objetivo de realizar estratégias conjuntas de desenvolvimento de empreendimentos em longo prazo. Numa etapa posterior, poderá ser firmada sociedade por meio do modelo de joint venture ou mesmo aquisição parcial ou total do parceiro. Segundo a empresa, a estratégia reduz riscos, pois permite aumentar o conhecimento do parceiro e do novo negócio de maneira gradual.

Em 2006, a empresa realizou lançamentos imobiliários nas cidades de São Paulo, Rio de Janeiro e Salvador, por meio das empresas Goldfarb, CHL e Jazz, por meio dos modelos de co-incorporação. Neste ano a companhia se classificava como uma 
companhia de atuação estadual e portfólio de produtos dominante no segmento de renda média.

Em 2007, como estratégia de entrada em nova regiões geográficas, a empresa adquiriu participação nas companhias CHL, Cipasa e Lindencorp, e estabeleceu parcerias com as empresas Abaurre, Pinto de Almeida Engenharia, LN empreendimentos imobiliários e Dominus. No mesmo ano, como estratégia para ampliação da participação no segmento econômico, empresa adquiriu o controle da construtora e incorporadora Goldfarb.

Em 2008, após firmar parceria com a empresa Terrano empreendimentos Imobiliários, passou a realizar operações nas cidades de Cuiabá e Goiânia. Ao mesmo tempo, ampliou suas operações no estado de São Paulo, por meio de lançamentos realizados pela Goldfarb e Cipasa nas cidades de São José dos Campos, Jundiaí, Osasco, Barueri e Ribeirão Preto, esta última através da Joint-venture com a empresa Habiart Barc. Como consequiência, aumentou a exposição ao segmento de média-baixa renda, ao destinar $65 \%$ do seu portfólio de lançamentos, em volume esperado de venda.

Em 2009 a empresa exerceu opção de compra que detinha contra a CHL, passando a deter $100 \%$ de seu controle. Consolidou, assim, sua base operacional por meio das empresas Goldfarb e CHL. A empresa ampliou o número de filiais da Goldfarb e agregou às suas operações as cidades de Porto Alegre e São José do Rio Preto. A exposição ao segmento de média-baixa renda chegou a aproximadamente $80 \%$ do portfólio de lançamentos.

Em 2010, a empresa aumentou o número de mercados por meio de parceria com a empresa Leal Moreira, que permitiu a entrada na cidade de Belém-PA. No mesmo ano, adquiriu a companhia AGRE, cujo volume de lançamentos em 2009 (aproximadamente R \$ 1,1 Bilhão em moeda da base), permitiu aumentar o volume de empreendimentos da companhia e sua diversificação de produtos, ao agregar ao portfólio da PDG os empreendimentos destinados aos segmentos de renda média e média-alta da AGRE. 
Conforme dados apresentados no quadro abaixo, o índice que representa a diversificação de produtos aumentou de 0,52 em 2009 para 0,77 em 2010, caracterizando a PDG como uma das empresas de maior diversificação de produtos entre as listadas no Novo Mercado da BM\&FBovespa.

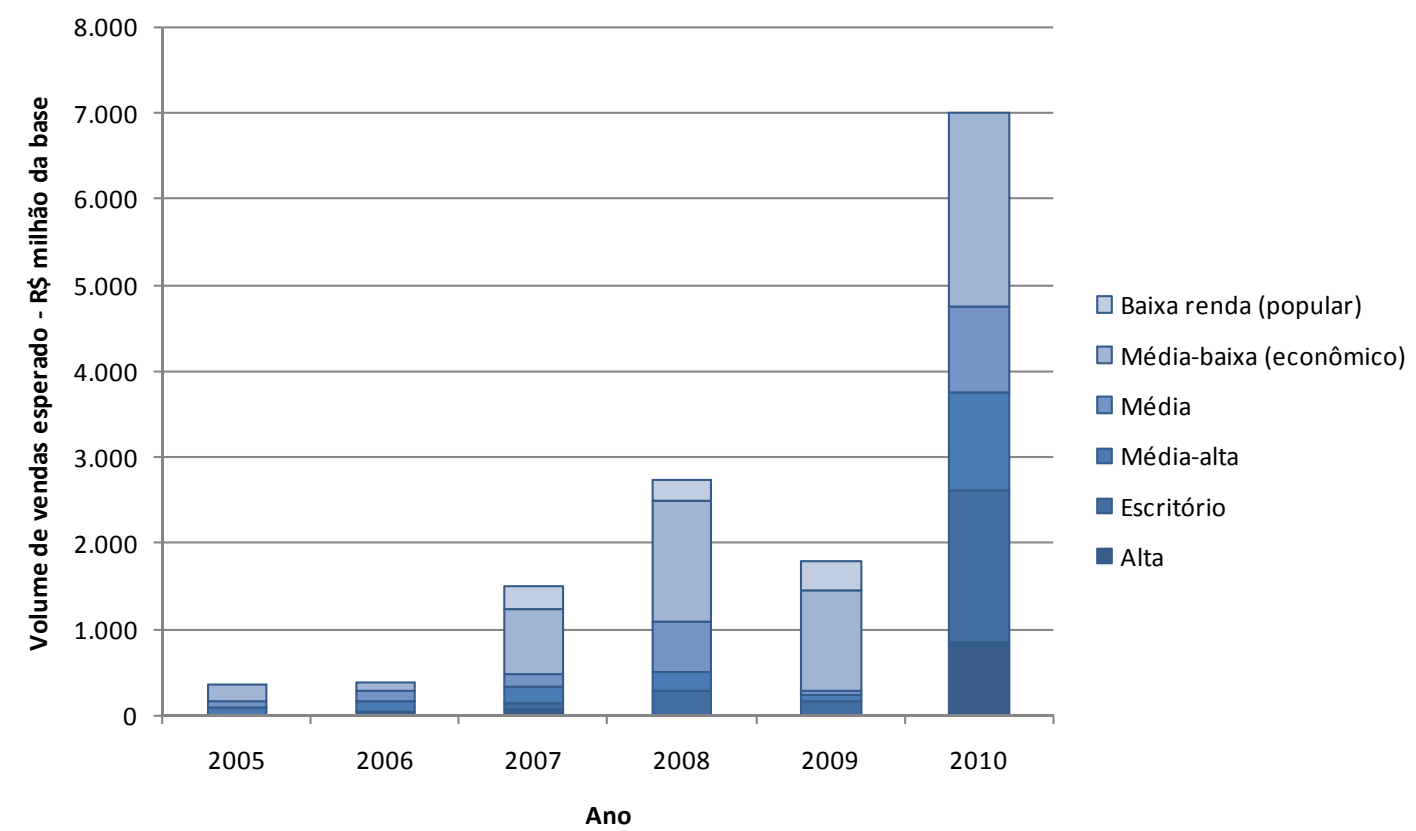

Gráfico 15 - Lançamentos por segmento de renda - PDG - em volume estimado de venda em R\$ milhão da base

Fonte: elaboração do autor

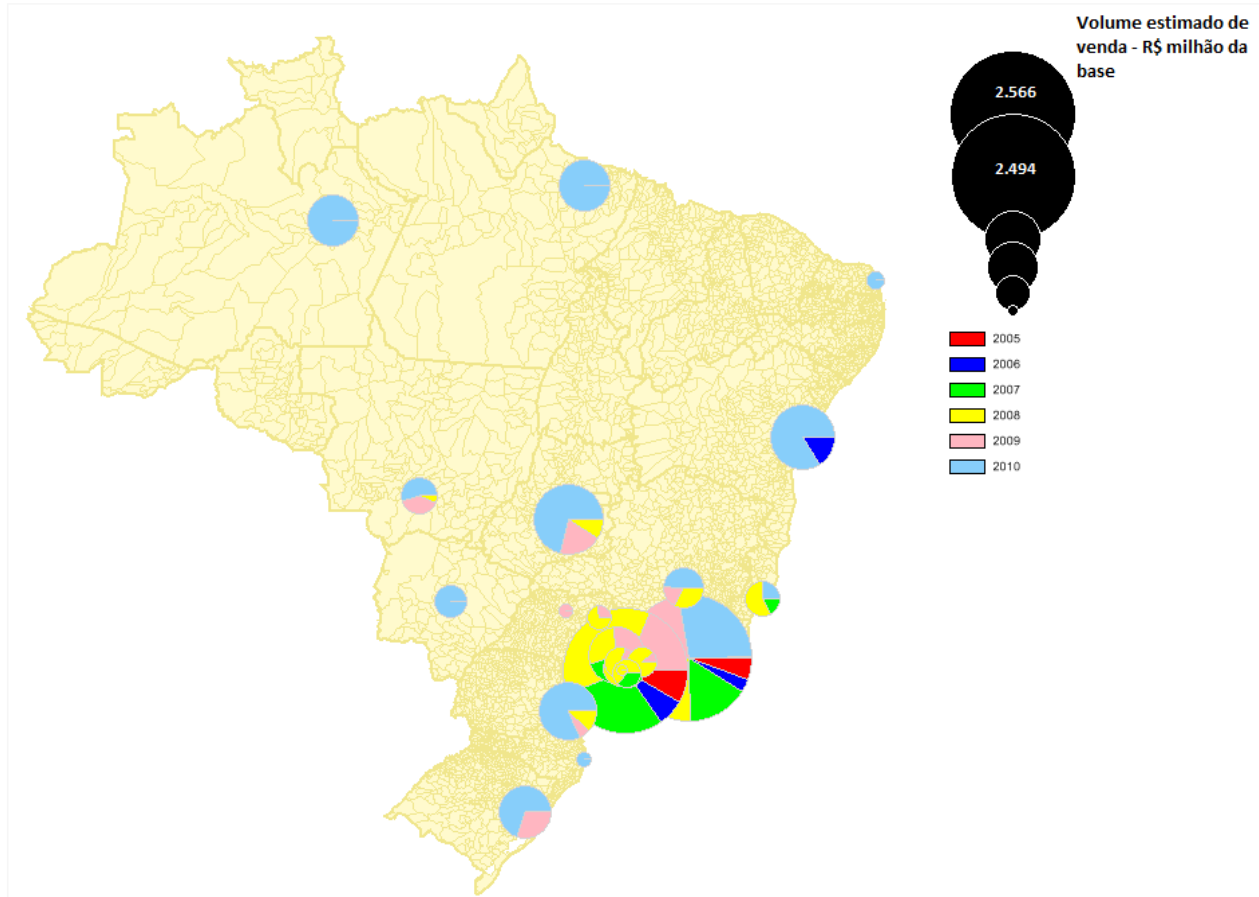

Figura 20 - Mapa de lançamentos da empresa PDG

Fonte: elaboração do autor 
Tabela 11 - Painel de Indicadores da empresa PDG

\begin{tabular}{|c|c|c|c|c|c|c|c|c|c|c|c|c|c|c|c|c|c|c|c|c|c|}
\hline PDG & & Ano 20 & & & Ano 200 & & & Ano 200 & & & Ano 200 & & & Ano 200 & & & Ano 20 & & & do 2005 & \\
\hline Atuação geográfica & & Estadua & & & Naciona & & & Estadua & & & Naciona & & & Naciona & & & Nacione & & & Naciona & \\
\hline & Mun. & Reg. & Esta. & Mun. & Reg. & Esta. & Mun. & Reg. & Esta. & Mun. & Reg. & Esta. & Mun. & Reg. & Esta. & Mun. & Reg. & Esta. & Mun. & Reg. & Esta. \\
\hline |indice de diversiticaçao geografica & 0,48 & 0,48 & 0,48 & 0,64 & 0,64 & 0,64 & 0,66 & 0,60 & 0,43 & 0,80 & 0,73 & 0,55 & 0,83 & 0,78 & 0,68 & 0,87 & 0,87 & 0,77 & 0,85 & 0,83 & 0,70 \\
\hline Diversificação de produtos & & Dominan & & & versifice & & & Dominan & & & Dominan & & & oncentra & & & versific & & & versifica & \\
\hline Índice de diversificação de produto & & 0,62 & & & 0,72 & & & 0,68 & & & 0,67 & & & 0,52 & & & 0,77 & & & 0,74 & \\
\hline Segmento de renda & Médi & paixa (ec & mico) & & Média & & Média & aixa (ecc & nico) & Média & paixa (ecc & mico) & Média & baixa (ecc & mico) & Média & aixa (ec & nico) & Médi & aixa (ecc & mico) \\
\hline Estratégia de crescimento & & & & & & & & & & & versifica & & & & & & & & & & \\
\hline $\begin{array}{l}\text { Modelo de negócio predominante para } \\
\text { expansão de produtos }\end{array}$ & & & & & & & & & & & Aquisiçãa & & & & & & & & & & \\
\hline $\begin{array}{l}\text { Modelo de negócio predominante para } \\
\text { expansão geográfica }\end{array}$ & & & & & & & & & & & Aquisiçăă & & & & & & & & & & \\
\hline Indicadores operacionais e de deser & enho & & & & & & & & & & & & & & & & & & & & \\
\hline Receita - índice base 100 (ano 2006)* & & $\mathrm{n} / \mathrm{a}$ & & & 100 & & & 502 & & & 1.077 & & & 1.735 & & & 4.575 & & & $\mathrm{n} / \mathrm{a}$ & \\
\hline Lucro - índice base 100 (ano 2006)* & & $\mathrm{n} / \mathrm{a}$ & & & 100 & & & 1.180 & & & 3.026 & & & 5.607 & & & 13.094 & & & $\mathrm{n} / \mathrm{a}$ & \\
\hline Margem Líquida da empresa & & $0 \%$ & & & $5 \%$ & & & $12 \%$ & & & $15 \%$ & & & $17 \%$ & & & $15 \%$ & & & $\mathrm{n} / \mathrm{a}$ & \\
\hline Margem Líquida do mercado & & $16 \%$ & & & $15 \%$ & & & $13 \%$ & & & $15 \%$ & & & $15 \%$ & & & $15 \%$ & & & $\mathrm{n} / \mathrm{a}$ & \\
\hline $\begin{array}{l}\text { Retorno sobre o patrimônio Líquido da } \\
\text { empresa }\end{array}$ & & $0 \%$ & & & $5 \%$ & & & $9 \%$ & & & $13 \%$ & & & $15 \%$ & & & $18 \%$ & & & $\mathrm{n} / \mathrm{a}$ & \\
\hline $\begin{array}{l}\text { Retorno sobre o patrimônio Liquido do } \\
\text { mercado }\end{array}$ & & $23 \%$ & & & $14 \%$ & & & $11 \%$ & & & $14 \%$ & & & $16 \%$ & & & $18 \%$ & & & $\mathrm{n} / \mathrm{a}$ & \\
\hline Observações & $\begin{array}{l}\text { Atuas } \\
\text { municipi } \\
\text { Janeiro } \\
\text { baixa } \\
\text { Empreen } \\
\text { regime }\end{array}$ & $\begin{array}{l}\text { concen } \\
\text { de São } \\
\text { segmen } \\
\text { média-a } \\
\text { nentos e } \\
\text { parceria } \\
\text { empresa }\end{array}$ & $\begin{array}{l}\text { la nos } \\
\text { o e Rio de } \\
\text { de média- } \\
\text { enda. } \\
\text { tados em } \\
\text { noutras }\end{array}$ & $\begin{array}{l}\text { Lançamen } \\
\text { nas cida } \\
\text { de Janeir } \\
\text { me }\end{array}$ & $\begin{array}{l}\text { de empr } \\
\text { de São } \\
\text { 2le Salv } \\
\text { de parc }\end{array}$ & $\begin{array}{l}\text { dimentos } \\
\text { o-SP, Rio } \\
\text { r-BA por } \\
\text { s. }\end{array}$ & \begin{tabular}{|} 
Aber \\
BM\&FB \\
empre \\
Cipasa pa \\
Aquisi \\
expan \\
\end{tabular} & $\begin{array}{l}\text { ara de car } \\
\text { espa. Aqu } \\
\text { s CHL, Lin } \\
\text { expansã } \\
\text { o da Gol c } \\
\text { o para o } \\
\text { econômi }\end{array}$ & $\begin{array}{l}\text { na } \\
\text { ão das } \\
\text { corp e } \\
\text { ográfica. } \\
\text { para } \\
\text { nento }\end{array}$ & $\begin{array}{r}\text { Intensi } \\
\text { geog } \\
\text { segmentos } \\
\text { ecidades }\end{array}$ & $\begin{array}{l}\text { cação da } \\
\text { fica. Entr } \\
\text { le Goiás, } \\
\text { interior } \\
\text { São Paul }\end{array}$ & $\begin{array}{l}\text { ansão } \\
\text { nos } \\
\text { to Grosso } \\
\text { estado de }\end{array}$ & $\begin{array}{l}\text { Continui } \\
\text { foco no se } \\
\text { renda. Exp, } \\
\text { de MG, }\end{array}$ & $\begin{array}{l}\text { lada da e } \\
\text { mento de } \\
\text { ansão } \\
\text { S a par } \\
\text { S e Distri }\end{array}$ & $\begin{array}{l}\text { tégia de } \\
\text { dia-baixa } \\
\text { sestados } \\
\text { ederal. }\end{array}$ & $\begin{array}{r}\text { Aquis } \\
\text { emp } \\
\text { consoli } \\
\text { estado } \\
\text { Parana }\end{array}$ & $\begin{array}{l}\text { to da en } \\
\text { nddimen } \\
\text { z̃o da a } \\
\text { e Santa } \\
\text { quisiçã }\end{array}$ & $\begin{array}{l}\text { sa Ln } \\
\text { ara } \\
\text { aro nos } \\
\text { rina e } \\
\text { AGRE. }\end{array}$ & & & \\
\hline
\end{tabular}

Fonte: Elaboração do autor 


\subsubsection{MRV}

A empresa MRV engenharia e participações S.A é a companhia com o maior volume de lançamentos destinados aos segmentos econômico e popular entre as empresas de construção civil listadas na BM\&FBovespa, segundo dados levantados pelo próprio autor.

Ao longo do período 2005-2010, a empresa cresceu sua receita em 27 vezes, e saiu de uma companhia de atuação estadual, com presença majoritária nos estados de São Paulo e Minas Gerais, para uma companhia nacional, presente em 11 estados do país. Ao longo do período, a empresa manteve sua estratégia de concentração nos produtos destinados aos segmentos econômico e popular.

A MRV iniciou sua estratégia de crescimento antes de sua abertura de capital, ocorrida em 2007. Segundo informações obtidas no prospecto de emissão primária de ações da empresa (MRV, 2007), o modelo de expansão geográfica da companhia segue lógica de desenvolvimento interno de competências, ao alocar equipe interna destinadas exclusivamente para a expansão dos negócios em novas localidades, uma vez que, segundo a empresa, o mercado imobiliário requer o conhecimento da realidade específica de cada região.

As parcerias em novas regiões geográficas, quando ocorreram, foram com construtoras previamente selecionadas com base na especialização de produtos dos segmentos econômico e popular, independente da região de atuação da construtora.

Visando atender a um forte crescimento e, portanto, aumentar nossa capacidade de construção, temos desenvolvido parcerias com outros construtores e, atualmente, possuímos nove parceiros. Nossa estratégia é selecionar construtoras com reconhecida capacidade e conhecimento no segmento de Empreendimentos Residenciais Populares, independentemente de sua localidade de atuação, e, em seguida, montar acordos operacionais com cada uma delas, delimitando a respectiva área geográfica de atuação.(MRV, 2007. Pag. 147)

Assim, ao utilizar as parcerias para a construção dos empreendimentos apenas, e deixar o conhecimento de mercado para a equipe interna, o modelo de parceria da 
MRV é distinto ao modelo praticado pelas demais empresas objeto de estudo do presente trabalho, que fazem uso das parcerias não somente pelos recursos de construção, mas principalmente pelo conhecimento das peculiaridades locais, dos anseios da população e do acesso imediato a um landbank.

A empresa ainda adquiriu duas construtoras, a Prime Incorporações e Construções, e a Blás Engenharia; a primeira com atuação nos estados de Goiânia, Distrito Federal, Minas Gerais e interior de São Paulo, e a segunda no estado do Rio de Janeiro e Minas Gerais. As aquisições tiveram como objetivo acessar os mercados locais e utilizá-las como plataforma de construção nos novos mercados. As aquisições, porém, quando comparadas com o volume de empreendimentos das novas regiões mercados acessadas pela MRV no período, se tornam minoritárias na estratégia de expansão geográfica da companhia.

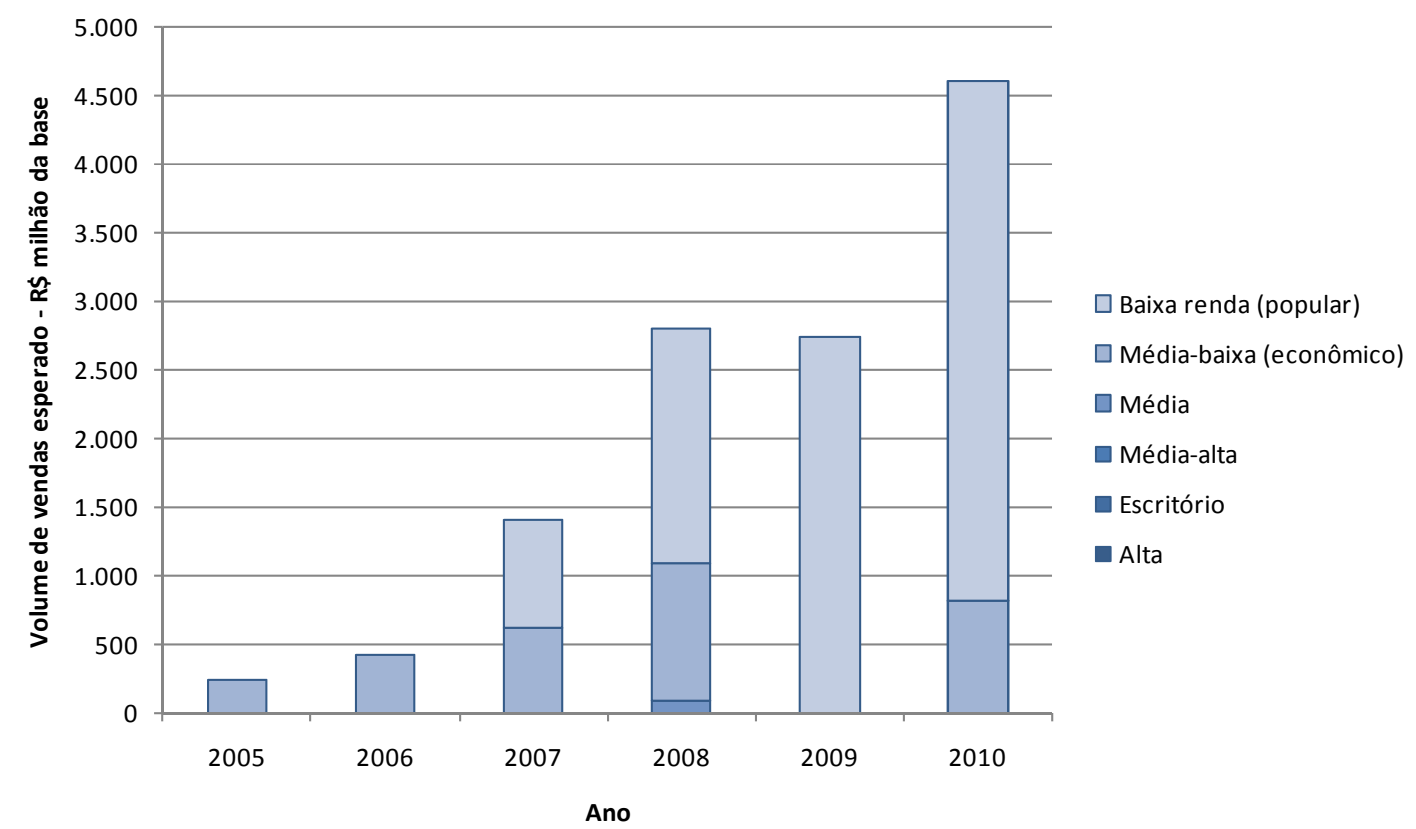

Gráfico 16 - Lançamentos por segmento de renda - MRV - em volume estimado de venda em R\$ milhão da base.

Fonte: elaboração do autor 


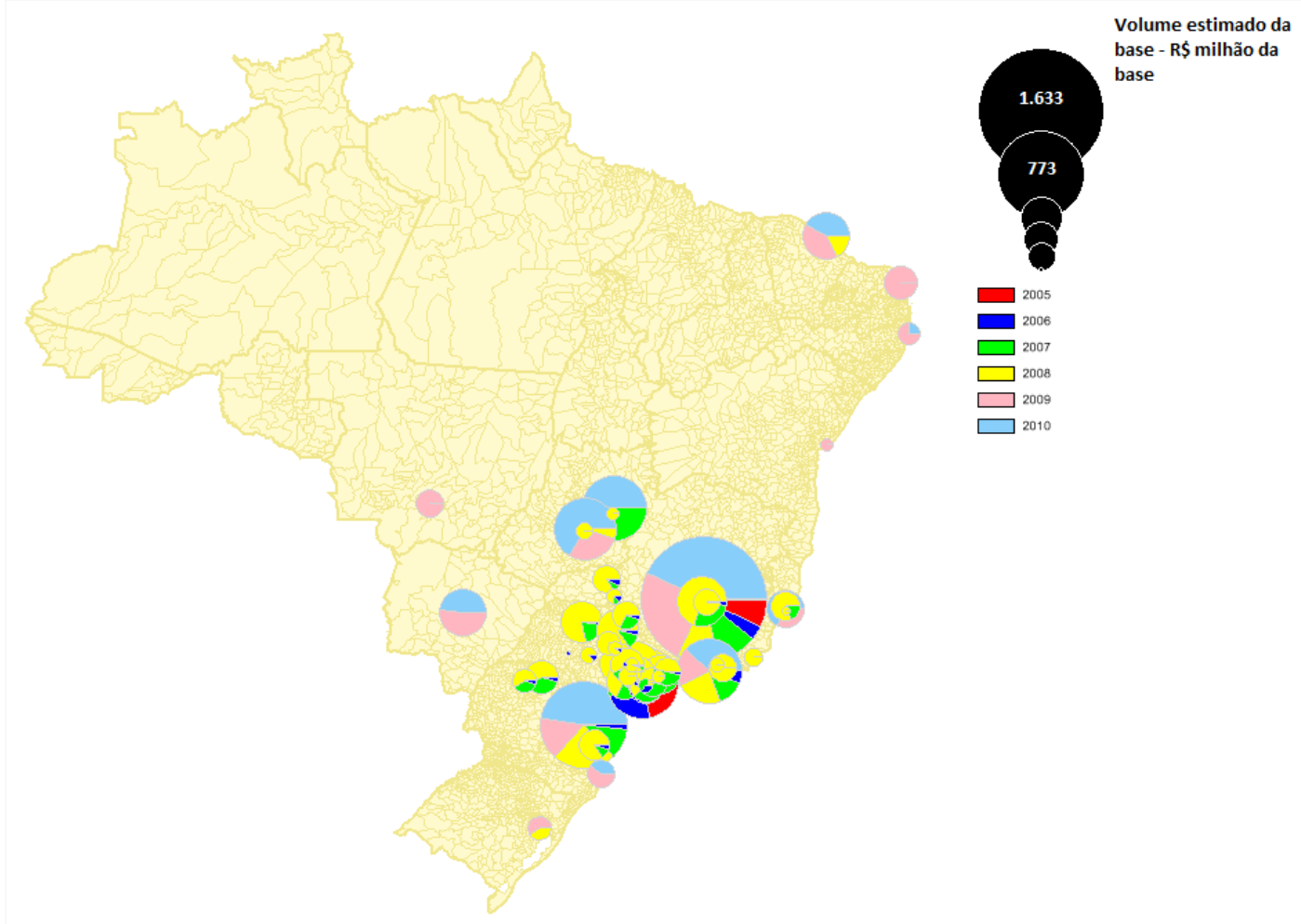

Figura 21 - Mapa de lançamentos da empresa MRV

Fonte: elaboração do autor 
Tabela 12 - Painel de indicadores da empresa MRV

\begin{tabular}{|c|c|c|c|c|c|c|c|c|c|c|c|c|c|c|c|c|c|c|c|c|c|}
\hline MRV & & Ano 20 & & & Ano 200 & & & Ano 20 & & & Ano 200 & & & Ano 20 & & & Ino 20 & & & do 200 & \\
\hline Atuação geográfica & & Estadua & & & Estadua & & & Nacion & & & Naciona & & & Naciona & & & Naciona & & & Naciona & \\
\hline Indice de diversificacão geográfica & Mun. & Reg. & Esta. & Mun. & Reg. & Esta. & Mun. & Reg. & Esta. & Mun. & Reg. & Esta. & Mun. & Reg. & Esta. & Mun. & Reg. & Esta. & Mun. & Reg. & Esta. \\
\hline & 0,50 & 0,50 & 0,50 & 0,85 & 0,68 & 0,49 & 0,93 & 0,88 & 0,67 & 0,96 & 0,92 & 0,67 & 0,70 & 0,70 & 0,70 & 0,66 & 0,66 & 0,66 & 0,84 & 0,81 & 0,67 \\
\hline Diversificação de produtos & & incentra & & & incentra & & & incentr: & & & oncentra & & & oncentr. & & & incentra & & & oncentra & \\
\hline Índice de diversificação de produto & & 0,00 & & & 0,00 & & & 0,50 & & & 0,50 & & & 0,00 & & & 0,29 & & & 0,37 & \\
\hline Segmento de renda & Médic & aixa (ec & mico) & Baix & renda $(\mathrm{p}$ & & Baix & enda $(p$ & & & renda $(\mathrm{p}$ & & & renda $(\mathrm{F}$ & & & renda $(\mathrm{p}$ & & & renda $(p$ & \\
\hline Estratégia de crescimento & & & & & & & & & & & רsão geo & & & & & & & & & & \\
\hline $\begin{array}{l}\text { Modelo de negócio predominante para } \\
\text { expansão de produtos }\end{array}$ & & & & & & & & & & & $n / a$ & & & & & & & & & & \\
\hline $\begin{array}{l}\text { Modelo de negócio predominante para } \\
\text { expansão geográfica }\end{array}$ & & & & & & & & & & Desen & olviment & prio & & & & & & & & & \\
\hline Indicadores operacionais e de deser & enho & & & & & & & & & & & & & & & & & & & & \\
\hline Receita - índice base 100 (ano 2005) & & 100 & & & 94 & & & 410 & & & 998 & & & 1.480 & & & 2.713 & & & $\mathrm{n} / \mathrm{a}$ & \\
\hline Lucro - índice base 100 (ano 2005) & & 100 & & & 55 & & & 181 & & & 1.064 & & & 1.581 & & & 2.682 & & & $\mathrm{n} / \mathrm{a}$ & \\
\hline Margem Líquida da empresa & & $21 \%$ & & & $12 \%$ & & & $9 \%$ & & & $23 \%$ & & & $23 \%$ & & & $21 \%$ & & & $n / a$ & \\
\hline Margem Líquida do mercado & & $16 \%$ & & & $15 \%$ & & & $13 \%$ & & & $15 \%$ & & & $15 \%$ & & & $15 \%$ & & & $n / a$ & \\
\hline $\begin{array}{l}\text { Retorno sobre o patrimônio Líquido da } \\
\text { empresa }\end{array}$ & & $33 \%$ & & & $15 \%$ & & & $6 \%$ & & & $17 \%$ & & & $19 \%$ & & & $23 \%$ & & & $n / a$ & \\
\hline $\begin{array}{l}\text { Retorno sobre o patrimônio Líquido do } \\
\text { mercado }\end{array}$ & & $23 \%$ & & & $14 \%$ & & & $11 \%$ & & & $14 \%$ & & & $16 \%$ & & & $18 \%$ & & & $n / a$ & \\
\hline Observações & $\begin{array}{l}\text { Concent } \\
\text { ros estad }\end{array}$ & $\begin{array}{l}\text { cão de } \\
\text { de São } \\
\text { Gerais }\end{array}$ & $\begin{array}{l}\text { amentos } \\
\text { o e Minas }\end{array}$ & \begin{tabular}{|} 
Expansẫ \\
estados do \\
e
\end{tabular} & $\begin{array}{l}\text { geográf } \\
\text { araná, } \\
\text { nta Cata }\end{array}$ & $\begin{array}{l}\text { para os } \\
\text { de Janeiro } \\
\text { ha }\end{array}$ & $\begin{array}{r}\text { Abert } \\
\text { BM\&F } \\
\text { geográff } \\
\text { Espírito Sa } \\
\text { Aquisiç̧ão }\end{array}$ & $\begin{array}{l}\text { ira de ca } \\
\text { ovespa. } \\
\text { a para } \\
\text { tho e Dis } \\
\text { tas cons } \\
\text { e Prime }\end{array}$ & $\begin{array}{l}\text { na } \\
\text { nsão } \\
\text { sdo do } \\
\text { Federal. } \\
\text { ras Blás }\end{array}$ & $\begin{array}{l}\text { Expansã } \\
\text { estados d }\end{array}$ & $\begin{array}{l}\text { geográf } \\
\text { Ceará, } \\
\text { ande do }\end{array}$ & $\begin{array}{l}\text { ara os } \\
\text { ia e Rio } \\
\text { ne Ro }\end{array}$ & $\begin{array}{l}\text { Expansã } \\
\text { estados d } \\
\text { Mato Gros } \\
\text { Grand }\end{array}$ & $\begin{array}{l}\text { geográf } \\
\text { Mato Gr } \\
\text { o e Pern } \\
\text { do Nort }\end{array}$ & $\begin{array}{l}\text { ara os } \\
\text { do Sul, } \\
\text { uco, Rio } \\
\text { hiia }\end{array}$ & $\begin{array}{r}\text { Crescit } \\
\text { mercados } \\
\text { per }\end{array}$ & $\begin{array}{l}\text { nto orie } \\
\text { esenvol } \\
\text { do } 2006\end{array}$ & $\begin{array}{l}\text { o aos } \\
\text { entreo } \\
9 .\end{array}$ & & & \\
\hline
\end{tabular}

Fonte: Elaboração do autor 


\subsubsection{RODOBENS}

A empresa Rodobens Negócios Imobiliários abriu capital na BM\&FBovespa em 2007. No mesmo ano, a empresa se declarava como uma companhia com atuação no segmento de baixa renda e com foco nas cidades do interior do país.

Entre 2006 e 2010 a empresa cresceu 14 vezes em volume de receita bruta, sendo a maior parte do crescimento ocorrido em novas regiões geográficas e nos segmentos de renda média-baixa e baixa.

Em termos de estratégia de crescimento, a companhia expandiu geografias, saindo de uma atuação de nível estadual para nacional, ao entrar em cidades de diversos estados do país, sempre com o foco no atuação no interior. Em termos de produtos, a empresa manteve sua concentração nos segmentos de menor renda.

Em termos de diversificação geográfica, em 2006 a empresa possuía elevada concentração no Estado de São Paulo, no entanto, diversificada entre diferentes municípios e mesorregiões. No ano posterior, iniciou sua estratégia de expansão geográfica, realizando lançamentos nos estados de Minas Gerais, Mato Grosso e Rio Grande do Sul, por meio de incorporação própria.

No ano de 2008, a Rodobens criou o segmento "Moradas", composto por unidades habitacionais de preço unitário entre $\mathrm{R} \$ 50$ mil a $\mathrm{R} \$ 75$ mil. A empresa já atuava neste segmento, no entanto, a segmentação permitiu maior foco na criação de soluções de produto específicas para o estrato de renda inferior.

Entre 2008 e 2010, a participação do segmento popular no portfólio de lançamentos da Rodobens passou de $42 \%$ para $82 \%$, enquanto sua diversificação geográfica, em termos de municípios, mesorregiões e estados atingiu seu maior valor.

Junto com a MRV, a empresa é representante das companhias com concentração de produtos na baixa renda e diversificação geográfica. 


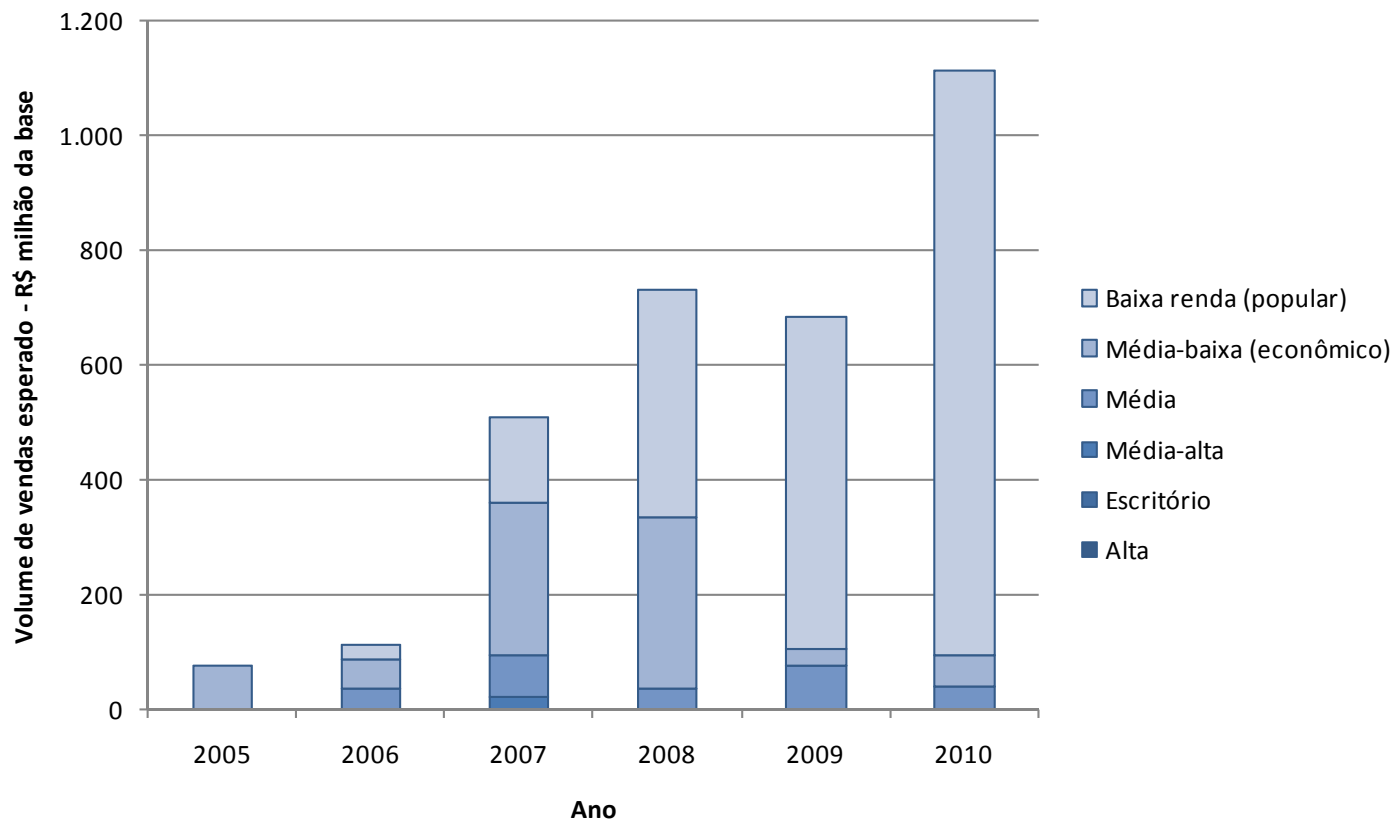

Gráfico 17 - Lançamentos por segmento de renda - Rodobens - em volume estimado de venda em R \$ milhão da base

Fonte: elaboração do autor

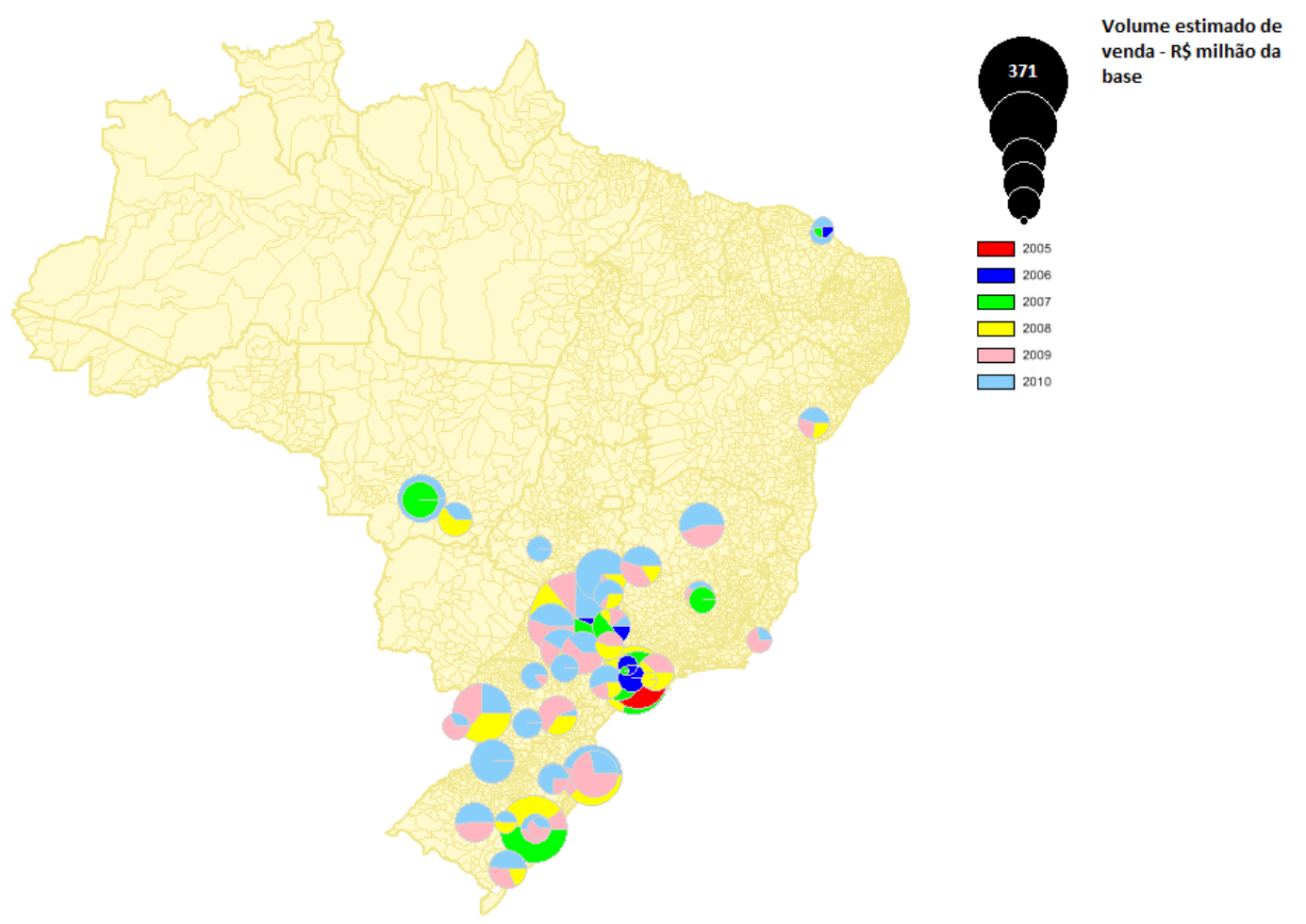

Figura 22 - Mapa de lançamentos da empresa Rodobens

Fonte: elaboração do autor 
Tabela 13 - Painel de indicadores da empresa Rodobens

\begin{tabular}{|c|c|c|c|c|c|c|c|c|c|c|c|c|c|c|c|c|c|c|c|c|c|}
\hline Rodobens & & Ano 200 & & & Ano 20 & & & Ano 200 & & & Ano 20 & & & Ano 200 & & & Ano 201 & & & do 2005 & \\
\hline Atuação geográfica & & Municip & & & Estadua & & & Nacional & & & Nacione & & & Naciona & & & Naciona & & & Naciona & \\
\hline Indice de diversificacão geográfica & Mun. & Reg. & Esta. & Mun. & Reg. & Esta. & Mun. & Reg. & Esta. & Mun. & Reg. & Esta. & Mun. & Reg. & Esta. & Mun. & Reg. & Esta. & Mun. & Reg. & Esta. \\
\hline Inaice de diversificaçao geogratica & 0,00 & 0,00 & 0,00 & 0,79 & 0,67 & 0,08 & 0,84 & 0,82 & 0,58 & 0,91 & 0,89 & 0,66 & 0,95 & 0,93 & 0,80 & 0,95 & 0,94 & 0,84 & 0,96 & 0,94 & 0,77 \\
\hline Diversificação de produtos & & oncentra & & & Dominar & & & ominan & & & oncentr & & & incentra & & & Concentra & & & oncentra & \\
\hline Índice de diversificação de produto & & 0,00 & & & 0,63 & & & 0,62 & & & 0,54 & & & 0,27 & & & 0,16 & & & 0,47 & \\
\hline Segmento de renda & Média & aixa (ec & mico) & Médi & baixa (ec & mico) & Média & aixa (eco & nico) & & renda $(\mathrm{f}$ & & Baix & renda $(\mathrm{p}$ & & & renda $(\mathrm{p}$ & & & renda $(p$ & \\
\hline Estratégia de crescimento & & & & & & & & & & & nsão gec & & & & & & & & & & \\
\hline $\begin{array}{l}\text { Modelo de negócio predominante para } \\
\text { expansão de produtos }\end{array}$ & & & & & & & & & & & $\mathrm{n} / \mathrm{a}$ & & & & & & & & & & \\
\hline $\begin{array}{l}\text { Modelo de negócio predominante para } \\
\text { expansão geográfica }\end{array}$ & & & & & & & & & & Desen & Iviment & Sprio & & & & & & & & & \\
\hline Indicadores operacionais e de desen & inho & & & & & & & & & & & & & & & & & & & & \\
\hline Receita - indice base 100 (ano 2005) & & 100 & & & 110 & & & 289 & & & 898 & & & 1.037 & & & 1.568 & & & $\mathrm{n} / \mathrm{a}$ & \\
\hline Lucro - índice base 100 (ano 2005) & & 100 & & & 96 & & & 1.275 & & & 3.365 & & & 1.128 & & & 2.912 & & & $\mathrm{n} / \mathrm{a}$ & \\
\hline Margem Líquida da empresa & & $5 \%$ & & & $5 \%$ & & & $24 \%$ & & & $21 \%$ & & & $6 \%$ & & & $10 \%$ & & & $\mathrm{n} / \mathrm{a}$ & \\
\hline Margem Líquida do mercado & & $16 \%$ & & & $15 \%$ & & & $13 \%$ & & & $15 \%$ & & & $15 \%$ & & & $15 \%$ & & & $\mathrm{n} / \mathrm{a}$ & \\
\hline $\begin{array}{l}\text { Retorno sobre o patrimônio Líquido da } \\
\text { empresa }\end{array}$ & & $8 \%$ & & & $5 \%$ & & & $10 \%$ & & & $15 \%$ & & & $5 \%$ & & & $11 \%$ & & & $\mathrm{n} / \mathrm{a}$ & \\
\hline $\begin{array}{l}\text { Retorno sobre o patrimônio Líquido do } \\
\text { mercado }\end{array}$ & & $23 \%$ & & & $14 \%$ & & & $11 \%$ & & & $14 \%$ & & & $16 \%$ & & & $18 \%$ & & & n/a & \\
\hline Observações & & & & & & & & $\begin{array}{l}\text { ura de cap } \\
\text { M\&FBoves }\end{array}$ & & $\begin{array}{r}\text { Parceria } \\
\text { Kokpla } \\
\text { est }\end{array}$ & $\begin{array}{l}\text { com o gr } \\
\text { para at } \\
\text { dos do }\end{array}$ & $\begin{array}{l}\text { Capae } \\
\text { io nos } \\
\text { ic }\end{array}$ & $\begin{array}{r}\text { Expansão } \\
\text { mercado } \\
\text { interior do } \\
\text { es } \\
\text { Aumento } \\
\text { segmento } \\
\text { program }\end{array}$ & $\begin{array}{l}\text { geográfica } \\
\text { e diversa } \\
\text { Estados } \\
\text { anta Cata } \\
\text { da conce } \\
\text { popular } \\
\text { ainha C } \\
\text { Vida. }\end{array}$ & $\begin{array}{c}\text { rada no } \\
\text { ades do } \\
\text { à Paulo } \\
\text { ẫo no } \\
\text { neio do } \\
\text { Minha }\end{array}$ & \begin{tabular}{|} 
Exp \\
Intensifica \\
interior \\
\\
Aumentc \\
segmentc \\
program
\end{tabular} & $\begin{array}{l}\text { ansão geog } \\
\text { ção de lan } \\
\text { dos estado } \\
\text { Brasil. } \\
\text { oda conce } \\
\text { popular } \\
\text { po Minha C } \\
\text { Vida. }\end{array}$ & $\begin{array}{l}\text { ca. } \\
\text { entos no } \\
\text { sul do } \\
\text { ção no } \\
\text { meio do } \\
\text { Minha }\end{array}$ & & & \\
\hline
\end{tabular}

Fonte: elaboração do autor 


\subsubsection{TECNISA}

A empresa Tecnisa S.A abriu capital na BM\&FBovespa no ano de 2007. Conforme índices apresentados no quadro 15, no ano anterior, a companhia possuía elevada exposição ao segmento de média-alta renda do mercado da cidade de São Paulo. Ao longo do período 2005-2010 a empresa diversificou suas atividades, ao realizar lançamentos em novas regiões geográficas e agregar ao seu portfólio empreendimentos destinados aos segmentos econômico e popular.

A estratégia de expansão geográfica teve início em 2007 por meio de lançamentos realizados nas cidades de Manaus e Goiânia, ambas por meio de parceria com as empresas locais -Tecnopar (AM) e Artefato Engenharia e FR Incorporadora (GO), respectivamente. Em 2008, além da região metropolitana de São Paulo e cidades lindeiras, a empresa realizou lançamentos nos municípios de Salvador e Fortaleza, ambos também por meio de parcerias com empresas locais - Petram e Terra Brasilis, respectivamente. Em 2009, a Tecnisa entrou no mercado de Curitiba, também por meio de parceria com empresa local - Monarco construtora.

Por fim, em 2010 a empresa deu continuidade às parcerias estabelecidas nos anos anteriores, realizando lançamentos nos municípios de Fortaleza e Brasília, além das cidades localizadas na região metropolitana de São Paulo e proximidades.

Cabe destacar que apesar da expansão para as novas regiões, a empresa não apresenta diversificação geográfica elevada, tal como outras empresas do setor. Ao longo do período, a Tecnisa pôde ser qualificada como uma empresa de elevada dispersão, pois apresenta empreendimentos distantes entre si, porém de concentração estadual, dada sua elevada concentração de lançamentos no estado de São Paulo.

Como estratégia de expansão de produtos, a empresa fez uso de recursos e próprios para desenvolver competências de produto e engenharia para o desenvolvimento de empreendimentos destinados aos segmentos de menor renda. Com o objetivo manter a marca Tecnisa, mas delimitar diferenciais de produtos com relação ao negócio original 
da companhia, a empresa definiu a marca TecnisaFlex para os produtos destinados aos segmentos econômico e popular.

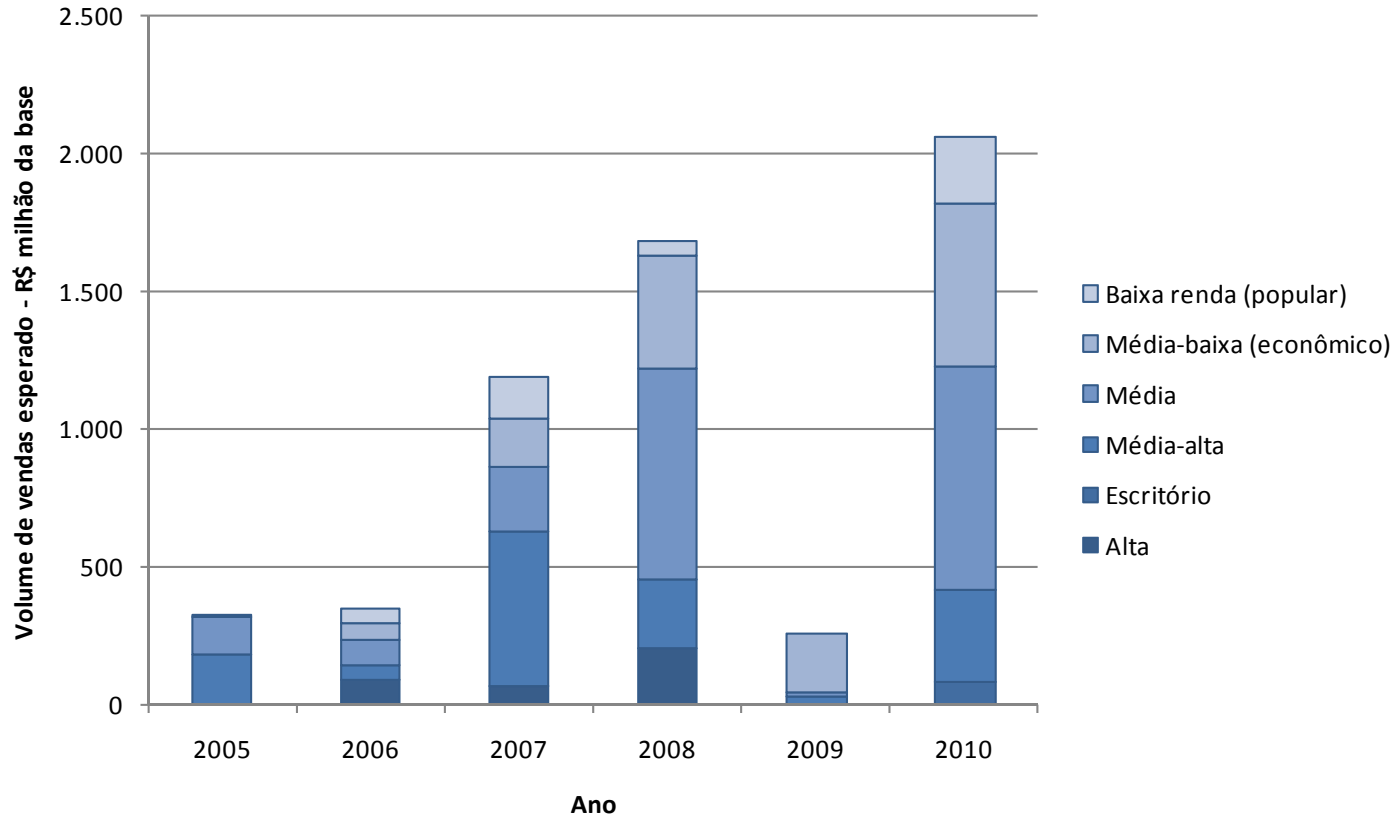

Gráfico 18 - Lançamentos por segmento de renda - Tecnisa - em volume estimado de venda em R \$ milhão da base.

Fonte: elaboração do autor

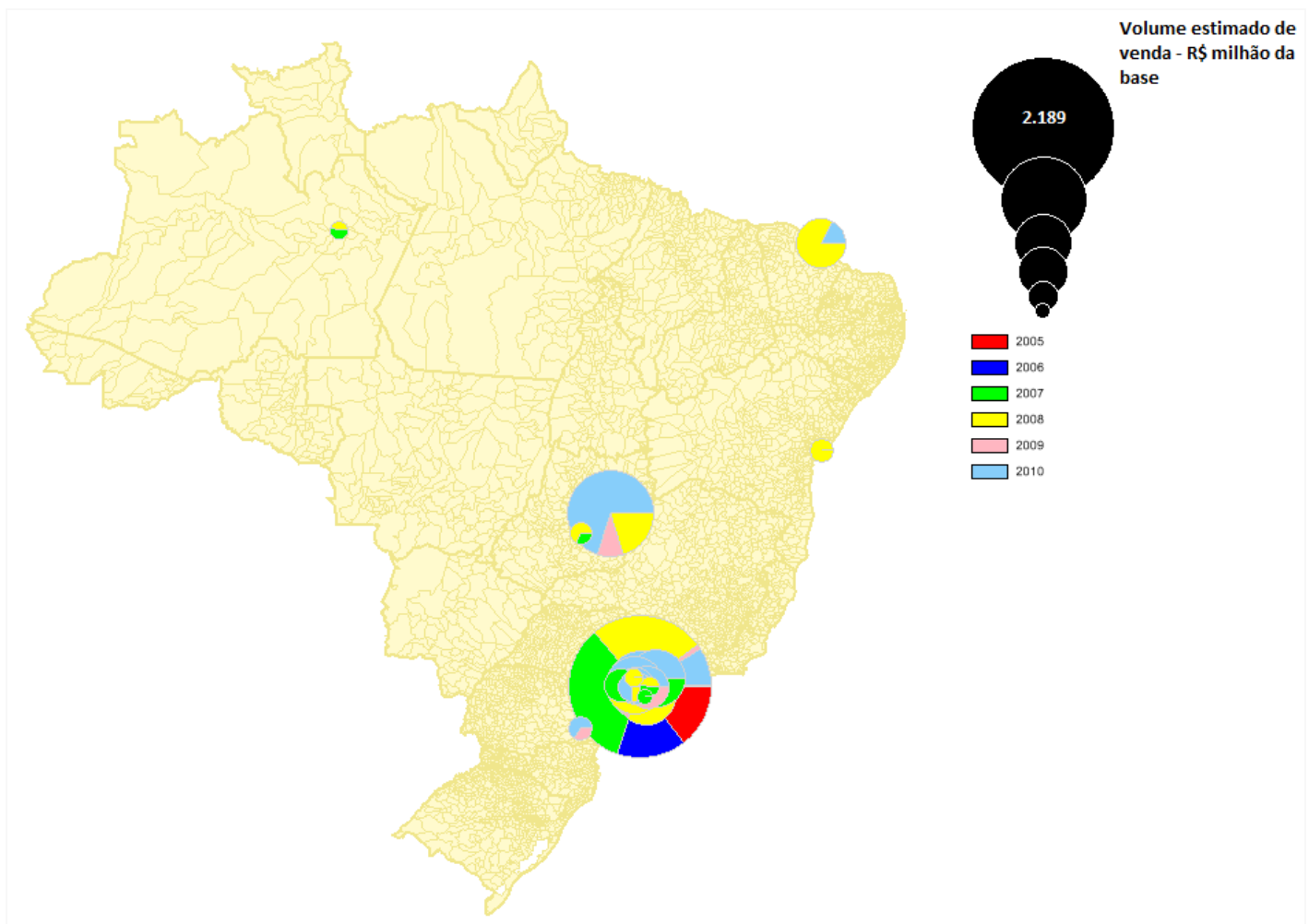

Figura 23 - Mapa de lançamentos da empresa Tecnisa Fonte: elaboração do autor 
Tabela 14 - Painel de indicadores da empresa Tecnisa

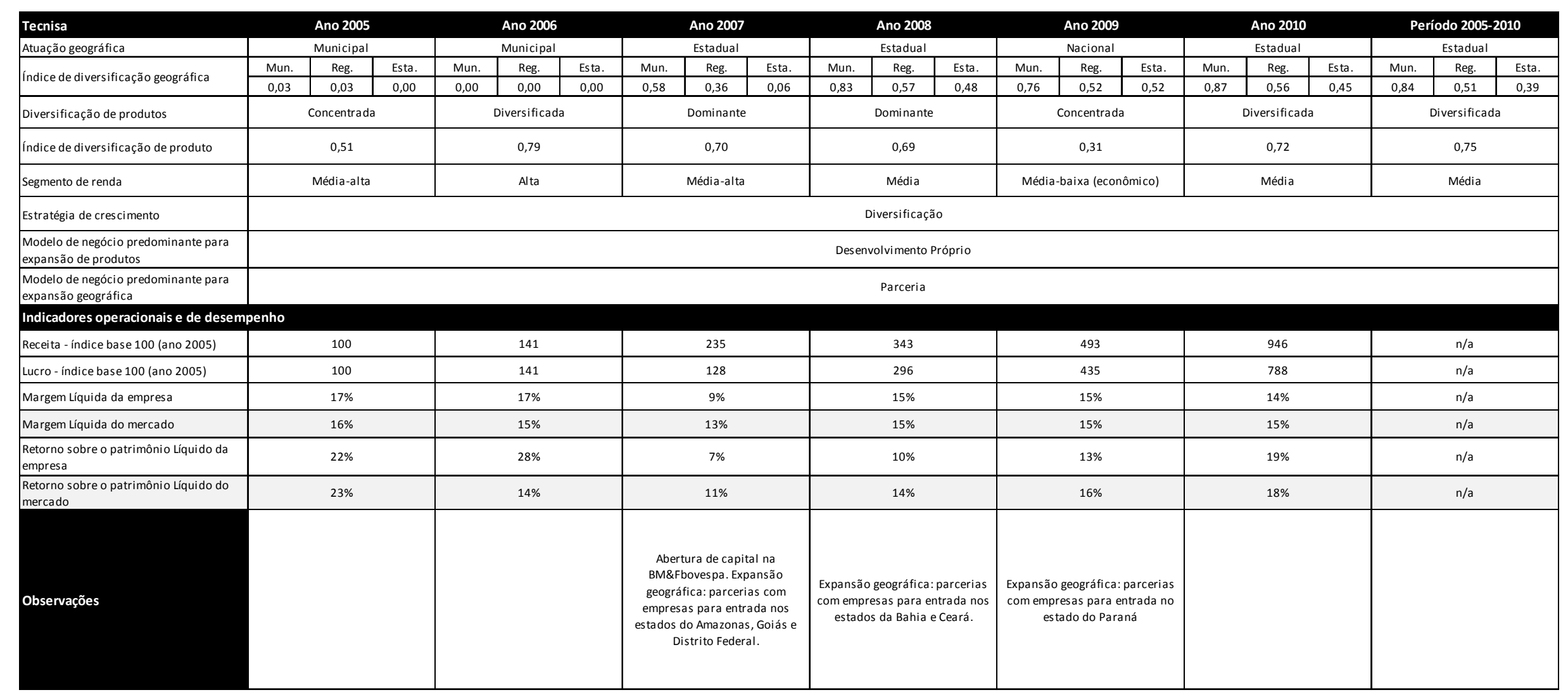

Fonte: elaboração do autor 


\subsubsection{AGRA, KLABIN SEGALL, ABYARA E AGRE}

A companhia Agra empreendimentos imobiliários S.A (AGRA) abriu capital na BM\&FBovespa em 2007. No ano anterior, a companhia já Figurava como uma empresa municipal, com atuação predominante no mercado da cidade de São Paulo.

A partir do ano 2007, a empresa deu início a sua estratégia de expansão geográfica. Para tanto, firmou parcerias com empresas dos estados da Bahia e Pará. Para entrada no segmento de baixa renda, a Agra adquiriu o controle da empresa Asacorp, especializada nos segmentos popular e econômico.

Em 2008 a empresa fundiu suas operações com as companhias KlabinSegall e Abyara, passando a formar o grupo Agre.

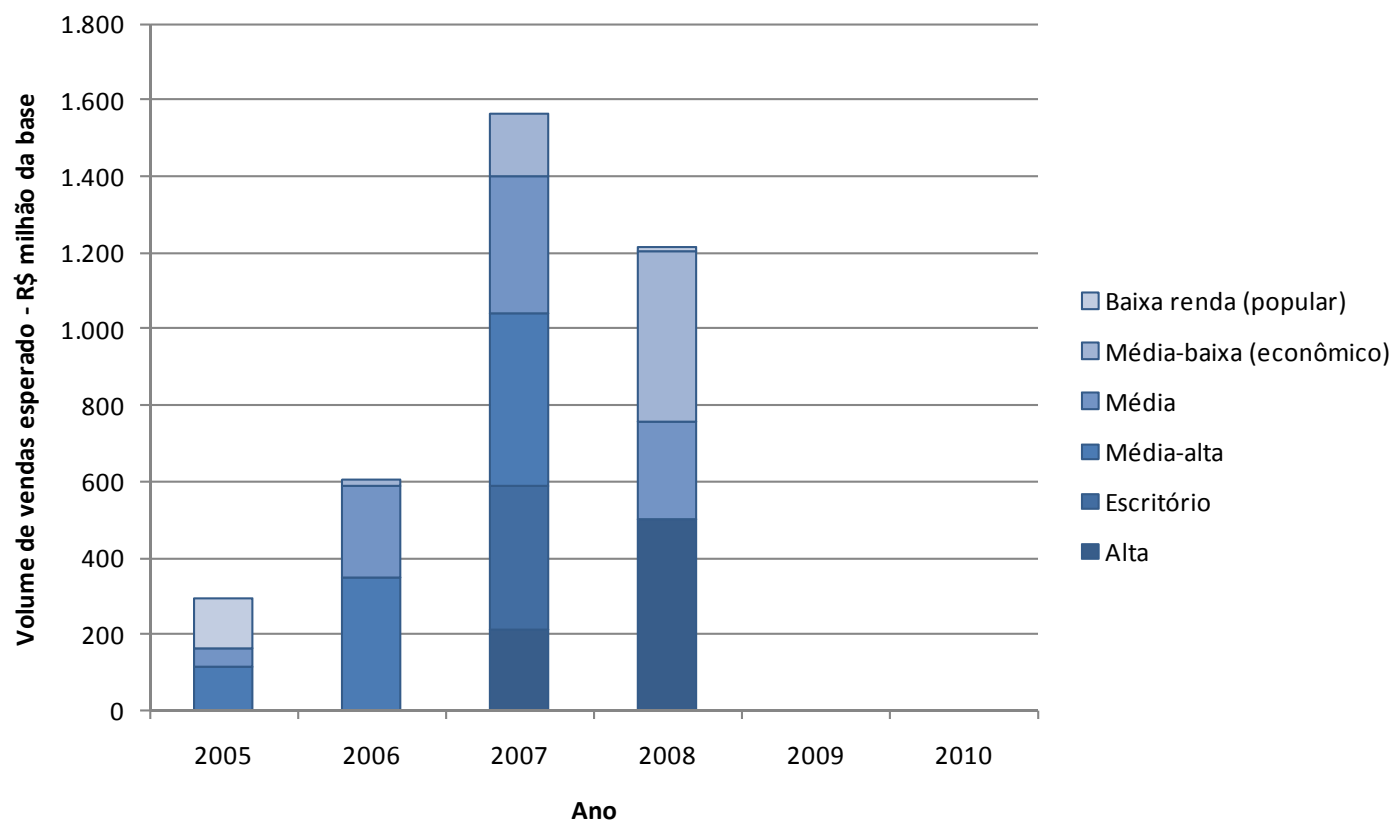

Gráfico 19 -Lançamentos por segmento de renda - Agra - em volume estimado de venda em $\mathrm{R}$ \$ milhão da base

A KLABIN SEGALL S/A (KlabinSegall) abriu capital na BMF Bovespa em 2006. Entre os anos 2005 e 2007, a empresa manteve sua concentração nos municípios de São Paulo e Rio de Janeiro, e nos segmentos de média-alta e média-baixa renda. A partir de 2008, iniciou sua estratégia de expansão geográfica, ao reabrir lançamentos nas regiões metropolitanas de Belo Horizonte, município de Anápolis e interior e 
interior de São Paulo. Como estratégia de expansão a empresa criou parceria com as construtoras locais COPEMA ( Ribeirão Preto) e HABITARE (Minas Gerais).

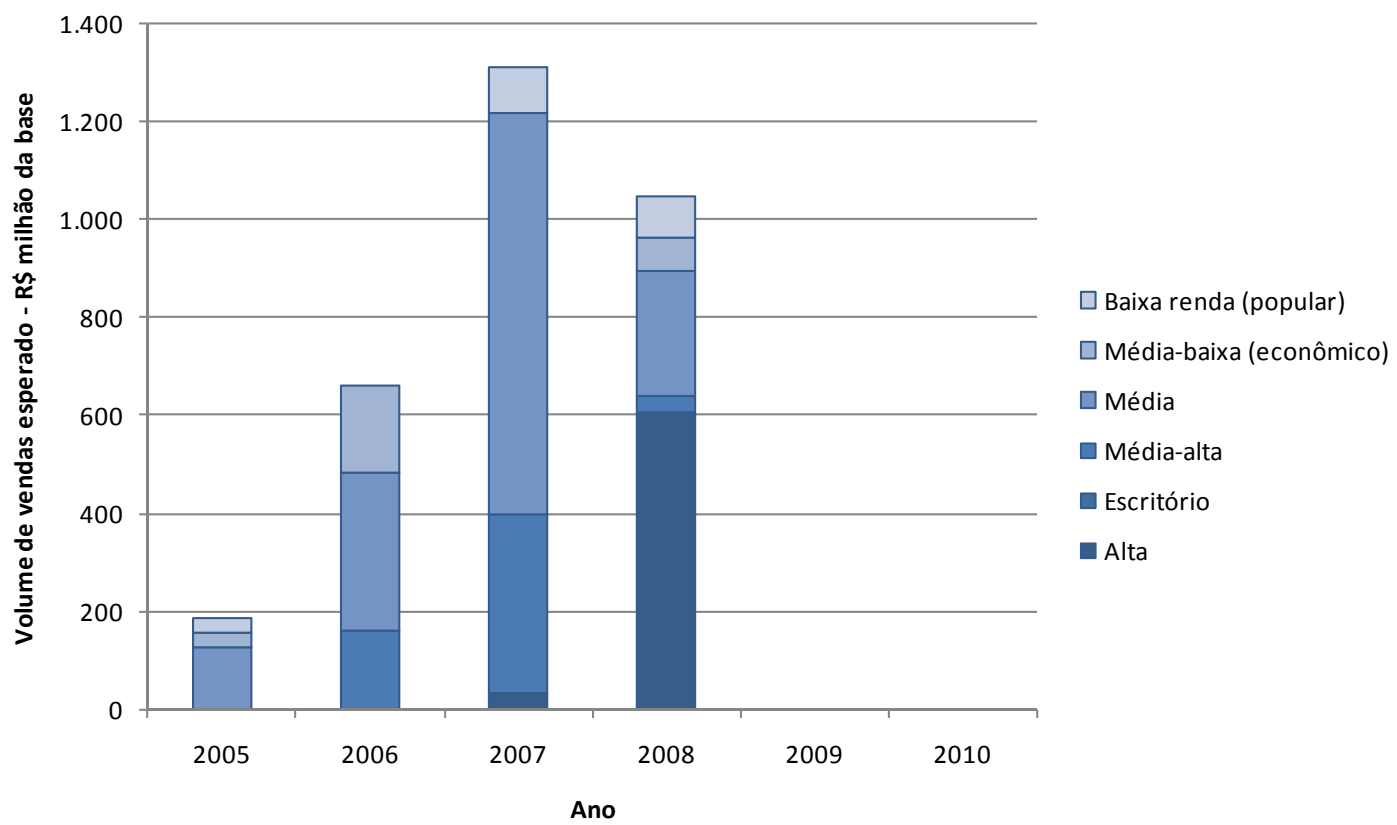

Gráfico 20 - Lançamentos por segmento de renda - KlabinSegall - em volume estimado de venda em $\mathrm{R}$ \$ milhão da base.

Fonte: elaboração do autor

A ABYARA Planejamento Imobiliário S/A (Abyara), tradicional empresa de consultoria e corretagem imobiliária, abriu capital no ano de 2006 com o objetivo de atrair na atividade de incorporação imobiliária.

A empresa traçou estratégia de co-incorporação de empreendimentos com tradicionais empresas do setor no segmento residencial da região metropolitana de São Paulo.

Apesar da concentração geográfica declarada, a empresa realizou lançamentos nas cidades de Salvador e Santos. No ano de 2008, a empresa realizou empreendimentos e oito estados do Brasil, destinados aos públicos de média-alta a baixa renda. 
A companhia Agre Empreendimentos (Amazon Group Real Estate) é resultado da fusão entre Abyara, KlabinSegall e Agra, como estratégia de entrada do grupo espanhol Veremonte Participações no mercado brasileiro em 2009.

A fusão criou uma das maiores empresas do Brasil em termos de patrimônio líquido. No entanto, não em termos econômicos e operacionais, em razão não somente das empresas incorporadas, mas também no desafio de unir empresas com portfólios de produtos e mercados distintos entre si.

Em 2010, a empresa foi adquirida pela PDG.

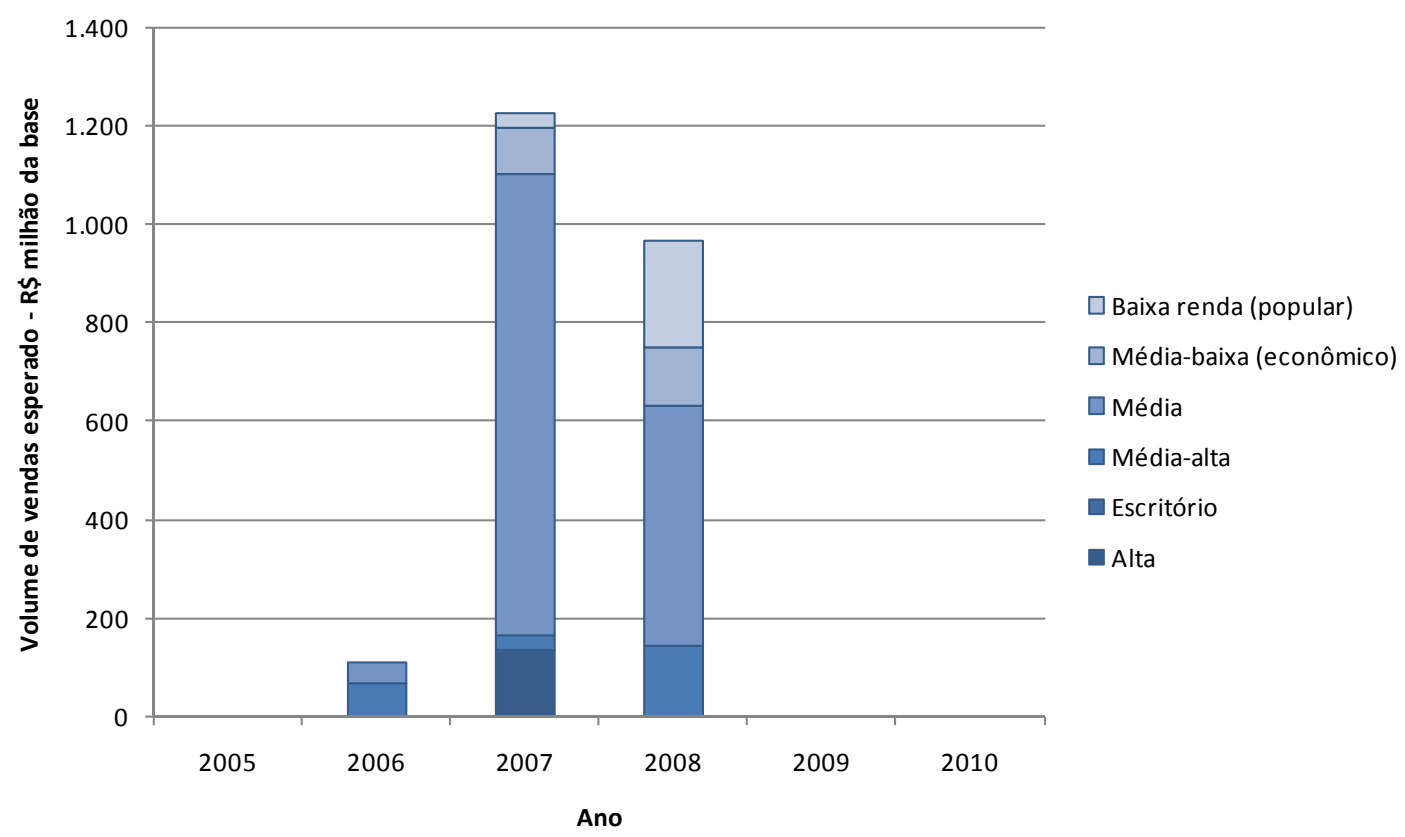

Gráfico 21 - Lançamentos por segmento de renda - Abyara - em volume estimado de venda em R\$ milhão da base

Fonte: elaboração do autor 
Volume estimado de venda - $\mathrm{R} \$$ milhão da base

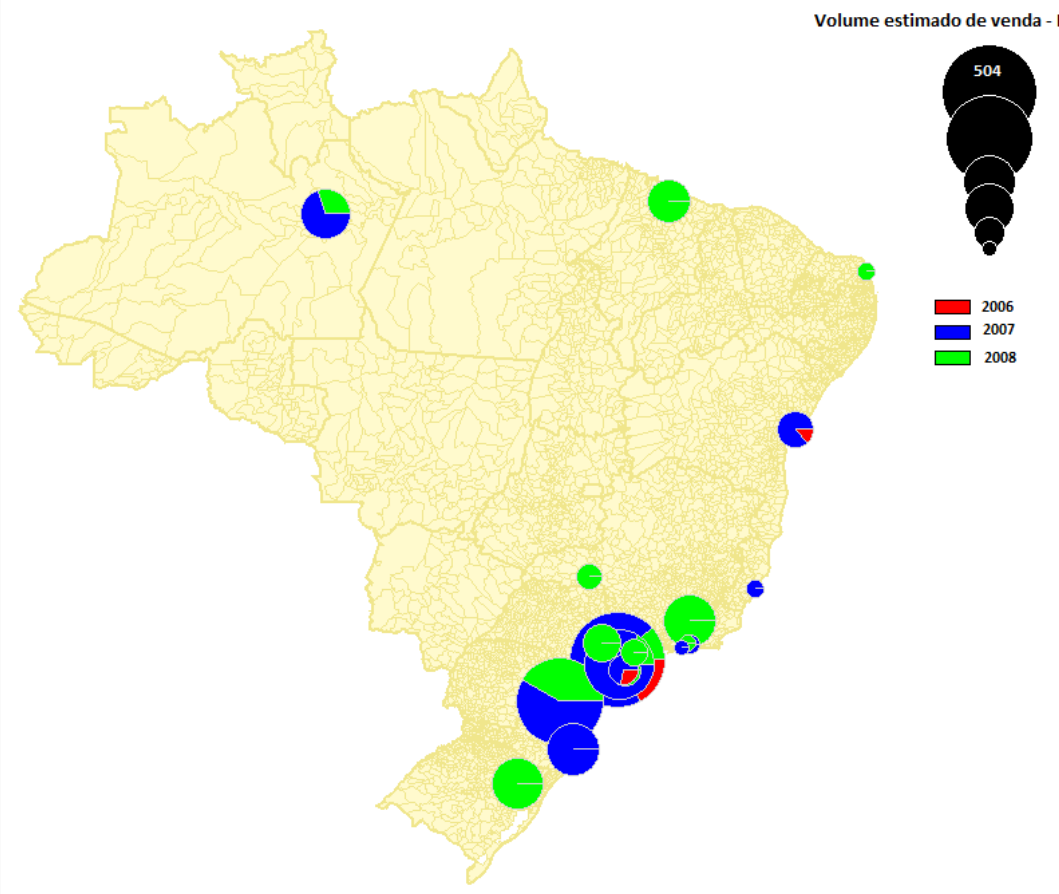

Figura 24 - Mapa de lançamentos da empresa Abyara

Fonte: elaboração do autor 


\subsubsection{JHSF}

A empresa JHSF é conhecida por sua atuação no segmento de alto padrão na cidade de São Paulo. A empresa abriu capital na BM\&FBovespa em 2007, e no ano anterior todos os lançamentos da companhia foram para destinados para o segmento de alta renda na cidade de São Paulo ${ }^{15}$.

A empresa possui um modelo de negócio distinto em relação às demais empresas do setor, ao realizar poucos empreendimentos em número, porém grandes em volume de área construída e receita.

Entre 2006 e 2010, a empresa saiu de uma companhia de atuação municipal e de concentração de produtos para uma empresa de atuação nacional e com um portfólio de produtos dominante, com lançamentos destinados ao segmento de alta renda e econômico. No entanto, a diversificação realizada pela empresa, apesar de representativas em termos de valor geral de vendas, parece ser pontual e não refletir uma estratégia de longo prazo, segundo informações dos resultados operacionais de 2010 (JHSF, 2010).

Em 2007, a empresa continuou com sua exposição única ao segmento de alto padrão, no entanto, iniciou movimento de expansão geográfica ao lançar a primeira fase do empreendimento Fazenda Boa Vista, localizado na cidade de Sorocaba.

Em 2008, continuou com lançamentos no segmento de alto padrão, no entanto, reduziu a exposição do portfólio ao destinar $50 \%$ do valor geral de vendas para o segmento comercial. Neste mesmo ano, a empresa expandiu sua atuação para a cidade de Salvador-BA, por meio de parceria com empreendedor local. No mesmo ano, a JHSF adquiriu a empresa Developer, especializada nos segmentos de baixa renda. No entanto, a aquisição não resultou em lançamentos e foi descontinuada da estratégia da companhia.

\footnotetext{
${ }^{15}$ A pesquisa não considerou os empreendimentos para renda, tais como hotéis, shopping center e equivalentes.
} 
Em 2009, por meio de uma parceria local, a empresa realizou um único lançamento, sendo este voltado ao segmento de média-baixa renda e localizado na cidade de Porto Velho-RO.

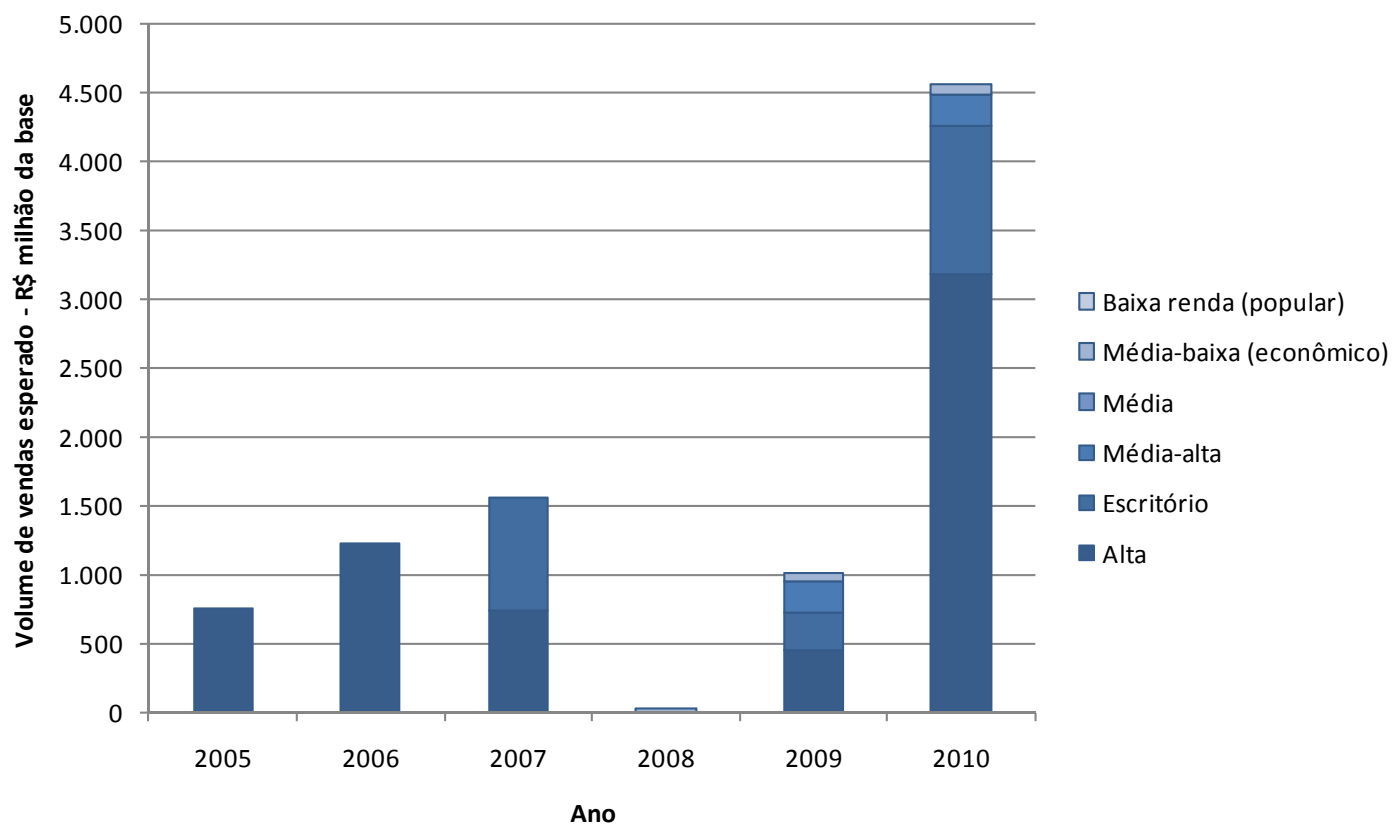

Gráfico 22 - Lançamentos por segmento de renda - JHSF- em volume estimado de venda em R\$ milhão da base

Fonte: elaboração do autor 


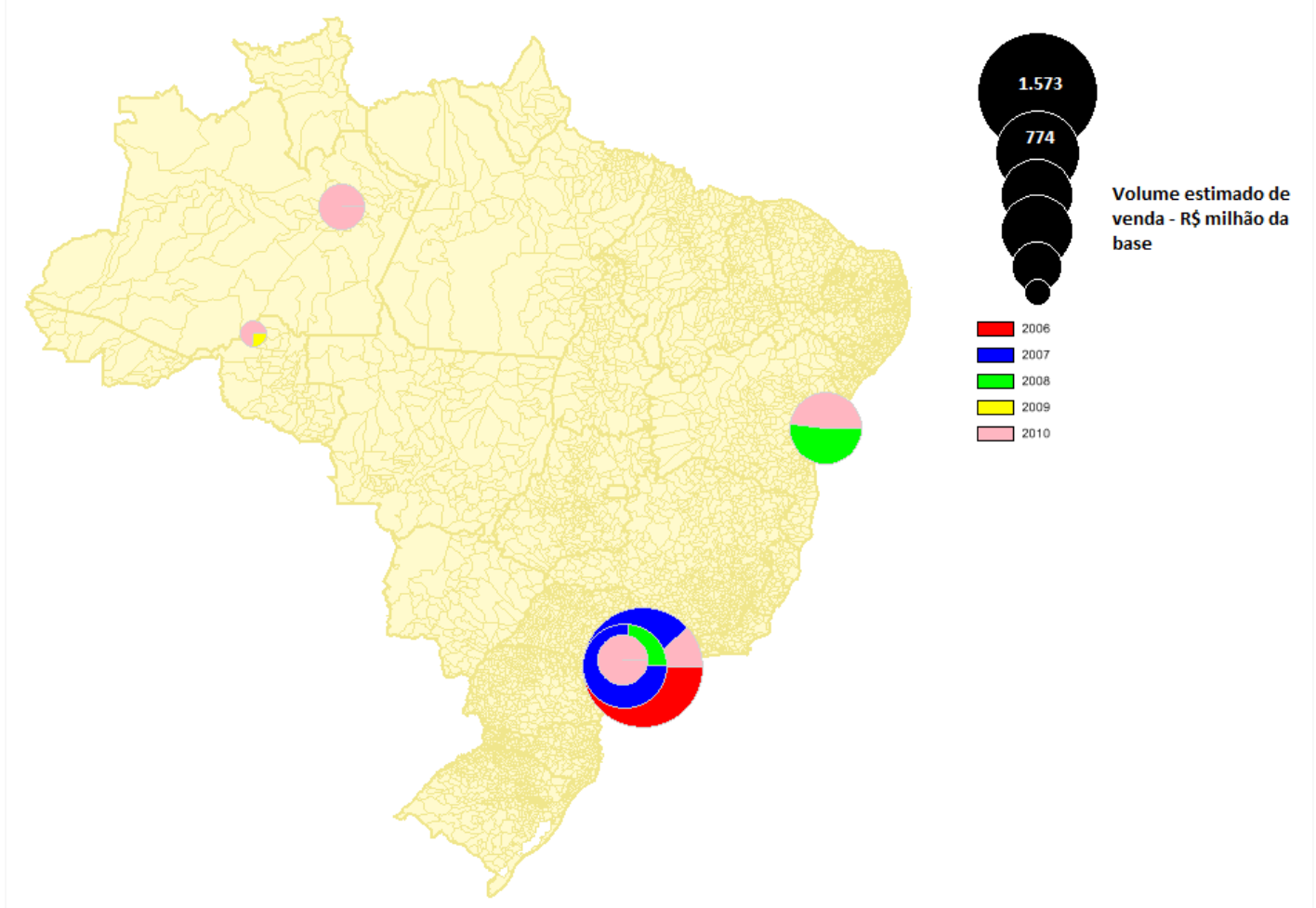

Figura 25 - Mapa de lançamentos da empresa JHSF

Fonte: elaboração do autor 
Tabela 15 - Painel de inicadores da empresa JHSF

\begin{tabular}{|c|c|c|c|c|c|c|c|c|c|c|c|c|c|c|c|c|c|c|c|c|c|}
\hline JHSF & & no 200 & & & Ano 20 & & & ino 20 & & & Ano 200 & & & Ano 20 & & & Ano 201 & & & do 200 & \\
\hline Atuaç̃oo geográfica & & $\mathrm{n} / \mathrm{a}$ & & & Municip & & & Estadu & & & Estadua & & & Municip & & & Naciona & & & Estadua & \\
\hline & Mun. & Reg. & Esta. & Mun. & Reg. & Esta. & Mun. & Reg. & Esta. & Mun. & Reg. & Esta. & Mun. & Reg. & Esta. & Mun. & Reg. & Esta. & Mun. & Reg. & Esta. \\
\hline IIndice de diversificação geográfica & $\mathrm{n} / \mathrm{a}$ & $\mathrm{n} / \mathrm{a}$ & $\mathrm{n} / \mathrm{a}$ & 0,00 & 0,00 & 0,00 & 0,50 & 0,50 & 0,00 & 0,47 & 0,47 & 0,31 & 0,00 & 0,00 & 0,00 & 0,77 & 0,77 & 0,67 & 0,61 & 0,59 & 0,32 \\
\hline Diversificação de produtos & & n/a & & & oncentr. & & & ncentr & & & incentra & & & oncentr. & & & Dominan & & & oncentra & \\
\hline Índice de diversificação de produto & & $\mathrm{n} / \mathrm{a}$ & & & 0,00 & & & 0,00 & & & 0,50 & & & 0,00 & & & 0,67 & & & 0,46 & \\
\hline Segmento de renda & & $n / a$ & & & Alta & & & Alta & & & Escritóri & & Média & aixa (ec & ico) & & Alta & & & Alta & \\
\hline Estratégia de crescimento & & & & & & & & & & & versifica & & & & & & & & & & \\
\hline $\begin{array}{l}\text { Modelo de negócio predominante para } \\
\text { expansão de produtos }\end{array}$ & & & & & & & & & & & Parceria & & & & & & & & & & \\
\hline $\begin{array}{l}\text { Modelo de negócio predominante para } \\
\text { expansão geográfica }\end{array}$ & & & & & & & & & & & Parceria & & & & & & & & & & \\
\hline Indicadores operacionais e de dese & nho & & & & & & & & & & & & & & & & & & & & \\
\hline Receita - indice base 100 (ano 2006) & & $\mathrm{n} / \mathrm{a}$ & & & 100 & & & 236 & & & 505 & & & 371 & & & 571 & & & $n / a$ & \\
\hline Lucro - índice base 100 (ano 2006) & & n/a & & & 100 & & & 101 & & & 286 & & & 295 & & & 404 & & & $\mathrm{n} / \mathrm{a}$ & \\
\hline Margem Líquida da empresa & & $n / a$ & & & $40 \%$ & & & $17 \%$ & & & $22 \%$ & & & $31 \%$ & & & $28 \%$ & & & $n / a$ & \\
\hline Margem Líquida do mercado & & $16 \%$ & & & $15 \%$ & & & $13 \%$ & & & $15 \%$ & & & $15 \%$ & & & $15 \%$ & & & $n / a$ & \\
\hline $\begin{array}{l}\text { Retorno sobre o patrimônio Liquido da } \\
\text { empresa }\end{array}$ & & n/a & & & $63 \%$ & & & $12 \%$ & & & $18 \%$ & & & $17 \%$ & & & $21 \%$ & & & $\mathrm{n} / \mathrm{a}$ & \\
\hline $\begin{array}{l}\text { Retorno sobre o patrimônio Líquido do } \\
\text { mercado }\end{array}$ & & $23 \%$ & & & $14 \%$ & & & $11 \%$ & & & $14 \%$ & & & $16 \%$ & & & $18 \%$ & & & $\mathrm{n} / \mathrm{a}$ & \\
\hline Observaçōes & & & & & & & & $\begin{array}{l}\text { a dec } \\
\text { \&fbov }\end{array}$ & & Expansão & ara o este & da Bahia & Expans & $\begin{array}{l}\text { o para o } \\
\text { Rondôn }\end{array}$ & do de & & & & & & \\
\hline
\end{tabular}

Fonte: elaboração do autor 


\subsubsection{HELBOR}

A Helbor abriu capital na BM\&FBovespa em 2007.

Segundo seu prospecto definitivo de oferta pública de ações (HELBOR, 2007), a empresa possuía concentração nas cidades de São Paulo e Mogi das Cruzes até o ano 2000. Desde então, a empresa deu início à sua estratégia de diversificação geográfica, estratégia intensificada após a abertura de capital, no entanto, insuficiente para uma diluição expressiva do portfólio de lançamentos, conforme a análise da evolução do portfólio de lançamentos.

Segundo o mesmo documento, a empresa possuía uma ampla estratégia pós-IPO, que envolvia a (1) expansão para o segmento de média-baixa renda, (2) o contínuo crescimento de lançamentos nas regiões e segmentos tradicionais de média a alta renda, na cidade de São Paulo, e (3) a expansão geográfica através do modelo de parcerias com players locais:

\footnotetext{
"Esta expansão deve priorizar cidades de médio e grande porte, com forte economia local. Para tanto, devemos continuar nosso modelo de parcerias com os players locais, em geral interessados na construção dos empreendimentos, a quem oferecemos participação no negócio de incorporação. Este nosso modelo de parcerias, nos permite atuar com rentabilidade em mercados de escala menor, classificados como menos atrativos por nossos concorrentes que atuem também na construção dos empreendimentos e, por isso, menos competitivos. Ao mesmo tempo, pretendemos intensificar nossa atuação nos diversos segmentos de renda no mercado da cidade de São Paulo, de forma a ampliar nossa participação que já é significativa - com atuação consolidada em mais de 20 bairros nas quatro regiões da Capital Paulista." (HELBOR, 2007. p. 56)
}

A análise da base de dados de lançamentos da empresa no período 2006-2009 demonstra que, apesar da expansão da Helbor para outras regiões geográficas, não houve alterações significativas na exposição da empresa aos mercados da Região Metropolitana de São Paulo, Vale do Paraíba Paulista e Centro Goiânio, que representavam 100\% do VGV dos lançamentos em 2006, e continuaram a representar 80\% do portfólio em 2009. 
Em 2007, a empresa a empresa entrou no mercado da cidade de Salvador e Florianópolis por meio de parcerias com empresas locais. O mesmo modelo de negócio foi aplicado nos anos seguintes para a expansão para os estados do Rio de Janeiro, Ceará, Mato Grosso, Mato Grosso do Sul e Minas Gerais

Quanto à atuação da empresa por segmentos de renda, a Helbor foi uma das únicas empresas a não expandir sua atuação para os segmentos de menor poder aquisitivo da sociedade, apesar da estratégia declarada no prospecto de sua primeira distribuição pública de ações ordinárias. Entre 2008 e 2009 a empresa diminuiu a participação do volume de lançamentos de empreendimentos do segmento de média-baixa renda, aumentando a participação dos segmentos de média renda e escritórios.

Pode-se concluir, portanto, que do ponto de vista da diversificação geográfica, apesar da entrada em novos mercados, a empresa não alterou significativamente sua exposição às regiões então exploradas pela empresa. Quanto à diversificação por segmento de renda, tampouco houve alterações significativas no indicador. Porém, houve ligeira diminuição na exposição ao segmento de média-baixa, e aumento no segmento de escritórios. 


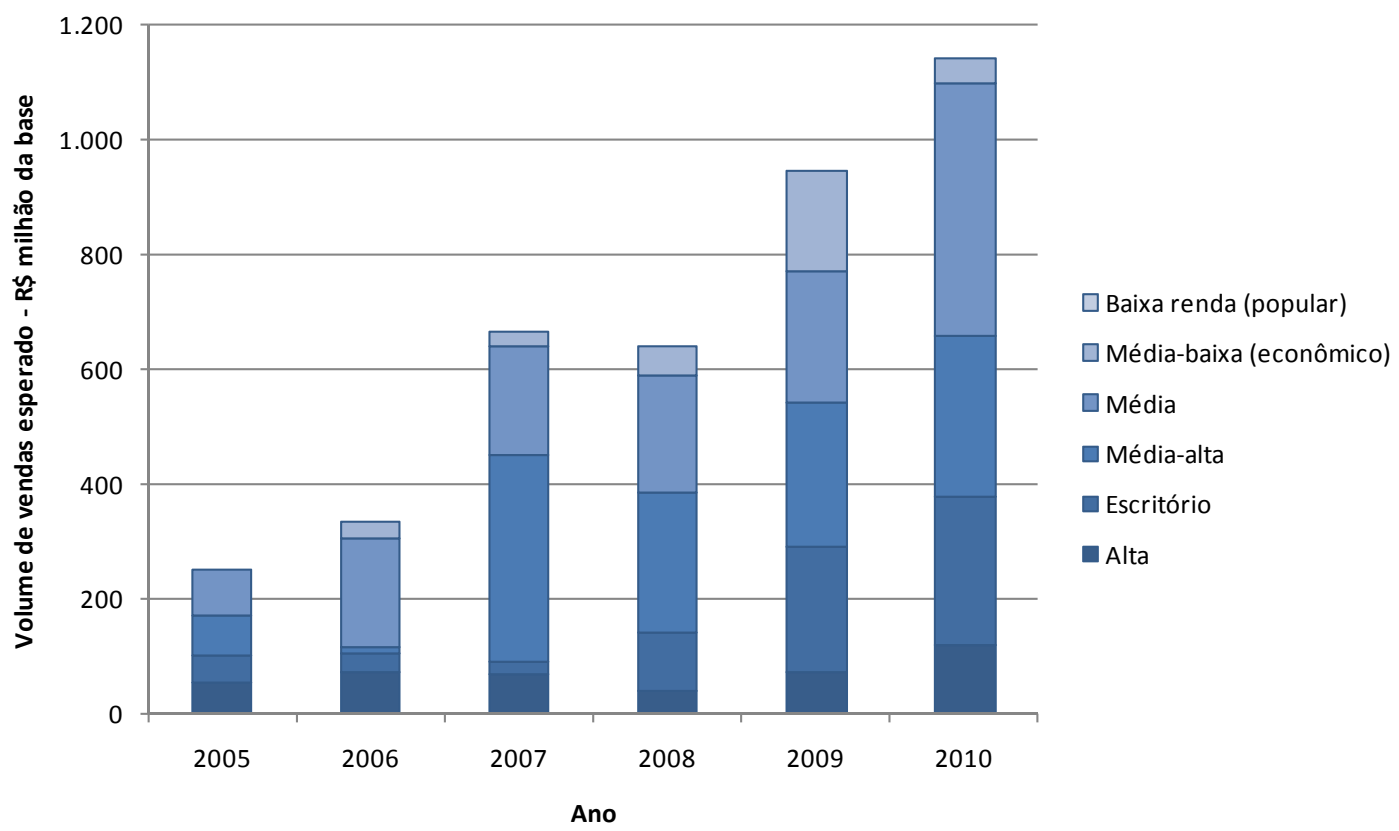

Gráfico 23 - Lançamentos por segmento de renda - Helbor - em volume estimado de venda em R \$ milhão da base

Fonte: elaboração do autor

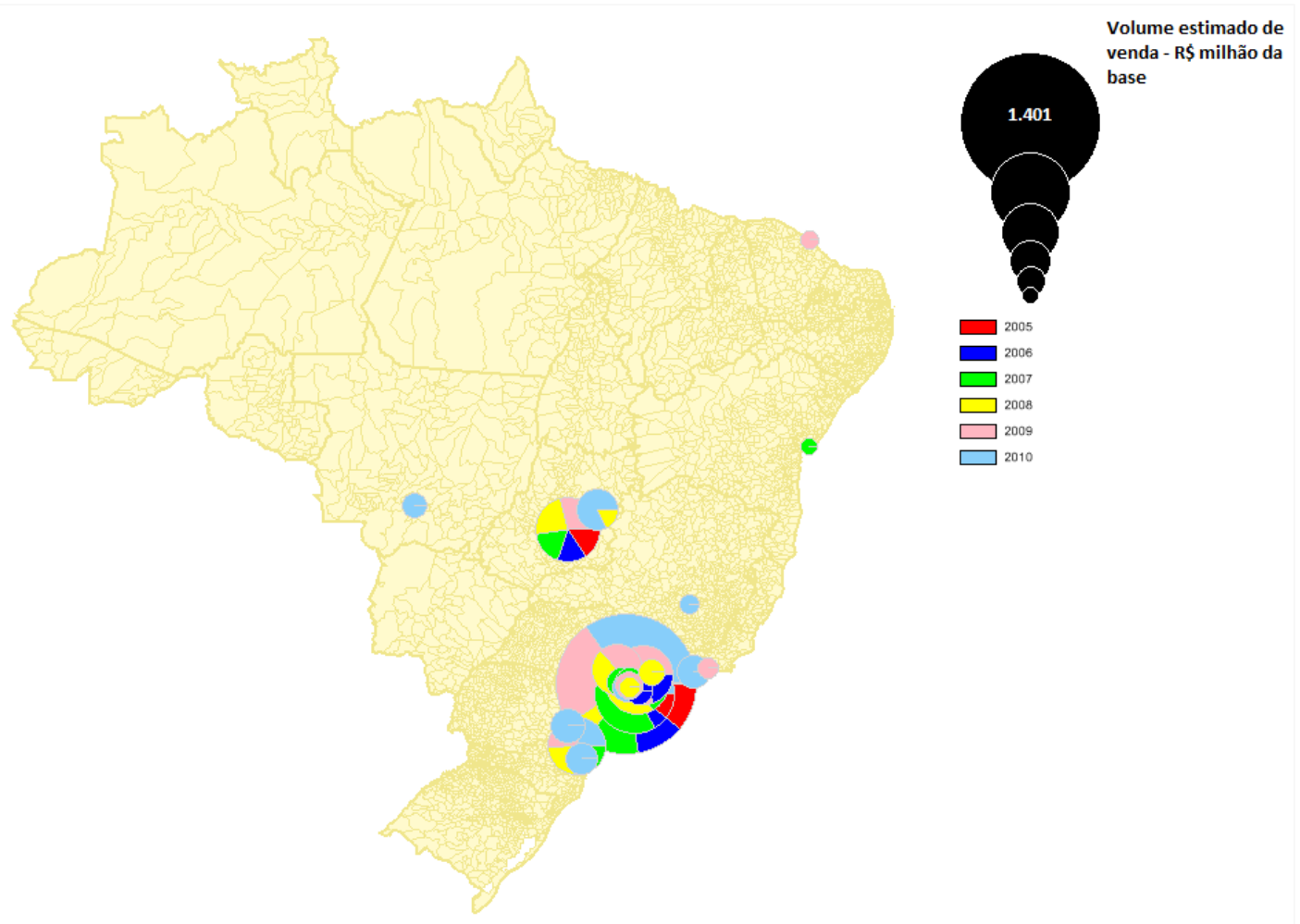

Figura 26 - Mapa de lançamentos da empresa Helbor

Fonte: elaboração do autor 
Tabela 16 - Painel de indicadores da empresa Helbor

\begin{tabular}{|c|c|c|c|c|c|c|c|c|c|c|c|c|c|c|c|c|c|c|c|c|c|}
\hline \multirow{2}{*}{\begin{tabular}{|l} 
Helbor \\
Atuação geográfica \\
\end{tabular}} & \multicolumn{3}{|c|}{ Ano 2005} & \multicolumn{3}{|c|}{ Ano 2006} & \multicolumn{3}{|c|}{ Ano 2007} & \multicolumn{3}{|c|}{ Ano 2008} & \multicolumn{3}{|c|}{ Ano 2009} & \multicolumn{3}{|c|}{ Ano 2010} & \multicolumn{3}{|c|}{ Período 2005-2010 } \\
\hline & \multicolumn{3}{|c|}{ Estadual } & \multicolumn{3}{|c|}{ Estadual } & \multicolumn{3}{|c|}{ Estadual } & \multirow{2}{*}{\multicolumn{3}{|c|}{ Estadual }} & \multicolumn{3}{|c|}{ Estadual } & \multicolumn{3}{|c|}{ Nacional } & \multicolumn{3}{|c|}{ Estadual } \\
\hline \multirow{2}{*}{ Índice de diversificação geográfica } & Mun. & Reg. & Esta. & Mun. & Reg. & Esta. & Mun. & Reg. & Esta. & Mun. & & Esta. & Mun. & Reg. & Esta. & Mun. & Reg. & Esta. & Mun. & Reg. & Esta. \\
\hline & 0,54 & 0,30 & 0,30 & 0,70 & 0,44 & 0,23 & 0,80 & 0,28 & 0,28 & 0,87 & 0,71 & 0,44 & 0,79 & 0,69 & 0,37 & 0,78 & 0,61 & 0,60 & 0,85 & 0,61 & 0,44 \\
\hline Diversificação de produtos & \multicolumn{3}{|c|}{ Diversificada } & \multicolumn{3}{|c|}{ Dominante } & \multicolumn{3}{|c|}{ Dominante } & \multicolumn{3}{|c|}{ Diversificada } & \multicolumn{3}{|c|}{ Diversificada } & \multicolumn{3}{|c|}{ Diversificada } & \multicolumn{3}{|c|}{ Diversificada } \\
\hline Índice de diversificação de produto & \multicolumn{3}{|c|}{0,74} & \multicolumn{3}{|c|}{0,61} & \multicolumn{3}{|c|}{0,62} & \multicolumn{3}{|c|}{0,72} & \multicolumn{3}{|c|}{0,78} & \multicolumn{3}{|c|}{0,73} & & 0,75 & \\
\hline Segmento de renda & & Média & & & Média & & & Média-al & & & Média-alt & & & Média-al & & & Média & & & Média & \\
\hline Estratégia de crescimento & & & & & & & & & & & versificas & & & & & & & & & & \\
\hline $\begin{array}{l}\text { Modelo de negócio predominante para } \\
\text { expansão de produtos }\end{array}$ & & & & & & & & & & Deser & olvimento & óprio & & & & & & & & & \\
\hline $\begin{array}{l}\text { Modelo de negócio predominante para } \\
\text { expansão geográfica }\end{array}$ & & & & & & & & & & & Parceria & & & & & & & & & & \\
\hline Indicadores operacionais e de deser & nho & & & & & & & & & & & & & & & & & & & & \\
\hline Receita - índice base 100 (ano 2005) & & 100 & & & 111 & & & 200 & & & 249 & & & 472 & & & 711 & & & $\mathrm{n} / \mathrm{a}$ & \\
\hline Lucro - índice base 100 (ano 2005) & & 100 & & & 97 & & & 19 & & & 273 & & & 443 & & & 1.026 & & & $\mathrm{n} / \mathrm{a}$ & \\
\hline Margem Líquida da empresa & & $13 \%$ & & & $11 \%$ & & & $1 \%$ & & & $14 \%$ & & & $12 \%$ & & & $18 \%$ & & & n/a & \\
\hline Margem Líquida do mercado & & $16 \%$ & & & $15 \%$ & & & $13 \%$ & & & $15 \%$ & & & $15 \%$ & & & $15 \%$ & & & $n / a$ & \\
\hline \begin{tabular}{|l|}
$\begin{array}{l}\text { Retorno sobre o patrimônio Líquido da } \\
\text { empresa }\end{array}$ \\
\end{tabular} & & $7 \%$ & & & $6 \%$ & & & $1 \%$ & & & $14 \%$ & & & $20 \%$ & & & $32 \%$ & & & $\mathrm{n} / \mathrm{a}$ & \\
\hline $\begin{array}{l}\text { Retorno sobre o patrimônio Líquido do } \\
\text { mercado }\end{array}$ & & $23 \%$ & & & $14 \%$ & & & $11 \%$ & & & $14 \%$ & & & $16 \%$ & & & $18 \%$ & & & $\mathrm{n} / \mathrm{a}$ & \\
\hline Observações & & & & & & & $\begin{array}{r}\text { Expans } \\
\text { estac }\end{array}$ & $\begin{array}{l}\text { ura de ca } \\
\text { M\&Fbove } \\
\text { ogeográfi } \\
\text { s da Bahi } \\
\text { Catarina }\end{array}$ & $\begin{array}{l}\text { ara os } \\
\text { ianta }\end{array}$ & Expansãa & para o Dis & o Federal & $\begin{array}{r}\text { Expansão } \\
\text { de }\end{array}$ & $\begin{array}{l}\text { ara os es } \\
\text { neiro e }\end{array}$ & os do Rio & $\begin{array}{l}\text { Expans } \\
\text { Minas }\end{array}$ & $\begin{array}{l}\text { para os } \\
\text { rais, Par } \\
\text { Grosso }\end{array}$ & $\begin{array}{l}\text { dos de } \\
\text { e Mato }\end{array}$ & & & \\
\hline
\end{tabular}

Fonte: elaboração do autor 


\subsubsection{EZTEC}

A empresa Eztec Empreendimentos e Participações S.A possuía em 2005 uma concentração no mercado de alta renda do município de São Paulo. Ao longo do período 2005-2010, a empresa ampliou a receita em sete vezes e, apesar da companhia ter expandido suas atividades para outros municípios da Região Metropolitana de São Paulo e Vale do Paraíba Paulista, manteve atuação predominante no capital do estado.

Em 2007 a empresa firmou parceria com as empresas Honduras, M\&M e Genea com o objetivo de realizar lançamentos no segmento de baixa renda. Ao contrário da maioria das empresas concorrentes, objeto de estudo da presente dissertação, a Eztec mantinha como estratégia o segmento de média-alta renda, porém com a intenção de realizar lançamentos nos segmentos de menor poder aquisitivo, por meio de parceiros, com o objetivo de laboratório, aprender e absorver as competências necessárias para o novo produto. (EZTEC, 2008).

Em 2008, em parceria com a empresa Genea, a Eztec entrou no mercado da cidade de Mogi das Cruzes com empreendimento destinado ao segmento econômico

Em 2009, a empresa ampliou a participação de lançamentos voltados para o segmento comercial e de alta renda; todos, no entanto, concentrados na Região Metropolitana de São Paulo.

No ano de 2010 a empresa manteve a sua estratégia de concentração no município de São Paulo e região lindeira, e ampliou sua participação no segmento econômico. Apesar das movimentações, a empresa manteve seu nível de diversificação geográfica como de atuação regional e portfólio de produtos concentrado.

As parcerias realizadas para a entrada no segmento de baixa renda e outros municípios do Estado de São Paulo, tento em vista o objetivo inicial de laboratório, não foram relevantes em volume estimado de venda em relação ao portólio total de lançamentos da empresa - aproximadamente $4 \%$ apenas -, configurando a estratégia de crescimento da empresas como penetração de mercado, com o objetivo de crescer 
predominantemente para produtos e mercados já operados pela empresa, sem o afastamento de suas competências principais.

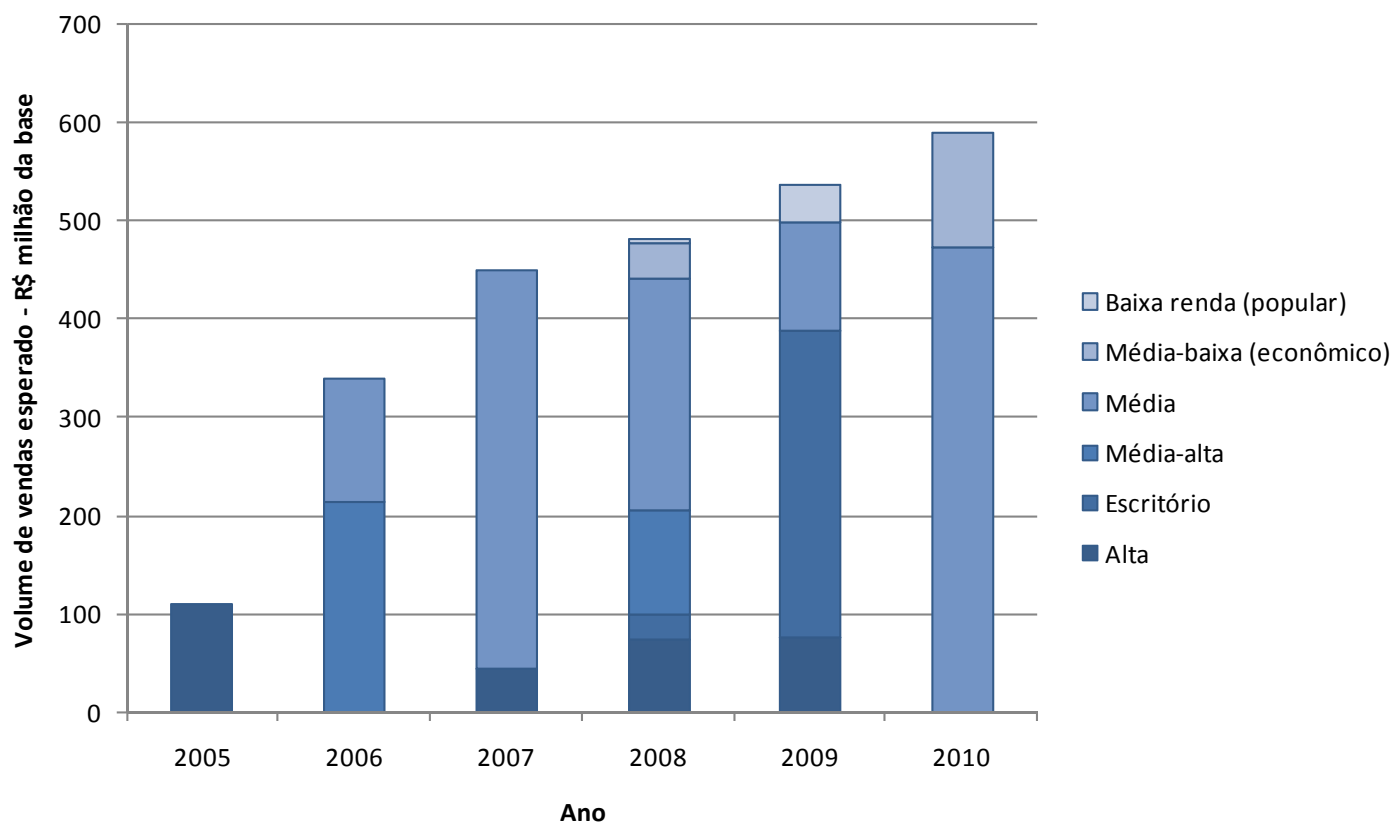

Gráfico 24 - Lançamentos por segmento de renda - Eztec- em volume estimado de venda em R\$ milhão da base

Fonte: elaboração do autor

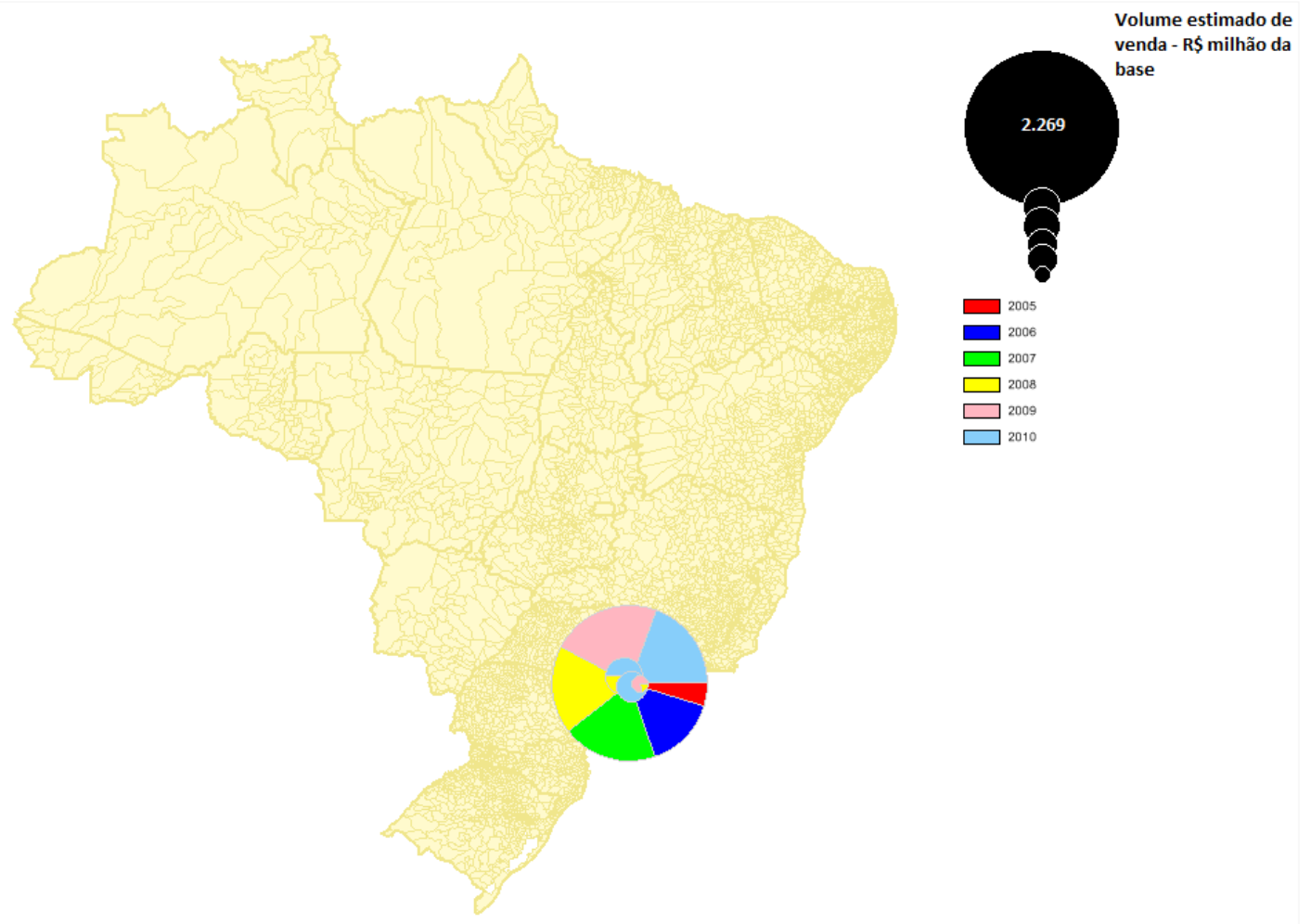

Figura 27 - Mapa de lançamentos da empresa Eztec

Fonte: elaboração do autor 
Tabela 17 - Painel de indicadores da empresa Eztec

\begin{tabular}{|c|c|c|c|c|c|c|c|c|c|c|c|c|c|c|c|c|c|c|c|c|c|}
\hline Eztec & & Ano $20 \mathrm{C}$ & & & Ano 2006 & & & Ano 200 & & & Ino 20 & & & Ano 200 & & & Ano 201 & & & odo 2005 & \\
\hline Atuação geográfica & & Municip & & & Municipal & & & Municipa & & & Municip & & & Municipa & & & Regiona & & & Municipa & \\
\hline líndice de diversificac̃̃ geográfic & Mun. & Reg. & Esta. & Mun. & Reg. & Esta. & Mun. & Reg. & Esta. & Mun. & Reg. & Esta. & Mun. & Reg. & Esta. & Mun. & Reg. & Esta. & Mun. & Reg. & Esta. \\
\hline IInaice de diversíficaçao geografica & 0,00 & 0,00 & 0,00 & 0,00 & 0,00 & 0,00 & 0,00 & 0,00 & 0,00 & 0,25 & 0,23 & 0,00 & 0,07 & 0,00 & 0,00 & 0,41 & 0,19 & 0,00 & 0,18 & 0,10 & 0,00 \\
\hline Diversificação de produtos & & oncentra & & & oncentrada & & & oncentra & & & Dominar & & & Dominant & & & incentra & & & Dominan & \\
\hline Índice de diversificação de produto & & 0,00 & & & 0,47 & & & 0,17 & & & 0,68 & & & 0,59 & & & 0,32 & & & 0,63 & \\
\hline Segmento de renda & & Alta & & & Média-alta & & & Média & & & Média & & & Escritóric & & & Média & & & Média & \\
\hline Estratégia de crescimento & & & & & & & & & & Pene & ação de & & & & & & & & & & \\
\hline $\begin{array}{l}\text { Modelo de negócio predominante para } \\
\text { expansão de produtos }\end{array}$ & & & & & & & & & & & Parceri & & & & & & & & & & \\
\hline $\begin{array}{l}\text { Modelo de negócio predominante para } \\
\text { expansão gegográfica }\end{array}$ & & & & & & & & & & & Parceri & & & & & & & & & & \\
\hline Indicadores operacionais e de dese & penho & & & & & & & & & & & & & & & & & & & & \\
\hline Receita - índice base 100 (ano 2005) & & 100 & & & 247 & & & 232 & & & 415 & & & 580 & & & 729 & & & $n / a$ & \\
\hline Lucro - índice base 100 (ano 2005) & & 100 & & & 20 & & & 139 & & & 309 & & & 493 & & & 742 & & & $n / a$ & \\
\hline Margem Líquida da empresa & & $38 \%$ & & & $3 \%$ & & & $23 \%$ & & & $28 \%$ & & & $32 \%$ & & & $39 \%$ & & & $n / a$ & \\
\hline Margem Líquida do mercado & & $16 \%$ & & & $15 \%$ & & & $13 \%$ & & & $15 \%$ & & & $15 \%$ & & & $15 \%$ & & & $\mathrm{n} / \mathrm{a}$ & \\
\hline $\begin{array}{l}\text { Retorno sobre o patrimônio Líquido da } \\
\text { empresa }\end{array}$ & & $32 \%$ & & & $4 \%$ & & & $11 \%$ & & & $14 \%$ & & & $18 \%$ & & & $24 \%$ & & & $\mathrm{n} / \mathrm{a}$ & \\
\hline $\begin{array}{l}\text { Retorno sobre o patrimônio Ĺquido do } \\
\text { mercado }\end{array}$ & & $23 \%$ & & & $14 \%$ & & & $11 \%$ & & & $14 \%$ & & & $16 \%$ & & & $18 \%$ & & & $n / a$ & \\
\hline Observações & $\begin{array}{l}\text { Atuação } \\
\text { mun }\end{array}$ & $\begin{array}{l}\text { média-ca } \\
\text { pio de S: }\end{array}$ & $\begin{array}{l}\text { renda no } \\
\text { aulo }\end{array}$ & $\begin{array}{r}\text { Manut } \\
\text { média-alt }\end{array}$ & $\begin{array}{l}\text { ç̧ão da atu } \\
\text { renda no m } \\
\text { São Paulo }\end{array}$ & $\begin{array}{l}\text { Eão na } \\
\text { nicíio de }\end{array}$ & $\mid \begin{array}{r}\text { Abe } \\
\text { Intensif } \\
\text { para a m } \\
\text { Anún } \\
\text { laboratór } \\
\text { de segme }\end{array}$ & $\begin{array}{l}\text { ura de car } \\
\text { M\&Fboves } \\
\text { ação de la } \\
\text { ia renda } \\
\text { e são Pau } \\
\text { de parce } \\
\text { ina atuaç } \\
\text { tos de ren } \\
\text { geográfica }\end{array}$ & $\begin{array}{l}\text { na } \\
\text { mentos } \\
\text { nunicípio } \\
\text { para } \\
\text { paratros } \\
\text { regiões }\end{array}$ & \begin{tabular}{|c} 
Realizaç \\
municipi \\
renda) \\
(média-b
\end{tabular} & $\begin{array}{l}\text { de lans } \\
\text { de Jund } \\
\text { Mogi da } \\
\text { ka renda } \\
\text { parceria }\end{array}$ & $\begin{array}{l}\text { tos nos } \\
\text { (média- } \\
\text { zes-SP } \\
\text { meio de }\end{array}$ & $\begin{array}{c}\text { Manute } \\
\text { mu } \\
\text { Metrop } \\
\text { Mogid }\end{array}$ & $\begin{array}{l}\text { ção da } \\
\text { cipios da } \\
\text { itana de } \\
\text { Cruzes e }\end{array}$ & $\begin{array}{l}\text { âo nos } \\
\text { ão } \\
\text { aulo - } \\
\text { Paulo }\end{array}$ & Lança & $\begin{array}{l}\text { to no } m \\
\text { to Andr }\end{array}$ & io de & & & \\
\hline
\end{tabular}

Fonte: Elaboração do autor 


\subsubsection{EVEN}

A Even construtora e incorporadora S.A abriu capital na BM\&FBovespa no ano de 2007.

Em 2005, possuía concentração de lançamentos no município de São Paulo e nos segmento de alta renda. Ao longo do período 2005-2010, diversificou seu portfólio de produtos, e expandiu sua atuação para outros municípios e estados do Brasil. Apesar da expansão, a empresa manteve concentração de lançamentos, em volume esperado de vendas, no estado de São Paulo. Segundo os índices e informações demonstradas levantadas nesta pesquisa, ao final do ano 2010 a empresa se classificou como uma companhia de atuação estadual e portfólio dominante de produtos.

Como estratégia de expansão geográfica, a empresa fez uso de parcerias com empreendedores locais. Para a entrada nos municípios do interior do estado de São Paulo e estado de Minas Gerais, a Even firmou parceria com a empresa Brisa. Para o mercado do Rio Grande do Sul, a empresa constituiu uma joint venture com a empresa local Melnick. Ainda que a Even não tenha realizado lançamentos no estados da região nordeste do país, foram identificadas e anunciadas parcerias com as empresas Capuche, Arc, Construtora Pernambuco e Magis.

Ao longo do período, a empresa também realizou lançamentos para os segmentos econômico e popular, cuja representatividade no portfólio de novos lançamentos, em volume esperado de vendas, saiu de $4 \%$ em 2005 para $40 \%$ em 2009. Para tanto, criou a marca Open e firmou parceria com a Inmax tecnologia e construção para o desenvolvimento conjunto de empreendimentos destinados ao público de média-baixa e baixa renda, com o objetivo de absorver tecnologia e processos específicos. 


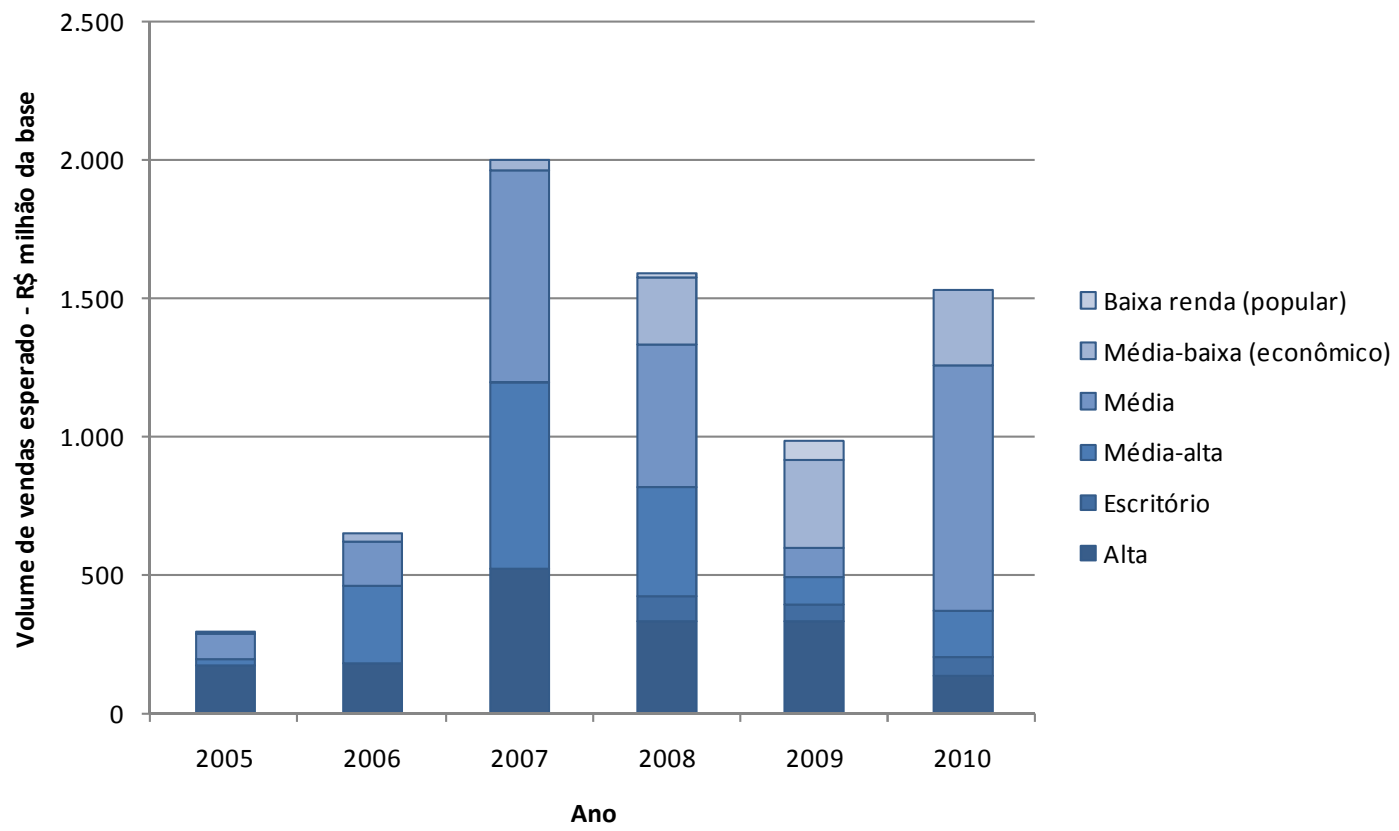

Gráfico 25 - Lançamentos por segmento de renda - Even- em volume estimado de venda em R \$ milhão da base

Fonte: elaboração do autor

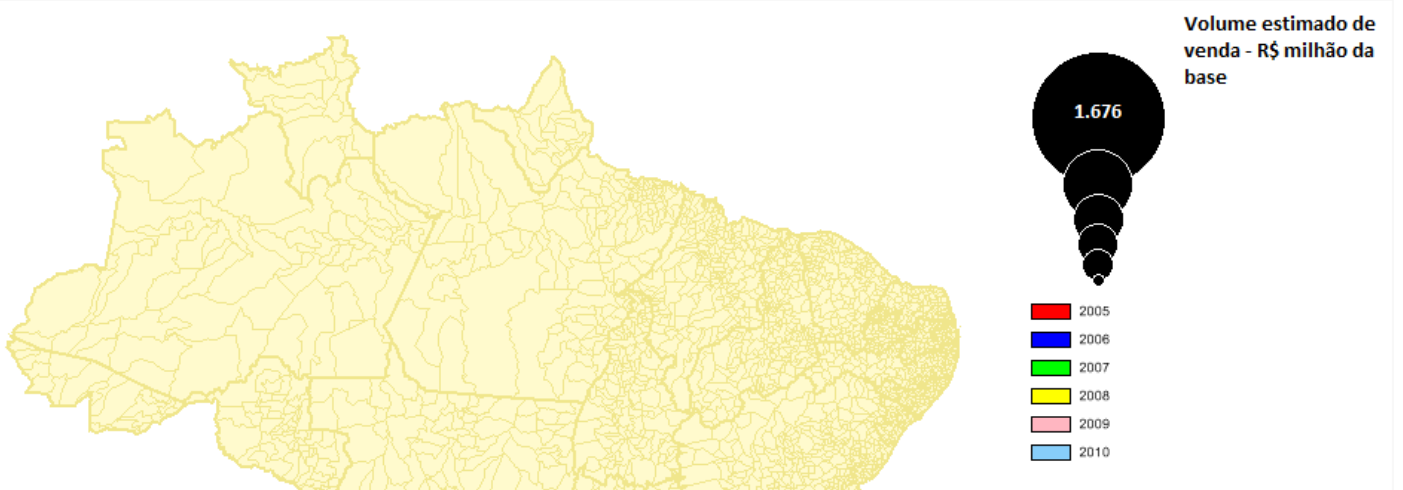

Figura 28 - Mapa de lançamentos da empresa Even

Fonte: elaboração do autor 
Tabela 18 - Painel de indicadores da emresa Even

\begin{tabular}{|c|c|c|c|c|c|c|c|c|c|c|c|c|c|c|c|c|c|c|c|c|c|}
\hline \multirow{4}{*}{\begin{tabular}{|l} 
Even \\
Atuação geográfica \\
Índice de diversificação geográfica \\
\end{tabular}} & \multirow{2}{*}{\multicolumn{3}{|c|}{$\begin{array}{l}\text { Ano } 2005 \\
\text { Municipal }\end{array}$}} & \multirow{2}{*}{\multicolumn{3}{|c|}{$\begin{array}{l}\text { Ano } 2006 \\
\text { Municipal }\end{array}$}} & \multicolumn{3}{|c|}{ Ano 2007} & \multicolumn{3}{|c|}{ Ano 2008} & \multicolumn{3}{|c|}{ Ano 2009} & \multicolumn{3}{|c|}{ Ano 2010} & \multicolumn{3}{|c|}{ Período 2005-2010 } \\
\hline & & & & & & & & Estadu & & & Estadua & & & Estadua & & & Estadual & & & Estadual & \\
\hline & Mun. & Reg. & Esta. & Mun. & Reg. & Esta. & Mun. & Reg. & Esta. & Mun. & Reg. & Esta. & Mun. & Reg. & Esta. & Mun. & Reg. & Esta. & Mun. & Reg. & Esta. \\
\hline & 0,00 & 0,00 & 0,00 & 0,07 & 0,07 & 0,07 & 0,63 & 0,57 & 0,37 & 0,37 & 0,30 & 0,22 & 0,40 & 0,32 & 0,27 & 0,46 & 0,36 & 0,33 & 0,46 & 0,39 & 0,29 \\
\hline Diversificação de produtos & \multicolumn{3}{|c|}{ Dominante } & \multicolumn{3}{|c|}{ Dominante } & \multicolumn{3}{|c|}{ Dominante } & \multicolumn{3}{|c|}{ Diversificada } & \multicolumn{3}{|c|}{ Diversificada } & \multicolumn{3}{|c|}{ Dominante } & \multicolumn{3}{|c|}{ Diversificada } \\
\hline Índice de diversificação de produto & \multicolumn{3}{|c|}{0,56} & \multicolumn{3}{|c|}{0,67} & \multicolumn{3}{|c|}{0,67} & \multicolumn{3}{|c|}{0,76} & \multicolumn{3}{|c|}{0,75} & \multicolumn{3}{|c|}{0,61} & \multicolumn{3}{|c|}{0,74} \\
\hline Segmento de renda & \multicolumn{3}{|c|}{ Alta } & \multicolumn{3}{|c|}{ Média-alta } & \multicolumn{3}{|c|}{ Média } & \multicolumn{3}{|c|}{ Média } & \multicolumn{3}{|c|}{ Alta } & \multicolumn{3}{|c|}{ Média } & \multicolumn{3}{|c|}{ Média } \\
\hline Estratégia de crescimento & & & & & & & & & & & versifice & & & & & & & & & & \\
\hline $\begin{array}{l}\text { Modelo de negócio predominante para } \\
\text { expansão de produtos }\end{array}$ & & & & & & & & & & Deser & Iviment & ́prio & & & & & & & & & \\
\hline $\begin{array}{l}\text { Modelo de negócio predominante para } \\
\text { expansão geográfica }\end{array}$ & & & & & & & & & & & Parceri & & & & & & & & & & \\
\hline Indicadores operacionais e de dese & nho & & & & & & & & & & & & & & & & & & & & \\
\hline Receita - indice base 100 (ano 2005) & & 100 & & & 273 & & & 560 & & & 1.049 & & & 1.480 & & & 2.478 & & & $\mathrm{n} / \mathrm{a}$ & \\
\hline Lucro - índice base 100 (ano 2005) & & 100 & & & 1.106 & & & 1.48 & & & 3.533 & & & 6.695 & & & 12.589 & & & $n / a$ & \\
\hline Margem Líquida da empresa & & $3 \%$ & & & $10 \%$ & & & $7 \%$ & & & $9 \%$ & & & $12 \%$ & & & $13 \%$ & & & $n / a$ & \\
\hline Margem Líquida do mercado & & $16 \%$ & & & $15 \%$ & & & $13 \%$ & & & $15 \%$ & & & $15 \%$ & & & $15 \%$ & & & $\mathrm{n} / \mathrm{a}$ & \\
\hline $\begin{array}{l}\text { Retorno sobre o patrimônio Líquido da } \\
\text { empresa }\end{array}$ & & $11 \%$ & & & $31 \%$ & & & $8 \%$ & & & $10 \%$ & & & $16 \%$ & & & $22 \%$ & & & $n / a$ & \\
\hline $\begin{array}{l}\text { Retorno sobre o patrimônio Líquido do } \\
\text { mercado }\end{array}$ & & $23 \%$ & & & $14 \%$ & & & $11 \%$ & & & $14 \%$ & & & $16 \%$ & & & $18 \%$ & & & $\mathrm{n} / \mathrm{a}$ & \\
\hline Observações & & & & & & & $\begin{array}{r}\text { Parceria } \\
\text { Meln }\end{array}$ & $\begin{array}{l}\text { ra dec } \\
\text { \& fbov } \\
\text { nas en } \\
\text { Capucl }\end{array}$ & $\begin{array}{l}\text { I na } \\
\text { as Brisa, } \\
\text { max. }\end{array}$ & $\begin{array}{l}\text { Expansãa a } \\
\text { com emp } \\
\text { Perna } \\
\text { entrad }\end{array}$ & $\begin{array}{l}\text { seográfi } \\
\text { sas ARC } \\
\text { puco en } \\
\text { na regiã }\end{array}$ & $\begin{array}{l}\text { arceria } \\
\text { istrutora } \\
\text { para } \\
\text { rdeste }\end{array}$ & & & & & & & & & \\
\hline
\end{tabular}

Fonte: elaboração do autor 


\subsubsection{ROSSI}

A empresa Rossi abriu capital na BM\&FBovespa em 2006. Tradicional incorporadora e construtora do setor, cresceu seu volume de receita em aproximadamente seis vezes, e ampliou sobremaneira o número de cidades com presença de lançamentos. No ano de 2005, a companhia realizou lançamentos em quatro cidades dos estados de São Paulo e Rio de Janeiro; ao final de 2010, foram quatorze estados do país e cinqüenta e uma cidades com lançamentos realizados. A participação dos lançamentos nos estados de São Paulo e Rio de Janeiro, juntos, saiu de 100\% para 53\% do portfólio em volume de vendas esperado.

Como estratégia de expansão geográfica, a empresa fez uso predominante de parcerias com empresas locais e abertura de escritórios regionais. No ano de 2006, foram identificados três contratos de parcerias para o desenvolvimento de empreendimentos imobiliários, com as empresas Alicerce (MG), Irmãos Thá (PR) e Melnick (RS). Em 2007, foram quatro parcerias: Metron e Cittá (ES), Costa Andrade (BA) e Diagonal (RN e CE). Em 2009, com o objetivo de ingressar nas regiões do Centro-Oeste e Norte brasileiros, a Rossi firmou mais duas parcerias com empresas locais: Marítima (DF) e Capital Construtora (AM e PA). Por fim, em 2010 os novos parceiros foram a GMS Construtora (MS) e Toctao (GO).

Segundo informações disponíveis no prospecto de abertura de capital da empresa (ROSSI, 2006), a estratégia de expandir por meio de parcerias com empreendedores locais tem como objetivo aproveitar o conhecimento que a empresa detém sobre o mercado e suas peculiaridades, desde os anseios da população local, o conhecimento de prestadores de serviços, trâmites legais para aprovação dos projetos, além do acesso imediato a banco de terrenos, cabendo à Rossi agregar valor aos empreendimentos por meio de sua experiência, estratégia de vendas, estruturação financeira e ganho de escala na aquisição de insumos.

Quando aos produtos, em 2005 a Rossi apresentava predominância de lançamentos para os segmentos de média e média-alta renda, apesar de ter realizado empreendimentos destinados ao segmento econômico e de escritórios. No ano 
seguinte, a empresa realizou lançamentos para o segmento de baixa renda (popular) e triplicou o volume os novos empreendimentos destinados ao segmento econômico, em volume esperado de vendas. A tendência foi mantida até o ano de 2010, quando a companhia atingiu um equilíbrio de produtos, destinando $50 \%$ do portfólio aos segmentos econômico e popular, e os outros $50 \%$ para os segmentos de renda média, média-alta, alta e escritórios.

Como estratégia de expansão para os segmentos de menor renda, a Rossi desenvolveu competências e recursos próprios, por meio da contratação de profissionais especializados, alocação de equipes e capacitação de profissionais, com o objetivo de desenvolver produtos e processos padronizados, em larga escala, específicos para os segmentos econômico e popular. A empresa já se beneficiava da experiência do segmento econômico decorrente de empreendimentos lançados ao longo da década de 1990, como o Plano 100, com 13.000 unidades residências e outras 9.000 entre outros projetos de bairro planejado e edifícios (ROSSI, 2009).

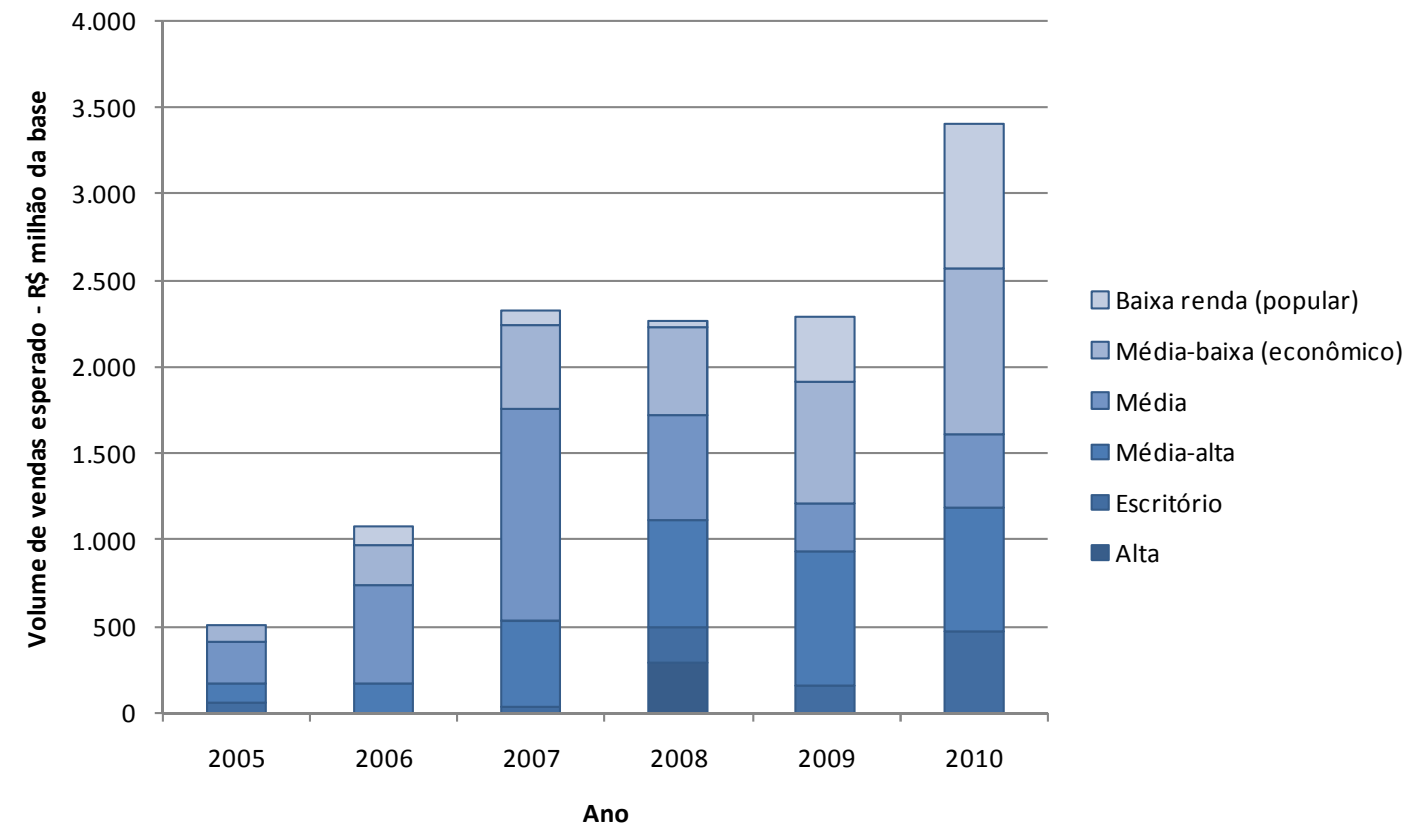

Gráfico 26 - Lançamentos por segmento de renda - Rossi - em volume estimado de venda em R\$ milhão da base

Fonte: elaboração do autor 


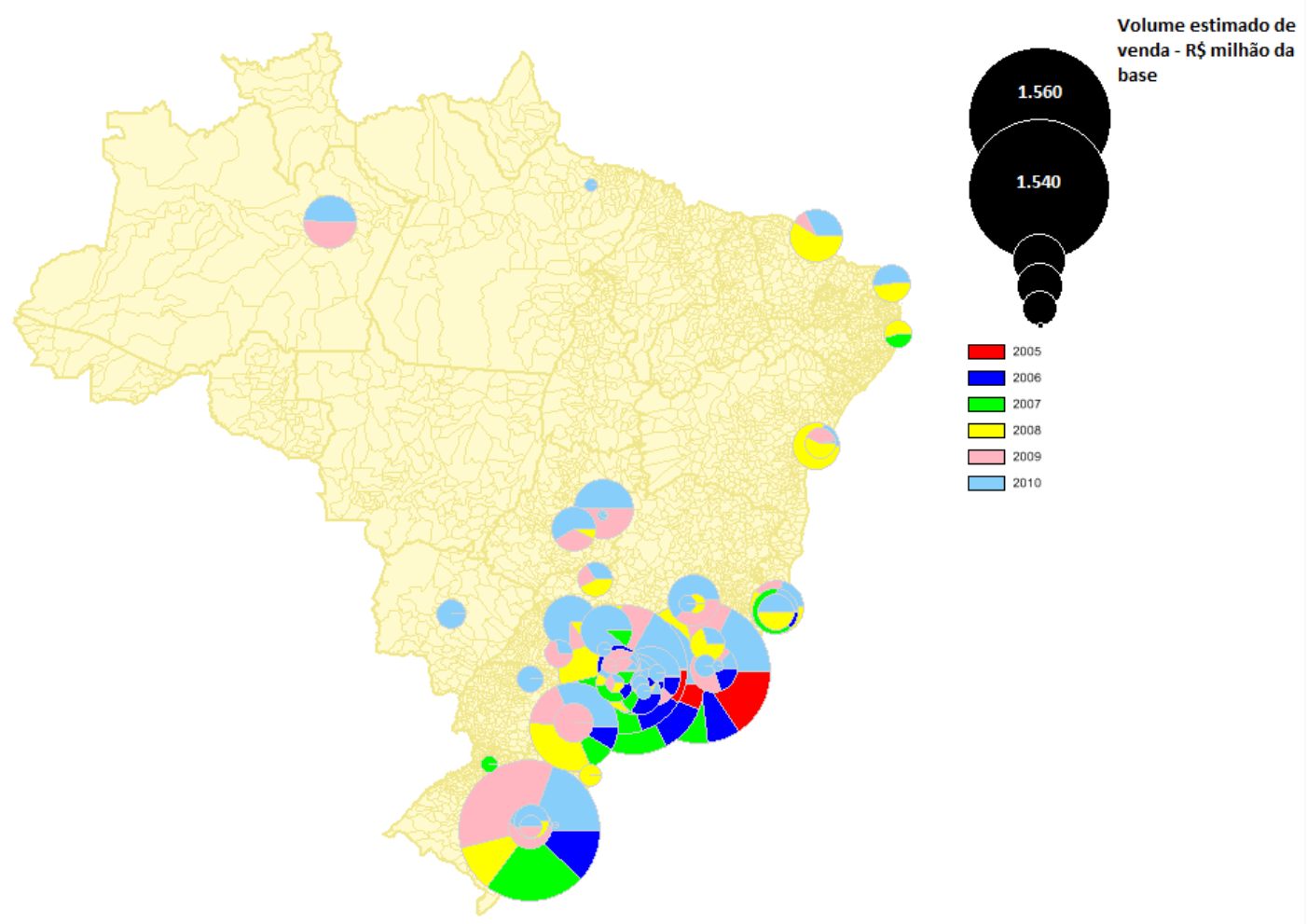

Figura 29 - Mapa de lançamentos da empresa Rossi Fonte: elaboração do autor 
Tabela 19 - Painel de Indicadores da empresa Rossi

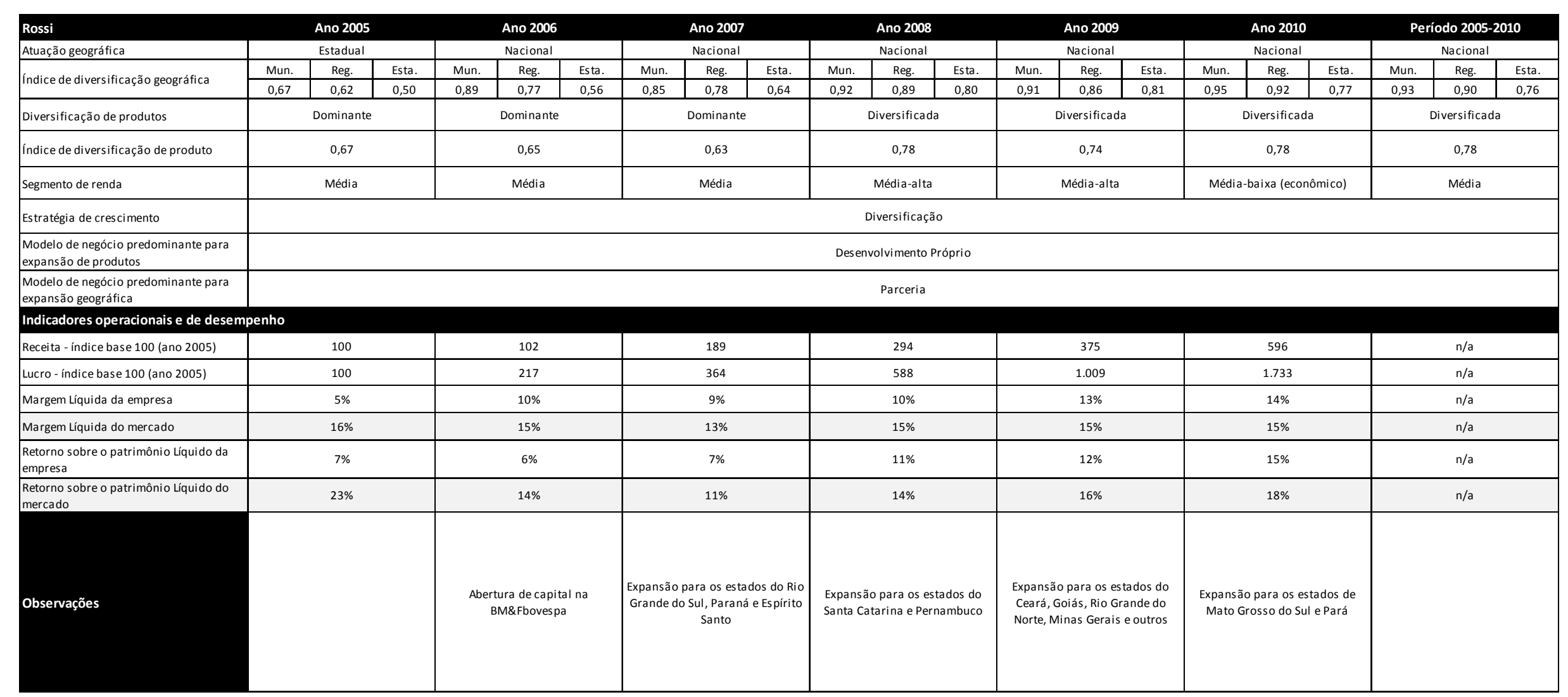

Fonte: Elaboração do autor 


\subsection{DESEMPENHO}

O presente item trata de apresentar os resultados da análise das influências da diversificação do portfólio e dos modelos de negócios utilizados nas estratégias de crescimento das empresas nos indicadores de desempenho. As discussões são apresentadas no capítulo nove.

Os quadros abaixo apresentam as classificações das empresas segundo o nível de diversificação de mercados e produtos, nos anos 2005, 2006, 2010 e consolidado para o período 2005-2010.

As cores representam o segmento de renda majoritário no portfólio de empreendimentos da empresa, conforme legenda localizada abaixo do primeiro quadro.

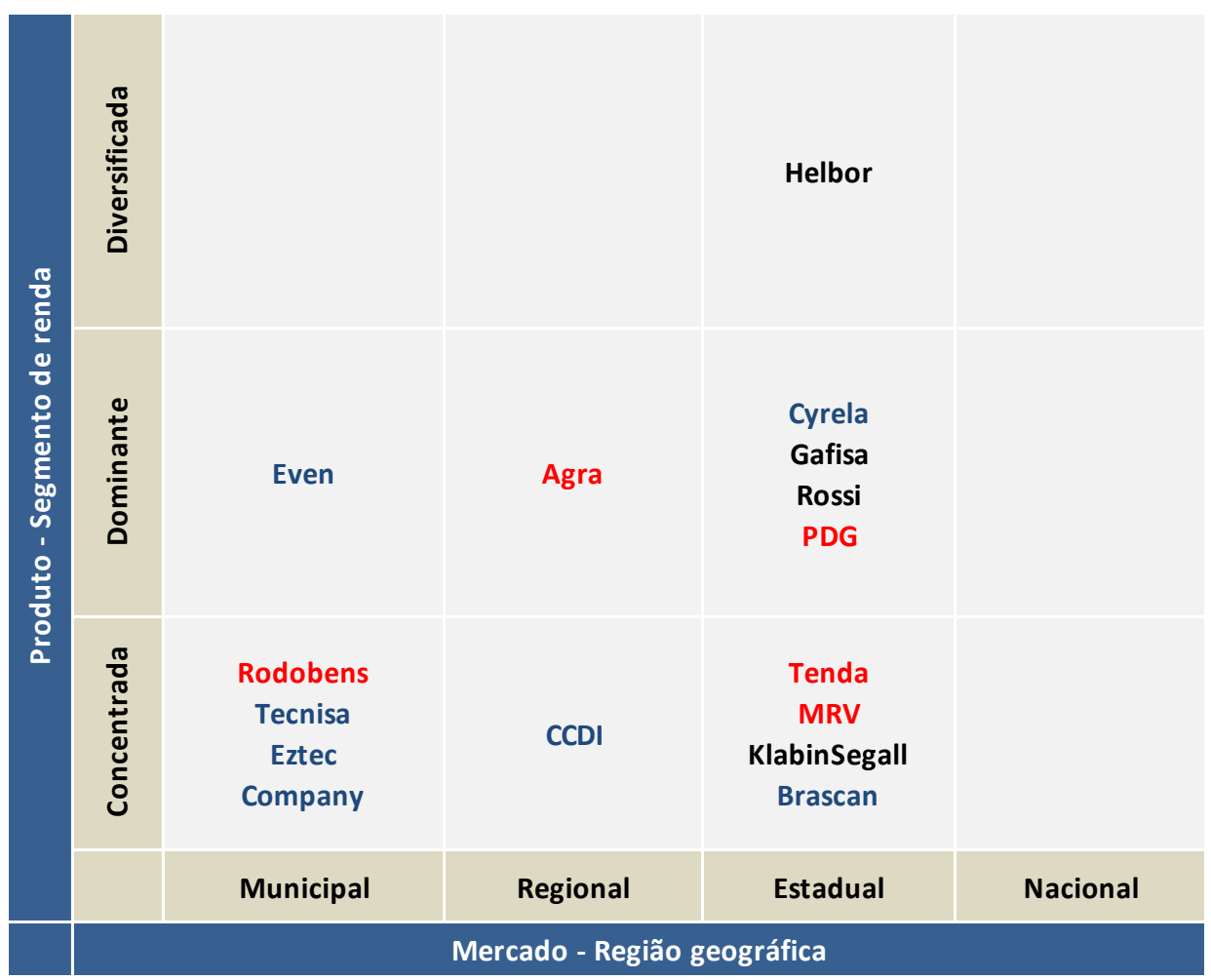

Legenda - escala de cores indica segmento de renda predominante

Azul - média-alta, alta renda e escritórios

Preto - média renda

Vermelho - média-baixa e baixa renda

Figura 30 - Diversificação do portfólio de empreendimentos das empresas no ano 2005

Fonte: elaboração do autor 


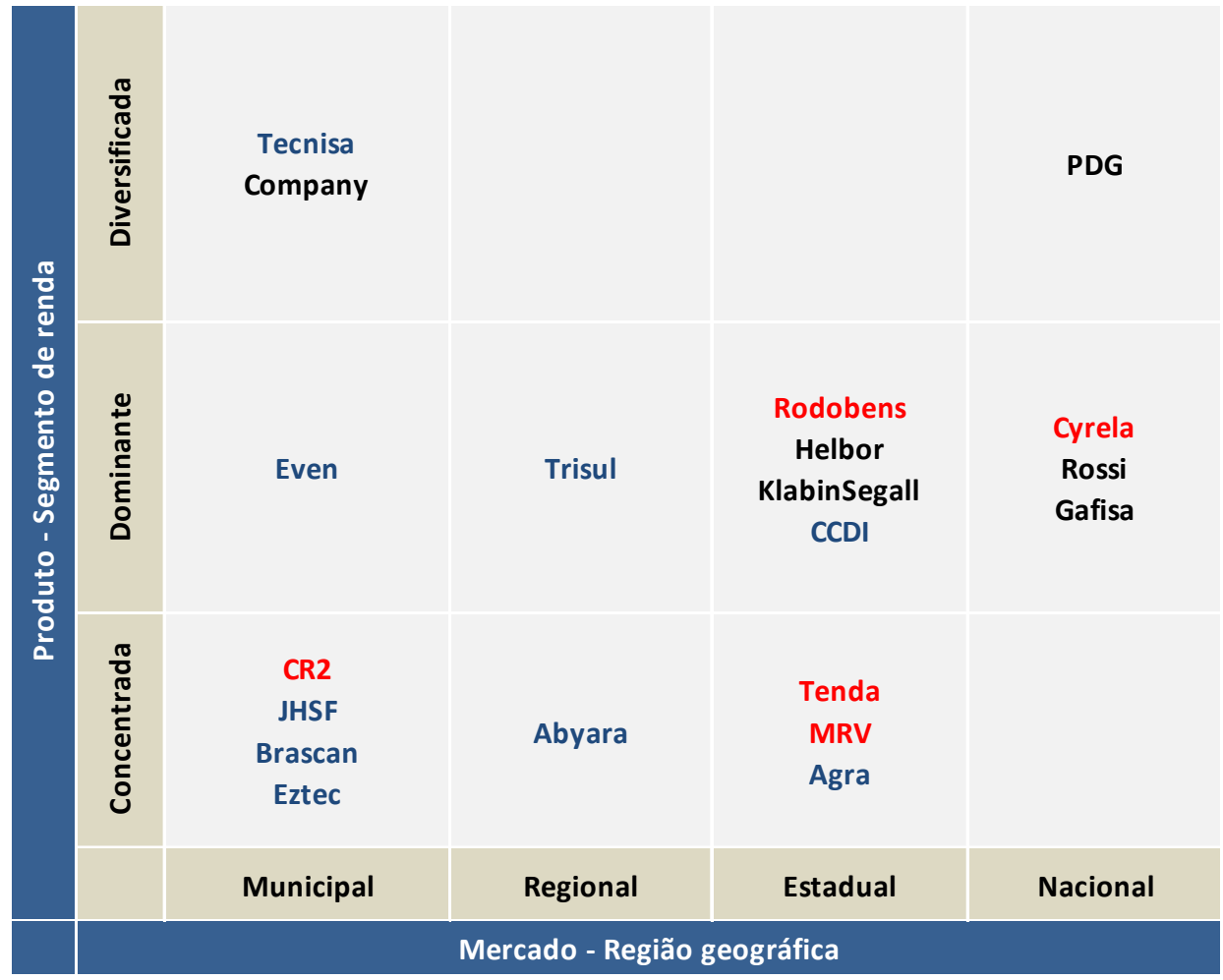

Figura 31 - Diversificação do portfólio de empreendimento das empresas no ano 2006 Fonte: elaboração do autor

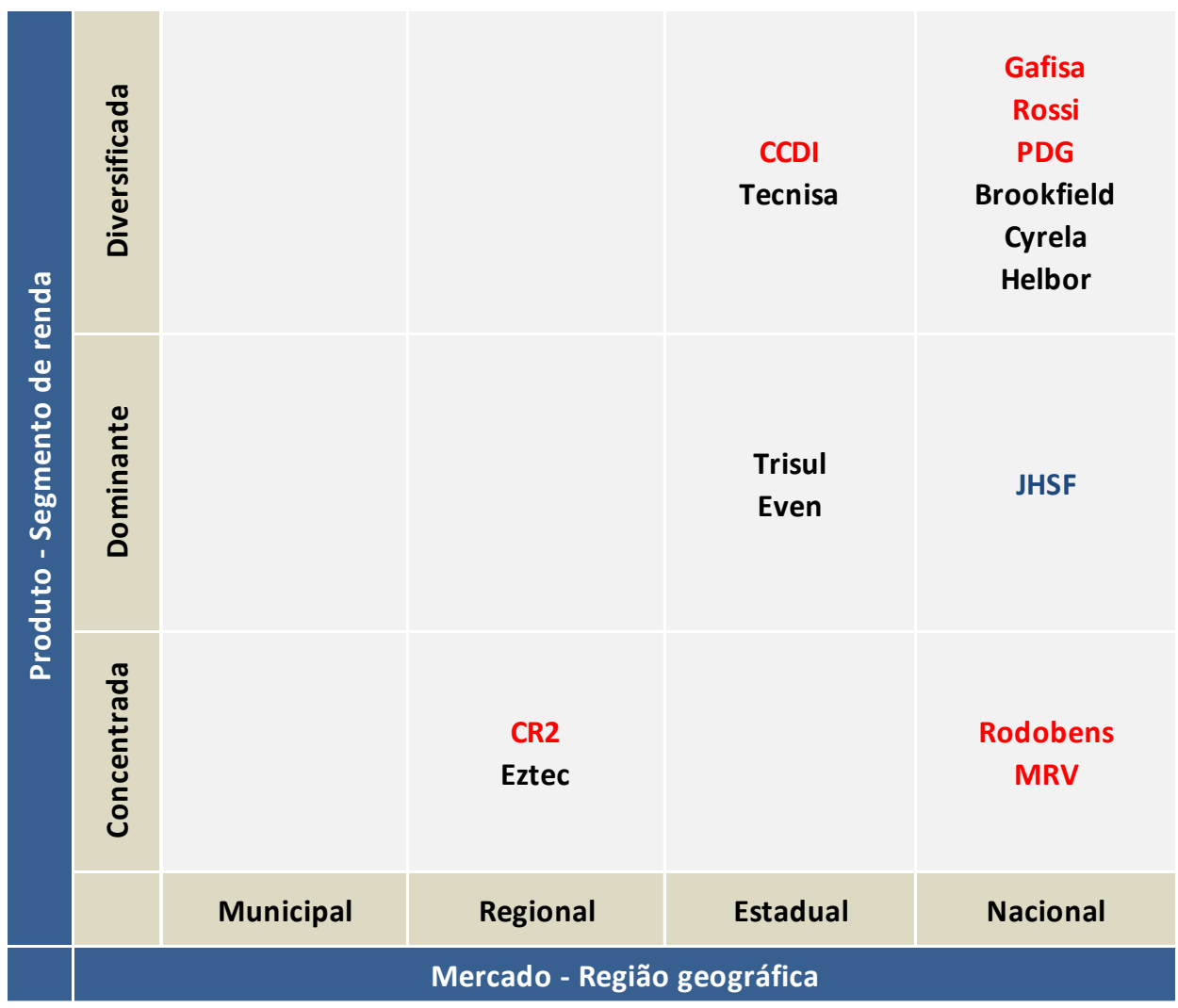

Figura 32 - Diversificação do portfólio de empreendimentos das empresas no ano 2010 Fonte: elaboração do autor 


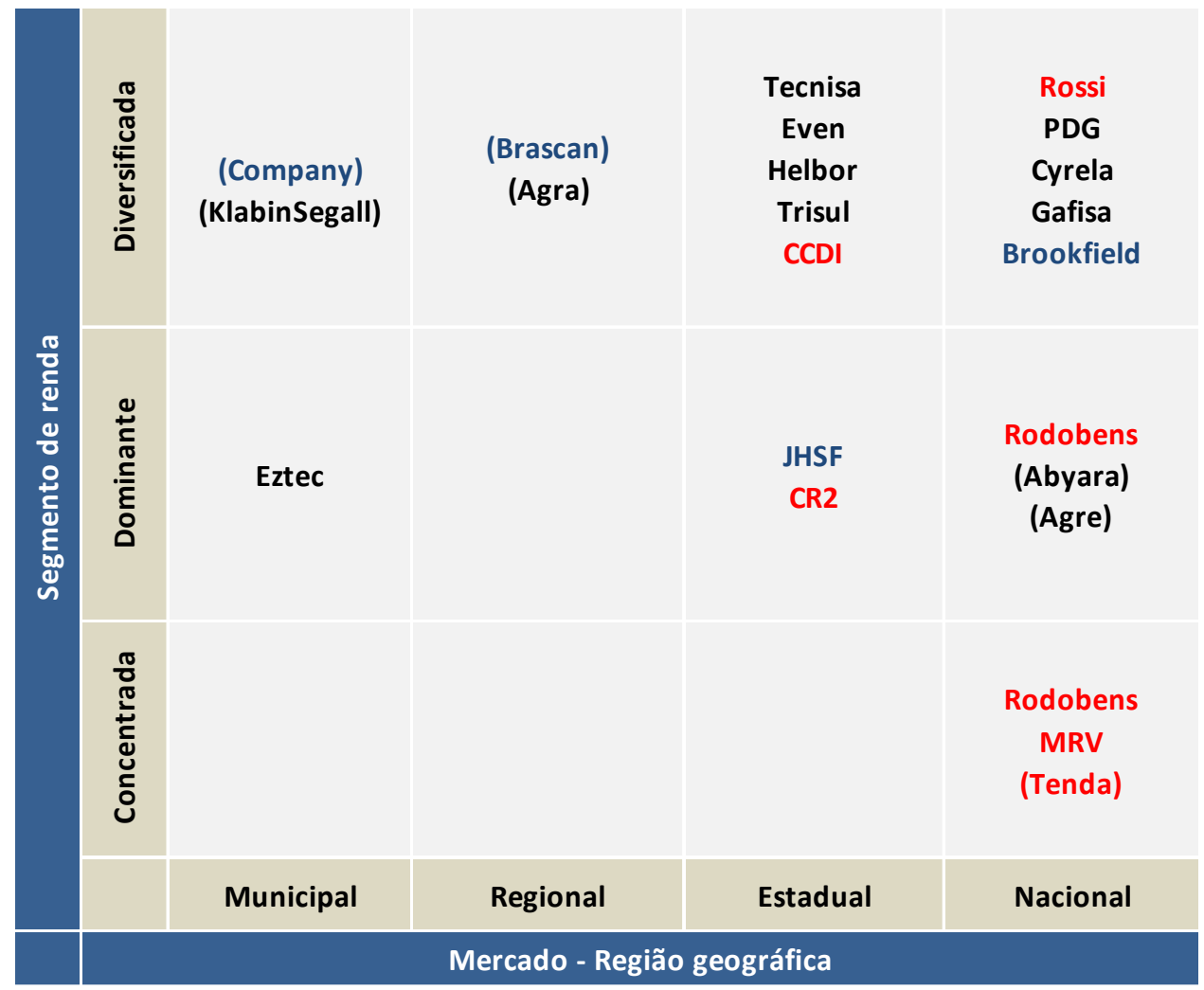

Figura 33 - Diversificação do portfólio de empreendimentos das empresas no período de 2005 a 2010

Fonte: elaboração do autor

$\mathrm{Na}$ figura acima, as empresas representadas entre parênteses foram descontinuadas ao longo do período devido a processos de aquisiões ou fusões. Assim, diversificação média no período de 2005 a 2010 foi calculada a partir do primeiro ano ao último de sua constituição. As tabelas apresentadas no capítulo sete, que trata do histórico de cada empresa no período, contêm as informações que suportaram a produção das figuras de números 30 a 33.

O quadro abaixo apresenta a classificação da diversificação e dos modelos de negócios das empresas no periodo analisado. 
Tabela 20 -Resumo da classificação das empresas no período de 2005 a 2010.

\begin{tabular}{|c|c|c|c|c|c|}
\hline EMPRESA & $\begin{array}{l}\text { Modelo de Negócio para } \\
\text { expansão de produtos }\end{array}$ & $\begin{array}{l}\text { Modelo de Negócio } \\
\text { para expansão } \\
\text { geográfica }\end{array}$ & $\begin{array}{l}\text { Segmento de renda } \\
\text { predominante } \\
(2006-2010)\end{array}$ & $\begin{array}{l}\text { Diversificação } \\
\text { geográfica }\end{array}$ & $\begin{array}{l}\text { Diversificação } \\
\text { produto }\end{array}$ \\
\hline PDG & Aquisição & Aquisição & Média-baixa (econômico) & Nacional & Diversificada \\
\hline CCDI & Aquisição & Parceria & Baixa renda (popular) & Estadual & Diversificada \\
\hline MRV & $\mathrm{n} / \mathrm{a}$ & $\begin{array}{l}\text { Desenvolvimento } \\
\text { próprio }\end{array}$ & Baixa renda (popular) & Nacional & Concentrada \\
\hline RODOBENS & $\mathrm{n} / \mathrm{a}$ & $\begin{array}{l}\text { Desenvolvimento } \\
\text { próprio }\end{array}$ & Baixa renda (popular) & Nacional & Concentrada \\
\hline GAFISA & Aquisição & Parceria & Média & Nacional & Diversificada \\
\hline ROSSI & Desenvolvimento Próprio & Parceria & Média & Nacional & Diversificada \\
\hline HELBOR & Desenvolvimento Próprio & Parceria & Média & Estadual & Diversificada \\
\hline EZTEC & Parceria & Parceria & Média & Municipal & Dominante \\
\hline BROOKFIELD & Desenvolvimento Próprio & Aquisição & Escritório & Nacional & Diversificada \\
\hline CYRELA & Desenvolvimento Próprio & Joint venture & Média & Nacional & Diversificada \\
\hline CR2 & Parceria & Parceria & Média-baixa (econômico) & Estadual & Dominante \\
\hline EVEN & Desenvolvimento Próprio & Parceria & Média & Estadual & Diversificada \\
\hline TECNISA & Desenvolvimento Próprio & Parceria & Média & Estadual & Diversificada \\
\hline TRISUL & Desenvolvimento Próprio & $\begin{array}{l}\text { Desenvolvimento } \\
\text { próprio }\end{array}$ & Média & Estadual & Diversificada \\
\hline
\end{tabular}

Fonte: Elaboração do autor

Da análise dos quadros, é possível observar as seguintes movimentações:

- As empresas Cyrela, Rossi, Gafisa e PDG compõem um grupo de companhias que diversificaram suas atividades para outras regiões geográficas e segmentos de renda. Ao contrário das demais empresas, já possuíam no ano de 2005 um portfólio de lançamentos de diversificação geográfica estadual e dominante de produtos.

A empresa PDG manteve atuação nos segmentos econômico e popular, e agregou ao seu portfólio novos produtos destinados a outros segmentos de renda. 
As empresas Cyrela, Gafisa e Rossi saíram de um portfólio com predominância nos segmentos de classe média a alta, e agregaram produtos destinados aos segmentos econômico e popular. Enquanto a Cyrela, apesar da expansão de produtos, manteve sua predominância na classe média, as empresas Rossi e Gafisa passaram a possuir um portfólio predominante nos segmentos de baixa renda.

Apesar das estratégias de crescimento terem sido equivalentes, as empresas diferem nos modelos de negócios empregados para a expansão geográfica e de produtos. Enquanto as empresas Rossi e Brookfield fizeram uso do desenvolvimento próprio de competências para a entrada nos segmentos de baixa renda, a PDG elegeu a aquisição de empresas especializadas e a Cyrela apresentou modelos diversificados, entre joint ventures, parcerias e aquisições.

- As empresas Rodobens e MRV são companhias que apresentaram escolhas equivalentes ao longo do período 2005 a 2010. Ambas as empresas possuem (e já possuíam em 2005) um portfólio de produtos concentrados nos segmentos popular, e apenas expandiram suas atividades para outras regiões geográficas por meio do desenvolvimento próprio de competências.

- As empresas Tecnisa, CCDI, Even, Helbor e Trisul diversificaram suas atividades para outros segmentos de renda e regiões geográficas. Porém, ao contrário do grupo das empresas Rossi, Cyrela, PDG e Gafisa, não chegaram a um nível de diversificação geográfica nacional $^{16}$. As empresas deste grupo partiram de um portfólio concentrado ou dominante nos segmentos de classe média-alta e alta renda, e por meio de modelos de negócios distintos, agregaram ao portfólio de empreendimentos produtos destinados aos segmentos econômico e popular. A empresa CCDI foi a única representante a possuir predominância nos segmentos de baixa renda, se considerado o

${ }^{16}$ Apesar da empresa Helbor ter apresentado portfólio de empreendimentos diversificado em nível nacional no ano de 2010, o portfólio médio do período possui diversificação estadual. 
portfólio de 2010 e agregado do período, enquanto as demais mantiveram maior exposição ao segmento de média renda.

As empresas Trisul, Helbor, Even e Tecnisa optaram pelo modelo de desenvolvimento próprio de competências para a realização de lançamentos no segmento econômico, e a CCDI por aquisição de construtora especializada.

Para a expansão para outras geografias, o modelo de parceria com empreendedores locais foi escolha comum para todas as empresas, com exceção da Trisul, que optou predominantemente pelo modelo de desenvolvimento próprio. Cabe destacar a estratégia da Even, que apesar de ter realizado joint venture e aquisição de empresa na região Sul do país, teve as parcerias como modelo de negócio predominante para expansão de mercados.

- As empresas CR2, JHSF e Eztec possuem em comum a escolha pela concentração de produtos, e no modelo de parceria para a entrada em novos segmentos ${ }^{17}$.

Em 2006 as três companhias possuíam concentração de lançamentos em nível municipal. As empresas diferem, no entanto, no nível de diversificação geográfica empregada ao longo do período. Enquanto a JHSF apresentou diversificação estadual, a CR2 apresentou diversificação regional e a Eztec municipal

- As empresas Brascan e Company saíram de uma concentração municipal nos segmentos de média a alta renda. Diversificaram suas atividades por meio, primeiramente, da fusão entre as organizações e, posteriormente, pela aquisição de empresa especializada no segmento econômico com concentração geográfica no Centro-Oeste brasileiro.

\footnotetext{
${ }^{17}$ No caso da JHSF e Eztec, foram realizadas parcerias como laboratório para conhecimento do segmento de baixa renda, não sendo os lançamentos relevantes em seus portfólios de empreendimento.
} 
- As empresas Abyara, Agra e KlabinSegall foram incorporadas numa única organização, a AGRE. As empresas possuíam portfólio de produtos diversificado geograficamente, em nível regional e nacional, e produtos para os segmentos de média a alta renda. No ano de 2010 a AGRE foi adquirida pela PDG. 


\subsubsection{Análise da influência do nível de diversificação do portfólio nos indicadores de desempenho}

Para a análise da influência da diversificação geográfica, foram selecionadas as empresas Rossi, Tecnisa, Even e Eztec, conforme escolhas efetuadas no período. Para tanto, os indicadores de desempenho da empresa Rossi, Grupo (A.1), que partiu de uma atuação estadual para nacional, são comparados com os indicadores de desempenho das empresas Tecnisa e Even (A.2), que iniciaram o período em nível municipal e o terminaram em nível estadual, e da empresa Eztec (A.3), de portfólio concentrado, conforme a tabela e os gráficos abaixo.

Tabela 21 - Empresas para análise da influência da diversificação geográfica

\begin{tabular}{|c|c|c|c|c|c|c|}
\hline Grupo & Empresa & $\begin{array}{l}\text { Modelo de negócio } \\
\text { Expansão de } \\
\text { produtos }\end{array}$ & $\begin{array}{l}\text { Modelo de } \\
\text { negócio } \\
\text { Expansão } \\
\text { geográfica }\end{array}$ & $\begin{array}{l}\text { Segmento de renda } \\
\text { predominante } \\
(2010-2006)\end{array}$ & $\begin{array}{l}\text { Diversificação } \\
\text { geográfica }\end{array}$ & $\begin{array}{l}\text { Diversificação } \\
\text { produto }\end{array}$ \\
\hline A. 1 & Rossi & \multirow{3}{*}{$\begin{array}{c}\text { Desenvolvimento } \\
\text { Próprio }\end{array}$} & \multirow{4}{*}{ Parceria } & \multirow{4}{*}{ Média } & Nacional & Diversificada \\
\hline \multirow{2}{*}{ A.2 } & Even & & & & \multirow{2}{*}{ Estadual } & \multirow{2}{*}{ Diversificada } \\
\hline & Tecnisa & & & & & \\
\hline A.3 & Eztec & Parceria & & & Municipal & Dominante \\
\hline
\end{tabular}

Fonte: elaboração do autor

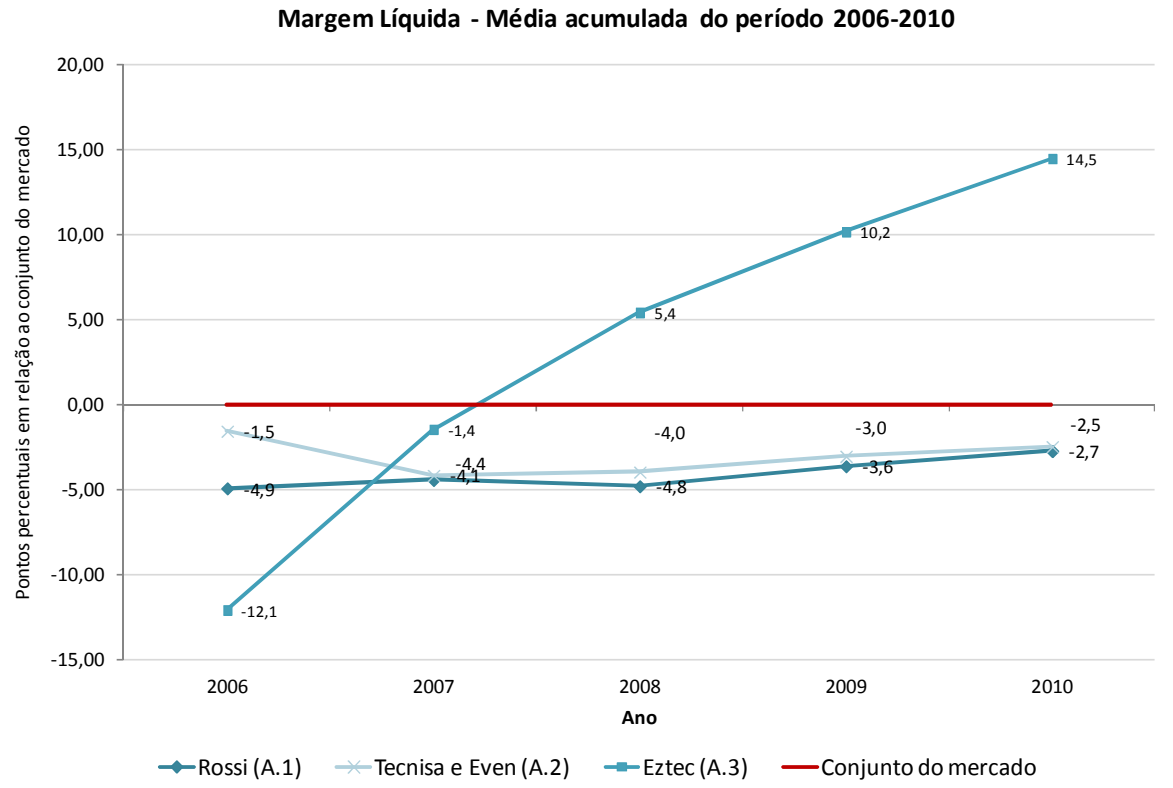

Gráfico 27 - Evolução da margem líquida do grupo de empresas da tabela 21

Fonte: elaboração do autor 


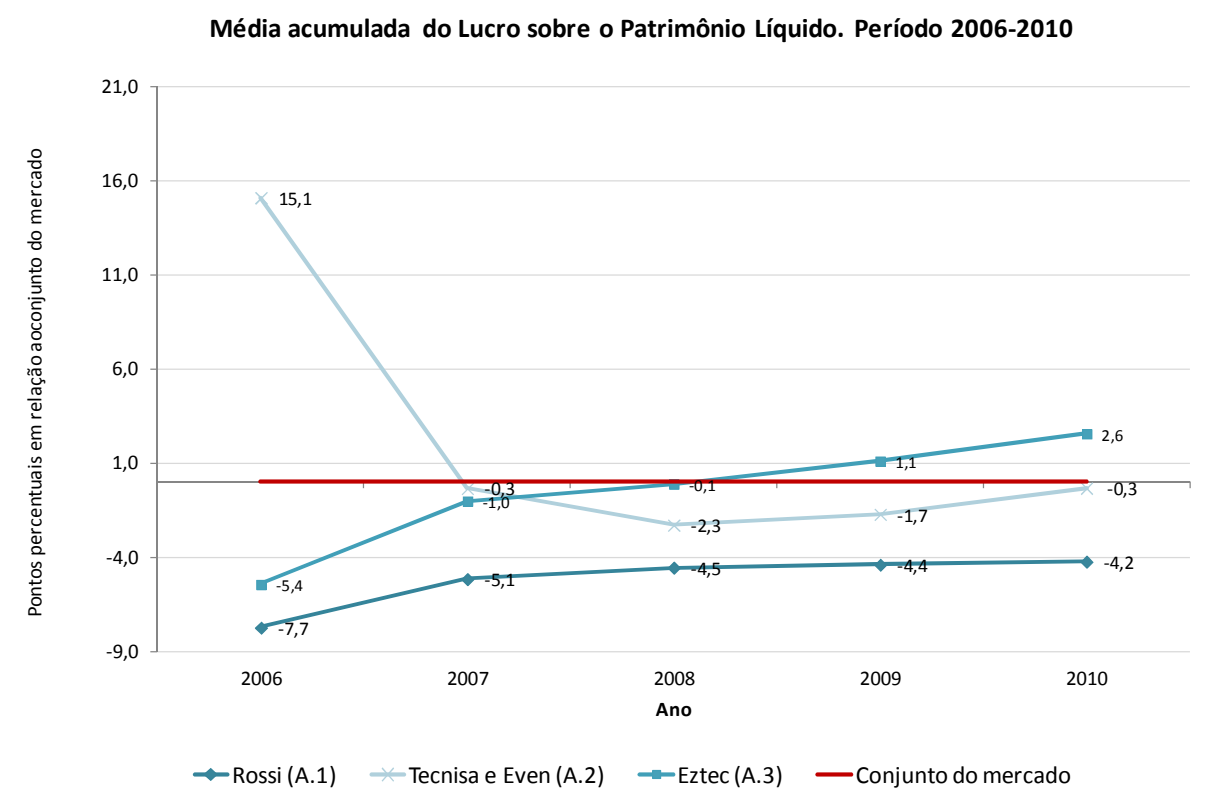

Gráfico 28 - Evolução do lucro sobre o patrimônio líquido do grupo de empresas da tabela 21 Fonte: Elaboração do autor

Com o objetivo de verificar outras evidências, foram comparados os grupos (B.1), (B.2) e (A.3), cujas empresas estão demonstradas no quadro abaixo. Na primeira amostra, constam todas as empresas que apresentaram diversificação de produtos e atuação nacional, desta vez ignorando as escolhas do modelo de negócio, e elegendo apenas as que apresentam concentração predominante na média renda. $\mathrm{Na}$ amostra (B.2), estão as empresas diversificadas por produtos e de atuação estadual. 
Tabela 22 - Empresas para análise da influência da diversificação geográfica

\begin{tabular}{|c|c|c|c|c|c|c|}
\hline Grupo & Empresa & $\begin{array}{l}\text { Modelo de negócio } \\
\text { Expansão de } \\
\text { produtos }\end{array}$ & $\begin{array}{l}\text { Modelo de } \\
\text { negócio } \\
\text { Expansão } \\
\text { geográfica }\end{array}$ & $\begin{array}{l}\text { Segmento de renda } \\
\text { predominante } \\
(2010-2006)\end{array}$ & $\begin{array}{c}\text { Diversificação } \\
\text { geográfica }\end{array}$ & $\begin{array}{c}\text { Diversificação } \\
\text { produto }\end{array}$ \\
\hline \multirow{3}{*}{ B.1 } & Gafisa & Aquisição & Parceria & Média & Nacional & Diversificada \\
\hline & Rossi & $\begin{array}{l}\text { Desenvolvimento } \\
\text { Próprio }\end{array}$ & Parceria & Média & Nacional & Diversificada \\
\hline & Cyrela & Jesenvolvimento Própric & i Joint venture & Média & Nacional & Diversificada \\
\hline \multirow{4}{*}{ B.2 } & Even & $\begin{array}{c}\text { Desenvolvimento } \\
\text { Próprio }\end{array}$ & Parceria & Média & Estadual & Diversificada \\
\hline & Helbor & $\begin{array}{c}\text { Desenvolvimento } \\
\text { Próprio }\end{array}$ & Parceria & Média & Estadual & Diversificada \\
\hline & Tecnisa & $\begin{array}{c}\text { Desenvolvimento } \\
\text { Próprio }\end{array}$ & Parceria & Média & Estadual & Diversificada \\
\hline & Trisul & $\begin{array}{c}\text { Desenvolvimento } \\
\text { Próprio }\end{array}$ & $\begin{array}{c}\text { Desenvolvimento } \\
\text { próprio }\end{array}$ & Média & Estadual & Diversificada \\
\hline A. 3 & Eztec & Parceria & Parceria & Média & Municipal & Dominante \\
\hline
\end{tabular}

Fonte: elaboração do autor

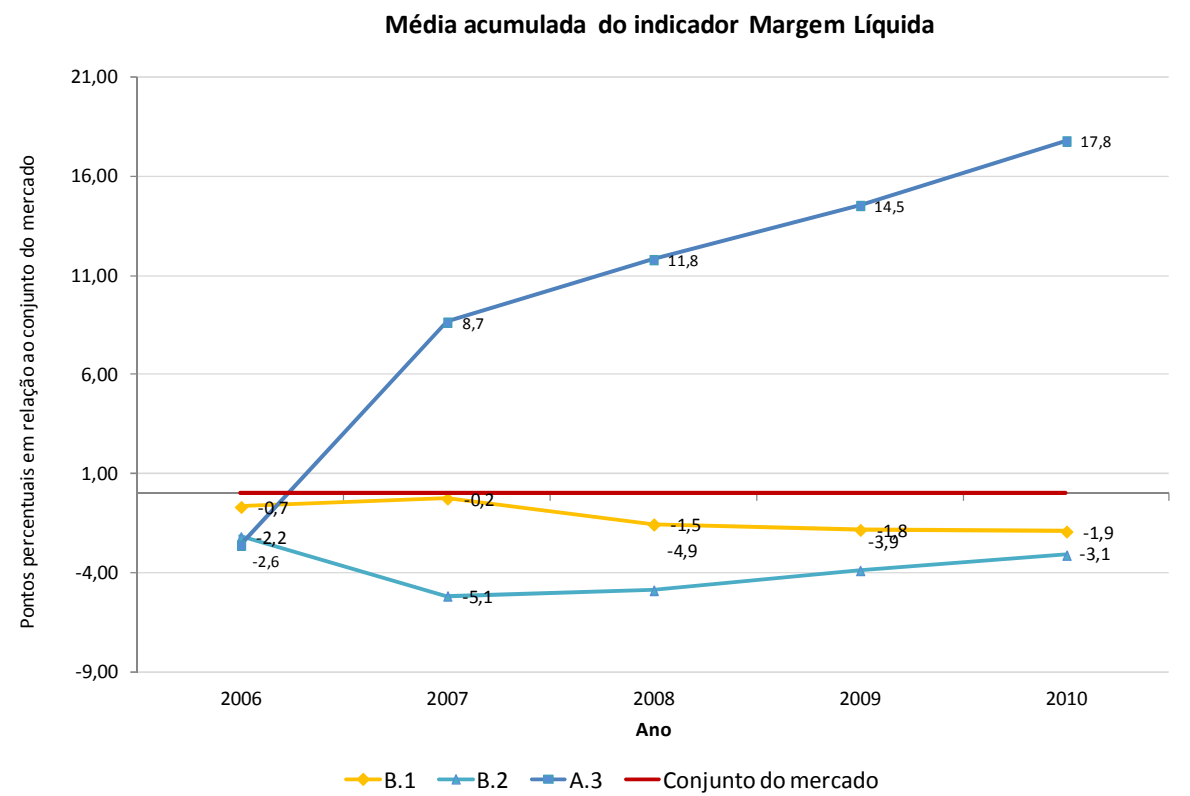

Gráfico 29 - Evolução da margem líquida do grupo de empresas da tabela 22

Fonte: elaboração do autor 


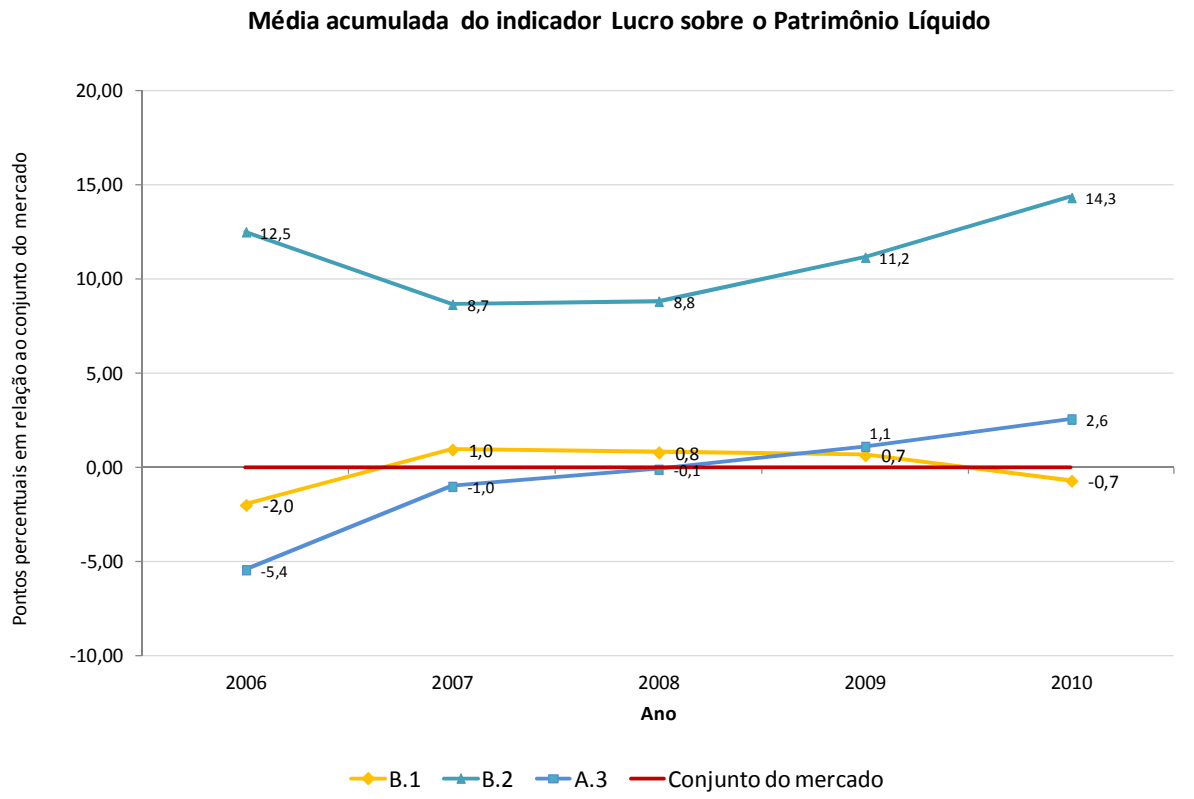

Gráfico 30 - Evolução do lucro sobre o patrimônio líquido do grupo de empresas da tabela 22 Fonte: elaboração do autor

Com o objetivo de investigar a influência da concentração de produtos no desempenho das empresas, foram selecionados dois conjuntos de companhias tabela abaixo: o primeiro (C1) é composto pelas empresas com concentração na baixa renda; e o segundo $(\mathrm{C} 2)$ pelas firmas diversificadas por produtos. A característica comum de ambos os grupos é a atuação em nível nacional de todas as suas companhias.

Tabela 23 - Empresas para análise da influência da diversificação de produto

\begin{tabular}{|l|l|c|c|c|c|c|}
\hline Grupo & EMPRESA & $\begin{array}{c}\text { Modelo de Negócio para } \\
\text { expansão de produtos }\end{array}$ & $\begin{array}{c}\text { Modelo de Negócio } \\
\text { para expansão } \\
\text { geográfica }\end{array}$ & $\begin{array}{c}\text { Segmento de renda } \\
\text { predominante } \\
\text { (2006-2010) }\end{array}$ & $\begin{array}{c}\text { Diversificação } \\
\text { geográfica }\end{array}$ & $\begin{array}{c}\text { Diversificação } \\
\text { produto }\end{array}$ \\
\hline C.1 & MRV & n/a & $\begin{array}{c}\text { Desenvolvimento } \\
\text { próprio }\end{array}$ & Baixa renda (popular) & Nacional & Concentrada \\
\hline & RODOBENS & n/a & $\begin{array}{c}\text { Desenvolvimento } \\
\text { próprio }\end{array}$ & Baixa renda (popular) & Nacional & Concentrada \\
\hline & PDG & Aquisição & Aquisição & Média-baixa (econômico) & Nacional & Diversificada \\
\hline C.2 & GAFISA & Aquisição & Parceria & Média & Nacional & Diversificada \\
\hline & ROSSI & Desenvolvimento Próprio & Parceria & Média & Nacional & Diversificada \\
\hline & Cyrela & Desenvolvimento Próprio & Joint venture & Média & Nacional & Diversificada \\
\hline
\end{tabular}

Fonte: elaboração do autor 
Os gráficos abaixo apresentam a evolução dos indicadores Margem Líquida e Lucro sobre o Patrimônio Líquido, acumulados desde o ano de 2006. Verificase que o grupo $\mathrm{C} 1$, composto pelas empresas de concentração de produto, apresenta indicadores acima do conjunto do mercado, enquanto o grupo $\mathrm{C} 2$, composto pelas empresas diversificadas, situa-se abaixo do conjunto.

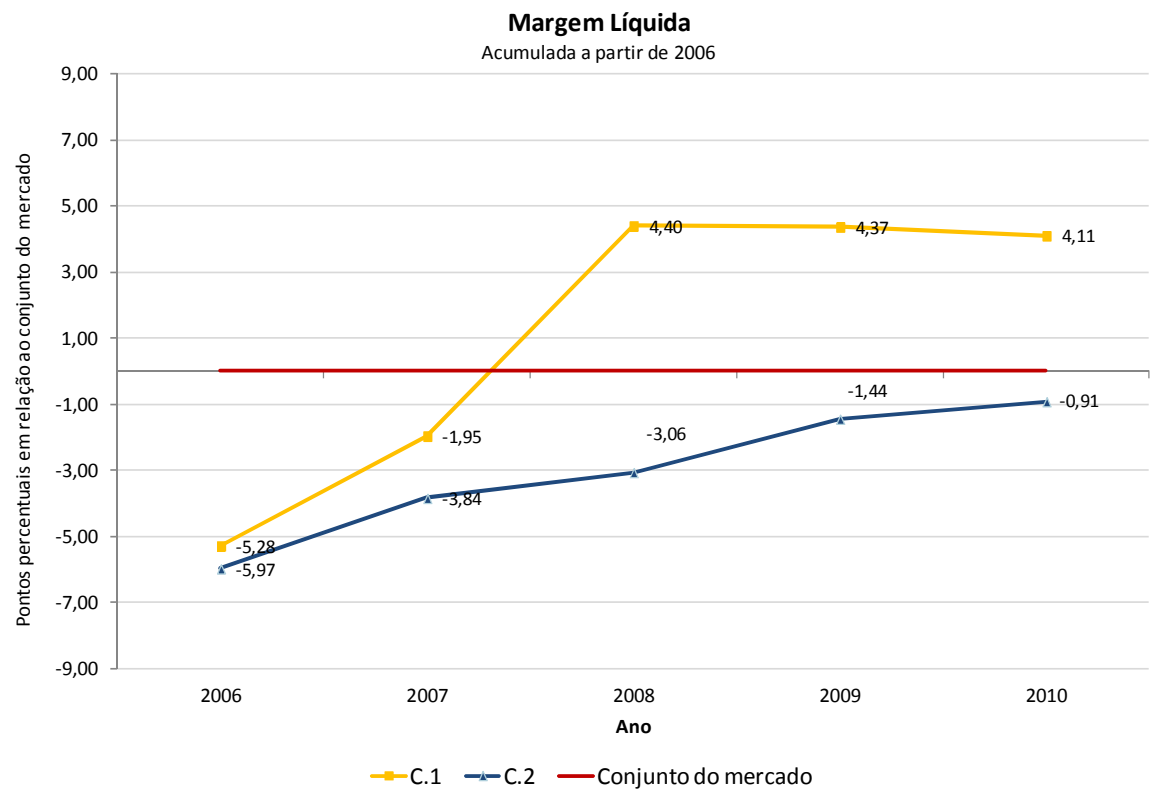

Gráfico 31 - Evolução da margem líquida do grupo de empresas da tabela acima Fonte: elaboração do autor

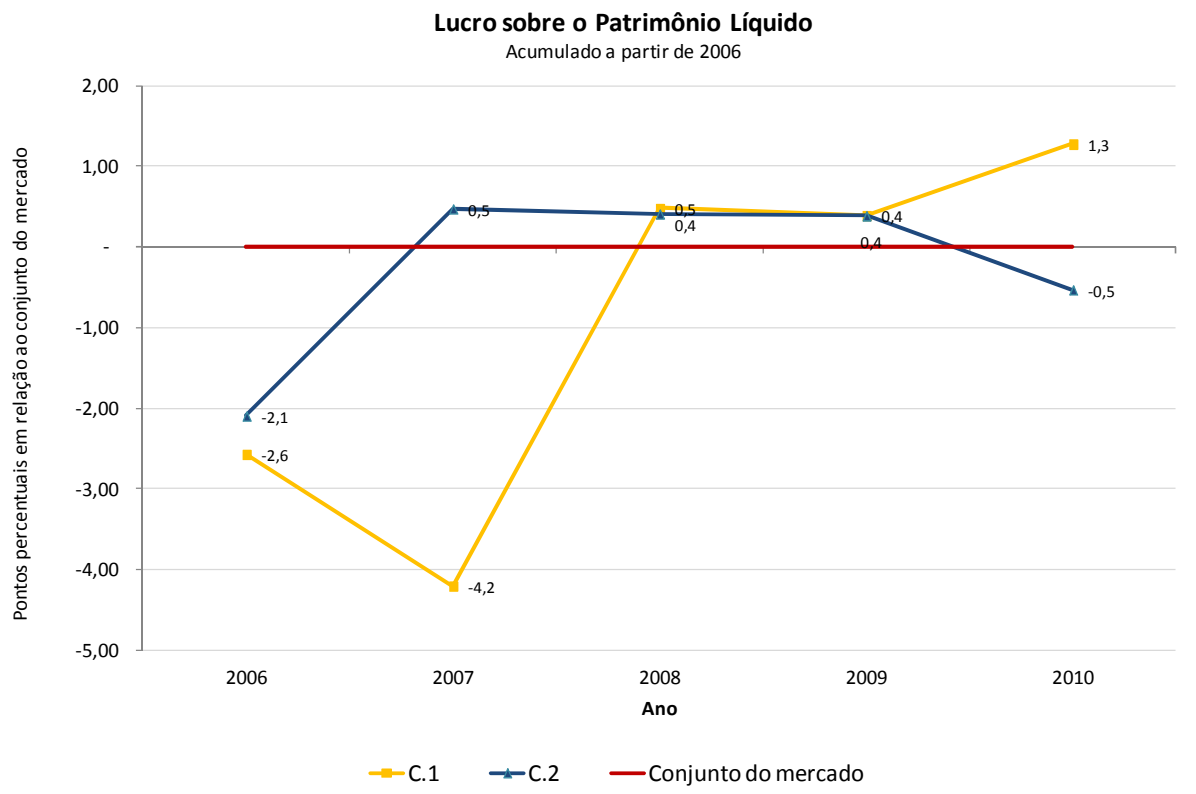

Gráfico 32 - Evolução do lucro sobre o patrimônio líquido do grupo de empresas da tabela acima

Fonte: elaboração do autor 
Feita a análise dos grupos, com o objetivo de investigar diferenças de desempenho entre as empresas que adotaram distintos níveis de diversificação geográfica e de produtos, as tabelas abaixo apresentam os indicadores de desempenho para cada empresa, em pontos percentuais em relação ao conjunto do mercado, e sua diferença entre o início e final do perído, de modo a permitir o entendimento de como cada empresa evoluiu nos indicadores durante o período em relação ao conjunto do mercado.

Tabela 24 - Margem Líquida por empresa

\begin{tabular}{|l|c|c|c|}
\multirow{2}{*}{\multicolumn{1}{c}{ EMPRESA }} & \multicolumn{2}{|c|}{ MARGEM LíQUIDA } \\
\cline { 2 - 4 } & Período 2006-2010 & Ano 2006 / 2007* & $\begin{array}{c}\text { DIFERENÇA 2010 - } \\
\text { 2006/2007 }\end{array}$ \\
\cline { 2 - 4 } & [pontos percentuais em relação ao conjunto do mercado] \\
\hline BROOKFIELD (Dados da BRASCAN em 2007) & $-3,5$ & 8,5 & $-12,0$ \\
\hline CCDI & $-5,5$ & $-13,4$ & $+7,9$ \\
\hline CR2 & $-4,7$ & $-15,2$ & $+10,5$ \\
\hline CYRELA & 1,0 & 6,5 & $-5,5$ \\
\hline EVEN & $-3,6$ & $-4,8$ & $+1,1$ \\
\hline EZTEC & 14,5 & $-12,1$ & $+26,6$ \\
\hline GAFISA & $-5,6$ & $-9,2$ & $+3,5$ \\
\hline HELBOR & $-1,2$ & $-3,9$ & $+2,7$ \\
\hline MRV & 5,9 & $-2,8$ & $+8,8$ \\
\hline PDG & 0,4 & $-9,9$ & $+10,3$ \\
\hline RODOBENS & $-2,5$ & $-10,4$ & $+7,9$ \\
\hline ROSSI & $-2,7$ & $-4,9$ & $+2,2$ \\
\hline TECNISA & $-0,8$ & 1,8 & $-2,5$ \\
\hline TRISUL* & $-8,3$ & $-3,5$ & $-4,8$ \\
\hline
\end{tabular}

*Ao contrário das demais empresas, a Trisul iniciou legalmente suas atividades no exercício de 2007, tendo, portanto, os indicadores de desempenho calculados a partir desta data.

Fonte: elaboração do autor 
Tabela 25 - Lucro sobre o Patrimônio Líquido por empresa

\begin{tabular}{|c|c|c|c|}
\hline \multirow{3}{*}{ EMPRESA } & \multicolumn{3}{|c|}{ LUCRO SOBRE O PATRIMÔNIO LÍQUIDO } \\
\hline & ANO 2010 & ANO $2007^{\star}$ & $\begin{array}{c}\text { DIFERENÇA } \\
2010 \text { - } 2007\end{array}$ \\
\hline & \multicolumn{3}{|c|}{ [pontos percentuais em relação ao conjunto do mercado] } \\
\hline BROOKFIELD (BRASCAN em 2007) & $-4,1$ & 2,3 & $-6,4$ \\
\hline CCDI & $-5,8$ & $-10,6$ & $+4,8$ \\
\hline CR2 & $-8,2$ & $-9,4$ & $+1,2$ \\
\hline CYRELA & 3,3 & 2,4 &,+ 9 \\
\hline EVEN & 0,8 & 17,4 & $-16,6$ \\
\hline EZTEC & 2,6 & $-5,2$ & $+7,8$ \\
\hline GAFISA & $-3,9$ & $-6,0$ & $+2,1$ \\
\hline HELBOR & 1,5 & $-8,1$ & $+9,6$ \\
\hline MRV & 3,4 & 1,0 & $+2,4$ \\
\hline PDG & 0,0 & $-8,9$ & $+8,9$ \\
\hline RODOBENS & $-5,5$ & $-9,0$ & $+3,5$ \\
\hline ROSSI & $-4,2$ & $-7,5$ & $+3,3$ \\
\hline TECNISA & $-1,4$ & 14,1 & $-15,5$ \\
\hline TRISUL* & $-7,7$ & $-2,0$ & $-5,7$ \\
\hline
\end{tabular}

Fonte: Elaboração do autor

\subsubsection{Análise da influência dos modelos de negócios nos indicadores de desempenho}

A seguir são feitas investigações com o intuito de analisar o efeito das escolhas de diferentes modelos de negócios, como estratégia de crescimento e diversificação, nos indicadores de desempenho das empresas.

Tendo em vista a inexistência de amostras que permitam analisar a influência de cada atributo isoladamente, optou-se por agregar as companhias em modelos de empresas, compostas por um conjunto de decisões de estratégias de crescimento e modelos de negócios diferentes entre si. Assim, ao invés de analisar a influência de cada atributo, será feita a análise comparativa do desempenho dos seguintes modelos de empresas:

- Empresas de concentração no segmento de baixa renda, que expandiram para novas geografias por meio do desenvolvimento próprio de competências: MRV e Rodobens (Grupo C1); 
- Empresas de atuação nacional e portfólio de produtos diversificado, que expandiram para novos segmentos de renda por meio do desenvolvimento próprio de competências: Rossi e Brookfield (Grupo D1);

- Empresa de atuação nacional e portfólio de produtos diversificado, que expandiu para novos segmentos e geografias por meio de aquisições: PDG (Grupo D2);

- Empresa de atuação nacional e portfólio de produtos diversificado, que expandiu para novos segmentos e geografias por meio de um portfólio diversificado de modelos de negócios: Cyrela (Grupo D3);

O comportamento dos indicadores de desempenho é apresentado nos gráficos abaixo.

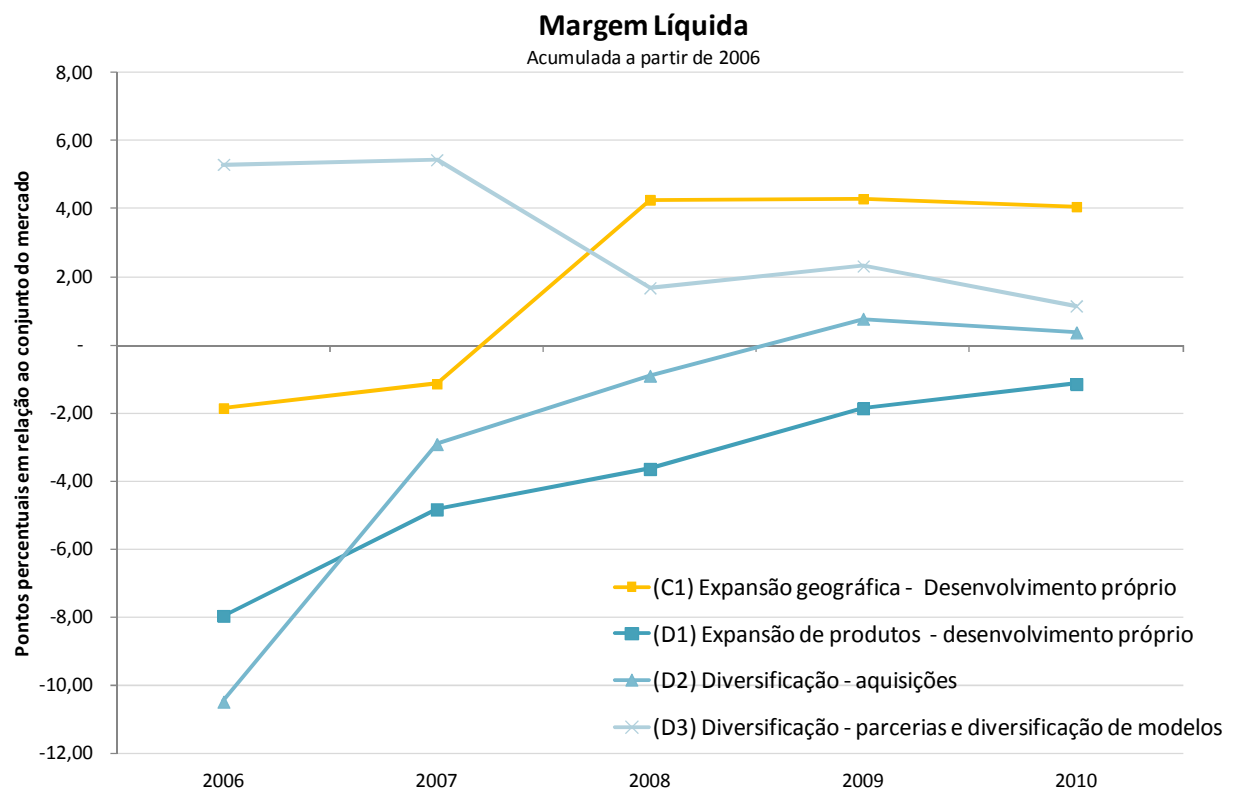

Gráfico 33 - Evolução da margem líquida em relação ao conjunto do mercado para diferentes estratégias de crescimento e modelos de negócios Fonte: elaboração do autor 


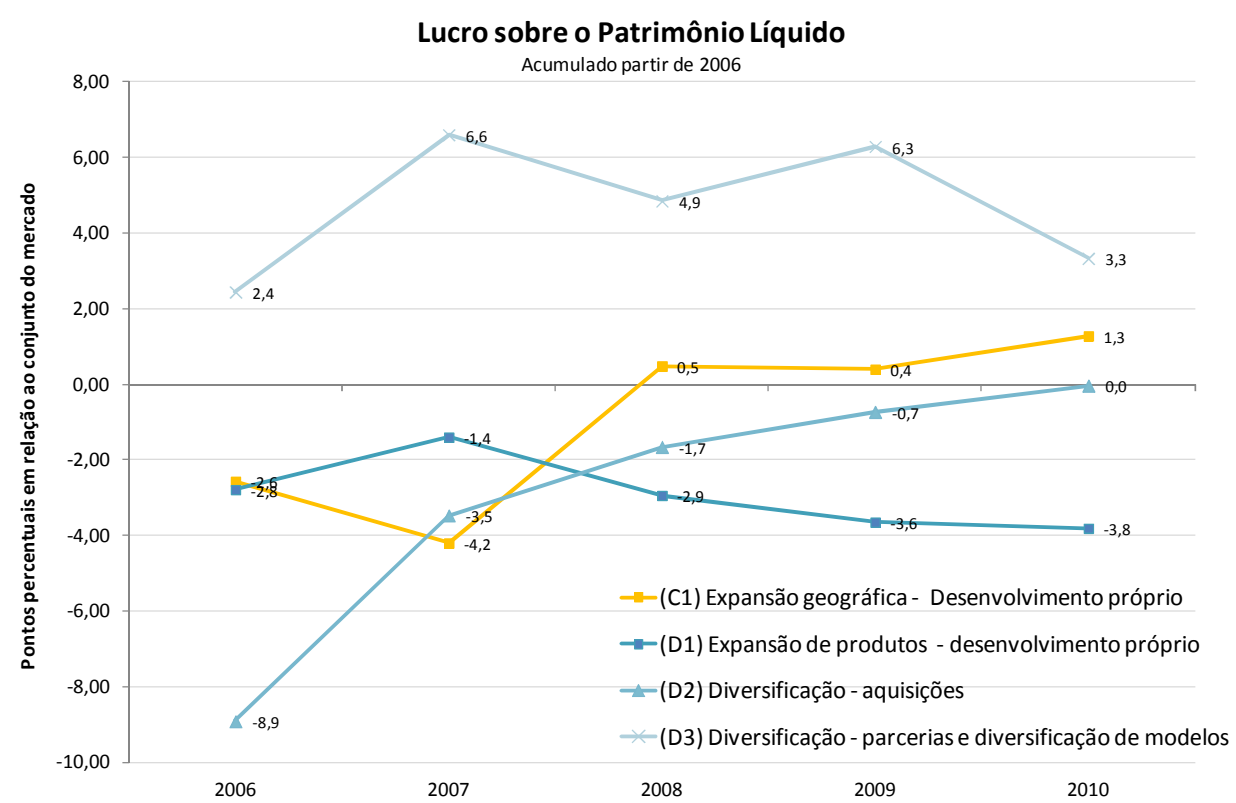

'Gráfico 34 - Evolução do lucro sobre o patrimônio líquodo em relação ao conjunto do mercado para diferentes estratégias de crescimento e modelos de negócios Fonte: elaboração do autor

Os resultados sugerem que as empresas de concentração no segmento de baixa renda, de atuação nacional e que expandiram para novas regiões geográficas por meio de aquisições e desenvolvimento próprio de competências (C1), apresentaram indicadores de margem líquida superior em relação ao conjunto do mercado e aos demais grupos aqui analisados.

O modelo de empresa de aquisição para entrada na baixa renda (D2) mostrouse com ambos os indicadores crescentes ao longo do período, sendo sua posição atual próxima ao valor do conjunto do mercado.

As empresas de portfólio diversificado, de atuação nacional e que optaram pelo desenvolvimento próprio de competências para a entrada nos segmentos popular e econômico (D1) apresentaram resultados inferiores aos outros modelos e ao conjunto do mercado. Destaca-se, no entanto, a tendência de evolução positiva da margem líquida ao longo do período. 
Já o modelo diversificado de modelos de negócios, com predominância de parcerias e joint ventures (D3), apresentou margem líquida intermediária entre os modelos de empresas. No entanto, sua tendência é decrescente ao longo do período.

\subsubsection{Análise do comportamento dos indicadores de desempenho}

As análises realizadas até o presente confrontaram empresas com diferentes estratégias a fim de verificar as diferenças de desempenho. Os gráficos abaixo apresentam análise contrário, ao agrupar as empresas conforme similaridade do comportamento dos indicadores de desempenho.

O Gráfico 35 apresenta a distância dos indicadores em relação à média acumulada do período, em pontos percentuais, a partir de 2006. O objetivo da análise é verificar o comportamento médio das empresas em relação ao conjunto do mercado.

Em seguida, o Gráfico 36 tem como objetivo demonstrar a tendência dos indicadores de desempenho em relação ao conjunto do mercado, entre o período 2006-2010. Trata-se do valor médio acumulado do indicador no período subtraído pelo valor do ano de 2006.

Conforme já citado, as empresas JHSF, Agre, KlabinSegall, Abyara, Brascan, Company e Agra, apesar de terem suas estratégias analisadas, não Figuram na amostra para análise de desempenho, devido aos motivos expostos no item metodologia.

No capítulo que segue, os resultados aqui demonstrados são interpretados e analisados em maior profundidade. 


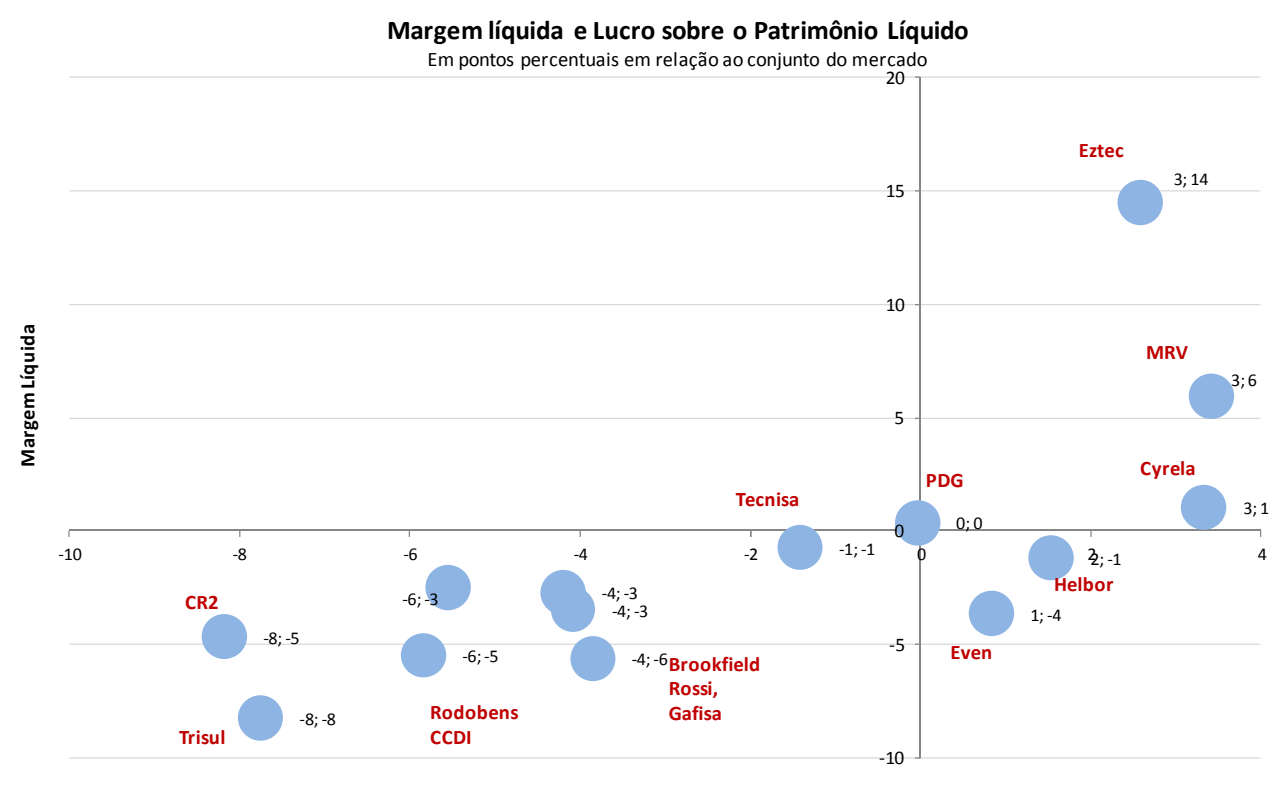

Lucro sobre o patrimônio líquido

Gráfico 35 -Margem Líquida e Lucro sobre o Patrimônio Líquido por empresa em relação ao conjunto do mercado - acumulado para o período 2006-2010.

Fonte: Elaboração do autor

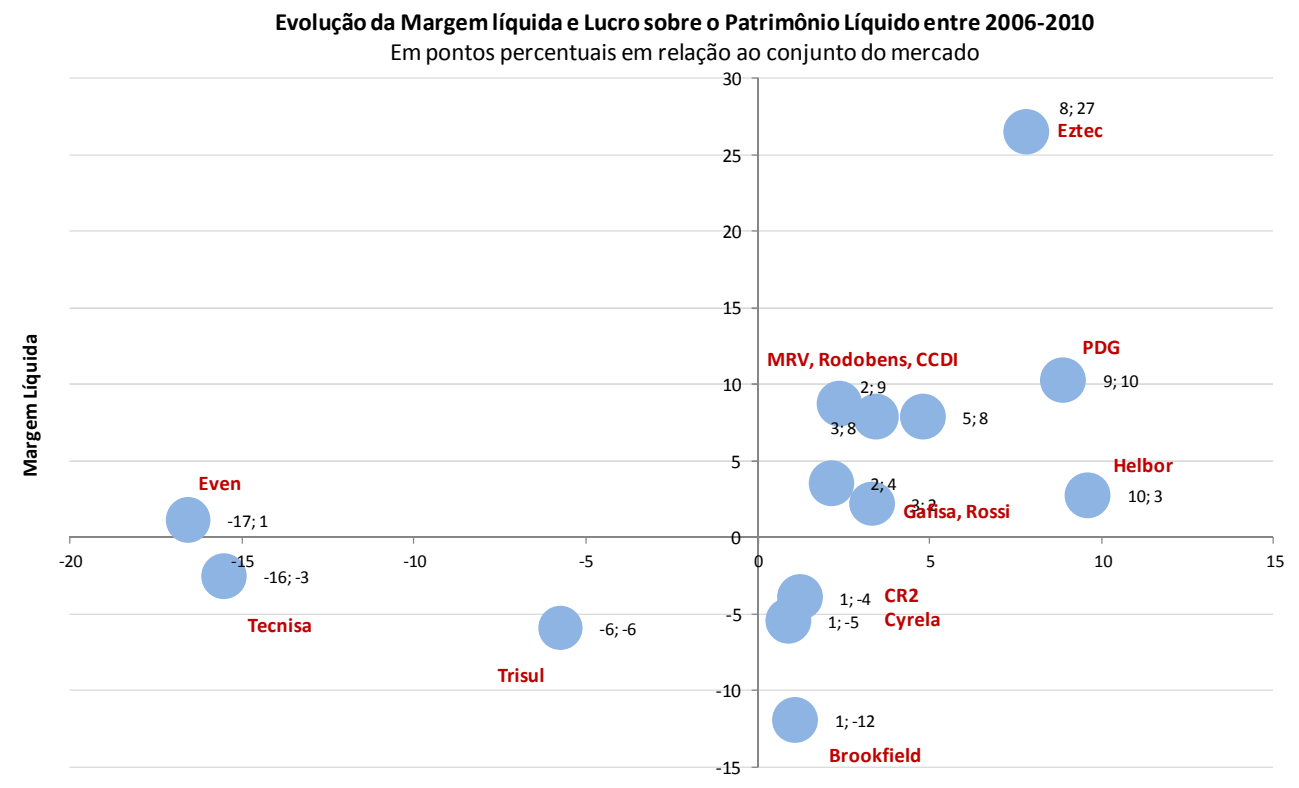

Lucro sobre o patrimônio líquido

Gráfico 36 - Evolução em pontos percentuais sobre o conjunto do mercado dos indicadores de desempenho entre 2006-2010.

Fonte: Elaboração do autor 


\section{DISCUSSÕES E INTERPRETAÇÃO DOS RESULTADOS}

Diante dos resultados obtidos no capítulo anterior, o presente busca consolidálos e interpretá-los, com vistas a buscar entender os motivos das diferenças de desempenho identificadas, e como derivar daí contribuições para a formulação da estratégia empresarial para as empresas do setor.

\subsection{Resumo}

Listam-se abaixo as diferenças de desempenho identificadas.

1. MODELO DE CONCENTRAÇÃO DE PRODUTOS E DIVERSIFICAÇÃO GEOGRÁFICA [MRV vs. conjunto]: O modelo de empresa de concentração de produtos e diversificação geográfica apresentou resultados superiores em relação às demais empresas igualmente diversificadas;

2. MODELO DE CONCENTRAÇÃO DE MERCADO E DOMINÂNCIA DE PRODUTOS [Eztec vs. conjunto de empresas]: O modelo de concentração municipal e de produto dominante apresentou resultados acima do conjunto de empresas no período;

3. CONCENTRAÇÃO DE PRODUTOS versus DIVERSIFICAÇÃO DE PRODUTOS [MRV e Rodobens vs. PDG, Cyrela, Gafisa e Rossi]: Entre as empresas diversificadas geograficamente, as empresas de concentração de produtos na baixa renda apresentaram maior margem líquida e retorno sobre o patrimônio líquido do que as empresa diversificadas. Todas as empresas apresentaram tendência de crescimento nos indicadores de desempenho ao longo do período;

4. AQUISIÇÕES versus DESENVOLVIMENTO PRÓPRIO PARA ENTRADA NA BAIXA RENDA [PDG vs. ROSSI e Brookfield]: A empresa que expandiu para os produtos de baixa renda por meio de 
aquisições apresentou indicadores de margem líquida e retorno sobre o patrimônio líquido maior em relação às empresas que fizeram uso do desenvolvimento próprio de competências;

5. MODELO DE ENTRADA NA BAIXA RENDA POR MEIO DE PARCERIAS [CR2 vs. conjunto de empresas]: Empresa que migrou para a baixa renda e novos mercados por meio de parceria apresentou margem líquida abaixo da média do conjunto de empresas;

6. EMPREGO DE DIVERSOS MODELOS DE NEGÓCIOS COMO ESTRATÉGIA DE DIVERSIFICAÇÃO [Cyrela vs. conjunto] A empresa que fez uso de diversos modelos de negócios pra a expansão de produtos e mercados, e migrou igualmente para o segmento de baixa renda, apresentou tendência de decréscimo nos indicadores ao longo do período;

A tabela abaixo apresenta os indicadores de desempenho destes agrupamentos de empresas em relação ao conjunto do mercado. Em seguida, serão discutidas as possíveis causas para as diferenças de desempenho. 
Tabela 26 - Evolução do indicador margem líquida por categoria de estrategia

\begin{tabular}{|c|c|c|c|c|}
\hline \multirow[t]{2}{*}{ ESTRATÉGIA } & \multirow[t]{2}{*}{ EMPRESA } & $\begin{array}{l}\text { MARGEM LÍQUIDA } \\
\text { Período 2006-2010 }\end{array}$ & $\begin{array}{l}\text { MARGEM LÍQUIDA } \\
\text { Ano } 2006\end{array}$ & $\begin{array}{c}\text { DIFERENÇA } 2010 \text { - } \\
2006 / 07\end{array}$ \\
\hline & & \multicolumn{3}{|c|}{ [pontos percentuais em relação ao conjunto do mercado] } \\
\hline CONCENTRAÇÃO DE PRODUTO & MRV e Rodobens & 4,1 & $-6,0$ & 10,1 \\
\hline DIVERSIFICAÇÃO GEOGRÁFICA & $\begin{array}{l}\text { PDG, Cyrela, Gafisa, } \\
\text { Rossi }\end{array}$ & $-0,9$ & $-6,0$ & 5,1 \\
\hline $\begin{array}{l}\text { MODELO DE CONCENTRAÇÃO DE PRODUTOS E } \\
\text { DIVERSIFICAÇÃO GEOGRÁFICA }\end{array}$ & MRV & 5,9 & $-2,8$ & 8,8 \\
\hline $\begin{array}{l}\text { MODELO DE CONCENTRAÇÃO GEOGRÁFICA E } \\
\text { DOMINÂNCIA DE PRODUTOS }\end{array}$ & Eztec & 14,5 & $-12,1$ & 26,6 \\
\hline AQUISIÇÕES PARA ENTRADA NA BAIXA RENDA & PDG & $-0,89$ & $-12,1$ & 11,2 \\
\hline $\begin{array}{l}\text { DESENVOLVIMENTO PRÓPRIO PARA ENTRADA } \\
\text { NA BAIXA RENDA }\end{array}$ & $\begin{array}{l}\text { Rossi e } \\
\text { Brookfield/Brascan }\end{array}$ & $-3,1$ & $-4,5$ & 1,4 \\
\hline PARCERIAS PARA ENTRADA NA BAIXA RENDA & CR2 & $-4,7$ & $-2,8$ & $-1,9$ \\
\hline $\begin{array}{l}\text { DIVERSOS MODELOS DE NEGÓCIOS COMO } \\
\text { ESTRATÉGIA DE DIVERSIFICAÇÃOO }\end{array}$ & Cyrela & 1,0 & 6,5 & $-5,5$ \\
\hline
\end{tabular}

Fonte: Elaboração do autor

\subsection{Interpretação dos resultados}

Os pontos [1] e [2] permitem destacar dois modelos de empresas quanto a diversificação do portfólio de produtos e mercados, que apresentam desempenho superior e crescente em relação ao conjunto de empresas do setor.

O modelo [1] trata da empresa com concentração de produtos na baixa renda e diversificação geográfica, e o modelo [2] da empresa de concentração geográfica (em nível municipal) e dominância de produtos na média renda.

Ambas as empresas são as que apresentam menores índices de diversificação em suas respectivas especialidades.

$\mathrm{O}$ autor interpreta os resultados positivos de desempenho em margem líquida a partir do referencial teórico exposto no início da presente dissertação, em que as especializações em produtos são capazes de conferir às empresas competência na formatação e produção destes.

A formatação, que exige competência de mercado para materializar os anseios do público alvo em atributos, tem sua importância na gestão de custos durante 
a fase de produção, uma vez que a racionalidade no projeto impacta no processo construtivo do empreendimento.

A competência da produção envolve racionalidade nos processos construtivos, controle de custos, gestão da obra e, sobretudo na baixa renda, aquisição de terrenos adequados, com preço, localização e características físicas que permitam o desenvolvimento de empreendimentos com inserção no mercado alvo e no patamar de qualidade do investimento almejado.

As empresas que se especializam em produtos se aproveitam da curva de aprendizado e experiência a cada empreendimento realizado, cuja maior capacidade de absorção dos aprendizados daí derivados em relação às empresas diversificadas por produtos [3 - PDG], as fazem produzir o próximo empreendimento mais competitivo e rentável que o anterior.

Uma característica comum às duas empresas é a construção própria. A MRV na baixa renda e a Eztec no segmento de média renda, que devem conferir às empresas maior capacidade de navegar na curva do aprendizado, e sobretudo garantir o controle de custos e qualidade do produto, que aqui se refere à qualidade física relacionada ao entregável, que se refletirá na qualidade do investimentos a partir de empreendimentos com maior capacidade de geração de riqueza.

Cabe a comparação do modelo da empresa CR2 com o modelo aqui discutido. A empresa igualmente possui concentração de produtos e, ao contrário da MRV e Eztec, não possui construção própria, trabalhando com parceiros no empreendimento ou com a terceirização.

Neste caso, nota-se que a empresa pode até se aproveitar de aprendizados a cada empreendimento realizado. No entanto, provavelmente serão mais relacionados à competência de mercado, da inserção do produto, do que de gestão da obra e controle de custos do empreendimento. Ao longo do período, a empresa intensificou sua atuação na baixa renda, e não só obteve média de 
margem líquida inferior ao conjunto de empresas, mas apresentou também decréscimo de sua distância à média das demais empresas.

Convém ressaltar que o desempenho superior de ambas as empresas, MRV e Eztec, deram-se num período de intenso crescimento do setor. Ao contrário da empresa CR2, ambas possuem menos flexibilidade, uma vez que possuem estruturas próprias de engenharia e construção especializadas num determinado segmento. Assim, o modelo de incorporação pura e o uso da terceirização e parcerias em empreendimento pode conferir a CR2 melhores resultados em momentos de desaquecimento e rupturas de demanda.

O item [4] destaca o uso de diferentes modelos de negócios para entrada nos segmentos de baixa renda.

Enquanto a empresa PDG cresceu e expandiu produtos por meio de aquisições, as empresas Rossi e Brookfield adotaram a estratégia de desenvolvimento próprio. Verificou-se que a PDG apresentou média de desempenho e variação de ambos os indicadores maior do que o grupo da Rossi e Brookfield.

$\mathrm{O}$ autor presume que o modelo de aquisição conferiu à PDG maior velocidade na aquisição das competências para atuação no segmento de baixa renda em relação ao modelo de desenvolvimento próprio.

Presume-se que a aquisição traga consigo a capacidade intrínseca de prover à empresa adquirente as competências de produtos e mercados em velocidade muito maior. $\mathrm{O}$ modelo permite que a empresa adquirente embarque rapidamente na curva de aprendizado da empresa adquirida. Porém, o modelo confere à empresa adquirente o desafio de gestão em nível organizacional, uma vez que a aquisição implica em trazer para companhia pessoas, processos e cultura diferentes. Em contrapartida, o desafio de gestão não é problema para o modelo de desenvolvimento próprio, cujo desafio passa a ser unicamente desenvolver competências de produtos e mercados. 
Portanto, escolher entre aquisição e desenvolvimento próprio implica em balizar os desafios de eficiência em nível de empreendimento e empresa, antagônicos conforme o modelo de negócio. Enquanto as aquisições podem propiciar para a empresa maior velocidade de entrada em um novo mercado, traz consigo o desafio da gestão das duas empresas. O modelo de desenvolvimento próprio, o contrário. Logicamente podem existir situações limites, nas quais a aquisição é tão pequena a ponto de trazer recursos valiosos com o mínimo de impacto de gestão, e, por outro lado, a empresa pode optar por um crescimento a partir da contratação de novos profissionais, cuja escala naturalmente agregará desafios organizacionais.

Por fim, as empresas Rossi e Brookfield apresentaram diferença de comportamento entre si. Enquanto a primeira apresentou crescimento gradual de margem e retorno sobre o patrimônio líquido ao longo do período, a última apresentou decréscimo de margens.

A Brookfield, ao contrário da Rossi, adquiriu novas empresas para expansão geográfica. Num primeiro momento fundiu-se com a Company, e num segundo adquiriu a MB engenharia para entrada no centro-oeste brasileiro. A Rossi optou pelos modelos de expansão por meio de parcerias e abertura de escritórios regionais. Os processos de fusão e aquisição da empresa Brookfield a possibilitou que ela entrasse rapidamente em novos mercados. Presume-se, no entanto, que a estratégia a tenha conferido ineficiência em nível de empresa, devido ao rápido crescimento e dificuldade em gerir e unificar as novas empresas.

A empresa Cyrela apresentou diversos modelos de negócios para a entrada em novas geografias e produtos. Fez uso de parcerias, joint venture e aquisições para a entrada no segmento de baixa renda, junto com o desenvolvimento próprio de competências, por meio de construtora própria (Living).

A empresa apresentou capacidade de transformar receita em resultado acima da média do conjunto de empresas, no entanto, apresentou decréscimo no período em relação às demais companhias. A análise dos indicadores a partir do quadro 
resumo, disponível no item 8.1.3, demonstra que a empresa não tem perdido margem em relação à média devido ao ganho de desempenho por parte das demais empresas, mas sim porque os seus próprios indicadores de resultado têm decrescido.

O autor presume que os diversos modelos de negócios utilizados pela empresa para a entrada nos segmento de baixa renda e novas geografias, devido à inerente dificuldade de gerir os parceiros e os modelos, incorreram em ineficiências em nível de empreendimentos.

Por fim, os resultados acima apresentados não permitem conclusões seguras quanto às relações entre as estratégias adotadas e ao desempenho econômico das organizações, no entanto, permitem as seguintes constatações que podem ser importantes para futuras investigações:

1. Estratégia de concentração geográfica e de produtos: as duas empresas de maior concentração (MRV e Eztec) apresentaram indicadores de desempenho acima do conjunto do mercado. A interpretação é que a especialização e o não afastamento de suas competências originais gera maior capacidade de formatar e construir empreendimentos.

2. Expansão de produto por meio de aquisições: a estratégia permite que a empresa adquira as competências necessárias para o novo negócio mais rapidamente do que as opções do desenvolvimento próprio ou outros tipos de alianças. As empresas que adotaram esta estratégia(PDG e CCDI) não se posicionaram como as empresas de melhor desempenho, porém tiveram evolução positiva nos indicadores ao longo do período em relação ao conjunto do mercado.

3. Entrada na baixa renda por meio do desenvolvimento próprio de competências: as empresas que adotaram esta estratégia tampouco Figuraram nas organizações de melhor desempenho, porém igualmente às empresas que expandiram produtos por meio de aquisições, melhoraram (em menor nível) o desempenho relativo ao conjunto do 
mercado ao longo do período. A interpretação é que o desenvolvimento interno de competências exige maior tempo e número de recursos para que a empresa adquira os conhecimentos necessários para um bom desempenho no negócio da baixa renda, podendo haver, portanto, uma penalização em curto prazo, o que não a descarta, porém, como uma estratégia de longo prazo.

4. Expansão de produtos e geografias por meio de parcerias: opção da maioria das empresas, devido muito provavelmente à maior flexibilidade, rapidez de acesso ao novo negócio e baixo custo de saída em relação às outras estratégias. As empresas que adotaram a opção se mostraram, em sua maioria, num posicionamento relativo ao conjunto do mercado de médio a baixo. A interpretação é que as parcerias conferiram às empresas maior dificuldade na formatação e na execução dos empreendimentos a distância, e na gestão e financiamento dos parceiros.

Tanto a concentração em produtos como os modelos de aquisição e desenvolvimento de competências próprias agregam às empresas vantagens competitivas de produtos, uma vez que estas detêm o conhecimento e controle da produção e formatação do empreendimento, conforme sugerem os resultados. No entanto, os modelos propiciam menos flexibilidade em relação às empresas que entram em novos mercados por meio de alianças menos intensas, tais como as parcerias e joint ventures, cujos custos de saída de um mercado ou negócio são menores.

O limite máximo de flexibilidade de uma empresa de Real Estate está nas empresas de incorporação pura e que terceirizam as atividades de construção ou as fazem com parceiros. Nesta pesquisa, identificou-se apenas uma empresa na amostra com esta característica, cujo desempenho relativo foi inferior ao conjunto do mercado. 
Este resultado não significa dizer que flexibilidade gera menor desempenho, mas sim abre a discussão para as decisões de nível estratégico dos gestores destas organizações, que de certa maneira são orientadas sempre para o atendimento do melhor desempenho, que em curto prazo pode significar alta especialização e menos flexibilidade, e no longo prazo diversificação e alta flexibilidade, havendo, portanto, a busca por um ponto ótimo que possa fazer com que a empresa gere hoje e futuramente os resultados esperados.

Neste sentido, pode ser razoável dizer que uma empresa mais flexível, que busca sempre as melhores oportunidades por meio de competências externas, firmando parcerias e alianças com empresas e fornecedores especializados, possa apresentar menor capacidade de geração de desempenho quando em mercados de maior estabilidade ${ }^{18}$ quanto à demanda por um produto; no entanto, em momentos de rupturas e alterações de mercado, as empresas mais flexíveis podem possuir maior capacidade de geração ou mesmo manutenção de desempenho em relação às empresas especializadas, que podem se ver numa situação de mudança, cuja menor flexibilidade pode acarretar maiores custos de saída e menor velocidade, tanto na percepção como na entrada no novo mercado, o que refletirá no desempenho da organização.

\footnotetext{
${ }^{18}$ A estabilidade aqui se refere a clara percepção pela demanda de um determinado produto, e não estagnação de mercado, crescimento nulo. Convém ressaltar também que a presente pesquisa analisou as empresas durante um período de elevado crescimento e clara percepção por uma demanda de empreendimentos destinados aos segmentos de menor poder aquisitivo.
} 


\section{CONSIDERAÇÕES FINAIS}

A pesquisa teve como objetivo analisar o quanto que o nível de diversificação e dos modelos de negócios para expansão de produtos e mercados influenciou no desempenho econômico das empresas de Real Estate.

Para atendimento do objetivo, foram identificadas e levantadas informações dos lançamentos de vinte e uma empresas de Real Estate listadas no segmento Novo Mercado da BM\&FBovespa.

Neste período, verificou-se que todas as empresas passaram por um intenso ciclo de crescimento e alteração de porte e estratégia, passando a acessar novas geografias e segmentos de renda. Em cinco anos, as organizações cresceram, aproximadamente, sete vezes em valor geral de venda dos lançamentos, trezes vezes no número de unidades imobiliárias, doze vezes em patrimônio líquido, nove vezes no número de cidades com operação e dezesseis vezes na oferta de unidades para os segmentos econômico e popular.

O hiato entre a situação do início do ano de 2005 e final do ano de 2010 só foi possível por que as empresas conseguiram captar recursos suficientes via emissão primária de ações e fizeram uso intensivo de alianças estratégicas, com destaque para as parcerias com empresas locais.

As parcerias foram utilizadas em sua maioria para acessar novas regiões geográficas. Para o acesso aos segmentos de menor renda, as estratégias de aquisição e desenvolvimento próprio de competências foram as mais utilizadas.

A pesquisa identificou que, do ponto de vista da diversificação de produtos e geográfica, e dos modelos de negócios empregados no período para a expansão e diversificação do portfólio de lançamentos, todas as empresas são diferentes entre si, e apresentaram, igualmente, diferenças de desempenho e comportamento deste no período. 
O modelo de concentração de produtos mostrou-se de desempenho superior. As empresas que optaram por entrar na baixa renda por meio de aquisições tiveram aumento nos indicadores de desempenho ao longo do período. As empresas que optaram por desenvolver competências próprias para entrada no segmento de baixa renda se beneficiaram no período, no entanto, em ritmo menor. Já as organizações que optaram por parcerias para a expansão para novos segmentos e mercados apresentaram, em sua maioria, desempenho inferior relativamente ao conjunto do mercado.

Os resultados, no entanto, não são absolutos e tampouco foram suficientes para identificar quais estratégias são melhores que as outras, mas foram utilizados para a constatação, discussão e interpretação dos motivos pelos quais determinadas empresas apresentaram desempenho diferentes entre si, e o quanto que as estratégias adotadas possam ter influenciado nestes.

Importante destacar a busca pelo desempenho e pela flexibilidade, cujo binômio se traduz em decisões nas organizações que buscam a geração de desempenho em curto e longo prazo, e podem exigir muitas vezes decisões antagônicas em termos de especialização, modelos de negócios e consequentemente no nível de flexibilidade da organização.

Convém ressaltar que os resultados obtidos na pesquisa devem ser interpretados segundo diversas ressalvas, conforme abordado no capítulo de metodologia. Primeiro, por que o desempenho das empresas de Real Estate não sofre influência apenas pelas variáveis aqui analisadas; as estratégias de vendas, de marketing, de produção, de gestão, e outras são capazes de também influenciar no desempenho destas organizações. Em segundo lugar, pelas aproximações e simplificações realizadas com o objetivo de classificar as empresas, segundo o nível de diversificação e os modelos de negócios. Em terceiro, por que existe um atraso entre as decisões da organizações e a efetivação do desempenho provocado por estas. Assim, os lançamentos realizados nos anos de 2009 e 2010, expressivos em volume de receita esperada de venda, terão os desempenhos refletidos apenas nos balanços dos anos subsequentes. 
Por fim, tendo em vista que o presente trabalho analisou as estratégias e os modelos de negócios aplicados numa fase de intenso crescimento de mercado, e, portanto, uma abordagem da estratégia de entrada em novos mercados, e não de operação, o autor recomenda para futuras pesquisas a continuidade desta investigação, com o objetivo de verificar os modelos de negócios em mercados em situações de menor crescimento, e consequentemente, investigar sobre a influência do nível de flexibilidade em períodos de maior prazo e diferentes situações de mercado.

O autor também sugere que as interpretações aqui formuladas para as diferenças de desempenho sejam melhor estudadas e compreendidas. Isso seria possível por meio do estudo de caso de empresas específicas, com o objetivo de entender as decisões num nível de detalhe maior. Recomenda-se analisar como foram firmadas as parcerias entre as empresas de maior porte e as empresas locais, os contratos, as condições, responsabilidades e gestão das parcerias. Recomenda-se, igualmente, analisar o processo das empresas que optaram pela diversificação por meio de aquisições e desenvolvimento próprio de competências, com o objetivo de identificar melhor as dificuldades e vantagens inerentes a cada estratégia. 


\section{REFERÊNCIAS}

ANSOFF, IGOR H. Estratégia Empresarial. São Paulo: Editora McGrawHill do Brasil, 1977.

AVELAR, A., MONTEIRO, A. Alianças Estratégicas na construção civil: o subsetor de edificações na cidade de Salvador - Bahia. IV Simpósio de Excelência em Gestão e Tecnologia. Resende, 2007.

BARNEY, J.B. Firm resources and sustained competitive advantage. Journal of Management, v.1, p. 99-120, 1991.

BATALHA-VASCONCELOS, D. Alianças estratégicas e o mercado imobiliário. VIII Seminário Internacional da Lares - Latin American Real Estate Society, São Paulo, 2008.

CCDI. Prospecto definitivo de distribuição pública primária e secundária de ações ordinárias da Camargo Corrêa Desenvolvimento Imobiliário. Disponível em: <http://www.ccdi.com.br/ri>.2007.

CR2. Prospecto definitivo de distribuição pública primária de ações ordinárias da CR2 Empreendimentos Imobiliários. Disponível em $<$ http://www.cr2.com.br/ri> 2007.

CR2b. Relatório de resultados e informações financeiras suplementares do exercício 2007 da CR2 Empreendimentos Imobiliários. Disponível em $<$ http://www.cr2.com.br/ri> 2007.

CR2. Relatório de resultados e informações financeiras suplementares do exercício 2006 da CR2 Empreendimentos Imobiliários. Disponível em $<$ http://www.cr2.com.br/ri. 2006> 2006.

CYRELA. Prospecto definitivo de distribuição pública primária e secundária de ações ordinárias da Cyrela Brazil Realty. Disponível em: $<$ http://www.cyrela.com.br/ri> 2006

EUA. Horizontal mergers Guidelines. U.S. Department of justice and the Federal Trade Comission. Disponível em $<$ http://www.justice.gov/atr/public/guidelines/hmg-2010.html> 2010

EZTEC. Transcrição da teleconferência dos resultados do exercício de 2008. Disponível em: <http://www.eztec.com.br/ri> 2008.

GAFISA. Relatório de resultados e informações financeiras suplementares do exercício 2006 da Gafisa. Disponível em: <http://www.gafisa.com.br/ri> 2006. 
DAS, T. K., TENG, B. Risk types and inter-firm alliance structures. Journal of Management Studies, v. 33:6, p. 827-843, 1996.

DE WIT, I., International Diversification Strategies for Direct Real Estate (June 9, 2009). Journal of Real Estate Finance and Economics, v. 41, n. 4, 2009.

MRV. Prospecto definitivo de distribuição pública primária de ações ordinárias da MRV Engenharia e Participações. Disponível em: $<$ http://www.mrv.com.br/ri> 2007.

HAMEL, G. Competition for competence and inter-partner learning with international strategic alliances. Strategic Management Journal, v. 12, p. 83103, 1991.

HAUSMAN, J. SIDAK, G. Evaluating market power using competitive benchmark prices instead of the herfindahl-hirschman index. Antitrust law Journal, n. 2., p. 387-407, 2007.

HELBOR. Prospecto definitivo de distribuição pública primária de ações ordinárias da Helbor Empreendimentos. Disponível em: $<$ http://www.helbor.com.br/ri> 2007.

HEWLETT, C. KAUFMANN, G. Strategy for Real Estate Companies. Washington. Urban land Institute, 2008.

JHSF. Relatório de resultados e informações financeiras suplementares do exercício 2010 da JHSF. Disponível em <http://www.jhsf.com.br/ri> 2010

PDG. Prospecto definitivo de distribuição pública primária de ações ordinárias da PDG Realty. Disponível em: <http://www.pdg.com.br/ri> 2007.

PALMA, A.J.C. Manual de direito empresarial. São Paulo: Editora Quartier Latin do Brasil, 2006.

PRAHALAD, C. K.; HAMEL, G. The Core Competence of the Corporation. Harvard Business Review, p. 3-15, May/June, 1990.

ROSSI. Relatório de resultados e informações financeiras suplementares do exercício 2009. Disponível em: <http://www.rossi.com.br/ri> 2009.

KOGUT, B. The stability of joint ventures: reciprocity and competitive rivalty. Journal of Industrial Economics, v. 38, p.183-198, 1989.

KUMAR, M. The value from acquiring and divesting a joint venture: a real options approach. Strategic Management Journal, v. 26, p. 321-331, 2005.

LYNCH, R.P. Building Alliances to Penetrate European Markets. Journal of Business Strategy, vl.2, p. 4-8, 1990. 
LORANGE, P.; ROOS, J. Strategic alliances: formation, implementation and evolution. Malden: Blackwell, 1993.

MATARAZZO, D. Análise Financeira de Balanços - Abordagem Gerencial. São Paulo: Editora Atlas, 2010.

PALEPU, K. Diversification strategy, profit performance and entropy measure. Strategic Management Journal, v. 6, p. 239-255, 1985.

PRAHALAD, C.K.; HAMEL G. The Core Competence of the Corporation. Harvard Business Review, v. 68, n. 3, p. 79-91, 1990.

PITTS, R. A.; HOPKINS, H.D. Firm Diversity: Conceptualization and Measurement. Academy of Management Review, v. 7, n. 4, p. 620-629, 1982.

ROCHA LIMA, J. Política empresarial e diretrizes de ação. Boletim Técnico. BT/PCC/126. Escola Politécnica da Universidade de São Paulo, 1994.

ROCHA LIMA, J. Habitação para baixa renda: os empreendimentos funcionam? Carta do Núcleo de Real Estate, Escola Politécnica da Universidade de São Paulo, 2009.

RUMELT, R. Strategy, structure and economic performance. Cambridge: Harvard University Press, 1974.

VASSOLO, R. S., ANAND, J., FOLTA, T.B. Non-additivity in portfolios of exploration activities: A real options-based analysis of equity alliances in biotechnology. Strategic Management Journal, v. 25, p.1045-1061, 2004.

WASSMER, U., DUSSAGE, P. Value Creation in Alliance Portfolios: The Benefits and Costs of Network Resource Interdependencies. European Management Review, v. 8, p. 47-64, 2011.

WILLIAMSON, O.E. The Mechanisms of Governance. New York: Oxford University Press, 1996.

WRIGLEY, L. Divisional autonomy and diversification. Doctoral dissertation, Harvard Business School. Cambridge, MA, 1970. 
APÊNDICES 


\section{Apêndice A - Lançamentos por Município no período 2006 a 2010}

[Em volume estimado de venda em R \$ milhão da base]

\begin{tabular}{|c|c|c|c|c|c|c|}
\hline CIDADE-UF & 2006 & 2007 & 2008 & 2009 & 2010 & TOTAL \\
\hline São Paulo-SP & 6.136 & 10.647 & 9.868 & 6.841 & 11.570 & 45.061 \\
\hline Rio de Janeiro-RJ & 2.316 & 3.802 & 2.969 & 1.755 & 2.850 & 13.691 \\
\hline Campinas-SP & 252 & 774 & 1.086 & 568 & 2.483 & 5.164 \\
\hline Salvador-BA & 215 & 907 & 1.511 & 623 & 936 & 4.192 \\
\hline Curitiba-PR & 100 & 449 & 767 & 606 & 2.147 & 4.069 \\
\hline Porto Alegre-RS & 268 & 587 & 564 & 1.146 & 1.230 & 3.795 \\
\hline Belo Horizonte-MG & 89 & 589 & 1.048 & 785 & 1.217 & 3.729 \\
\hline Goiânia-GO & 44 & 357 & 477 & 825 & 1.710 & 3.413 \\
\hline Brasília-DF & & 205 & 703 & 742 & 1.709 & 3.359 \\
\hline São Bernardo do Campo-SP & 82 & 1.130 & 676 & 270 & 126 & 2.284 \\
\hline Guarulhos-SP & 99 & 449 & 465 & 699 & 489 & 2.201 \\
\hline Belém-PA & 16 & 208 & 300 & 405 & 970 & 1.900 \\
\hline Santos-SP & 209 & 818 & 304 & 122 & 403 & 1.857 \\
\hline São José dos Campos-SP & 87 & 404 & 598 & 366 & 388 & 1.843 \\
\hline Barueri-SP & & 556 & 482 & 317 & 340 & 1.696 \\
\hline Sorocaba-SP & 23 & 880 & 551 & 11 & 131 & 1.596 \\
\hline São Luís-MA & & 258 & 257 & 415 & 559 & 1.489 \\
\hline Manaus-AM & 15 & 156 & 85 & 335 & 734 & 1.324 \\
\hline Ribeirão Preto-SP & 16 & 292 & 522 & 157 & 192 & 1.178 \\
\hline Santo André-SP & 149 & 248 & 312 & 156 & 207 & 1.072 \\
\hline Jundiaí-SP & 22 & 68 & 448 & 125 & 385 & 1.049 \\
\hline Fortaleza-CE & 38 & 4 & 386 & 204 & 264 & 895 \\
\hline Niterói-RJ & 105 & 103 & 323 & 337 & & 868 \\
\hline Osasco-SP & 44 & 167 & 371 & 76 & 153 & 810 \\
\hline Vitória-ES & 21 & 228 & 136 & 92 & 285 & 762 \\
\hline Campo Grande-MS & & & & 304 & 428 & 732 \\
\hline Cuiabá-MT & & & 13 & 327 & 389 & 729 \\
\hline São José do Rio Preto-SP & 27 & 173 & 249 & 128 & 135 & 712 \\
\hline Serra-ES & 10 & 107 & 254 & 194 & 126 & 690 \\
\hline Natal-RN & & & 69 & 312 & 303 & 684 \\
\hline São Caetano do Sul-SP & & 434 & 52 & 74 & 98 & 658 \\
\hline Mogi das Cruzes-SP & 12 & 138 & 270 & 115 & 110 & 645 \\
\hline São Gonçalo-RJ & & 531 & 43 & 29 & & 604 \\
\hline Recife-PE & & 74 & 166 & 170 & 173 & 584 \\
\hline Taboão da Serra-SP & & 407 & 53 & & & 460 \\
\hline Florianópolis-SC & & 9 & 144 & 114 & 187 & 454 \\
\hline Nova Iguaçu-RJ & & 177 & 87 & 72 & 111 & 446 \\
\hline Cajamar-SP & & & 61 & 327 & 47 & 435 \\
\hline Cotia-SP & 2 & 51 & 116 & 93 & 161 & 423 \\
\hline Nova Lima-MG & 83 & 30 & 175 & 42 & 54 & 383 \\
\hline Americana-SP & 2 & 110 & 140 & 4 & 86 & 343 \\
\hline Joinville-SC & 5 & 43 & 163 & 69 & 52 & 331 \\
\hline Feira de Santana-BA & & 172 & 91 & 12 & 49 & 323 \\
\hline Campos dos Goytacazes-RJ & & & 213 & 64 & 46 & 323 \\
\hline
\end{tabular}




\begin{tabular}{|c|c|c|c|c|c|c|}
\hline CIDADE-UF & 2006 & 2007 & 2008 & 2009 & 2010 & TOTAL \\
\hline Lauro de Freitas-BA & & 24 & 61 & 98 & 140 & 323 \\
\hline Contagem-MG & 18 & 97 & 175 & & 18 & 309 \\
\hline Suzano-SP & & 36 & 17 & 108 & 143 & 304 \\
\hline Londrina-PR & 5 & 40 & 218 & 5 & 27 & 296 \\
\hline Sumaré-SP & 71 & & 149 & 40 & 31 & 293 \\
\hline Juiz de Fora-MG & & & 217 & 35 & 26 & 278 \\
\hline Guarujá-SP & 41 & 59 & 114 & 60 & & 273 \\
\hline Porto Feliz-SP & & & & & 271 & 271 \\
\hline Ananindeua-PA & & & 112 & 56 & 99 & 267 \\
\hline Uberlândia-MG & 6 & 6 & 112 & 56 & 84 & 265 \\
\hline Marília-SP & 2 & & 114 & 101 & 33 & 250 \\
\hline Taubaté-SP & 3 & 135 & 99 & & & 237 \\
\hline Diadema-SP & & 46 & 26 & & 161 & 233 \\
\hline Canoas-RS & & & 23 & 76 & 117 & 216 \\
\hline Caxias do Sul-RS & & & 164 & 38 & & 202 \\
\hline Bertioga-SP & 111 & 84 & & & & 195 \\
\hline Mangaratiba-RJ & & & & 90 & 103 & 193 \\
\hline São José-SC & & 153 & & & 38 & 190 \\
\hline Piracicaba-SP & 4 & 34 & 130 & 14 & & 182 \\
\hline Belford Roxo-RJ & & 77 & 18 & 59 & 28 & 181 \\
\hline Palhoça-SC & & & 78 & 26 & 72 & 176 \\
\hline Camaçari-BA & & 172 & & & & 172 \\
\hline Duque de caxias-RJ & & 152 & 18 & & & 170 \\
\hline São Carlos-SC & & 20 & & & 139 & 158 \\
\hline Maceió-AL & & 64 & 65 & 16 & 12 & 157 \\
\hline Cascavel-PR & & & 57 & 60 & 39 & 157 \\
\hline Carapicuíba-SP & & & & & 153 & 153 \\
\hline Hortolândia-SP & & & 20 & 73 & 56 & 150 \\
\hline Betim-MG & & 49 & 37 & & 62 & 148 \\
\hline Araçatuba-SP & & & & 89 & 53 & 142 \\
\hline Porto Velho-RO & & & 67 & 20 & 54 & 141 \\
\hline Jaboatão dos Guararapes-PE & & & 97 & & 35 & 132 \\
\hline Mauá-SP & 4 & 40 & 78 & & & 122 \\
\hline Colombo-PR & & & & 119 & & 119 \\
\hline Novo Hamburgo-RS & & & 83 & 31 & & 114 \\
\hline São Vicente-SP & & 84 & 15 & 14 & & 113 \\
\hline Bauru-SP & 4 & & 32 & 48 & 29 & 112 \\
\hline Franca-SP & 4 & 55 & 51 & & & 109 \\
\hline Jaguariúna-SP & & & 48 & & 60 & 108 \\
\hline Uberaba-MG & 3 & 4 & 66 & 9 & 24 & 105 \\
\hline Macaé-RJ & & & 31 & & 71 & 102 \\
\hline Vila Velha-ES & & & 97 & & & 97 \\
\hline Ferraz de Vasconcelos-SP & & 12 & 74 & 9 & & 95 \\
\hline Montes Claros-MG & & & & 39 & 49 & 88 \\
\hline
\end{tabular}

Página 2/4 


\begin{tabular}{|c|c|c|c|c|c|c|}
\hline CIDADE-UF & 2006 & 2007 & 2008 & 2009 & 2010 & TOTAL \\
\hline Santa Luzia-MG & & 85 & & & & 85 \\
\hline Aparecida de Goiânia-GO & & 38 & 30 & 17 & & 84 \\
\hline Santa Bárbara d'Oeste-SP & 2 & & & & 80 & 82 \\
\hline Araraquara-SP & 2 & 6 & 48 & 25 & & 82 \\
\hline São Leopoldo-RS & & & 42 & & 35 & 76 \\
\hline Governador Valadares-MG & & 18 & 38 & 17 & & 73 \\
\hline Patos de Minas-MG & & & 12 & 28 & 33 & 73 \\
\hline Itajaí-SC & & & & & 70 & 70 \\
\hline Ponta Grossa-PR & & & 24 & 41 & 4 & 70 \\
\hline Volta Redonda-RJ & & 43 & 26 & & & 69 \\
\hline Anápolis-GO & & 9 & 59 & & & 69 \\
\hline Aracaju-SE & & & 30 & & 38 & 68 \\
\hline Pelotas-RS & & & 12 & 22 & 31 & 65 \\
\hline Santa Maria-RS & & & & 32 & 34 & 65 \\
\hline Itaquaquecetuba-SP & & 20 & 22 & & 22 & 65 \\
\hline Limeira-SP & & & 32 & 5 & 26 & 63 \\
\hline João Pessoa-PB & & & 43 & & 19 & 62 \\
\hline Aquiraz-CE & & & & & 61 & 61 \\
\hline Várzea Grande-MT & & 60 & & & & 60 \\
\hline Taquara-RS & & & & & 59 & 59 \\
\hline Maringá-PR & 3 & 20 & 34 & & & 58 \\
\hline São Carlos-SP & 2 & & 39 & 16 & & 57 \\
\hline Resende-RJ & & 54 & & & & 54 \\
\hline Praia Grande-SP & & 52 & & & & 52 \\
\hline Rondonópolis-MT & & & 31 & & 18 & 49 \\
\hline Itapetininga-SP & & & 11 & 10 & 27 & 48 \\
\hline Indaiatuba-SP & & 3 & 45 & & & 47 \\
\hline Valinhos-SP & & 25 & & 22 & & 47 \\
\hline Poá-SP & 10 & 34 & & & & 45 \\
\hline Lages-SC & & & & 11 & 32 & 43 \\
\hline Paço do Lumiar-MA & & & & & 42 & 42 \\
\hline Alvorada-RS & & & 4 & 15 & 20 & 40 \\
\hline Guarapuava-PR & & & & & 38 & 38 \\
\hline Santana de Parnaíba-SP & 35 & & & & & 35 \\
\hline Ourinhos-SP & & & & & 35 & 35 \\
\hline Jandira-SP & & 35 & & & & 35 \\
\hline São Sebastião-SP & & 32 & & & & 32 \\
\hline Itu-SP & & & 32 & & & 32 \\
\hline Foz do Iguaçu-PR & & & & 21 & 10 & 31 \\
\hline Ribeirão das Neves-MG & & 9 & & 21 & & 31 \\
\hline Rio Verde-GO & & & & & 29 & 29 \\
\hline Santa Luzia-MA & & & & & 27 & 27 \\
\hline Jacareí-SP & 10 & & 17 & & & 27 \\
\hline Cabo Frio-RJ & & & 27 & & & 27 \\
\hline
\end{tabular}

Página 3/4 


\section{CIDADE-UF}

2006

Novo Gama-GO

Cidade Ocidental-GO

Pedreira-SP

Pacatuba-CE

Sete Lagoas-MG

Vitória da Conquista-BA

Eldorado do Sul-RS

Gravataí-RS

Santa Cruz do Sul-RS

Paulínia-SP

Esteio-RS

Votorantim-SP

Valença-BA

Cachoeirinha-RS

Barbacena-MG

Valparaíso de goiás-GO

Arujá-SP

Itapevi-SP

Cosmópolis-SP

Alto Taquari-MT

Águas Lindas de Goiás-GO
27

26

26

24

24

23

22

22

21

11

1

20

18

8

18

10

18

17

16

14

16

14

14

14

13

13

7

5

Página 4/4 
Apêndice B - Lançamentos por Mesoregião no período 2006 a 2010

[Em volume estimado de venda em R $\$$ milhão da base]

\begin{tabular}{|c|c|c|c|c|c|c|}
\hline MESOREGIÃO & 2006 & 2007 & 2008 & 2009 & 2010 & TOTAL \\
\hline Total & 11.703 & 30.541 & 32.045 & 22.346 & 37.984 & 134.620 \\
\hline METROPOLITANA DE SAO PAULO & 6.935 & 15.560 & 13.389 & 9.280 & 14.185 & 59.349 \\
\hline METROPOLITANA DO RIO DE JANEIRO & 2.421 & 4.841 & 3.457 & 2.341 & 3.091 & 16.152 \\
\hline CAMPINAS & 329 & 912 & 1.522 & 708 & 2.820 & 6.290 \\
\hline METROPOLITANA DE BELO HORIZONTE & 190 & 859 & 1.435 & 848 & 1.375 & 4.708 \\
\hline METROPOLITANA DE SALVADOR & 215 & 1.103 & 1.572 & 721 & 1.076 & 4.688 \\
\hline METROPOLITANA DE PORTO ALEGRE & 268 & 587 & 734 & 1.300 & 1.491 & 4.380 \\
\hline METROPOLITANA DE CURITIBA & 100 & 449 & 767 & 725 & 2.147 & 4.188 \\
\hline CENTRO GOIANO & 44 & 404 & 566 & 842 & 1.710 & 3.566 \\
\hline DISTRITO FEDERAL & & 205 & 703 & 742 & 1.709 & 3.359 \\
\hline MACRO METROPOLITANA PAULISTA & 45 & 949 & 1.039 & 146 & 787 & 2.966 \\
\hline METROPOLITANA DE BELEM & 16 & 208 & 412 & 461 & 1.069 & 2.167 \\
\hline VALE DO PARAIBA PAULISTA & 100 & 571 & 714 & 366 & 388 & 2.139 \\
\hline CENTRAL ESPIRITO-SANTENSE & 31 & 335 & 487 & 285 & 411 & 1.549 \\
\hline NORTE MARANHENSE & & 258 & 257 & 415 & 601 & 1.531 \\
\hline CENTRO AMAZONENSE & 15 & 156 & 85 & 335 & 734 & 1.324 \\
\hline RIBEIRAO PRETO & 19 & 347 & 573 & 157 & 192 & 1.287 \\
\hline METROPOLITANA DE FORTALEZA & 38 & 4 & 386 & 204 & 348 & 980 \\
\hline GRANDE FLORIANOPOLIS & & 162 & 222 & 140 & 297 & 821 \\
\hline CENTRO-SUL MATO-GROSSENSE & & 60 & 13 & 327 & 389 & 790 \\
\hline CENTRO NORTE DE MATO GROSSO DO SUL & & & & 304 & 428 & 732 \\
\hline METROPOLITANA DE RECIFE & & 74 & 263 & 170 & 209 & 716 \\
\hline SAO JOSE DO RIO PRETO & 27 & 173 & 249 & 128 & 135 & 712 \\
\hline LESTE POTIGUAR & & & 69 & 312 & 303 & 684 \\
\hline TRIANGULO MINEIRO/ALTO PARANAIBA & 10 & 10 & 190 & 93 & 141 & 443 \\
\hline NORTE FLUMINENSE & & & 244 & 64 & 117 & 425 \\
\hline NORTE CENTRAL PARANAENSE & 9 & 59 & 253 & 5 & 27 & 353 \\
\hline NORTE CATARINENSE & 5 & 43 & 163 & 69 & 52 & 331 \\
\hline CENTRO NORTE BAIANO & & 172 & 91 & 12 & 49 & 323 \\
\hline ZONA DA MATA & & & 217 & 35 & 26 & 278 \\
\hline MARILIA & 2 & & 114 & 101 & 33 & 250 \\
\hline PIRACICABA & 4 & 34 & 162 & 20 & 26 & 246 \\
\hline NORDESTE RIO-GRANDENSE & & & 164 & 38 & & 202 \\
\hline OESTE PARANAENSE & & & 57 & 82 & 49 & 188 \\
\hline OESTE CATARINENSE & & 20 & & & 139 & 158 \\
\hline LESTE ALAGOANO & & 64 & 65 & 16 & 12 & 157 \\
\hline ARACATUBA & & & & 89 & 53 & 142 \\
\hline MADEIRA-GUAPORE & & & 67 & 20 & 54 & 141 \\
\hline ARARAQUARA & 5 & 6 & 87 & 41 & & 139 \\
\hline SUL FLUMINENSE & & 97 & 26 & & & 123 \\
\hline BAURU & 4 & & 32 & 48 & 29 & 112 \\
\hline NORTE DE MINAS & & & & 39 & 49 & 88 \\
\hline LESTE GOIANO & & & 48 & 26 & & 74 \\
\hline VALE DO RIO DOCE & & 18 & 38 & 17 & & 73 \\
\hline VALE DO ITAJAI & & & & & 70 & 70 \\
\hline CENTRO ORIENTAL PARANAENSE & & & 24 & 41 & 4 & 70 \\
\hline LESTE SERGIPANO & & & 30 & & 38 & 68 \\
\hline SUDESTE RIO-GRANDENSE & & & 12 & 22 & 31 & 65 \\
\hline CENTRO OCIDENTAL RIO-GRANDENSE & & & & 32 & 34 & 65 \\
\hline MATA PARAIBANA & & & 43 & & 19 & 62 \\
\hline SUDESTE MATO-GROSSENSE & & & 31 & 7 & 18 & 56 \\
\hline ITAPETININGA & & & 11 & 10 & 27 & 48 \\
\hline SERRANA & & & & 11 & 32 & 43 \\
\hline CENTRO-SUL PARANAENSE & & & & & 38 & 38 \\
\hline ASSIS & & & & & 35 & 35 \\
\hline SUL GOIANO & & & & & 29 & 29 \\
\hline OESTE MARANHENSE & & & & & 27 & 27 \\
\hline BAIXADAS & & & 27 & & & 27 \\
\hline CENTRO SUL BAIANO & & & & & 22 & 22 \\
\hline CENTRO ORIENTAL RIO-GRANDENSE & & & 11 & & 10 & 21 \\
\hline SUL BAIANO & & 18 & & & & 18 \\
\hline CAMPO DAS VERTENTES & & & 17 & & & 17 \\
\hline Mesoregiões não identificadas & 873 & 1.782 & 907 & 150 & 802 & 4.514 \\
\hline
\end{tabular}


Apêndice C - Lançamentos por estados no período 2006 a 2010

[Em volume estimado de venda em R \$ milhão da base]

\begin{tabular}{|c|c|c|c|c|c|c|}
\hline ESTADO & 2006 & 2007 & 2008 & 2009 & 2010 & Total \\
\hline Total & 11.703 & 30.541 & 32.045 & 22.346 & 37.984 & 134.620 \\
\hline AL & & 76 & 65 & 16 & 12 & 169 \\
\hline AM & 15 & 156 & 85 & 335 & 734 & 1.324 \\
\hline BA & 215 & 1.294 & 1.663 & 733 & 1.147 & 5.051 \\
\hline CE & 38 & 4 & 386 & 204 & 348 & 980 \\
\hline DF & & 316 & 703 & 742 & 1.709 & 3.471 \\
\hline ES & 31 & 514 & 487 & 285 & 411 & 1.728 \\
\hline GO & 44 & 479 & 614 & 868 & 1.739 & 3.744 \\
\hline MA & & 362 & 257 & 415 & 628 & 1.662 \\
\hline MG & 199 & 1.269 & 1.897 & 1.032 & 1.591 & 5.988 \\
\hline MS & & & & 304 & 428 & 732 \\
\hline MT & & 60 & 44 & 334 & 407 & 846 \\
\hline PA & 16 & 466 & 412 & 461 & 1.069 & 2.424 \\
\hline PB & & & 43 & & 19 & 62 \\
\hline $\mathrm{PE}$ & & 74 & 263 & 170 & 209 & 716 \\
\hline PR & 109 & 508 & 1.102 & 853 & 2.265 & 4.837 \\
\hline RJ & 2.421 & 4.938 & 3.754 & 2.405 & 3.208 & 16.727 \\
\hline $\mathrm{RN}$ & & 25 & 69 & 312 & 303 & 708 \\
\hline RO & & & 67 & 20 & 54 & 141 \\
\hline RS & 268 & 717 & 921 & 1.393 & 1.565 & 4.863 \\
\hline SC & 5 & 224 & 384 & 220 & 589 & 1.423 \\
\hline SE & & & 30 & & 38 & 68 \\
\hline SP & 7.470 & 19.060 & 17.893 & 11.091 & 18.709 & 74.222 \\
\hline Estados não identificados & 873 & & 907 & 150 & 802 & 2.732 \\
\hline
\end{tabular}


Apêndice D - Segmentação de produtos por empresas

\begin{tabular}{|c|c|c|}
\hline Empresa & Segmento & Preço das unidades \\
\hline \multirow{4}{*}{ Agra } & Econômico & Entre $\mathrm{R} \$ 130 \mathrm{mil}$ e $\mathrm{R} \$ 350 \mathrm{mil}$ \\
\hline & Médio & Entre $R \$ 350 \mathrm{mil}$ e $\mathrm{R} \$ 500 \mathrm{mil}$ \\
\hline & Médio-al to & Entre $\mathrm{R} \$ 500 \mathrm{mil}$ e $\mathrm{R} \$ 1.000 \mathrm{mil}$ \\
\hline & Luxo & acima de $\mathrm{R} \$ 1.000 \mathrm{mil}$ \\
\hline \multirow{3}{*}{ Helbor } & Médio & Entre $\mathrm{R} \$ 350 \mathrm{mil}$ e $\mathrm{R} \$ 500 \mathrm{mil}$ \\
\hline & Médio-al to & entre $\mathrm{R} \$ 500 \mathrm{mil}$ e $\mathrm{R} \$ 1.000 \mathrm{mil}$ \\
\hline & Alto & Acima de $\mathrm{R} \$ 1.000 \mathrm{mil}$ \\
\hline \multirow{5}{*}{ KlabinSegall } & Popular & Inferior a $\mathrm{R} \$ 90 \mathrm{mil}$ \\
\hline & Econômico & Entre $\mathrm{R} \$ 90 \mathrm{mil}$ a $\mathrm{R} \$ 120 \mathrm{mil}$ \\
\hline & Média baixa & Entre $\mathrm{R} \$ 120 \mathrm{mil}$ a $\mathrm{R} \$ 350 \mathrm{mil}$ \\
\hline & Média alta & Acima de $\mathrm{R} \$ 500 \mathrm{mil}$ \\
\hline & Alta & Acima de $\mathrm{R} \$ 500 \mathrm{mil}$ \\
\hline \multirow{5}{*}{ Brookfield } & Econômico & até $\mathrm{R} \$ 130 \mathrm{mil}$ \\
\hline & Média-baixa & Entre $\mathrm{R} \$ 130 \mathrm{mil}$ e $\mathrm{R} \$ 350 \mathrm{mil}$ \\
\hline & Média & Entre $\mathrm{R} \$ 350 \mathrm{mil}$ e $\mathrm{R} \$ 500 \mathrm{mil}$ \\
\hline & Média-alta & Entre $\mathrm{R} \$ 500 \mathrm{mil}$ e $\mathrm{R} \$ 1.000 \mathrm{mil}$ \\
\hline & Alta & acima de $\mathrm{R} \$ 1.000 \mathrm{mil}$ \\
\hline \multirow{6}{*}{ CCDI } & Baixa-renda & Até $\mathrm{R} \$ 100 \mathrm{mil}$ \\
\hline & Econômico & Entre $\mathrm{R} \$ 100 \mathrm{mil}$ e $\mathrm{R} \$ 200 \mathrm{mil}$ \\
\hline & Média & Entre $\mathrm{R} \$ 200 \mathrm{mil}$ e $\mathrm{R} \$ 350 \mathrm{mil}$ \\
\hline & Média-alta & Entre $R \$ 350 \mathrm{mil}$ e $\mathrm{R} \$ 500 \mathrm{mil}$ \\
\hline & Alta & Entre $\mathrm{R} \$ 500 \mathrm{mil}$ e $\mathrm{R} \$ 1.000 \mathrm{mil}$ \\
\hline & Altíssimo & acima de $\mathrm{R} \$ 1.000 \mathrm{mil}$ \\
\hline
\end{tabular}

Pag 1/2 
Apêndice D - Segmentação de produtos por empresas

\begin{tabular}{|c|c|c|}
\hline Empresa & Segmento & Preço das unidades \\
\hline \multirow{5}{*}{ Tenda } & DUO & Até $\mathrm{R} \${ }^{2} 60 \mathrm{mil}$ \\
\hline & Garden & Até $\mathrm{R} \$ \widehat{6} 60 \mathrm{mil}$ \\
\hline & Life & Entre $\mathrm{R} \$ 60 \mathrm{mil}$ e $\mathrm{R} \$ 90 \mathrm{mil}$ \\
\hline & Fit & Entre $\mathrm{R} \$ 90 \mathrm{mil}$ e $\mathrm{R} \$ 130 \mathrm{mil}$ \\
\hline & Tower & Acima de $\mathrm{R} \$ 130 \mathrm{mil}$ \\
\hline \multirow{5}{*}{ Gafisa } & Baixo & Abaixo de $R \$ 130 \mathrm{mil}$ \\
\hline & Econômico & Entre $\mathrm{R} \$ 121$ e $\mathrm{R} \$ 350 \mathrm{mil}$ \\
\hline & Médio & entre $\mathrm{R} \$ 351 \mathrm{mil}$ e $\mathrm{R} \$ 500 \mathrm{mil}$ \\
\hline & Médio-alto & entre $R \$ 501 \mathrm{mil}$ e $\mathrm{R} \$ 1000 \mathrm{mil}$ \\
\hline & Alto & Acima de $R \$ 1.000$ \\
\hline \multirow{4}{*}{ CR2 } & Econômico & Até $\mathrm{R} \$ 130 \mathrm{mil}$ \\
\hline & Média-baixa & Entre $\mathrm{R} \$ 130 \mathrm{mil}$ e $350 \mathrm{mil}$ \\
\hline & Média & entre $\mathrm{R} \$ 351 \mathrm{mil}$ e $\mathrm{R} \$ 500 \mathrm{mil}$ \\
\hline & Alta & Acima de $\mathrm{R} \$ 500 \mathrm{mil}$ \\
\hline \multirow{3}{*}{ MRV } & & Até $\mathrm{R} \$ 80 \mathrm{mil}$ \\
\hline & & Entre $\mathrm{R} \$ 80 \mathrm{mil}$ a $\mathrm{R} \$ 130 \mathrm{mil}$ \\
\hline & & Acima de $\mathrm{R} \$ 130 \mathrm{mil}$ \\
\hline \multirow{3}{*}{ Rodobens } & Moradas & Entre $\mathrm{R} \$ 50 \mathrm{mil}$ a $\mathrm{R} \$ 80 \mathrm{mil}$ \\
\hline & Terra Nova & Entre $\mathrm{R} \$ 75 \mathrm{mil}$ a $\mathrm{R} \$ 150 \mathrm{mil}$ \\
\hline & Sistema Fácil & Acima de $\mathrm{R} \$ 150 \mathrm{mil}$ \\
\hline \multirow{4}{*}{ Rossi } & Até $\mathrm{R} \$ 200 \mathrm{mil}$ & ResidencialRossiAté R\$2 $200 \mathrm{mil}$ \\
\hline & de $R \$ 200,1 \mathrm{mil}$ a $\mathrm{R} \$ 350 \mathrm{mil}$ & Residencialde $\mathrm{R} \$ 200,1 \mathrm{mil}$ a $\mathrm{R} \$ 35$ \\
\hline & de $\mathrm{R} \$ 350,1 \mathrm{mil}$ a $\mathrm{R} \$ 500 \mathrm{mil}$ & Residencialde $\mathrm{R} \$ 350,1 \mathrm{mil}$ a $\mathrm{R} \$ 50$ \\
\hline & Acima de $\mathrm{R} \$ 500,1$ & Residencial Acima de $\mathrm{R} \$ 500,1$ \\
\hline \multirow{4}{*}{ Tecnisa } & Popular & Até $\mathrm{R} \$ 130 \mathrm{mil}$ \\
\hline & Médio-baixo & Entre $\mathrm{R} \$ 130 \mathrm{mil} \mathrm{e} 350 \mathrm{mil}$ \\
\hline & Médio & Entre $\mathrm{R} \$ 350 \mathrm{mil}$ e $500 \mathrm{mil}$ \\
\hline & Alto & acima de $\mathrm{R} \$ 500 \mathrm{mil}$ \\
\hline \multirow{6}{*}{ Even } & Acessível & Entre R\$ $80 \mathrm{mil}$ e $200 \mathrm{mil}$ \\
\hline & Emergente & Entre $\mathrm{R} \$ 200 \mathrm{mil}$ e $350 \mathrm{mil}$ \\
\hline & Médio & Entre $\mathrm{R} \$ 350 \mathrm{mil}$ e $500 \mathrm{mil}$ \\
\hline & Médio-alto & Entre $\mathrm{R} \$ 500 \mathrm{mil}$ e $1.100 \mathrm{mil}$ \\
\hline & Alto & Entre $\mathrm{R} \$ 1.100 \mathrm{mil}$ e $1.600 \mathrm{mil}$ \\
\hline & Alto luxo & Acima de $R \$ 1.600 \mathrm{mil}$ \\
\hline
\end{tabular}

Pag 2/2 
Apêndice F - Alianças Estratégicas identificadas no período 2006-2010

Nas páginas seguintes são apresentadas as aquisições, joint ventures, fusões e parcerias identificadas, por empresa, com os seus objetivos estratégicos então declarados pelas organizações na época da constituição das alianças. 
Apêndice F - Alianças Estratégicas identificadas no período 2006-2010

\begin{tabular}{|c|c|c|c|c|c|c|}
\hline Tipo de aliança & Ano & Empresa & Parceiro & Objetivo declarado & Região-UF & Segmento \\
\hline \multirow{16}{*}{ Aquisição } & 2006 & Cyrela & RJZ Engenharia & Expandir geografia & RJ & \\
\hline & 2007 & PDG & $\mathrm{CHL}$ & Expandir geografia & RJ & \\
\hline & 2007 & PDG & Goldfarb & Expandir segmento de renda & & Econômico e popular \\
\hline & 2007 & PDG & Lindencorp & Expandir geografia & SP Interior & \\
\hline & 2007 & PDG & CIPASA & Expandir geografia & Interior & \\
\hline & 2007 & CCDI & HM Engenharia e construções & Expandir segmento de renda & & Econômico e popular \\
\hline & 2007 & Gafisa & Cipesa & Expandir geografia & AL e SE & \\
\hline & 2007 & MRV & Blás & Expandir geografia & MG e RJ & \\
\hline & 2007 & MRV & Prime & Expandir geografia & BH, GO, DF e Aparecida-SP & \\
\hline & 2008 & Agra & Asacorp & Expandir segmento de renda & & Econômico e popular \\
\hline & 2008 & Brascan/Brookfield & MB Engenharia & Expandir geografia & Centro Oeste & \\
\hline & 2008 & Gafisa & Tenda & Expandir segmento de renda & & Econômico e popular \\
\hline & 2008 & Cyrela & Concima & Expandir segmento de renda & & Econômico e popular \\
\hline & 2008 & JHSF & Developer & Diversificar & $\mathrm{NO}, \mathrm{NE}$ e CO & Econômico e popular \\
\hline & 2009 & Cyrela & Goldstezin & Expandir geografia & Sul & \\
\hline & 2010 & PDG & Ln empreendimentos imobiliários & Expandir geografia & PR e SC & \\
\hline \multirow{12}{*}{ Joint venture } & 2006 & Cyrela & Plano e Plano & Expandir segmento de renda & & Econômico e popular \\
\hline & 2007 & PDG & Fjv & Expandir geografia & BA & \\
\hline & 2007 & Agra & Extrema & Expandir geografia & SP Interior & \\
\hline & 2007 & Gafisa & Odebrecht & Expandir segmento de renda & & Econômico e popular \\
\hline & 2007 & Cyrela & Construtora Lider & Expandir geografia & MG e DF & \\
\hline & 2007 & Cyrela & Cury & Expandir segmento de renda & & Econômico e popular \\
\hline & 2007 & Cyrela & Tecnum & Expandir segmento de renda & & Econômico e popular \\
\hline & 2007 & Cyrela & SKR & Expandir geografia & SP & \\
\hline & 2008 & Cyrela & $\begin{array}{l}\text { Lucio empreendimentos e } \\
\text { participações }\end{array}$ & Expandir geografia & RMSP-SP & \\
\hline & 2008 & Cyrela & Andrade Mendonça & Expandir geografia & BA & \\
\hline & 2010 & Rossi & GMS Construtora & Expandir geografia & MT & \\
\hline & 2010 & Rossi & Toctao & Expandir geografia & GO & \\
\hline
\end{tabular}


Fusões identificadas no período 2006-2010

\begin{tabular}{|c|c|c|c|c|c|c|}
\hline Tipo de aliança & Ano & Empresa & Parceiro & Objetivo declarado & Região-UF & Segmento \\
\hline \multirow{10}{*}{ Fusão } & 2008 & Company & Brascan/Brookfield & $n / a$ & $\mathrm{n} / \mathrm{a}$ & $n / a$ \\
\hline & 2008 & Brascan/Brookfield & Company & $\mathrm{n} / \mathrm{a}$ & $\mathrm{n} / \mathrm{a}$ & $\mathrm{n} / \mathrm{a}$ \\
\hline & 2009 & Klabinsegall & Agra & $\mathrm{n} / \mathrm{a}$ & $\mathrm{n} / \mathrm{a}$ & $\mathrm{n} / \mathrm{a}$ \\
\hline & 2009 & Klabinsegall & Abyara & $\mathrm{n} / \mathrm{a}$ & $\mathrm{n} / \mathrm{a}$ & $\mathrm{n} / \mathrm{a}$ \\
\hline & 2009 & Agra & KlabinSegall & $\mathrm{n} / \mathrm{a}$ & $\mathrm{n} / \mathrm{a}$ & $\mathrm{n} / \mathrm{a}$ \\
\hline & 2009 & Agra & Abyara & $\mathrm{n} / \mathrm{a}$ & $\mathrm{n} / \mathrm{a}$ & $\mathrm{n} / \mathrm{a}$ \\
\hline & 2009 & Abyara & Agra & $\mathrm{n} / \mathrm{a}$ & $\mathrm{n} / \mathrm{a}$ & $\mathrm{n} / \mathrm{a}$ \\
\hline & 2009 & Abyara & KlabinSegall & $\mathrm{n} / \mathrm{a}$ & $\mathrm{n} / \mathrm{a}$ & $\mathrm{n} / \mathrm{a}$ \\
\hline & 2010 & PDG & AGRE & $\mathrm{n} / \mathrm{a}$ & $\mathrm{n} / \mathrm{a}$ & $\mathrm{n} / \mathrm{a}$ \\
\hline & 2010 & AGRE & PDG & $\mathrm{n} / \mathrm{a}$ & $\mathrm{n} / \mathrm{a}$ & $\mathrm{n} / \mathrm{a}$ \\
\hline
\end{tabular}


Parcerias identificadas no período 2006-2010

\begin{tabular}{|c|c|c|c|c|c|c|}
\hline Tipo de aliança & Ano & Empresa & Parceiro & Objetivo declarado & Região-UF & Segmento \\
\hline \multirow{26}{*}{ Parceria } & 2006 & Abyara & Agra & Penetrar mercado & & Negócio principal \\
\hline & 2006 & Abyara & MAC & Penetrar mercado & & Negócio principal \\
\hline & 2006 & Abyara & Setin & Penetrar mercado & & Negócio principal \\
\hline & 2006 & Abyara & Cyrela & Penetrar mercado & & Negócio principal \\
\hline & 2006 & Gafisa & OAS & Expandir geografia & BA & \\
\hline & 2006 & Gafisa & Ivo Rizzo & Expandir geografia & RS & \\
\hline & 2006 & Gafisa & Grupo Marcos & Expandir geografia & GO & \\
\hline & 2006 & Gafisa & Cipesa & Expandir geografia & AL e SE & \\
\hline & 2006 & Gafisa & Proeng & Expandir geografia & ES & \\
\hline & 2006 & Cyrela & Goldfarb & Expandir segmento de renda & & Econômico e popular \\
\hline & 2006 & Cyrela & Concima & Expandir segmento de renda & & Econômico e popular \\
\hline & 2006 & Rossi & Alicerce & Expandir geografia & MG & \\
\hline & 2006 & Rossi & Irmãos thá & Expandir geografia & PR e SC & \\
\hline & 2006 & Rossi & Melnick & Expandir geografia & RS & \\
\hline & 2007 & PDG & Abaurre & Expandir geografia & ES & \\
\hline & 2007 & PDG & Pinto de almeida engenharia & Expandir geografia & RJ-Niterói & \\
\hline & 2007 & PDG & Ln empreendimentos imobiliários & Expandir geografia & PR e SC & \\
\hline & 2007 & PDG & Dominus & Expandir geografia & MG & \\
\hline & 2007 & Klabinsegall & Copema & Expandir geografia & Ribeirão Preto-SP & \\
\hline & 2007 & Klabinsegall & MZM & Expandir segmento de renda & & Econômico e popular \\
\hline & 2007 & Klabinsegall & Habitare & Expandir geografia & MG & \\
\hline & 2007 & Agra & BKO & Expandir geografia & SP e alphaville & \\
\hline & 2007 & Agra & Wrobell & Expandir geografia & RJ & \\
\hline & 2007 & Agra & leal Moreira & Expandir geografia & PA & \\
\hline & 2007 & Agra & Reata & Expandir geografia & CE & \\
\hline & 2007 & Agra & Construtora aliança & Expandir geografia & $A M, A C, R O, R R$ & \\
\hline
\end{tabular}

- Tabela 1 de 3 - 
Continuação da Tabela anterior - Parcerias identificadas no período 2006-2010

\begin{tabular}{|c|c|c|c|c|c|c|}
\hline Tipo de aliança & Ano & Empresa & Parceiro & Objetivo declarado & Região-UF & Segmento \\
\hline \multirow{26}{*}{ Parceria } & 2007 & Abyara & Bueno Netto & Penetrar mercado & & Negócio principal \\
\hline & 2007 & CCDI & Lix da Cunha & Expandir geografia & Campinas-SP & \\
\hline & 2007 & CCDI & Rodobens & Expandir segmento de renda & & Econômico e popular \\
\hline & 2007 & Gafisa & Frarene & Expandir geografia & MA & \\
\hline & 2007 & Gafisa & Planc & Expandir geografia & PB e RN & \\
\hline & 2007 & Gafisa & Bricks & Expandir geografia & CE e PE & \\
\hline & 2007 & Cyrela & Lattini Bertoletti & Expandir segmento de renda & & Econômico e popular \\
\hline & 2007 & Cyrela & Tecco Tecnologia & Expandir segmento de renda & & Econômico e popular \\
\hline & 2007 & Cyrela & Cota emp. imobiliários & Expandir geografia & SC & \\
\hline & 2007 & Cyrela & Santa Izabel & Expandir geografia & São José dos Campos & \\
\hline & 2007 & Cyrela & Incortel & Expandir geografia & ES & \\
\hline & 2007 & Cyrela & Agra & Expandir geografia & MA & \\
\hline & 2007 & Cyrela & EBM construtora & Expandir geografia & GO & \\
\hline & 2007 & MRV & Came & Expandir geografia & RJ & \\
\hline & 2007 & Tecnisa & Artefato engenharia e industria & Expandir geografia & GO e DF & \\
\hline & 2007 & Tecnisa & FR Incorporadora & Expandir geografia & GO e DF & \\
\hline & 2007 & Tecnisa & Tecnopar & Expandir geografia & AM & \\
\hline & 2007 & Tecnisa & DP Engenharia e empreendimentos & Expandir geografia & RMSP & \\
\hline & 2007 & Helbor & Construtora camilloti & Expandir geografia & SC & \\
\hline & 2007 & Eztec & Honduras & Expandir segmento de renda & & Econômico e popular \\
\hline & 2007 & Eztec & Genea & Diversificar & SJC-SP & Econômico e popular \\
\hline & 2007 & Eztec & $M \& M$ & Expandir segmento de renda & & Econômico e popular \\
\hline & 2007 & Eztec & Gafisa & Penetrar mercado & & Negócio principal \\
\hline & 2007 & Eztec & Lindencorp & Penetrar mercado & & Negócio principal \\
\hline & 2007 & Eztec & Trisul & Penetrar mercado & Jundiaí & Negócio principal \\
\hline & 2007 & Even & Inmax & Expandir segmento de renda & & Econômico e popular \\
\hline
\end{tabular}

- Tabela 2 de 3 - 
Continuação da Tabela anterior - Parcerias identificadas no período 2006-2010

\begin{tabular}{|c|c|c|c|c|c|c|}
\hline Tipo de aliança & Ano & Empresa & Parceiro & Objetivo declarado & Região-UF & Segmento \\
\hline \multirow{34}{*}{ Parceria } & 2007 & Even & Brisa & Expandir geografia & $S P$ e $M G$ & \\
\hline & 2007 & Even & Melnick & Expandir geografia & RS & \\
\hline & 2007 & Even & Capuche & Expandir geografia & Nordeste & \\
\hline & 2007 & Rossi & Metron & Expandir geografia & ES & \\
\hline & 2007 & Rossi & Cittá & Expandir geografia & ES & \\
\hline & 2007 & Rossi & Costa Andrade & Expandir geografia & BA & \\
\hline & 2007 & Rossi & Diagonal & Expandir geografia & $\mathrm{RN}$ e CE & \\
\hline & 2008 & PDG & Habiarte Barc & Expandir geografia & Ribeirão Preto-SP & \\
\hline & 2008 & Gafisa & GM Engenharia & Expandir geografia & RO & \\
\hline & 2008 & Cyrela & MAC & Expandir geografia & AM & \\
\hline & 2008 & Cyrela & Doria construtora & Expandir geografia & PR & \\
\hline & 2008 & Rodobens & Grupo Capa & Expandir geografia & RS & \\
\hline & 2008 & Rodobens & Kokplan & Expandir geografia & SC & \\
\hline & 2008 & Rodobens & CCDI & Penetrar mercado & & Negócio principal \\
\hline & 2008 & Tecnisa & Petram & Expandir geografia & BA & \\
\hline & 2008 & Tecnisa & Terra Brasilis & Expandir geografia & $\mathrm{CE}$ & \\
\hline & 2008 & JHSF & Grupo Y & Expandir geografia & PA & \\
\hline & 2008 & Helbor & EBM construtora & Expandir geografia & $\mathrm{GO}, \mathrm{BA}, \mathrm{SP}$ e DF & \\
\hline & 2008 & Even & ARC & Expandir geografia & BA & \\
\hline & 2008 & Even & Construtora pernambuco & Expandir geografia & $\mathrm{PE}$ & \\
\hline & 2008 & Even & Magis & Expandir geografia & $\mathrm{CE}$ & \\
\hline & 2009 & CCDI & Thá Engenharia & Expandir geografia & PR & \\
\hline & 2009 & Tecnisa & Monarco construtora & Expandir geografia & PR & \\
\hline & 2009 & Helbor & Dominus engenharia & Expandir geografia & RJ & \\
\hline & 2009 & Rossi & Marítima & Expandir geografia & DF & \\
\hline & 2009 & Rossi & Capital Construtora & Expandir geografia & AM E PA & \\
\hline & 2010 & PDG & Leal Moreira & Expandir geografia & PA & \\
\hline & 2010 & CCDI & JL Construções & Expandir geografia & PR & \\
\hline & 2010 & CCDI & Kallas Inc. e construções & Expandir geografia & Campinas, São Paulo e Santos & \\
\hline & 2010 & CCDI & Inter Rio Emp. e participações & Expandir geografia & RJ & \\
\hline & 2010 & CCDI & Multipla Engenharia & Expandir geografia & SP & \\
\hline & 2010 & Cyrela & Marquise & Expandir geografia & CE & \\
\hline & 2010 & Helbor & RCA Incorporação e Administração & Expandir geografia & PR & \\
\hline & 2010 & Trisul & Caenge & Expandir geografia & DF & \\
\hline
\end{tabular}

Tabela 3 de 3 
Apêndice G - Lançamentos por empresa

[Em volume estimado de venda - R \$ milhão da base dezembro 2010]

\begin{tabular}{|c|c|c|c|c|c|c|c|}
\hline Empresa & 2005 & 2006 & 2007 & 2008 & 2009 & 2010 & Total geral \\
\hline Abyara & & 110 & 1.225 & 967 & & & 2.302 \\
\hline Agra & 294 & 602 & 1.561 & 1.216 & & & 3.672 \\
\hline Agre & & & & & 1.158 & & 1.158 \\
\hline Brascan & 219 & 353 & 1.106 & & & & 1.678 \\
\hline Brookfield & & & & 2.943 & 2.814 & 2.766 & 8.523 \\
\hline CCDI & 528 & 554 & 1.573 & 1.048 & 584 & 1.392 & 5.678 \\
\hline Company & 174 & 433 & 973 & & & & 1.581 \\
\hline CR2 & & 41 & 614 & 324 & 60 & 112 & 1.150 \\
\hline Cyrela & 1.258 & 2.487 & 3.995 & 3.681 & 4.691 & 5.926 & 22.039 \\
\hline EVEN & 295 & 647 & 1.994 & 1.585 & 982 & 1.528 & 7.032 \\
\hline Eztec & 109 & 339 & 449 & 481 & 536 & 589 & 2.504 \\
\hline Gafisa & 708 & 1.208 & 2.338 & 2.777 & 2.017 & 3.751 & 12.799 \\
\hline Helbor & 250 & 331 & 665 & 638 & 944 & 1.140 & 3.969 \\
\hline Inpar & & 873 & 1.782 & 907 & 150 & 802 & 4.514 \\
\hline JHSF & & 753 & 1.227 & 1.551 & 20 & 1.003 & 4.554 \\
\hline KlabinSegall & 186 & 659 & 1.309 & 1.047 & & & 3.202 \\
\hline MRV & 233 & 412 & 1.404 & 2.798 & 2.738 & 4.604 & 12.190 \\
\hline PDG & 346 & 368 & 1.481 & 2.741 & 1.779 & 6.998 & 13.714 \\
\hline Rodobens & 76 & 110 & 508 & 729 & 681 & 1.112 & 3.216 \\
\hline Rossi & 498 & 1.079 & 2.318 & 2.259 & 2.284 & 3.400 & 11.838 \\
\hline Tecnisa & 324 & 348 & 1.183 & 1.677 & 257 & 2.054 & 5.843 \\
\hline Tenda & 99 & 150 & 2.095 & 1.909 & & & 4.253 \\
\hline Trisul & & & 728 & 766 & 650 & 808 & 2.952 \\
\hline Total geral & 5.598 & 11.857 & 30.530 & 32.045 & 22.346 & 37.984 & 140.360 \\
\hline
\end{tabular}


Apêndice H - Índice de Concentração por Modelo de Negócio

Exposição do portfólio por modelo de negócio para expansão de produtos

\begin{tabular}{|l|c|c|c|c|c|}
\hline \multicolumn{1}{r}{ Empresa } & Aquisição & Desenvolvimento Próprio Joint venture & Parceria & Máximo \\
\hline Abyara & $0 \%$ & $13 \%$ & $0 \%$ & $7 \%$ & $13 \%$ \\
\hline Agra & $11 \%$ & $0 \%$ & $1 \%$ & $5 \%$ & $11 \%$ \\
\hline Agre & $0 \%$ & $46 \%$ & $0 \%$ & $0 \%$ & $46 \%$ \\
\hline Brascan & $0 \%$ & $4 \%$ & $0 \%$ & $0 \%$ & $4 \%$ \\
\hline Brookfield & $0 \%$ & $32 \%$ & $0 \%$ & $0 \%$ & $32 \%$ \\
\hline CCDI & $34 \%$ & $1 \%$ & $0 \%$ & $1 \%$ & $34 \%$ \\
\hline Company & $0 \%$ & $18 \%$ & $0 \%$ & $0 \%$ & $18 \%$ \\
\hline CR2 & $0 \%$ & $0 \%$ & $0 \%$ & $83 \%$ & $83 \%$ \\
\hline Cyrela & $2 \%$ & $9 \%$ & $5 \%$ & $8 \%$ & $9 \%$ \\
\hline EVEN & $0 \%$ & $14 \%$ & $0 \%$ & $0 \%$ & $14 \%$ \\
\hline Eztec & $0 \%$ & $2 \%$ & $0 \%$ & $5 \%$ & $5 \%$ \\
\hline Gafisa & $21 \%$ & $9 \%$ & $0 \%$ & $9 \%$ & $21 \%$ \\
\hline Helbor & $0 \%$ & $8 \%$ & $0 \%$ & $0 \%$ & $8 \%$ \\
\hline Inpar & $0 \%$ & $44 \%$ & $0 \%$ & $5 \%$ & $44 \%$ \\
\hline JHSF & $0 \%$ & $0 \%$ & $0 \%$ & $2 \%$ & $2 \%$ \\
\hline KlabinSegall & $0 \%$ & $13 \%$ & $0 \%$ & $0 \%$ & $13 \%$ \\
\hline PDG & $48 \%$ & $0 \%$ & $0 \%$ & $0 \%$ & $48 \%$ \\
\hline Rossi & $0 \%$ & $29 \%$ & $0 \%$ & $0 \%$ & $29 \%$ \\
\hline Tecnisa & $0 \%$ & $33 \%$ & $0 \%$ & $0 \%$ & $33 \%$ \\
\hline Trisul & $0 \%$ & $44 \%$ & $0 \%$ & $0 \%$ & $44 \%$ \\
\hline
\end{tabular}


Índice de Concentração por Modelo de Negócio

Exposição do portfólio por modelo de negócio para expansão geográfica

\begin{tabular}{|l|c|c|c|c|c|}
\hline \multicolumn{1}{r}{ Empresa } & Aquisição & Desenvolvimento próprio & Joint venture & Parceria & Máximo \\
\hline Abyara & $0 \%$ & $38 \%$ & $0 \%$ & $0 \%$ & $38 \%$ \\
\hline Agra & $0 \%$ & $9 \%$ & $0 \%$ & $0 \%$ & $9 \%$ \\
\hline Agre & $0 \%$ & $47 \%$ & $0 \%$ & $0 \%$ & $47 \%$ \\
\hline Brascan & $0 \%$ & $54 \%$ & $0 \%$ & $0 \%$ & $54 \%$ \\
\hline Brookfield & $19 \%$ & $4 \%$ & $0 \%$ & $1 \%$ & $19 \%$ \\
\hline CCDI & $0 \%$ & $0 \%$ & $0 \%$ & $3 \%$ & $3 \%$ \\
\hline Cyrela & $3 \%$ & $7 \%$ & $8 \%$ & $4 \%$ & $8 \%$ \\
\hline EVEN & $0 \%$ & $2 \%$ & $2 \%$ & $4 \%$ & $4 \%$ \\
\hline Gafisa & $0 \%$ & $2 \%$ & $0 \%$ & $7 \%$ & $7 \%$ \\
\hline Helbor & $0 \%$ & $9 \%$ & $0 \%$ & $12 \%$ & $12 \%$ \\
\hline Inpar & $0 \%$ & $19 \%$ & $0 \%$ & $0 \%$ & $19 \%$ \\
\hline JHSF & $0 \%$ & $0 \%$ & $0 \%$ & $12 \%$ & $12 \%$ \\
\hline KlabinSegall & $0 \%$ & $0 \%$ & $0 \%$ & $4 \%$ & $4 \%$ \\
\hline MRV & $12 \%$ & $44 \%$ & $0 \%$ & $0 \%$ & $44 \%$ \\
\hline PDG & $19 \%$ & $0 \%$ & $1 \%$ & $1 \%$ & $19 \%$ \\
\hline Rodobens & $0 \%$ & $29 \%$ & $0 \%$ & $19 \%$ & $29 \%$ \\
\hline Rossi & $0 \%$ & $8 \%$ & $1 \%$ & $20 \%$ & $20 \%$ \\
\hline Tecnisa & $0 \%$ & $0 \%$ & $0 \%$ & $16 \%$ & $16 \%$ \\
\hline Tenda & $0 \%$ & $49 \%$ & $0 \%$ & $0 \%$ & $49 \%$ \\
\hline Trisul & $0 \%$ & $2 \%$ & $0 \%$ & $1 \%$ & $2 \%$ \\
\hline
\end{tabular}


Apêndice I - Dados financeiros

Receita Bruta Operacional [R \$ mil]

\begin{tabular}{|c|c|c|c|c|c|c|c|}
\hline EMPRESA & 2005 & 2006 & 2007 & 2008 & 2009 & 2010 & $\begin{array}{c}\text { RECEITA } \\
\text { TOTAL 05-10 }\end{array}$ \\
\hline AGRA & $\mathrm{n} / \mathrm{a}$ & 116.068 & 301.926 & 513.515 & $\mathrm{n} / \mathrm{a}$ & $\mathrm{n} / \mathrm{a}$ & 931.509 \\
\hline AGRE & $\mathrm{n} / \mathrm{a}$ & $\mathrm{n} / \mathrm{a}$ & $\mathrm{n} / \mathrm{a}$ & $\mathrm{n} / \mathrm{a}$ & 1.695 .413 & $\mathrm{n} / \mathrm{a}$ & 1.695 .413 \\
\hline BRASCAN & 253.456 & 408.825 & 482.904 & $\mathrm{n} / \mathrm{a}$ & $\mathrm{n} / \mathrm{a}$ & $\mathrm{n} / \mathrm{a}$ & 1.145 .185 \\
\hline COMPANY & 156.420 & 288.628 & 445.199 & $\mathrm{n} / \mathrm{a}$ & $\mathrm{n} / \mathrm{a}$ & $\mathrm{n} / \mathrm{a}$ & 890.247 \\
\hline BROOKFIELD & $\mathrm{n} / \mathrm{a}$ & $\mathrm{n} / \mathrm{a}$ & $\mathrm{n} / \mathrm{a}$ & 792.323 & 1.812 .012 & 3.284 .129 & 5.888 .464 \\
\hline CCDI & 83.800 & 131.103 & 233.522 & 601.409 & 514.073 & 1.028 .844 & 2.592 .751 \\
\hline CR2 & $\mathrm{n} / \mathrm{a}$ & 1.024 & 49.997 & 239.892 & 300.099 & 434.070 & 1.025 .082 \\
\hline CYRELA & 688.848 & 1.116 .681 & 2.079 .441 & 2.847 .441 & 4.087.825 & 4.890 .105 & 15.710.341 \\
\hline EVEN & 78.921 & 215.405 & 442.031 & 827.523 & 1.168 .205 & 1.955 .931 & 4.688.016 \\
\hline EZTEC & 87.294 & 215.405 & 202.399 & 362.392 & 505.978 & 636.397 & 2.009 .865 \\
\hline GAFISA & 517.645 & 728.511 & 1.251 .893 & 1.740 .404 & 3.022 .346 & 3.720 .860 & 10.981 .659 \\
\hline HELBOR & 138.812 & 153.488 & 277.384 & 345.725 & 655.333 & 987.173 & 2.557 .915 \\
\hline JHSF & $\mathrm{n} / \mathrm{a}$ & 133.716 & 315.407 & 675.226 & 496.410 & 762.920 & 2.383 .679 \\
\hline KLABINSEGALL & $\mathrm{n} / \mathrm{a}$ & 144.061 & 255.598 & $\mathrm{n} / \mathrm{a}$ & $\mathrm{n} / \mathrm{a}$ & $\mathrm{n} / \mathrm{a}$ & 399.659 \\
\hline MRV & 111.331 & 104.519 & 456.583 & 1.110 .748 & 1.647 .580 & 3.020 .951 & 6.451 .712 \\
\hline PDG & 439 & 114.312 & 573.573 & 1.231.159 & 1.983 .819 & 5.229 .815 & 9.133 .117 \\
\hline RODOBENS & 44.956 & 49.597 & 129.707 & 403.782 & 466.337 & 705.124 & 1.799 .503 \\
\hline ROSSI & 418.740 & 425.023 & 792.718 & 1.233 .133 & 1.572 .285 & 2.495 .830 & 6.937 .729 \\
\hline TECNISA & 149.670 & 210.745 & 352.132 & 514.069 & 737.197 & 1.415 .218 & 3.379 .031 \\
\hline TENDA & $\mathrm{n} / \mathrm{a}$ & 75.436 & 248.013 & 485.248 & $\mathrm{n} / \mathrm{a}$ & $\mathrm{n} / \mathrm{a}$ & 808.697 \\
\hline TRISUL & $\mathrm{n} / \mathrm{a}$ & $\mathrm{n} / \mathrm{a}$ & 187.990 & 326.948 & 560.184 & 785.896 & 1.861 .018 \\
\hline CONJUNTO DO MERCADO & 2.730 .332 & 4.632 .547 & 9.078 .417 & 14.250.937 & 21.225 .096 & 31.353 .263 & 83.270 .592 \\
\hline
\end{tabular}


Margem Líquida [R \$ mil]

\begin{tabular}{|c|c|c|c|c|c|c|c|}
\hline EMPRESA & 2005 & 2006 & 2007 & 2008 & 2009 & 2010 & $\begin{array}{c}\text { LUCRO } \\
\text { TOTAL 05-10 }\end{array}$ \\
\hline AGRA & $\mathrm{n} / \mathrm{a}$ & 13.257 & 10.024 & 10.523 & $\mathrm{n} / \mathrm{a}$ & $\mathrm{n} / \mathrm{a}$ & 33.804 \\
\hline AGRE & $\mathrm{n} / \mathrm{a}$ & $\mathrm{n} / \mathrm{a}$ & $\mathrm{n} / \mathrm{a}$ & $\mathrm{n} / \mathrm{a}$ & 172.079 & $\mathrm{n} / \mathrm{a}$ & 172.079 \\
\hline BRASCAN & 71.586 & 96.799 & 145.261 & $\mathrm{n} / \mathrm{a}$ & $\mathrm{n} / \mathrm{a}$ & $\mathrm{n} / \mathrm{a}$ & 313.646 \\
\hline COMPANY & 10.431 & 45.482 & 55.253 & $\mathrm{n} / \mathrm{a}$ & $\mathrm{n} / \mathrm{a}$ & $\mathrm{n} / \mathrm{a}$ & 111.166 \\
\hline BROOKFIELD & $\mathrm{n} / \mathrm{a}$ & $\mathrm{n} / \mathrm{a}$ & $\mathrm{n} / \mathrm{a}$ & 102.837 & 201.887 & 363.669 & 668.393 \\
\hline CCDI & 2.700 & 2.398 & -21.282 & 51.753 & 58.007 & 143.195 & 236.771 \\
\hline CR2 & $\mathrm{n} / \mathrm{a}$ & 1.478 & 5.319 & 37.561 & 14.642 & 45.158 & 104.158 \\
\hline CYRELA & 127.801 & 242.283 & 386.761 & 325.541 & 740.398 & 685.066 & 2.507 .850 \\
\hline EVEN & 2.026 & 22.399 & 30.073 & 71.587 & 135.638 & 255.044 & 516.767 \\
\hline EZTEC & 33.086 & 6.737 & 45.922 & 102.156 & 163.191 & 245.462 & 596.554 \\
\hline GAFISA & 27.442 & 44.010 & 91.640 & 244.423 & 142.962 & 439.980 & 990.457 \\
\hline HELBOR & 17.750 & 17.303 & 3.412 & 48.382 & 78.670 & 182.058 & 347.575 \\
\hline JHSF & $\mathrm{n} / \mathrm{a}$ & 52.823 & 53.284 & 151.236 & 155.938 & 213.466 & 626.747 \\
\hline KLABINSEGALL & $\mathrm{n} / \mathrm{a}$ & 2.797 & 27.518 & $\mathrm{n} / \mathrm{a}$ & $\mathrm{n} / \mathrm{a}$ & $\mathrm{n} / \mathrm{a}$ & 30.315 \\
\hline MRV & 23.660 & 12.913 & 42.803 & 251.677 & 374.066 & 634.488 & 1.339 .607 \\
\hline PDG & -634 & 6.030 & 71.157 & 182.463 & 338.132 & 789.552 & 1.386 .700 \\
\hline RODOBENS & 2.461 & 2.365 & 31.387 & 82.818 & 27.770 & 71.653 & 218.454 \\
\hline ROSSI & 20.178 & 43.701 & 73.499 & 118.638 & 203.563 & 349.770 & 809.349 \\
\hline TECNISA & 25.389 & 35.765 & 32.509 & 75.276 & 110.536 & 200.048 & 479.523 \\
\hline TENDA & $\mathrm{n} / \mathrm{a}$ & 4.001 & -7.474 & -38.209 & $\mathrm{n} / \mathrm{a}$ & $\mathrm{n} / \mathrm{a}$ & -41.682 \\
\hline TRISUL & $\mathrm{n} / \mathrm{a}$ & $\mathrm{n} / \mathrm{a}$ & 22.011 & 8.781 & 51.389 & 39.989 & 122.170 \\
\hline CONJUNTO DO MERCADO & 363.876 & 652.541 & 1.099 .077 & 1.827 .443 & 2.968 .868 & 4.658 .598 & 11.570 .403 \\
\hline
\end{tabular}


Patrimônio Líquido [R \$ mil]

\begin{tabular}{|c|c|c|c|c|c|c|}
\hline EMPRESA & 2005 & 2006 & 2007 & 2008 & 2009 & 2010 \\
\hline AGRA & $\mathrm{n} / \mathrm{a}$ & 100.823 & 791.045 & 900.526 & $\mathrm{n} / \mathrm{a}$ & $\mathrm{n} / \mathrm{a}$ \\
\hline AGRE & $\mathrm{n} / \mathrm{a}$ & $\mathrm{n} / \mathrm{a}$ & $\mathrm{n} / \mathrm{a}$ & $\mathrm{n} / \mathrm{a}$ & 1.834 .435 & $\mathrm{n} / \mathrm{a}$ \\
\hline BRASCAN & 91.930 & 1.066 .659 & 1.177 .603 & $\mathrm{n} / \mathrm{a}$ & $\mathrm{n} / \mathrm{a}$ & $\mathrm{n} / \mathrm{a}$ \\
\hline COMPANY & 48.700 & 291.300 & 333.511 & $\mathrm{n} / \mathrm{a}$ & $\mathrm{n} / \mathrm{a}$ & $\mathrm{n} / \mathrm{a}$ \\
\hline BROOKFIELD & $\mathrm{n} / \mathrm{a}$ & $\mathrm{n} / \mathrm{a}$ & 1.177 .603 & 1.514 .780 & 2.417 .256 & 2.701 .894 \\
\hline CCDI & 20.500 & 127.434 & 598.539 & 630.917 & 675.369 & 777.840 \\
\hline CR2 & $\mathrm{n} / \mathrm{a}$ & 62.984 & 360.093 & 378.570 & 379.968 & 431.120 \\
\hline CYRELA & 1.018 .783 & 1.948 .550 & 1.888 .965 & 2.120 .949 & 3.852 .804 & 4.681.937 \\
\hline EVEN & 19.414 & 123.785 & 654.552 & 780.088 & 885.792 & 1.409 .837 \\
\hline EZTEC & 122.449 & 254.337 & 585.250 & 900.525 & 912.673 & 1.116 .642 \\
\hline GAFISA & 300.159 & 814.087 & 1.498 .728 & 1.612 .419 & 2.325 .634 & 3.783 .669 \\
\hline HELBOR & 261.745 & 331.506 & 327.841 & 364.732 & 420.981 & 727.827 \\
\hline JHSF & 62.600 & 104.100 & 778.865 & 869.889 & 932.808 & 1.078 .469 \\
\hline KLABINSEGALL & & 419.418 & 393.452 & 326.674 & $\mathrm{n} / \mathrm{a}$ & $\mathrm{n} / \mathrm{a}$ \\
\hline MRV & 82.539 & 90.637 & 1.367 .773 & 1.551 .761 & 2.392 .920 & 3.052 .750 \\
\hline PDG & 518 & 242.052 & 1.349 .666 & 1.476 .437 & 2.940 .820 & 5.964 .848 \\
\hline RODOBENS & 32.506 & 64.242 & 535.227 & 600.717 & 622.814 & 677.508 \\
\hline ROSSI & 292.648 & 1.079 .677 & 997.742 & 1.238 .372 & 2.283 .413 & 2.522 .358 \\
\hline TECNISA & 113.582 & 141.875 & 760.641 & 794.827 & 880.475 & 1.195 .384 \\
\hline TENDA & 14.445 & 18.387 & 706.078 & 1.062 .214 & 1.130 .898 & 1.710 .208 \\
\hline TRISUL & $\mathrm{n} / \mathrm{a}$ & $\mathrm{n} / \mathrm{a}$ & 445.724 & 420.780 & 462.348 & 508.413 \\
\hline CONJUNTO DO MERCADO & 2.482 .518 & 7.281.853 & 16.728 .898 & 17.545.177 & 25.351 .408 & 32.340 .704 \\
\hline
\end{tabular}

